University of Louisville

ThinkIR: The University of Louisville's Institutional Repository

Electronic Theses and Dissertations

$5-1966$

\title{
The systematics and ecology of the Characeae (Nitella and Chara) of southwestern United States and northern Mexico.
}

Donald R. Tindall

University of Louisville

Follow this and additional works at: https://ir.library.louisville.edu/etd

\section{Recommended Citation}

Tindall, Donald R., "The systematics and ecology of the Characeae (Nitella and Chara) of southwestern United States and northern Mexico." (1966). Electronic Theses and Dissertations. Paper 1443.

https://doi.org/10.18297/etd/1443

This Doctoral Dissertation is brought to you for free and open access by ThinkIR: The University of Louisville's Institutional Repository. It has been accepted for inclusion in Electronic Theses and Dissertations by an authorized administrator of ThinkIR: The University of Louisville's Institutional Repository. This title appears here courtesy of the author, who has retained all other copyrights. For more information, please contact thinkir@louisville.edu. 
UNIVERSITY OF LOUISVILLE

The Systematics and Ecology of the Characeae (Nitella and Chara) of Southwestem

United States and Northern Mexico

\author{
A Dissertation \\ Submitted to the Faculty \\ Of the Graduate School of the University of Louisville \\ In Partial Fulfillment of the \\ Requirernents for the Degree \\ of Doctor of Philosophy
}

Department of Biology

By

Donald R. Tindal 
Name of Student: Donald R. Tindal l

Title of Dissertation: The Systematics and Ecology of the Characeae (Nitella and Chare) of Southwestern United States and Northern Mexico

Approved by the Reading Committee Composed of the Following Members:

Name of Director:

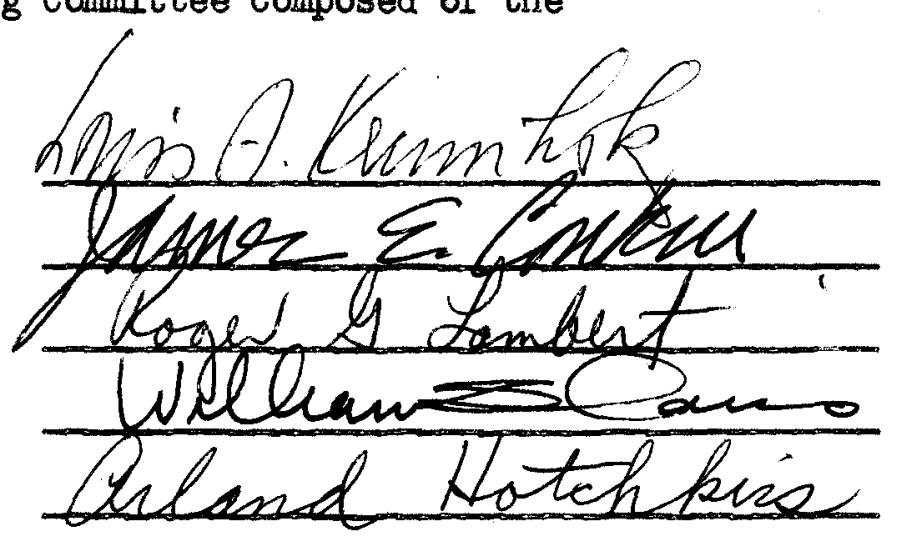

Date: M may 27,1966 


\section{ACKNOWLEDGEMENTS}

The writer gratefully acknowledges $\mathrm{Dr}$. Arland Hotchkiss for his invaluable assistance throughout the course of this study and for his untiring efforts expended toward the preparation of this manuscript. I also wish to express my appreciation to Drs. James E. Conkin, W. Stanley Davis, Louis A. Krumhola, and Roger G. Lambert for their valuable critlcism of the manuscript; to Drs. James E. Craddock and W. L. Minckley for assistance in the field and for collection of specimens during the course of their own research endeavors; to Drs. C. Fred Bryant, Gerald A. Cole, Ioren G. Hill, Melbourne Whiteside, and C. T. Roghson, New York Botanic Garden, for supplying valuable specimens; and to Takashi Sawa for his assistance in all aspects of the study, especially in respect to many stimulating discussions on the Characeae. To my wife, Patricia Manco Tindall, I offer special thanks for encouragement and assistance through all phases of the study. This study was supported in part by National Science Foundation Grants G-13261, G-19449, GB-2698. 
INTRODUCTION $\ldots \ldots \ldots \ldots \ldots \ldots \ldots \ldots \ldots \ldots \ldots \ldots \ldots \ldots \ldots \ldots \ldots \ldots \ldots \ldots$

MATERIALS AND METHODS $\ldots \ldots \ldots \ldots \ldots \ldots \ldots \ldots \ldots \ldots \ldots \ldots \ldots \ldots \ldots \ldots$

KEY TO GENERA OF CHARACEAE ..................... 7 .

KEY TO SPECIES OF NITELLA $\ldots \ldots \ldots \ldots \ldots \ldots \ldots \ldots \ldots \ldots \ldots \ldots \ldots$

NITELLA MISSOURIENSIS $\ldots \ldots \ldots \ldots \ldots \ldots \ldots \ldots \ldots \ldots \ldots \ldots \ldots \ldots \ldots$

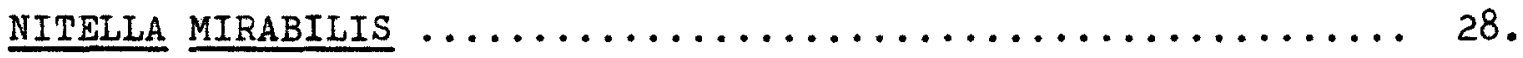

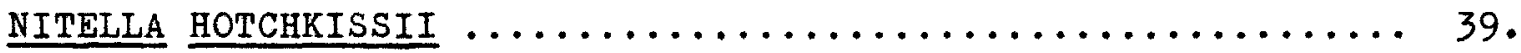

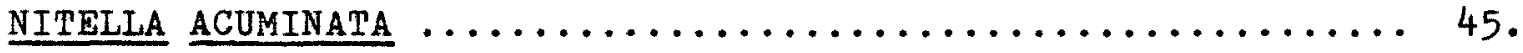

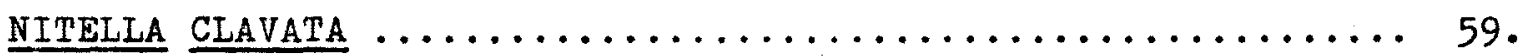

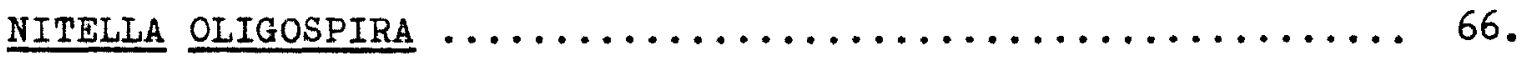

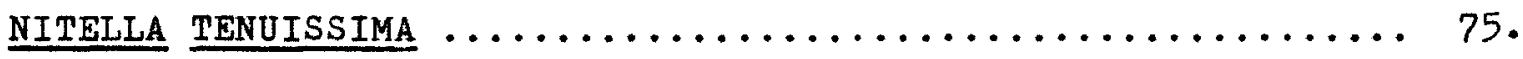

NITELLA GRACILIS SPECIES GROUP ................... 79 .

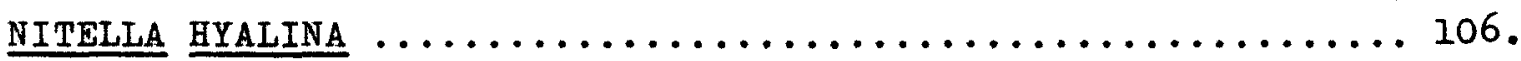

KEY TO SPECIES OF CHARA $\ldots \ldots \ldots \ldots \ldots \ldots \ldots \ldots \ldots \ldots \ldots \ldots \ldots \ldots$

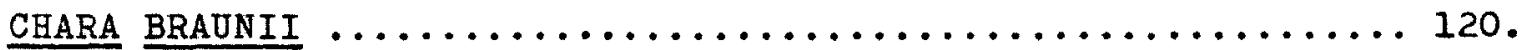

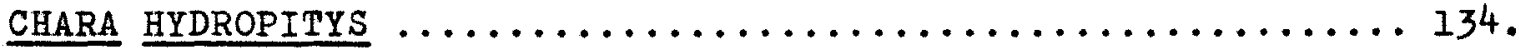

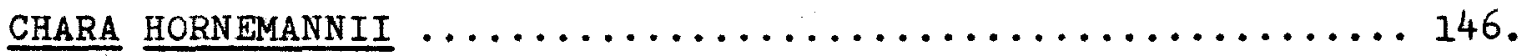

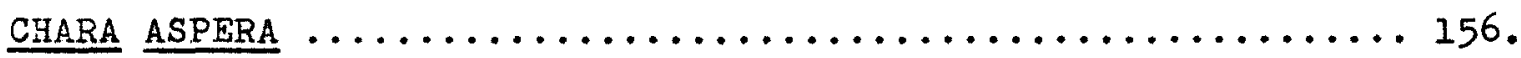

CHARA LEPTOSPERMA $\ldots \ldots \ldots \ldots \ldots \ldots \ldots \ldots \ldots \ldots \ldots \ldots \ldots \ldots \ldots \ldots$

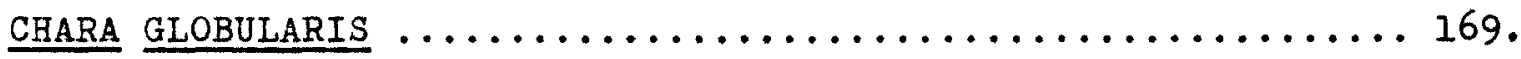

CHARA SEJUNCTA $\ldots \ldots \ldots \ldots \ldots \ldots \ldots \ldots \ldots \ldots \ldots \ldots \ldots \ldots \ldots \ldots \ldots$

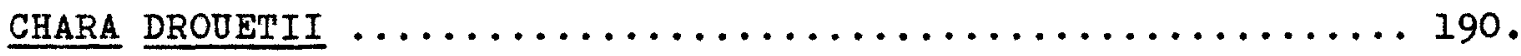

CHARA CIENEGAENSIS $\ldots \ldots \ldots \ldots \ldots \ldots \ldots \ldots \ldots \ldots \ldots \ldots \ldots \ldots \ldots$

SUMMARY AND DISCUSSION ........................ 198 .

LITERATURE CITED ............................ 219.

APPENDIX ................................... 227. 


\section{INTRODUCTION}

General.--The Characeae is the only extant family of an ancient and unique group of nonvascular aquatic plants which are classified as a separate division, the Charophyta (Groves and Bullock-Webster, 1920; Zaneveld, 1940; Imahori, 1954; Bold, 1957; and others) or as a separate class in the Chlorophyta (Fritsch, 1944; Smith, 1950; Wood and Imahori, 1965; and others). Charophytes, like many green algae, are relatively simple haplobiontic plants with zygotic meiosis. However, their complex sexual apparatus, characterized by gametangia enclosed within several sterile cells, distinguishes them from all green algae. The basic morphological features of the genera Nitella and Chara are described and illustrated in this paper. Readily accessible texts which sumarize earlier works on the life history of these plants include Fritsch (1935) and Smith (1950, 1955).

The Characeae is comprised of at least six extant genera, of which Nitella and Chara contribute all but a small percentage of the species. Ancestral forms of Charophyta date back in geologic time to the Devonian, but forms approaching the modern types experienced their greatest prolifferation in the extensive freshwater lakes of the Lower Jurassic (Peck, 1957). Hom af Rantzien (1959) concluded, on the basis of comparative morphology of fossilized fructifications and those of modern forms, that the two main groups of the Characeae (the tribes Nitelleae and Chareae, to which Nitella and Chara belong, respectively) have probably had a long independent history, possibly extending back into the Middle--Upper Jurassic.

Species of Characeae are distributed throughout the world, some occur on every major continent, others are limited to single or adjoining continents, and still others display varying degrees of endemism (Wood and 
Imahori, 1959). The majority of the species occur only in freshwater, whereas some appear to be restricted to brackish waters. Only a few species are capable of inhabiting both fresh and brackish waters. Charophytes are well known as early inhabitants of newly formed ponds, ditches, reservoirs, etc. However, in these new habitats the charophytes may rapidly give way to other aquatic plants. Intermittent pools, ponds, ditches, and margins of lakes characterized by marked fluctuations in water level offer suitable habitat for species capable of withstanding periods of desiccation. Lakes, rivers, and permanent streams appear more suitable for the maintenance of permanent and in some instances perennial populations of charophytes.

Problem.--Although the great plasticity of species of Characeae has been noted by many authors, our understanding of these plants remains based for the most part on descriptions of single specimens with little regard for variation. At the onset of this study our knowledge of the Characeae of Southwestern United States and Mexico was limited to descriptions or mere records of single specimens obtained from various widely scattered habitats. An array of species had been briefly described which drastically needed clarification. No ecological data were available and no distribution patterns had been formulated that could be correlated with such information obtained elsewhere in North America and other continents. Finally, the abundant charophytic flora of this region had not been examined cytologically, a step necessary before final interpretations could be made regarding such studies carried out on charophytes from other areas of North America.

The scope of this study includes (1) collection, (2) determination, and (3) general analysis of variations in morphology as related to taxonomy, ecology, distribution, and chromosome numbers of the species. 
All the species treated here are represented by one or more collections made during the present study. Species previously'recorded from the area but not observed during this study are included only in the keys. In certain cases, species of doubtful taxonomic value are incorporated into other species complexes or are omitted for lack of sufficient data. Specimens from the study area are sometimes compared with those examined from elsewhere in North America. Type specimens of previously established species discussed in the text were not examined but comparisons are made with original descriptions and illustrations. Two of the more complex species groups, Chara vulgaris and ‥ zeylanica (except sejoined types), are treated only briefly in the appendix.

Study area.--Southwestern United States as delimited here includes Oklahoma, Texas, New Mexico, and Arizona (Fig. 1). Areas in northem Mexico examined for charophytes include portions of Tamaulipas, Vera Cruz, Nuevo Ieon, San Iuis Potosi, Coahuila, Chihuahua, Durango, Sonora, and Sinaloa (Fig. 1). Collections and literature records of some species are cited from neighboring states. The study area is characterized by very heterogeneous physiography. Certain types of habitat capable of supporting charophytes have yet to be examined. The major physiographic features and associated limnological characteristics of the American Southwest and Middle America were outlined and discussed by Cole (1963). In the present study the distribution of specimens is correlated only generally with physiographic features. Until a more intensive survey of the area for charophytes is completed, precise correlations can not be made.

Literature.- Published accounts of the Characea from the study area are limited to taxonomic and floristic works. The first major study to 


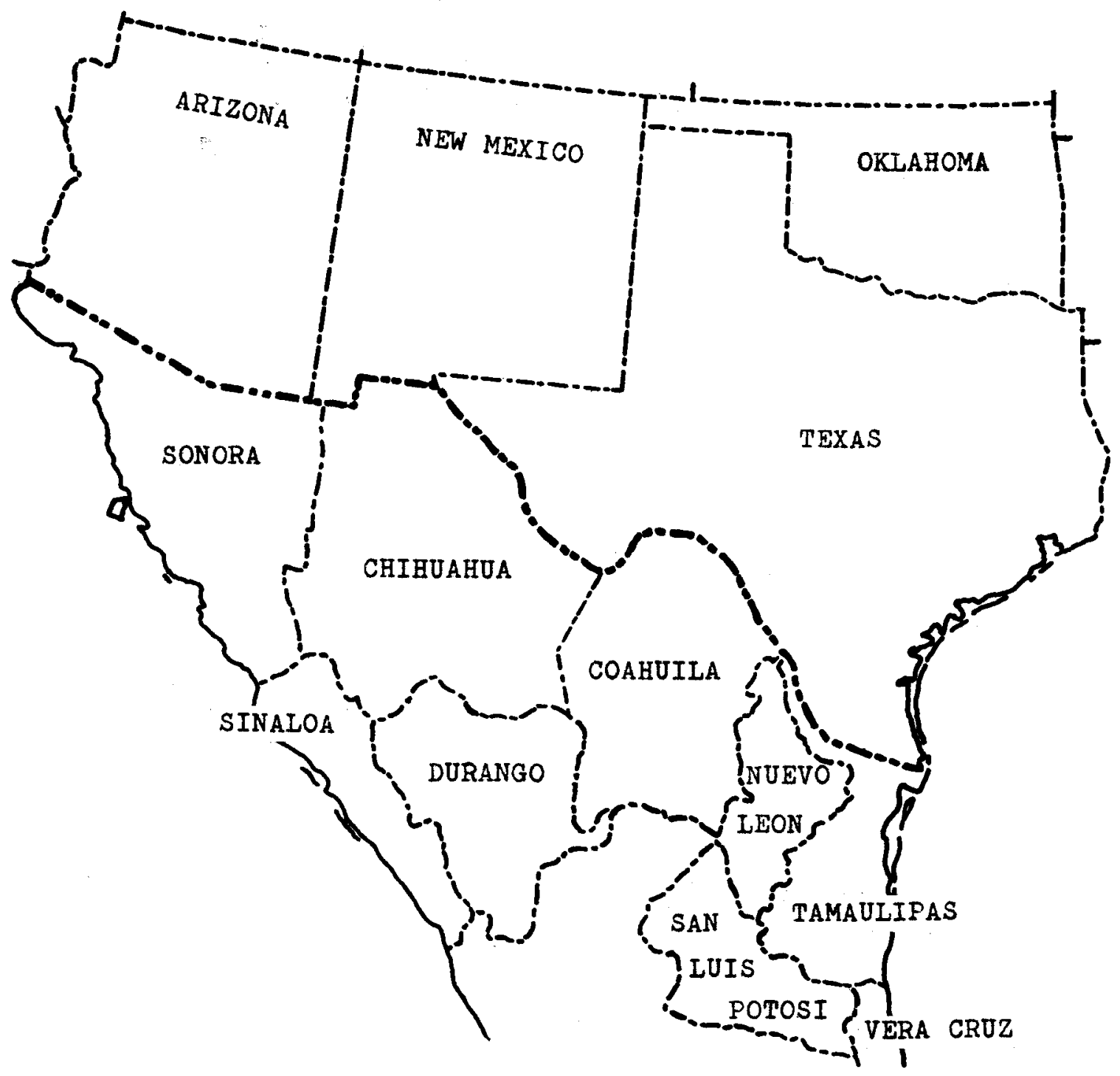

Fig. 1. States of southwestern United States and northern Mexico which comprise the present study area. Specimens are also reported from Arkansas and Kansas. 
include specimens from the area was that of Braun and Nordstedt (1882). In a series of publications Allen (1862, 1888, 1892, 1893a, 1893ㅁ, 1894a, 1894므, 1896a, 1896므, and 1900) reported species of Nitella and Chara, and described several new species of Nitella from the vicinity of or in the study area. Robinson (1906) presented a study of the genus Chara for North America liberal in treatment, in which he described several new species from this area. Zaneveld (1940) discussed many species from the study area in connection with Malaysian charophytes. Wood (1948) presented a complete review of the literature for species of Nitella from North America. A similar study including all species of Characeae reported from Latin America (including Mexico) was presented by Horn af Rantzien (1950). Of considerable importance also is Allen's (1954) list and discussion of the Nitelleae of North America. A complete compilation of specimens and literature for all known Characeae was recently presented in a rather drastic revision of the group (Wood, 1962, 1964; Wood and Imahori, 1964, 1965). Other works conceming charophytes from the study area include Ophel (1952), McCleary (1957), Hevly (1961), Griffin (1963, 1965), Griffin and Proctor (1964), and Cole and Whiteside (1965). The many publications of aquatic biological studies in the area that record charophytes as simply "Chara" have been neglected in the present study. The interpretation of species of Nitella and Chara presented in the present text does not conform precisely with any single taxonomic work cited above. Each one has contributed to the formulation of the treatment presented here. 
Collection and preservation.--Collections of Characeae from the study area were made by the writer in the company of various colleagues (primarily A. T. Hotchkiss and W. L. Minckley) during a series of expeditions: August-September 1960, March-April 1961, September 1961, ApriI 1962, January-February 1963, July-August 1963, and September 1964. Specimens also were received from other biologists working in the area (see ACKNOWLEDGMENTS and citation of specimens). The majority of specimens were collected by hand but a dredge was used for obtaining plants from deep waters. All specimens were preserved in $5 \%$ formalin with traces of copper sulfate, some were mounted on standard herbarium sheets and will be distributed as exsiccatae. Material for cytological examination was fixed in 3:1 absolute ethanol and glacial acetic acid at the time of collection. All specimens examined during this study are housed in the herbarium of the University of Louisville, but distribution to major herbaria is planned.

Morphological observations.-- Examination of external morphological features of mature specimens from the study area involved the measurement and enuneration of most vegetative and reproductive structures. All but the most conspicuous features of the plants were observed microm scopically. The only measurements that require clarification are some of those made on the gametangia and oospores. Oogonial length includes the height of the coronula unless otherwise stated. Measurements of length and width of the oospore do not include flanged ridges or the basal cage. Measurements referred to as D.E.A. in the descriptions and tables represent the distance between the centers of two ridges at the equatorial axis of the oospore.

Cytological observations.--Chromosome numbers were deterrained from 
mitotically dividing antheridial filaments following preparation by the aceto-orcein squash method. All chromosome numbers reported in this paper are haploid and characterize both vegetative and reproductive structures. The oospore apparently is the only diploid phase in the life cycle of these plants.

Ecological observations.-General observations made on the habitats at the time of collection include substrate types, depths at which plants occurred, turbidity, and light conditions. All of these features were only estimated but records of substrate types and water depths are fairly accurate. Waters were recorded as either clear or turbid and light conditions as referred to here simply represent open and/or shaded waters.

Hydrogen ion concentration (expressed as $\mathrm{pH}$ ) was determined with a Beckman, model 180, pocket $\mathrm{pH}$ meter. Total alkalinity (expressed as $\mathrm{mg} / \mathrm{I} \mathrm{CaCO}_{3}$ ) was measured using methyl purple as an indicator and titrating with $0.02 \mathrm{~N}$ sulfuric acid. Total alkalinity is referred to in the text simply as alkalinity. Carbon dioxide content (mg/l) was calculated using $\mathrm{pH}$ and alkalinity data (Moore, 1939). Total chlorides were determined using Hach Chloride Test Powder No. 398 and titrating with $0.02 \mathrm{~N}$ silver nitrate. Temperature measurements were made with a standard centigrade thermometer.

\section{KEI TO GENERA OF CHARACEAE}

The following is a key to the genera of Characeae known to occur in the study area (also North America). Of the four genera included in the key, Nitella and Chara are the only ones treated in the present study. Tolypella has not been reported from the study area but was found during this study to be quite common in March and April in Kansas, Oklahoma, and Texas. One collection was made in Chihuahua, Mexico, by W. L. Minckley, 
May 1964. The only record of Nitellopsis from North America is a single collection of $\mathbb{N}$. bulbillifera Carl de Donterburg reported from New Mexico by Tindall, Sawa, and Hotchkiss (in press).

1a. Branchlets furcate, or monopodial with bilaterally projecting rays, coronula of oogonium consisting of 2 tiers of 5 cells each (Tribe NITELIEAE) • • • • • • • • • • • 2 2a. Branchlets furcate, antheridia terminal at branchlet nodes, oospore laterally compressed. • . . . . . NITELIA

2b. Branchlets monopodial, antheridia lateral at branchlet nodes or at base of whorl, oospore terete . . TOLYPELIA

1b. Branchlets monopodial, divided into segments with whorls of short 1-celled laterals (bract cells and bracteoles) arising from nodes, coronula of oogonium consisting of 1 tier of 5 cells (Tribe CHAREAE). • . . . . . . . . . 3 3a. Axes corticated or uncorticated, stipulodes present . . CHARA 3b. Axes uncorticated, stipulodes absent . . . . NITELLOPSIS KEY TO SPECIES OF NITELLA

The following key includes species of Nitella known to occur in the study area. Species not examined during this study but included in the key are $\mathbb{N}$. praelonga Braun, N. mucronata (Braun) Miquel, N. asagrayana Schaffner ex Nordstedt, N. annularis Allen, and $N$. axillaris Braun. These species have been reported on rare occasions from Texas and/or Mexico. Data on these species were obtained from Wood and Imahori $(1964,1965)$. However, those authors revised each of the above species (see below). The limited number of species occurring in the study area prevent the construction of a completely natural key. The arrangement of species in the key does, however, indicate some general relationships. 
The species examined are similarly arranged in the text. Species reported from the study area that are not included in the key, except N. pygmaea, have been relegated to synonymy (see text).

1a. Branchlets 1-2-furcate, ultimate rays of branchlets 1-celled - 2 2a. Accessory branchlets absent, secondary branchlets present or absent . . . . . . . . . . . . . 3 3a. Plants dioecious, mature antheridia more than $500 \mu$ in diameter

4a. Mature axial internodes less than $1 \mathrm{~mm}$ in diameter coronula of oogoniun deciduous, oospores 225-450 f Iong

5a. Prinary branchlets normally I-furcate; oospores 225-450 $\mathfrak{p}$ long, membrane appearing smooth, finely granulate, or minutely vermiferous, ridges prominent . . . . . . . 6 6a. Axial nodes of fertile heads with $2(-4)$ branches and (1-) $2(-3)$ secondary branchlets each, ultinate rays of primary branchlets $2-3(-4)$, oospores $300-450 \mu$ long. - . . . . . N.miasouriensis

6b. Axial nodes of fertile heads with (3-) $5-7(-8)$ branches and $2-7$ secondary branchlets each, ultimate rays of primary branchlets (2-) 4-6 (7-), oospores 255-315 $\mu$ long . . . . . . N. mirabilis

5b. Primary branchlets 2-furcate; oospores 225$225 \mathfrak{p}$ long, mernbrane spongiform, ridges very inconspicuous . . . . . N. hotchkissii 
4b. Mature axial internodes more than $1.5 \mathrm{~mm}$ in diameter, coronula of oogonjum persistent, oospores $510-620 \mu$ long. . . . . . N. . cemua ${ }^{3}$

3b. Plants monoecious, mature antheridia less than $400 \mu$ in diameter

7a. Plants to $26 \mathrm{~cm}$ high, mature axial internodes less than $1 \mathrm{~mm}$ in diameter, oospores 208-280 $u$ Iong - . . . . . . . . - N. acuminata

7b. Plants sometimes to $200 \mathrm{~cm}$ high, mature axial internodes more than $1500 \mu$ in diameter, oospores

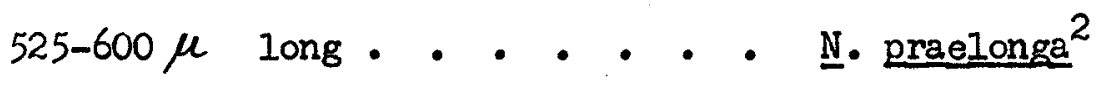

2b. Accessory branchlets present (simple), secondary branchlets absent

1b. Branchlets at least partially 2 (-or more)-furcate, ultimate rays of branchlet 2-or more-celled (including mucro) - . - 8 8a. Accessory branchlets absent - . . . . . . . 9

9a. Branchlets 3-or more-furcate, ultimate rays of branchlets normally elongate, fertile heads not formed . . . 10

10a. Mature axial internodes usually much more than $400 \mu$ in diameter, branchlets normally long and spreading, habit diffuse, antheridia $240-310, \mu$ in diameter, oospore membrane finely reticulate . . . . 11 1la. Oogonia solitary; oospores light brown, 240-280 u long - . . . . . N. oligospira

1 Nitella cernua var. cermua (Braun) Wood. This variety has not been reported from the study area but is know to occur in the West Indies and northern South America (Wood and Imahori, 1965) and may eventually be found in North America. Mexico, southern Texas, and South Carolina (Wood and Imahori, 1965). 
11b. Oogonia usually aggregate; oospores dark brown to nearly black, $256-350 \mu$ long

10b. Mature axial internodes usually much less than $400 \mu$ in diameter, branchlets nomelly short and compact, habit roniliform, antheridia less than $200 \mu$ in diameter, oospore membrane granulate or beaded reticulate • • • • • . • • • . 12 12a. UItimate rays of branchlets strictly 2-celled, mature axial internodes less than $200 \mu$ in diameter, oospores with 5-6 inconspicuous ridges . . . . . . . N. tenuissima

12b. Ultimate rays of branchlets $2-3(-5)$-celled, mature axial internodes more than $200 \mu$ in dlameter, oospores with 7-8 (-9) low but thick ridges (NITELLA GRACILIS SP. GROUP) • . .13 13a. Mucus absent, simple tertiary rays 2-3-celled • . . . - Taxon A 13b. Mucus present, simple tertiary rays usually 3-4-celled . . . . Taxon B

9b. Branchlets 1-2-furcate, some ultimate rays of branchlets characteristically very short forming a crown, fertile heads formed . . . . . . . . . . 14 142. Plants less than $20 \mathrm{~cm}$ high, mature axial internodes less than $500 \mu$ in diameter, oospore membrane densely granulate • • • • • • • • • . 15

3 Nitella furcata ssp. mucronata var. mucronata f. mucronata (Braun) Wood. Reported from southern Texas by Braun and Nordstedt (1882). 
15a. Oltimate rays of sterile branchlets usually short, fertile branchlets 1-2-furcate, oogonia

$1(-2)$ at a node, oospores $275-315 \mu$

long . . . . . . . N. asagrazana 4

15b. Ultimate rays of sterile branchlets usually elongate, fertile branchlets 1-furcate, oogonia 2-3 at a node, oospores $250-285 \mu$ long . . . . . . N. annularis ${ }^{5}$

14b. Plants more than $25 \mathrm{~cm}$ high, mature axial internodes usually much more than $500 \mu$ in diameter, oospore membrane reticulate . . . . N. axillaris 6 8b. Accessory branchlots present . . . . . N. hyalina

4 Nitella gracilis ssp. gloeostachys (Braun) Wood var. asagravana $f$. asagrayana (Schaf mer) Wood. Known only from the type locality near San Luis Potosi, Mexico (Allen, 1896).

5 Nitella gracilis var. asagrazana f. annularis (Allen) Wood. Known only from the type locality in W Chihuahua (Allen, 1894).

6 Nitella translucens ssp. translucens var. axillaris f. axillaris (Braun) Wood. Reported from Mexico (Braun and Nordstedt, 1882). 
NITELLA MISSOURIENSIS AIlen emend. Allen

Figures 2-4

Nitella missouriensis Allen (1892:5).

N. missouriensis emend. G. O. Allen (1954).

N. montana Allen (1892:4).

N. blankinshipii Allen (1892:5).

N. occidentalis Allen (1894:166).

LITERATURE FOR THE STUDY AREA: Allen (1892), Wood (1948), Allen (1954), and Hevly (1961). See also Allen (1894), H. and J. Groves (1911), Horn af Rantzien (1950), Wood (1962), and Wood and Imahori (1964).

DESCRIPTION OF SPECIMENS (including 3 or more shoots from each collection): Plants dioecious (male and female plants similar), (10-) $20-40(-65) \mathrm{cm}$ high, variable in habit but usually rigid with projecting branchlets, not tufted, heads present but similar to expanded whorls, light green to dark green, very lightly to heavily incrusted with lime (in bands). Main axes 600-800 $\mu$ in diameter; internodes on lower parts of plants (4-) 6-8 (-14) cm long, shorter on upper parts. Branchlets not differentiated into fertile and sterile types but tending to form heads when fertile, usually rather straight, rigid and projecting, consistently 8 in a whorl but of two types: PRIMARY BRANCHLETS consistently 6 (very rarely 5 or 7) in a whorl, elongate (sometimes appearing stunted when plants are extremely fertile, especially in upper secondary branches), mature ones quite variable in length, ranging from (ca. 1-) $2-5(-8.5) \mathrm{cm}$ long, 1-furcate; ultimate rays 1-celled, 2-3 (very rarely 4) at a node, very short to ca. $1 / 3$ the length of elongate branchlets, abruptly or gradually acuminate. SBCONDARY BRANCHLETS consistentIy 2 (rarely 1 or 3) in a whorl, occurring opposite secondary branches and slightly below and alternating with primary branchlets, shorter (sometimes 
$-14-$

Figure 2. Nitella missouriensis $(64-9-8-5)$. A. Terminal whorls of branchlets of mature female plant, X 5. B. Range of variation in dactyl apices, X 66. 


$$
\frac{10}{0.00}
$$


Figure 3. Nitella missouriensis. A. Range of variation in dactyl apices $(61-4-4-3 A), X$ 66. B. Dactyl apices $(64-8-30-4), X 66$. C. Terminal whorls of branchlets of mature male plant (MCW 7-30-64), $X$ 5. D. Dactyl apices (MCW 7-30-64), X 66. E. Dactyl apices $(64-9-8-6), \times 66$. 

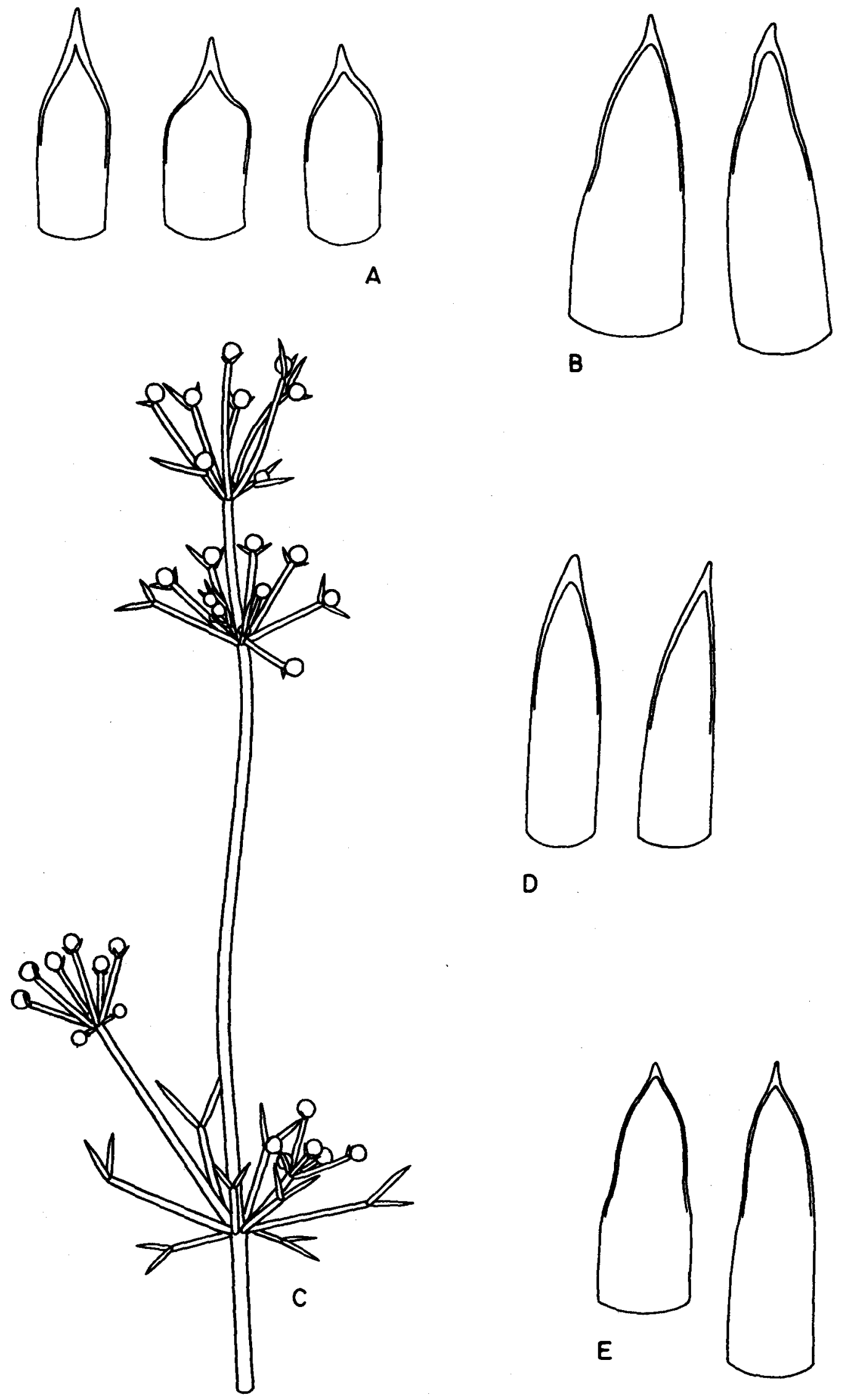
Figure 4. Nitella missouriensis $(62-4-27-2)$. A. Terminal whorls of branchlets of mature male plant, X 5. B. Range of variation in dactyl apices, X 66. 


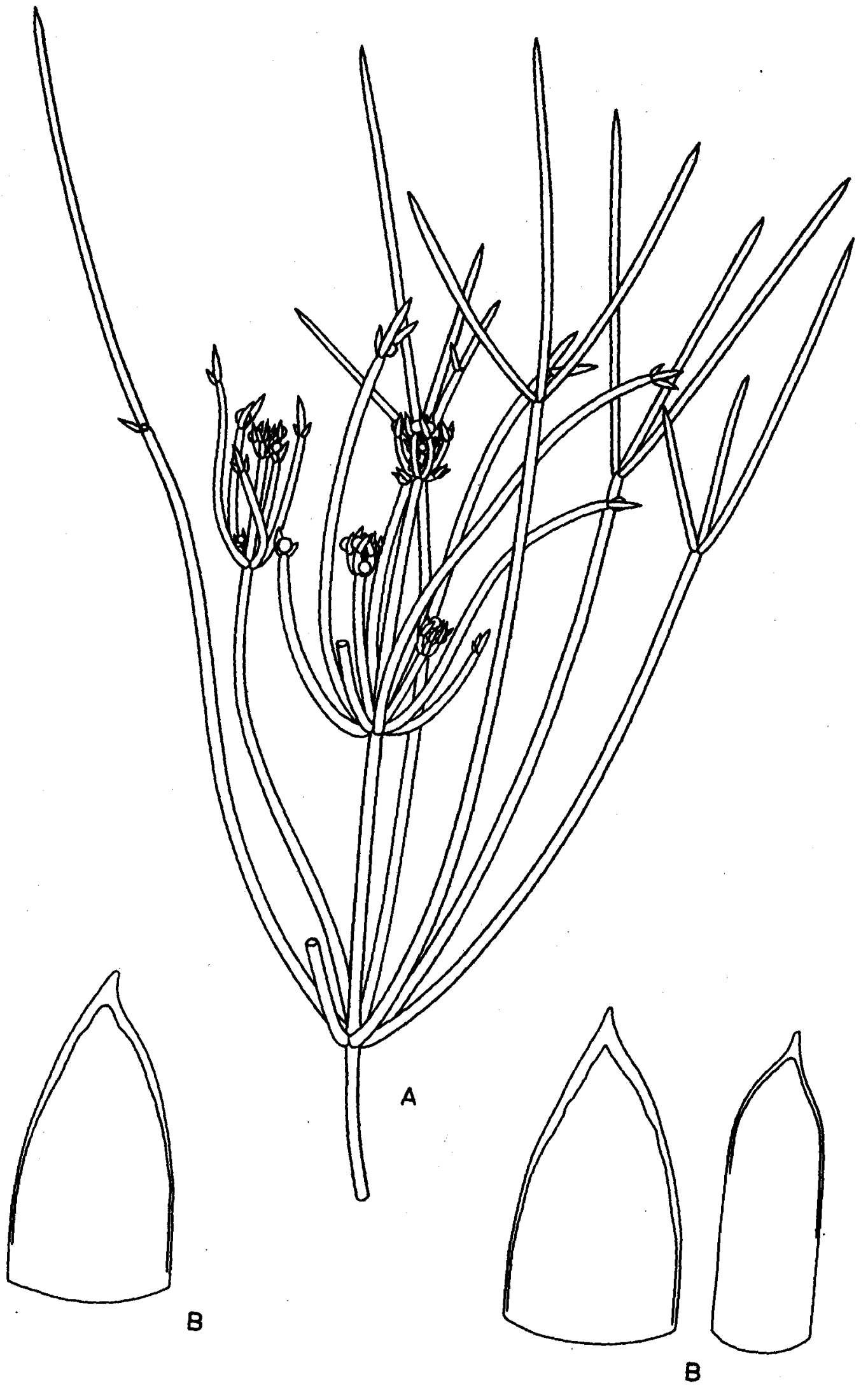


mach shorter) but otherwise similar to primary branchlets. Adventitious branchlets not present. Branches consistently 2 (very rarely 3 or 4 ) at a node. Gametangia--male and female on separate plants, most conspicuous in terminal whorls of the main axes and secondary branches. Oogonia sessile but sometimes appearing to be stalked, (1-) 2-3 (-4) at a branchlet node, 465-675 $\mu$ long (excluding coronula), 385-525 $\mu$ wide; coronula deciduous $40-58 \mu$ high, 76-90 $\mu$ wide. Oospores medium brown to dark brown, $300-450 \mu$ long, $255-375 \mu$ wide; striae of $6(-7)$ prominent ridges; D.E.A. 54-83 $\mu$; membrane minutely vermiferous, appearing finely granulate under low magnification, sometimes displaying a markedly roughened coating which adheres to the outer wall with varying degrees of persistency. Antheridia solitary and sessile at branchlet nodes, sometimes appearing to be aggregate on a short stalk but are actually solitary at branchlet nodes of a fully formed but very short secondary branch, 675-945 $\mu$ in diameter, 8-scutate.

SPBCIMENS EXANINED: KANSAS: (62-4-26-3A) Shallow pool, Marais des Cygnes Waterfowl Refuge, Area D, Ijm Co., Kansas, D. Tindall, A. Hotchkiss, and W. Mincklex, April 26, 1962. (62-4-27-2) Roadside pond, U. S. Hwy. 166, 5.5 mi. E Caney, Montgomery Co., Kansas, D. Tindall, A. Hotchkiss, and W. Minckley, April 27, 1962.

OKLAHOMA: (62-4-29-9) Shallow Pond (Kiamachi Mts.), $1.7 \mathrm{mi}$. S. Snow, U. S. Hwy. 271, Pushmataha Co., Oklahoma, D. Tindall, A. Hotchkiss, and W. Kinckley, April 29, 1962.

TEXAS: (61-4-1-3) Cnion Creek, SSR Austin, near Bergstrom Air Base, Travies Co., Texas, D. Tindall, W. Minckley, and J. Craddock, April 1, 1961. (61-4-1-5 tent. det.) Near bank, San Marcos Spring, I San Karcos, Hays Co., Texas, D. Tindall, W. Minckley, and J. Craddock, April 1, 1961. (61-4-4-3A) Rio Frio, below Jpper Camp Area, Garner 
Mtate Park, N Garner, Uralde Co,, Texas, D. Tindall and W. Hinckley, Apt11 4, 1961.

ARIZONA: (64-8-30-4 and 64-8-30-5) Large spring fed lake, $1 \mathrm{mi}$. I Vernon intersection, U. S. Hing 60, Apache Co., Arizona, D. Tindall and A. Hotchkiss, Aug. 30, 1964. $(64-9-8-6)$ Wilson Lake" (deep earthen tank), 11 mi. W Green Jat., State Hwy 73, Apache Co., Arizona, D. Tindall and A. Hotchldiss, Sopt. 8, 1964. (64-9-8-5) Apache Core Lake, off State Hwy 173, $1 \mathrm{mi}$. N Lakeside, Havajo Co., Arizona, D. Tindall and A. Hotehkiss, Sept. 8, 1964. (64-9-7-1) Small earthen tank, I side of State thry 79, just S Schnebly Hill Road Intersection (ca. 15 mi. S Flagsteff), Coconine Co., Arizese, D. Tindall and A. Hotchkiss, Sept. 7, 1964. (MCW 7-29-64) Upper Hesl Spring, at Jet. of Cape Royal and Point Imperial roads, North Rim of Grand Canyon, Coconino Co., Arlzona, K. C. Whiteside, July 29, 1964. (HCW 7-30-64) Small sink, 2 mi, N Iittle Pleasant Valley Lake, North Rin of Grand Canyon, Coconino Co., Artzona, H. C. Whiteside, July 30, 1964.

CHIHLAHUA: (WI 939-A) Small dryiag poel of Rio Samta Karia, 5.8 mi. W, 1 mi. N Galeana, Chihuahua, Mexico, W. Minckley, Lay 29, 1964. TYPE LOCALITI: Springfield, Lissouri (AIlen, 1892).

DISTRIBUTION: Nitella migsouriengis s. at. and N. blankinshipii are known only from their respeetire type localities in Kissouri (Allen, 1892). The known distribution of II. matann is limited to the two localities in Montana cited in the original description (Allen, loc. cit). Pitella eccidentalis was deseribed from a single collection from Lake Comty, Californin but plants included moder that name were recorded from the West Indies (H. and J. Groves, 1911). Following the broad tinterpretation of the species auggested by H. and J. Groves (Ioc. eit.) and form lly presented by Allon (1954), F. K. Dasly (in Hevly, 1961) 
Identified N. missouriensis from three localities in Arlzona (Hevly \& Haskell, Schultz Pass cattlo tank, San Francisco Peaks, Coconino County, Juno 29, 1958; Herly \& Haskell. Crescent and Big Lakes, Apache County, July 12-15, 1958).

The known distribution of Nitella missouriensis in or near the study are is included in Figure 5. The species is doubtlessly more widely distributed than is indicatod by the present collections, but In the study area the species population appears to be physiographically separated into two distinct segments. The species appears to be a vernal form in south-central United States, whereas it is a common summer form in the western highlands. The localities of the species in central United States were observed in marginal areas of regions with higher olevations, namely the Ozark Plateau in Missouri and Oklahoma, and the Edwards Plateau in Texas.

BCOLOFY: Physicochemical fentures of the habitats-Various data from habitats supporting Nitella missouriensis are included in Table 1. These data show a relatively wide range of environmental conditions associated with the species but more precise sampling may have revealed somewha: different results. The species was seldom observed in any great abundance, but the most extensive stands occurred in habitats charactorized by silty substrates and cool moderately alkaline waters. The largest specimens examined were taken from deep or heavily shaded bodies of water. The species occurred in waters lacking free carbon dioxide, but in each instance the plants were quite mature and covered with a heary eptphytic flora, and appeared to be dying. This was especially ovident in the single Oklahoma locality found to support the species :

Plant cammunities.-Nitella missouriensis was observed on one occasion in association with the closely related N. mirabilis (pond, 


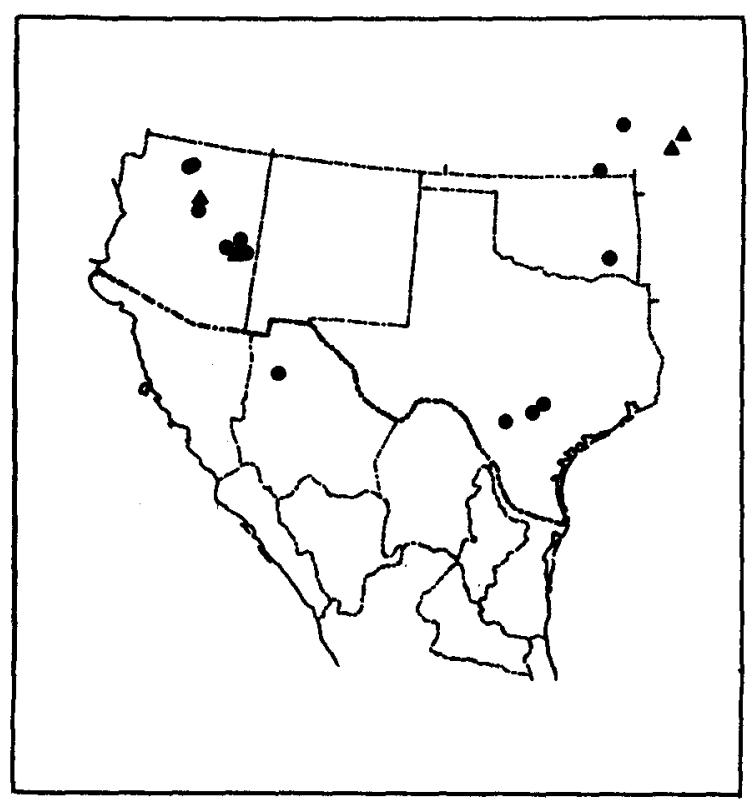

Fig. 5. Distribution of Nitella missouriensis in the study area; localities examined during the present study, A localities reported in the literature. 
Table 1. Fhyicoohemical features of habitats supporting Nitella missouriensis. *

\begin{tabular}{|c|c|c|c|c|c|c|c|c|c|c|c|}
\hline Specimens & Locality & Habi tat & Subs trate & $\begin{array}{l}\text { Depth } \\
\text { (m) }\end{array}$ & $\begin{array}{l}\text { Tur- } \\
\text { bidi ty }\end{array}$ & Light & $\begin{array}{l}\text { Tempe } \\
\text { air }\end{array}$ & $\begin{array}{l}\text { rature } \\
\text { water }\end{array}$ & $\mathrm{pH}$ & Alk. & $\mathrm{CO}_{2}$ \\
\hline $62-4-26-3 k$ & Kansas & small pond & silt & $0.15-0.2$ & 4 & open & 31.0 & 28.0 & 7.4 & 167 & 12.5 \\
\hline $62-4-27-2$ & Kansas & small pond & $\begin{array}{l}\text { silt- } \\
\text { organic }\end{array}$ & $0.30-0.6$ & 0 & shaded & 22.0 & 17.0 & 7.5 & 164 & 9.5 \\
\hline $62-4-29-9$ & Oklahoma & small pond & silt & $0.15-0.3$ & + & open & 29.5 & 27.0 & 8.5 & 27 & 0.0 \\
\hline $64-8-30-4$ & Artzona & $\begin{array}{l}\text { spring-fed } \\
\text { lake }\end{array}$ & $\begin{array}{l}\text { mud-sand- } \\
\text { silt }\end{array}$ & $0.20-0.3$ & 0 & $\begin{array}{l}\text { open \& } \\
\text { shaded }\end{array}$ & 26.0 & 16.0 & 7.5 & 102 & 6.0 \\
\hline $64-9-8-6$ & Arizona & large tank & mud-sand & $2.00-3.0$ & + & open & $\begin{array}{l}24.0 \\
\text { (sur }\end{array}$ & $\begin{array}{r}22.0 \\
\text { faco) }\end{array}$ & 9.0 & 45 & 0.0 \\
\hline $64-9-8-5$ & Arizona & large tank & $\begin{array}{l}\text { mud-sand- } \\
\text { silt }\end{array}$ & $0.30-0.4$ & + & open & 26.5 & 24.5 & 8.2 & 129 & 1.0 \\
\hline $64-9-7-1$ & Arizona & small tank & $\begin{array}{l}\text { sand-mud- } \\
\text { silt }\end{array}$ & $0.15-1.0$ & 0 & open & 23.0 & 20.0 & 7.85 & 109 & 2.0 \\
\hline uCW 7-29-64 & Arizona & $\begin{array}{l}\text { spring-fed } \\
\text { pool }\end{array}$ & & & & & & 20.0 & 8.8 & & \\
\hline 1W 7-30-64 & Arizona & pond & & shallow & & & & 19.4 & 7.2 & & \\
\hline
\end{tabular}

* See materials and methods for further explanation of ecological tables. 
Iinn Co., Kansas, 62-4-26-3A). The small (heavily shaded) pond in Montgomery County, Kansas $(62-4-27-2)$, supported a small population of well developed N. missouriensis. A small adjoining pond supported a luxuriant stand of Chara contraria. Nitella missouriensis was the only attached plant recorded from the pond in Pushmataha County, Oklahoma (62-4-29-9), however, a massive growth of epiphytes nearly covered the Nitella. A single sterile plant of $\underline{N}$. missouriensis was observed alongside a single plant of Chara braunii in San Marcos Spring (Hays Co., Texas, 61-4-1-5). The respective sections of Onion Creek (Travies Co., Texas, 61-4-1-3) and the Rio Frio (Uvalde Co., Texas) examined during this study supported only a few sterile plants of Nitella missouriensis in association with rather large stands of $\mathbb{N}$. gracilis and Chara contraria.

In the Westerm Highlands, Nitella missouriensis most frequently occurred as a minor element of a rather extensive stand of charophytes. The spring-fed lake in Apache County, Arizona (64-8-30-4), supported a dense zone of charophytes composed principally of Chara braunii but also contained scattered isolated plants or tufts of C. globularis, Nitella clavata, and N. missouriensis. The distribution of the latter species in the zone was distinctly associated with small pockets of cool water. These pockets apparently were areas of groundwater seepage. A similar association, excluding N. clavata, was observed in the small earthen tank in Coconino County, Arizona (64-9-7-1). However, there was a mixed association of more or less equal amounts of Chara braunif

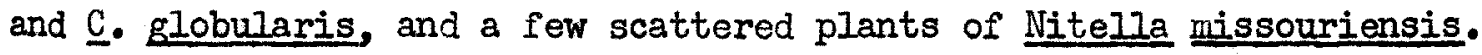
Apache Cove Lake (Navajo Co., Arizona, 64-9-8-5) displayed a similar association but contained $\underline{N}$. clavata in place of Chara braunij. The three species occurred as small monospecific tufts randomly distributed in the shallow waters around the northerm edge of the lake. W. Minckley 
collected C. Blobularis and Nitella missouriensis in a small drying pool of the Rio Santa Maria (Chihuahua, Mexico, WM 939-A). The most oxtensive stand of $\underline{N}$. missouriensis was observed in Wilson Lake (Apache Co., Arizona, 64-9-8-6). The spectes formed a rather dense bed in the deeper central part of the lake. Blodea camadensis formed a dense zome in the shallower waters around the entire lake. Nitella missouriensis occurred in association with Potamogeton sp. in the two localities in Coconino County, Arizona examined by M. C. Whiteside. MORPHOLOGY, CYTOLOGY, AND TAXONOMY: Specimens of Nitella missouriensis examined during this study were very consistent in respect to number and character of branchlets, dactyls, and secondary branches. Marked variations were observed only in relative size of these structures (Figs. 2-4). Such variation appeared to be correlated with environmental conditions. Plants from deep or heavily shaded waters were taller and more robust than those from shallower well-lighted waters. Plants occurring in the latter situation were usually quite compact and more fertile than those from deep or shaded waters.

Considerable variation in size of mature gametangia and oospores was observed among the specimens collected during this study (Table 2). The most extreme variation in oospore size was observed in collection 62-4-29-9 from Oklahoma. The size and shape of oospores from those specimens closely paralleled that recorded for N. mirabilis (Table 4) but the specimens displayed a very distinct $\underline{N}$. missouriensis regetative character. There is a possibility, based on distribution and morphology, that these specimens represent 2 hybrid between the two species. However, the range of variation in gametangia and oospores in other collections of N. missouriensis prevents such a conclusion at this time.

The marked variation in size of antheridia appears to be of little 
Table 2. Comparison of gemetangia and oospores of various specimens representing Mitella missouriensis: (A) present 8 tudy, (B) li terature. *

\begin{tabular}{|c|c|c|c|c|c|c|c|c|c|c|}
\hline SPECINAHS & & $\begin{array}{l}\text { OOGONIA } \\
\text { length }\end{array}$ & width & $\begin{array}{l}\text { CORONUL } \\
\text { height }\end{array}$ & width & $\begin{array}{l}\text { OOSPORES } \\
\text { leng th }\end{array}$ & width & rídges & D.E.A. & $\begin{array}{l}\text { AN THERIDIA } \\
\text { diame tor }\end{array}$ \\
\hline $62-4-29-9$ & $\begin{array}{l}\mathbf{H} \\
\mathbf{R} \\
\mathbf{Y}\end{array}$ & $\begin{array}{l}2 \\
465-495\end{array}$ & $385-405$ & & - & $\begin{array}{l}2 \\
300-325\end{array}$ & $255-270$ & 6 & $54-67$ & $\begin{array}{l}14 \\
675-780 \\
723 \pm 7.4\end{array}$ \\
\hline $64-8-30-4$ & $\begin{array}{l}\mathbf{N} \\
\mathbf{R} \\
\mathbf{Y}\end{array}$ & $\begin{array}{l}3 \\
495-525\end{array}$ & $425-455$ & $\begin{array}{l}1 \\
43\end{array}$ & 76 & $\begin{array}{l}15 \\
315-350 \\
334 \pm 2.6\end{array}$ & $\begin{array}{l}300-350 \\
320 \geq 3.9\end{array}$ & $6-7$ & $\begin{array}{l}54-65 \\
60 \div 1.1\end{array}$ & $\begin{array}{l}15 \\
735-900 \\
823+12.2\end{array}$ \\
\hline $61-4-1-3$ & $\begin{array}{l}\mathbf{N} \\
\mathbf{R}\end{array}$ & & & & & $1_{420}^{\text {germine }}$ & $\begin{array}{c}\text { ted oos pore } \\
345\end{array}$ & 7 & 63 & \\
\hline MCH 7-30-64 & $\begin{array}{l}\mathbf{H} \\
\mathbf{R} \\
\mathbf{u}\end{array}$ & $\begin{array}{l}5 \\
555-615 \\
583 \pm 12.8\end{array}$ & $\begin{array}{l}480-525 \\
504 \pm 11.4\end{array}$ & $\begin{array}{l}47-58 \\
52 \pm 5.4\end{array}$ & $\begin{array}{l}83-90 \\
87+2.5\end{array}$ & $\begin{array}{l}15 \\
315-390 \\
365+5.1\end{array}$ & $\begin{array}{l}295-375 \\
339 \pm 5.3\end{array}$ & $6-7$ & $\begin{array}{l}58-72 \\
66 \pm 1.3\end{array}$ & $\begin{array}{l}15 \\
860-945 \\
915 \pm 8.2\end{array}$ \\
\hline $64-9-7-1$ & $\mathbf{y}$ & & & & & $\begin{array}{l}1 \text { germine } \\
375\end{array}$ & $\begin{array}{l}\text { tod oos pore } \\
345\end{array}$ & 6 & 79 & \\
\hline $64-9-8-5$ & $\mathbf{H}$ & & & & & $\begin{array}{l}1 \text { germine } \\
435\end{array}$ & $\begin{array}{c}\text { tod oos pore } \\
375\end{array}$ & 6 & 83 & \\
\hline $64-9-8-6$ & $\begin{array}{l}\mathbf{H} \\
\mathbf{R} \\
\mathbf{H}\end{array}$ & $\begin{array}{l}10 \\
630-675 \\
655 \pm 5.3\end{array}$ & $\begin{array}{l}480-525 \\
511 \pm 5.3\end{array}$ & $\begin{array}{l}1 \\
40\end{array}$ & 79 & $\begin{array}{l}15 \\
405-450 \\
428 \pm 3.0\end{array}$ & $\begin{array}{l}330-390 \\
365 \$ 5.9\end{array}$ & $6-7$ & $\begin{array}{l}65-79 \\
70 \pm 1+2\end{array}$ & $\begin{array}{l}15 \\
690-870 \\
782 \pm 13.8\end{array}$ \\
\hline
\end{tabular}


Pable 2. oontinued

B II Hssourensis

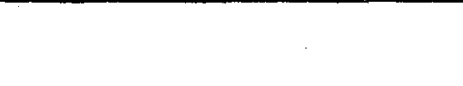

N. montana

-(AIIen, I892)

N. montana N. montana Imahori, 1964)

465-525 420-480

N. blankinshipii (AI10n, 1892)

N. blankinshipii $\quad 620-680$ (Tood \& Imahori, 1964)

IN. ocoidentalis

(1)
(IIIen, 1894)

N. occidentalis $\quad 450-510 \quad 330-450$ -(rood \& Imahori, 1964)

$535-560$

$42-45$

70-87

$390-450$ in diam.

$50-66$

450-525

800

$345-390 \quad 320-365 \quad 6 \quad-$

73

$600-750$

- Measurements are in microns unless otherwise indieated (in all tables of morphological features). 
significance. AII mature specimens of N. gissouriensis and its close relatives examined during this study displayed antheridia with diameters ranging from a few microns to the maximums recorded in Table 2. The measurements included in the table represent only the larger and distinctly nature antheridia. It was quite apparent, however, that even omaller ones were mature or capable of maturing without appreciable increase in size. Environmental conditions appear to be of jor importanee with regard to the maximum size that antheridia will attain within a particular population, thus resulting in considerable variation in this character throughout the range of the species. This degree of variation in antheridial size is limited primarily to species of the 1. missourzensis type.

A chromosome number of 6 was determined for specimens from collections $62-4-26-34,62-4-27-2,62-4-29-9,64-8-30-4,64-9-7-1$, 64-9-8-5, and 64-9-8-6. The chromosome number of Nitella missouriensis has not been published but a chromosome number of 6 has been reported for some closely related dioecious species (N. opaca, Gillet, 1959; Hotchkiss, 1963; N. Syncarpa, Gillet, 1959; N. mirabilis, Sarma and Khan, 1964; present study; and N. Inokashiraensis, Kasaki, 1964).

Allen (1954) concluded that specimens described as Nitella missouriensis, N. montana, N. blankinshipii, and N. occidentalis constitute a single species which should retain the name N. missouriensis. Such a treatment was suggested by H. and J. Groves (1911) but they maintained the separation of the species at that time. The present study confirms Allen's conclusion in that the variations between the descriptions of the above forms are encompassed by the range of variation displayed by the present specimens. This is evident in both sexual and vegetative characteristics. 
descriptions of the four species discussed above and further measurements from representative or type specimens of these forms reported by Wood and Imahort (1964) are included in Table 2. The complete range in size of oogonia and oospores for these forms is similar to that observed in the present specimens. The ranges in diameter of antheridia previously reported for the species is generally smaller than those of the present specimens; however, these differences can be overlooked, because of the known varlability existing in this type of Nitella.

Although It is concluded that ‥ missouriensis s. st., N. montana, N. blankinshipil, N. occidentalis, and the specimens of this type examined during the present study represent a single species retaining the name N. missouriensis, the entire complex shows a close similarity to N. opaca which has been reported from a few localities in and near the study area. It is not known whether or not these records represent typical N. opaca or forms similar to N. missouriensis. In any case, there exists a distinct possibility that the present form represents merely in infraspecific taxon within the N. opaca complex. 
NITEILA MIRABIIIS Nordstedt ex Croves

\section{Figures 6-8}

Nitella mirabilis Nordstedt ex J. Groves (1924:364).

DESCRIPTION OF SPBCDENS (including 5 or more complete shoots from each collection): Plants dioecious (male and female plants similar), (12-) 20-30 (-45) $\mathrm{cm}$ high, with distinct terminal and axillary heads composed of numerous reduced secondary branches and primary, secondary, and adventitious branchlets, single plants forming rather dense tufts, medium green to rather dull but dark green, with or without mucus in fertile heads (most apparent on male plants, lacking on mature female plants), very lightly to moderately incrusted with lime. Main axes $450-900 \boldsymbol{p}$ in diameter; internodes to $8 \mathrm{~cm}$ long, as long as or longer than branchlets on lower parts of plants but mach shorter than branchlets on upper parts of plants. Branchlets not differentiated Into fertile and sterile types but occurring as elongate and contracted ones, the latter forming compact or loose (when mature) head. which are usually very fertile, totaling 6-13 in a whorl but of two general types: PRIMARY BRANCHLETS basically 6 but ranging from 5-9 in a whorl, the higher numbers being characteristic of heads, from a few $\mathrm{mm}$ (in heads) to $6.5 \mathrm{~cm}$ (in expanded whorls) long; 1(-2)-furcate; ultimate rays 1-celled, (2-) 4-6 (-7) at a node, 1/4-1/2 branchlet length in elongate whorls, blunt, acute, or tending to be acuminate. SECONDARY BRANCHLETS 2-7 in a whorl, most numerous in heads, occurring opposite secondary branches and slightly below and alternating with primary branchlets, shorter than associated primary branchlets, 1-furcate into $2-3(-4)$ ultimate rays, superficially appearing as short stalks supporting gametangia (these frequently have 2 or more minute dactyls). Adventitious branchlets comon in heads above regular whorls, usually 
Figure 6. Nitella mirabilis. A. Terminal whorls of branchlets of mature male plant (62-4-26-1), X 5. B. Branchlet node displaying two antheridia; lateral antheridium on reduced branchlet segment (63-4-26-1), X 10. C. Branchlets displaying 1, 2, and 3-furcate condition (62-4-24-1), X 2.5. 


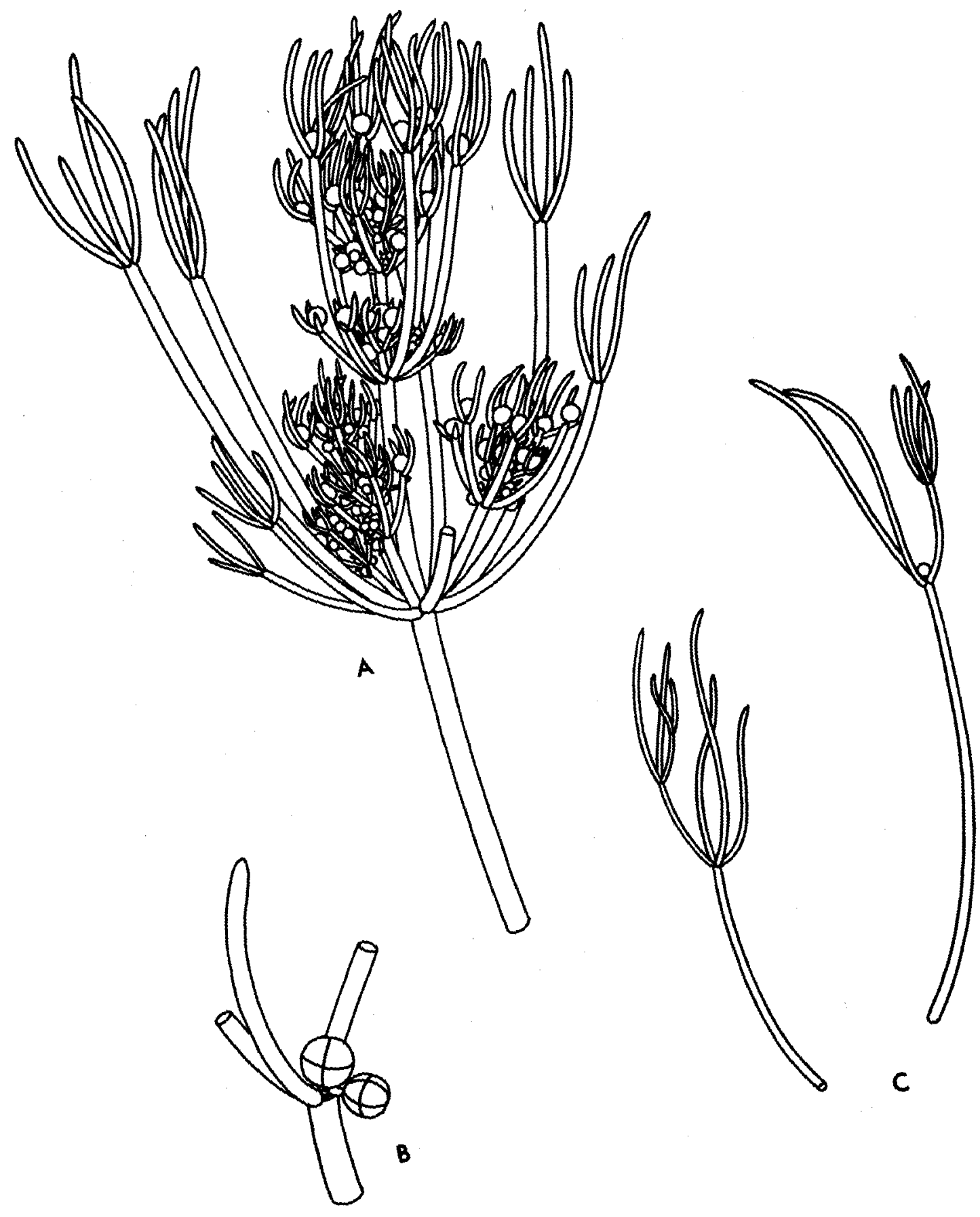


$-30-$

Figure 7. Nitella mirabilis $(62-1-26-3 B)$. Terminal whorls of branchlets of mature female and male plants, X 10 . 


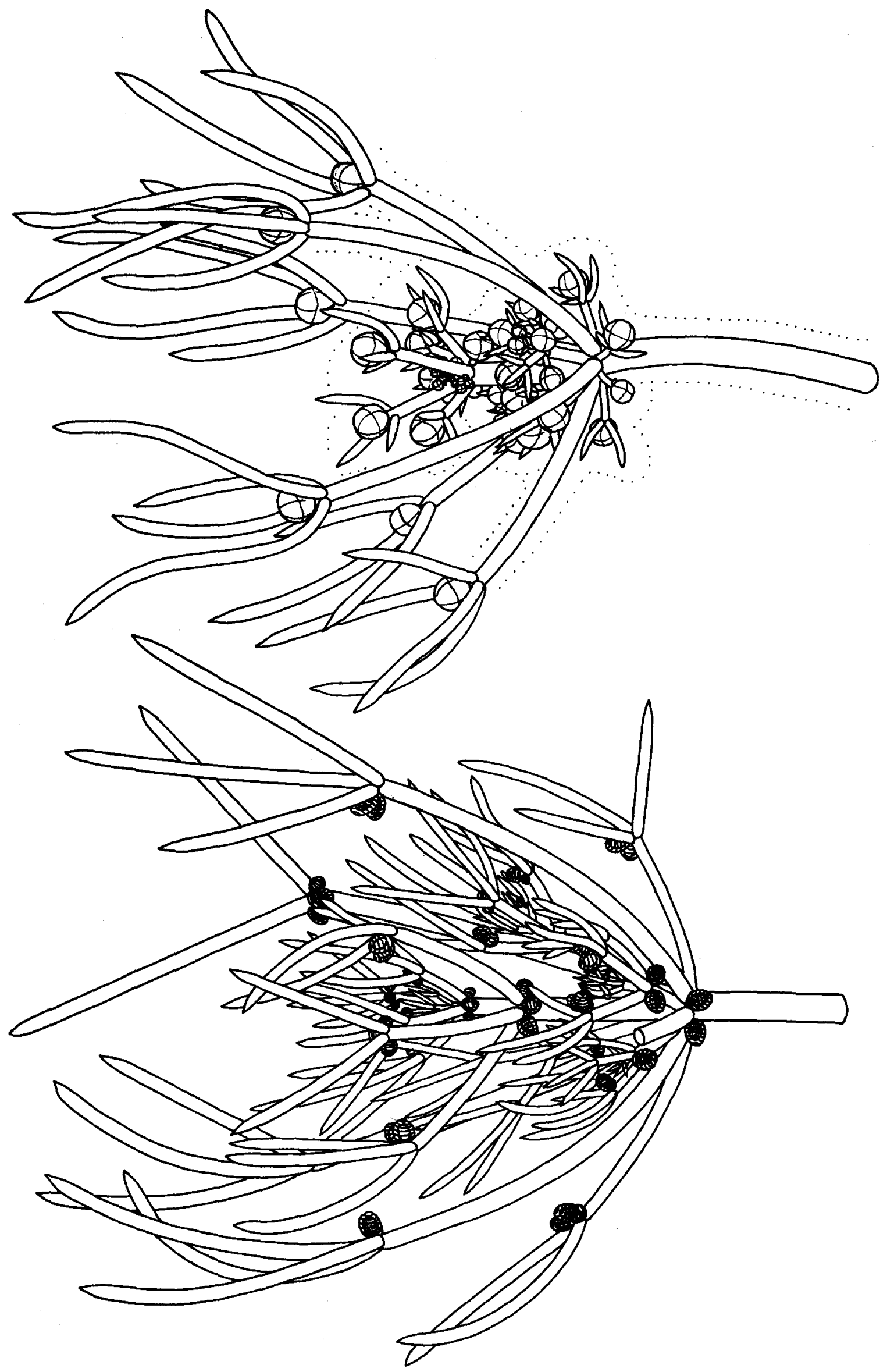


Figure 8. Range of variation in dactyl apices of Nitella mirabilis: A. $62-4-26-1$, B. $62-4-24-1$, C. IH $3-30-64$, D. 62-1-26-3b, B. 62-4-29-8, X 66. 

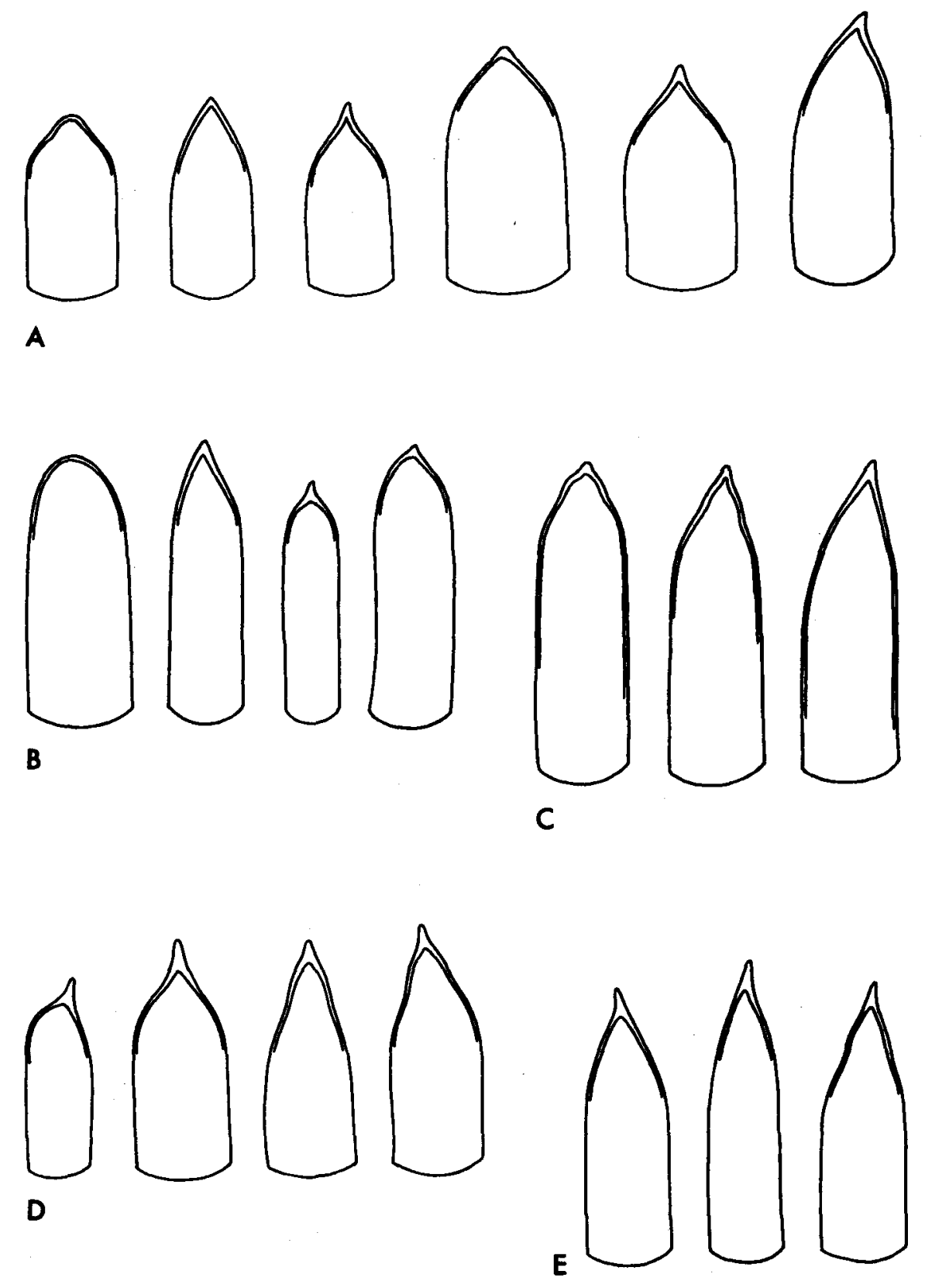
reduced and fert1le. Branches 2-5 elongate ones at lower nodes, 2-6 forming heads. Gametangia-male and female on separate plants, most abundant in heads. Oogonia 1-3 at a branchlet node, regularly occurring on short otalks in heads (reduced secondary branches and branchlets, and adrentitious branchlets), frequently sessile at base of whorl (at position of secondary branchlet), 405-480 $\mathrm{p}$ long (excluding coronula), 345-430 $\mu$ wide, slightly swollen at apices; coronula markedly deciduous, two measured $43 \mu$ high, 65-68 $\mu$ wide. Oospores merlium brown to dark brown, 255-315 $\mu$ long, 225-285 $\mu$ wide; striae of (5-) $6(-7)$ prominent ridges, sometimes flanged; D.E.A. 43-72 $\mu$; membrane relatively smooth or finely granulate. Antheridia solitary (sometimes 2 at a node), not sessile at base of whorl but appearing stalked in heads or when occurring together at branchlet nodes, 555-810 $\mu$ in diameter, 8-scutate.

SPECTMENS EXAMTNED: KANSAS: $(62-4-24-1$ and $63-4-26-1)$ Ione Star Lake, in and near Washington Creek Branch, Douglas Co., Kansas, D. Tindall, A. Hotchkiss, and W. Minckley, April 24, 1962; A. Hotchkiss and T. Sawa, April 26, 1963. (62-4-26-1) Shallow pool at edge of Murray's Lake, Miami Co., Kansas, D. Tinda11, A. Hotchkiss, and W. Minckley, April 26, 1962. (62-4-26-3B) Shallow pool, Marais des Cygnes Waterfowl Refuge, Area D. Iinn Co., Kansas, D. Tinda11, A. Hotchkiss, and W. Minckley, April 26, 1962. (61-3-27-IB) Garnett Quarry pond, 3 mi. N. Gamett, Anderson Co., Kansas, D. Tindall, W. Minckley, and J. Craddock, March 27, 1961. (62-4-27-4) Cedar Creek, U.S. Hwy I66 W Sodan, Chautauqua Co., Kansas, D. Tindall, A. Hotchkiss, and W. Minckley, April 27, 1962.

OKI.AHOMA: (62-4-28-2 tent. det.) Buffalo Spring, Platt National Park, Murray Co., Oklahoma, D. Tindal1, A. Hotchkiss, and W. Minckley, April 28, 1962. (62-4-29-8) Pool in spring fed stream, 2.6 m. S 
Antlers, U.S. Hwy 27, Pushma taha Co., Oklahoma, D. Tindall, A. Hotchliss, and W. Minckley, April 29, 1962. (62-4-29-2) Stream, 8 mi W Hugo, U.S. Ho, Choctaw Co., Oklahoma, D. Tindall, A. Hotchkiss, and W. Hinckiey, April 29, 1962.

TEXAS: (IH 3-30-64) In quiet pool in P1um Creek, Section 456, 2 mi. S. Lipscomb, Lipscomb Co., Taxas, Loren Hill, March 30, 1964.

TIPE LOCALITI: India (Groves, 1924).

DISTRIBUFION: Nitella mirabilis has heretofore been recorded only from Asia. The apecies was first distinguished and named (manuscript) by Nordstedt from specimens collected in China but was later described from specimens collected in India by G. 0. Allen (Groves, loc. cit.). Recently specimens resembling this species were collected in Japan (N. inokashiraensis Kasaki $=$ N. mirabilis var. inokashireansis vide Wood and Imahori, 1964). Although the species appears to be quite rare, some very closely related species show a much wider distribution. These include $\mathrm{N}$. capillaris which occurs in Europe, Africa, Asia, and possibly in North America; and H. syncarpa which occurs in Europe and Asia (Wood and Imahori, 1959).

The known distribution of Nitella mirabilis in North America is shown in Figure 9. Some very closely related forms have been reported from elsewhere on the continent but they can not be included in the present complex at this time. These include such forms as $\underline{\mathbb{N}}$. bastinii which is known only from a single locality in Illinois (Allen, 1894), and specimens identified as $\underline{N}$. capitata ( N. capillaris) from New York (Allen, loc. cit.). Wood and Muenscher (1956) stated that the latter specimens proved to be $\underline{\mathrm{N}}$ flexilis. However, Allen's description and illustrations clearly depict plants similar to those of the present study. 


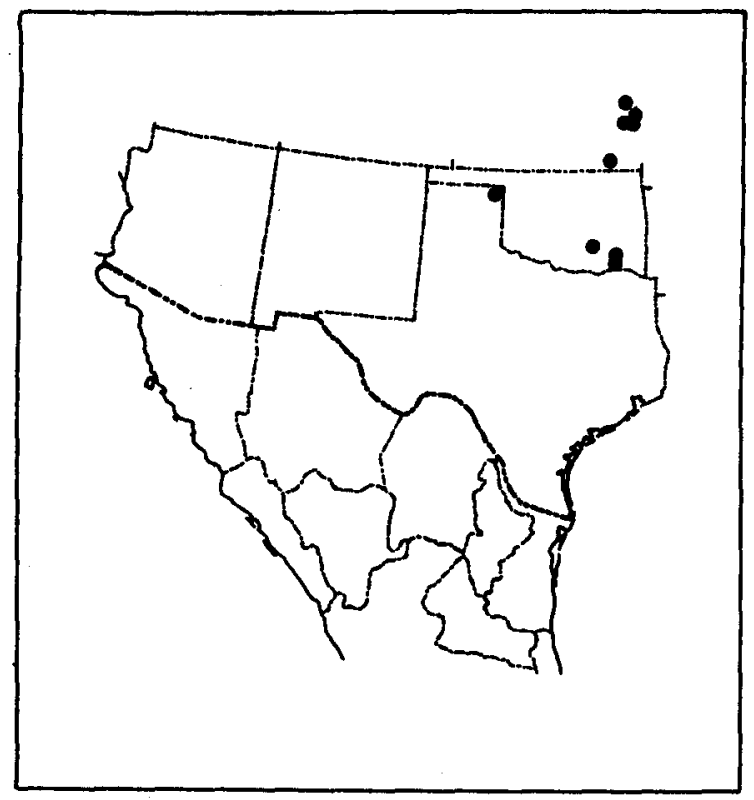

Fig. 9. Distribution of Nitella mirabilis in the study area. 
of particular interest in respect to distribution is the distinct overlap in the ranges of $\underline{\mathbb{N}}$ mirabilis and $\underline{\mathrm{N}}$. missouriensis. Some specimens of each species show various characters which indicate that hybridization has occurred. However, the species were easily distinguished in the single locality where they were observed together.

BCOLGY: Physicochemical features of the habitats.-Various features of the habitats supporting Nitella mirabilis are included in Table 3. The species was observed most frequently in small shallow pools of slow-flowing streams. The habitats were generally characterized by a rich fine-textured substrate, and cool, clear, heavily shaded waters which displayed a relatively high alkalinity, a neutral to moderately alkaline $\mathrm{pH}$, and an abundance of free carbon dioxide.

The rery similar characters of most of the habitats suggest that the species is capable of inhabiting only a narrow range of environmental conditions. Such conditions are most common in the study area in early and midspring. This is in close agreement with the strictly vernal occurrence of the species. On the basis of present collections, the species is judged to have a growing season in the study area beginning in late March and ending in late April or early May. The rapid disappearance of the species in late spring may be a result of its inability to compete with other aquatic plants which begin growth at that time. However, increases in light and temperature and their indirect effects on water chemistry appear to be most influential in speeding up the life cycle of the species.

Plant communities.-All but a single locality for $\underline{\mathrm{N}}$. mirabilis in Kansas also supported luxuriant stands oi Tolypella sp. The small pool from which collection $62-4-26-3 B$ was made did not contain Tolrpella

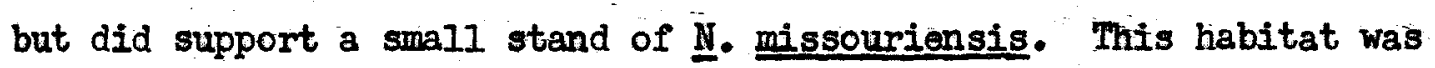


Table 3. Physicochemical features of habitats supporting Nitella mirabilis.

\begin{tabular}{|c|c|c|c|c|c|c|c|c|c|c|c|}
\hline Speoimens & Locali ty & Habitat & Substrate & Depth & $\begin{array}{l}\text { Tur- } \\
\text { bidity }\end{array}$ & Light & $\begin{array}{l}\text { Tempe } \\
\text { air }\end{array}$ & $\begin{array}{l}\text { rature } \\
\text { water }\end{array}$ & $\mathrm{pH}$ & Alk. & $\mathrm{CO}_{2}$ \\
\hline $62-4-24-1$ & Kansas & $\begin{array}{l}\text { slow s tream } \\
\text { beaver pond }\end{array}$ & $\begin{array}{l}\text { mud-silt } \\
\text { silt-m } \\
\text { organie }\end{array}$ & $\begin{array}{l}0.15-0.3 \\
0.30-0.5\end{array}$ & $\begin{array}{l}0 \\
0\end{array}$ & $\begin{array}{l}\text { shaded } \\
\text { shaded }\end{array}$ & $\begin{array}{l}30.0 \\
30.0\end{array}$ & $\begin{array}{l}22.0 \\
20.0\end{array}$ & $\begin{array}{l}7.5 \\
7.9\end{array}$ & $\begin{array}{l}391 \\
222\end{array}$ & $\begin{array}{r}23.0 \\
5.0\end{array}$ \\
\hline $62-4-26-1$ & Karsas & small pool & $\begin{array}{l}\text { organic- } \\
\text { silt }\end{array}$ & $0.10-0.15$ & 0 & shaded & 25.0 & 17.0 & 7.1 & 263 & 40.0 \\
\hline $62-4-26-3 B$ & Kansas & small pool & $\begin{array}{l}\text { organic- } \\
\text { silt }\end{array}$ & $0.15-0.20$ & + & open & 31.0 & 28.0 & 7.4 & 167 & 12.5 \\
\hline $62-4-27-3$ & Kansas & slow s trean & $\begin{array}{l}\text { silt- } \\
\text { gravel }\end{array}$ & $0.10-0.30$ & 0 & shaded & $\therefore$ & 19.0 & 8.0 & 209 & 4.0 \\
\hline $62-4-28-2$ & Oklahoma & $\begin{array}{l}\text { swift spring } \\
\text { stream }\end{array}$ & sand & $0.05-0.30$ & 0 & shaded & 22.0 & 17.0 & 7.2 & 326 & 40.0 \\
\hline $62-4-29-2$ & Oklahoma & s tream pool & $\operatorname{mar} 1-811 t$ & $0.20-0.30$ & 0 & open & 26.0 & 19.0 & 7.9 & 242 & 6.0 \\
\hline $62-4-29-8$ & Oklahcma & stream pool & silt & $0.20-0.70$ & 4 & shaded & 27.0 & 22.0 & 7.1 & 50 & 6.8 \\
\hline
\end{tabular}


characterized by rather warm waters and was open to maximum insolation. Nitella mirabilis was sexually mature, whereas $\underline{N}$. missouriensis was quite joung. A somewhat aknormal form of $\underline{\mathrm{N}}$. mirabilis (tent. det.) occurred as isolated tufts in the swiftly flowing waters of Buffalo Spring (Murray Co., Oklahoma, 62-4-28-2). Similar tufts of N. gracilis were also present in the current and Chara vulgaris formed small beds in less agitated waters. Batrachospermum sp. was abundant in areas of strong current, and Nasturtium officinale was abundant at the source and along the banks of the stream. The stream locality in Choctaw County, Oklahoma, displayed a mixed association of Tolvpella sp., Chara schaffnerii, and Nitella mirabilis. The Tolvpella and Nitella formed rather extensive beds, whereas the Chara was less abundant. The spring pool in Pushmataha County, Oklahoma, was quite different from the other habitats found to support Nitella mirabilis (Table 3). The surrounding area displayed a more or less boggy character. The species occurred in the deeper parts of the pool, whereas species of Potamogeton, Sagittaria, Callitriche, Porella, and various mosses inhabited the shallow waters and moist banks. The latter habitat was the only one observed that supported a significant phanerogamic flora.

MORPHOLOGY, CYTOLOGY, AND TAXONOMY: The range of variation in Nitella mirabilis from the study area is included in the description. For the most part, the species was very consistent with regard to basic regetative morphology, including the numbers and lengths of branchlets, dactyls, and secondary branches. The most striking variation among the specimens was the shape of dactyl apices, ranging from blunt to nearly acuminate (Fig. 8). Specimens with the more acuminate dactyls usually displayed numerous basal oogonia. However, the latter condition was observed to some extent on most of the specimens examined. 
A comparison of gametangia and oospores of the mature specimens of N. mirabizis is shown in Table 4. The oogonia and oospores were remarkably consistent throughout the area studies; but the antheridia were somewhat variable. Such rariation is typical for this group of Nitella (see discussion under N. missouriensis).

A chromosome number of 6 was observed in spectmens from collections $62-4-24-1,62-4-26-1,62-4=27-4,62-4-28-2$, and $62-4-29-2$. As mentioned above, chromosome numbers of 6 have been reported for N. mirabilis from India and N. inokashiraensis ( $N$. mirabilis vide Wood and Imahori, 1964) from Japan, and for the closely related ‥ opaca, ‥ syncarpa, and $\mathbb{N}$. 18souriensis.

The name Nitella mirabilis is presently used since its description best fits the morphology of the plants being studied. It is possible that this form may represent a product of hybridization that has occurred independentIy on various continents. Notwithstanding the apparent intergrades between N. mirabilis and N. missouriensis, both appear to be wellestablished species in Morth America. 
Table 4. A comparison of gametangia and oospores of Nitella mirabilis from Kansas and Oklahoma.

\begin{tabular}{|c|c|c|c|c|c|c|c|c|}
\hline SPEC IMENS & & $\begin{array}{l}\text { OOGONIA } \\
\text { length }\end{array}$ & width & $\begin{array}{l}\text { OOSPORES } \\
\text { leng th }\end{array}$ & width & no. ridges & D.E.A. & $\begin{array}{l}\text { ANTHERIDIA } \\
\text { diame tor }\end{array}$ \\
\hline $62-4-24-1$ & $\begin{array}{l}\mathrm{N} \\
\mathrm{R} \\
\mathbf{H}\end{array}$ & - & & & & - & - & $\begin{array}{l}20 \\
705-810 \\
743+6.9\end{array}$ \\
\hline $62-4-26-3 B$ & $\begin{array}{l}\mathrm{N} \\
\mathrm{R} \\
\mathbf{u}\end{array}$ & $\begin{array}{l}15 \\
405-480 \\
434 \pm 5.8\end{array}$ & $\begin{array}{l}345-375 \\
359 \pm 3.3\end{array}$ & $\begin{array}{l}20 \\
255-285 \\
273 \pm 2.8\end{array}$ & $\begin{array}{l}225-260 \\
249 \pm 2 \cdot 6\end{array}$ & $5-6$ & $\begin{array}{l}43-54 \\
48 \pm 0.6\end{array}$ & $\longrightarrow$ \\
\hline $\begin{array}{l}63-4-26-1 \\
\text { (culture) }\end{array}$ & $\begin{array}{l}N \\
R \\
\mathbf{H}\end{array}$ & $\begin{array}{l}4 \\
450-480\end{array}$ & $405-430$ & $\begin{array}{l}15 \\
285-315 \\
297 \$ 2.7\end{array}$ & $\begin{array}{l}240-270 \\
258 \pm 2.9\end{array}$ & $5-6$ & $\begin{array}{l}58-72 \\
64 \pm 1.3\end{array}$ & 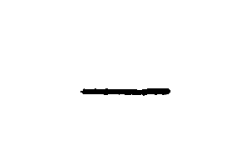 \\
\hline $62-4-28-2$ & $\begin{array}{l}\mathbf{N} \\
\mathbf{R} \\
\mathbf{H}\end{array}$ & $\longrightarrow$ & $\longrightarrow$ & $\begin{array}{l}15 \\
270-300 \\
291 \pm 2.6\end{array}$ & $\begin{array}{l}240-270 \\
252 \pm 2.3\end{array}$ & $6-7$ & $\begin{array}{l}47-54 \\
50 \pm 0.8\end{array}$ & $\begin{array}{l}15 \\
555-635 \\
605 \pm 6.7\end{array}$ \\
\hline $62-4-29-2$ & $\begin{array}{l}\mathbf{H} \\
\mathrm{R} \\
\mathbf{u}\end{array}$ & $\begin{array}{l}2 \\
435-450\end{array}$ & $390-405$ & $\begin{array}{l}15 \\
265-315 \\
292+3.6\end{array}$ & $\begin{array}{l}255-280 \\
267 \pm 2 \cdot 2\end{array}$ & 6 & $\begin{array}{l}43-58 \\
50+1.3\end{array}$ & $\begin{array}{l}15 \\
570-645 \\
624 \pm 5.8\end{array}$ \\
\hline $62-4-29-8$ & $\begin{array}{l}\mathbf{N} \\
\mathbf{R} \\
\mathbf{H}\end{array}$ & $\begin{array}{l}2 \\
435-457\end{array}$ & $390-405$ & $\begin{array}{l}20 \\
270-315 \\
291+2.6\end{array}$ & $\begin{array}{l}240-285 \\
267 \pm 2.7\end{array}$ & $6-7$ & $\begin{array}{l}40-54 \\
48 \pm 0.9\end{array}$ & $\begin{array}{l}20 \\
660-780 \\
726 \pm 7.5\end{array}$ \\
\hline
\end{tabular}


NITZLLIA HOTCHKISSII sp. nov.

Figures 10-11

DESCRIPTION OF SPBCIMENS (including the HOLOTYPE AND 5 ISOTYPES): Plantae dioeciae, coloris viridis, $23-48 \mathrm{~cm}$ altae, diffusae et capita formantes. Primariae axes $645-825 \mu$ in diam., internodia ramulis breviora vel aequalia. Verticillorum ramuli 8-9, capita formantes alii diffusi alii contracti, heteroclema; ramuli primarii 6, consistentes in capitibus, alii breves alii usque ad $8.8 \mathrm{~cm}$ longi, omnes 2-furcati; radii secundarii (2-) 3-4; radii tertiarii (dactyli $2(-4)$ omes acuminati. Ramuli secundarii breve, I (-2)-furcati. Oogonia 2-3 aggregata, 300-330 $\mu$ lata, 335-375 $\mu$ longa (dum coronulam excipias); coronula decidua, 48-54 $\mu$ alta, 61-66 $\mu$ lata. Oosporae rubro-brunneae, 225-255 $\mu$ longae, 210-240 $\mu$ latae; striae 5-6; membrana spongia. Antheridia 585-720 $\mu$ in diam.

Plants dioecious (male and female plants similar), $23-48 \mathrm{~cm}$ high, spreading, with distinct terminal and axillary heads composed of reduced secondary branches and primary and secondary branchlets, medium green, not incrusted with lime. Main axes 645-820 $\mu$ in diameter; internodes to $7 \mathrm{~cm}$ long, usually shorter than branchlets. Branchlets not differentiated into fertile and sterile types but occurring as elongate and contracted ones, 8-9 in a whorl, of 2 types: PRIMARY BRANCHLETS 6 in a whorl, from a few (in heads) to $8.8 \mathrm{~cm}$ (in expanded whorls) long, 2-furcate; primary rays ca. $1 / 3$ branchlet length; secondary rays (2-) 3-4 at a node, ca. 1/3 branchlet length, usually forked again but frequently simple or 2-celled ( 1 tertiary ray); tertiary rays (dactyls) (I-) $2(-4)$ at a node, ca. I/3 branchlet length, 1-celled (rarely 2-celled or forked again into 2 quaternary rays), very gradually acuminate. SECONDARY BRANCHIETS $2-3$ in a whorl, occurring opposite secondary branches and slightly below and alternating with primary branchlets, 
Figure 10. Nitella hotchkissii IsOTYPE (FB 4-4-61). A. Terminal whorls of branchlets of mature male plant, X 4; some branchlets not drawn. B. Range of variation in dactyl apices of male and female plants, X 66 . 


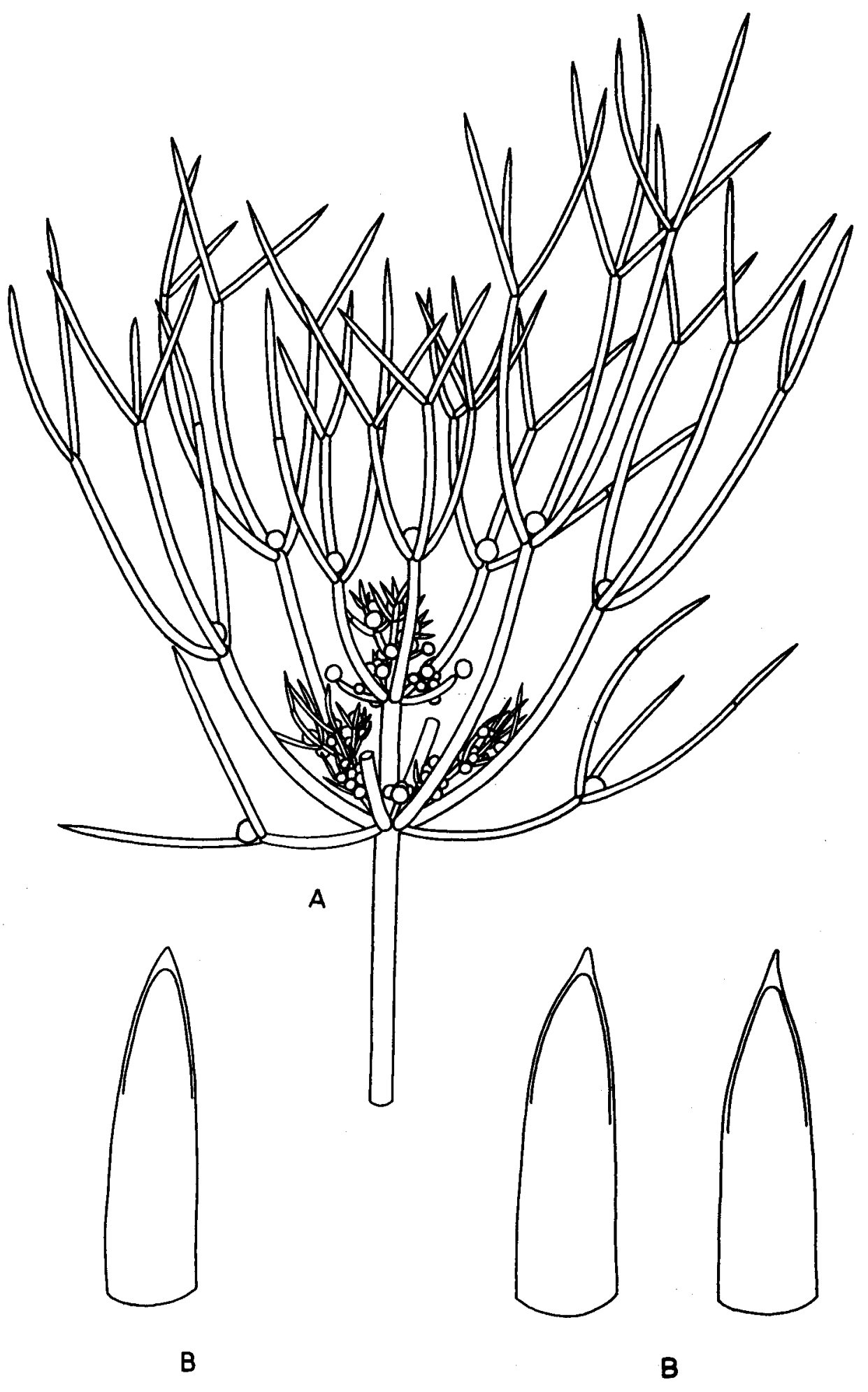


Figure 11. Nitella hotchkissii HOLOTYPE (FB 4-4-61). Habit sketch of mature female plant, $X 1 / 2$. Some branchlets and branches not drawn. 


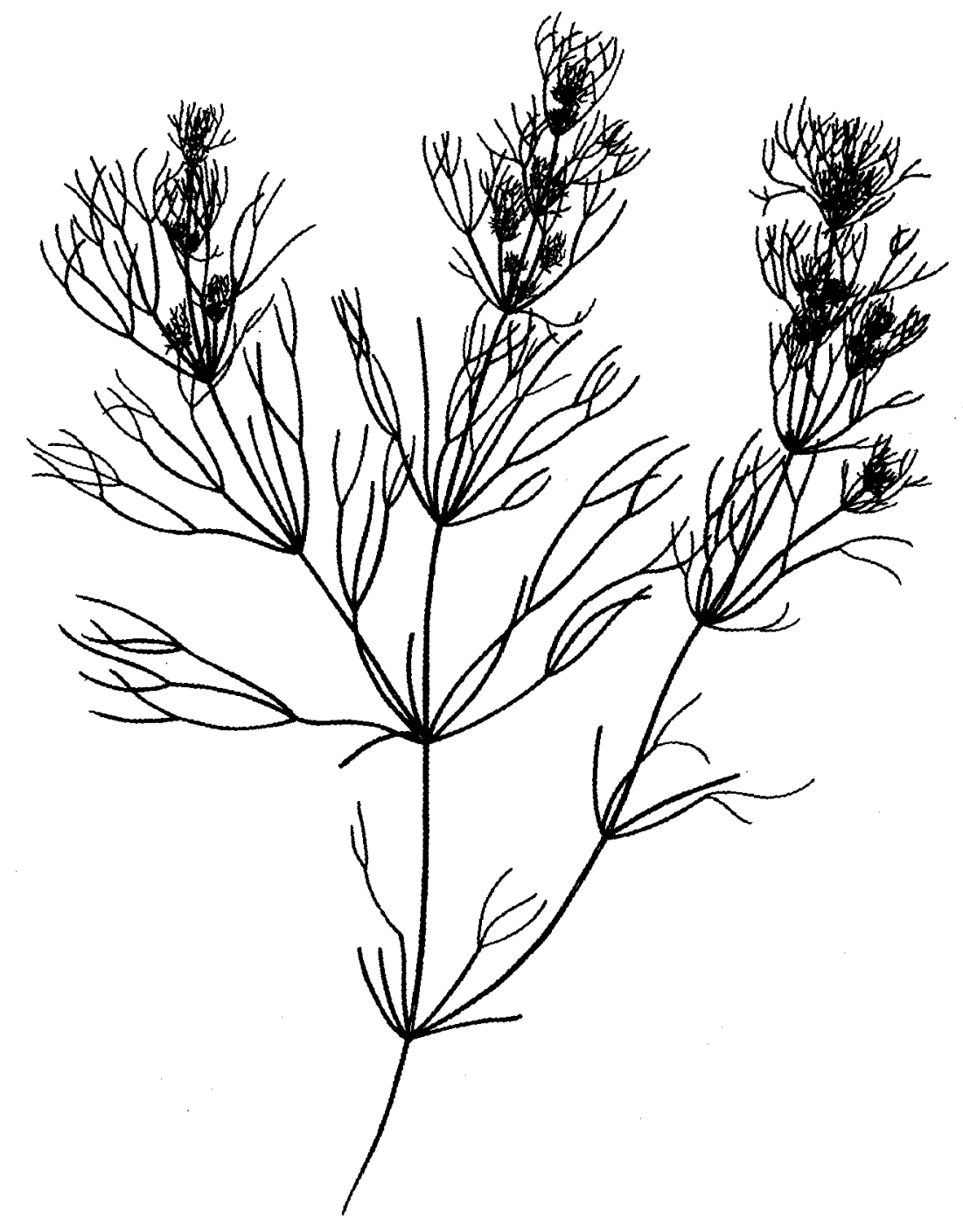


shorter and less forked than associated prinary branchlets. Branches usually 2 but frequently $3-4$ in heads. Gametangia-male and female on separate plants, most abundant in heads. Oogonia (N=15) sessile but sometimes occurring on reduced branchlets of heads which appear to be long stalks, usually 3 at lst node and 2 at 2nd node, (335-) 359:2.5 $(-375) \mu$ long (excluding coronula), (300-) 31 $1 \pm 2.1(-320) \mu$ wide; coronula $(N=2)$ very early deciduous, 48-54 $\mu$ high, 61-66 $\mu$ wide. Oospores $(N=20)$ dark red-brown, (225-) $243 \pm 1.8(-255) \mu$ long, (210-) $228 \pm 1.9(-240) \mu$ wide; striae of 5-6 very inconspicuous ridges; D.E.A. (43-) $50=1.0(-58) \mu$; membrane distinctly spongiform. Antheridia $(N=30)$ solitary but sonetimes appearing to be aggregate on very reduced secondary branches of heads, usually limited to lst branchlet node, (585-) $657 \pm 6.7(-720) \mu$ in diameter, 8-scutate.

TIPB LOCALITY: (FB and RG 61-4-4) Roadside ditch, along U.S. Hwy 79, 8.8 mi. SN Palestine, Anderson Co., Texas, Fred Bryan and Richard Goodyear, April 4, 1961. The HOLOTYPE is a mature female plant (Fig. 10) and the ISOTYPES include mature male and female plants.

This species is named in honor of Dr. Arland T. Hotchkiss who has contributed to our knowledge of the Characeae through several publications and who has been of invaluable assistance throughout this study.

CYTOLOGY: No cytological samples were prepared in the field; however a tentative count of 6 chromosomes was made on specimens preserved in formalin.

REIATIONSHIPS: A comparison of the descriptions and illustrations of Nitella hotchkissii, N. mirabilis, and N. missouriensis reveals the basic similarity of these species. Except for the twice-furcate branchlets, the general vegetative morphology of the new species is nearly identical to that of N. missouriensis. This is especially 
evident in the numbers and types of branchlets and branches, head formation, and the shape of dactyl apices. In respect to size of gametangia and oospores, N. hotchkissii shows a closer relationship to $\underline{N}$ mirabilis. The occasional twice-furcate branchlets of $\mathbb{N}$. mirabilis also indicate a close relationship. Although $\underline{\mathbb{N}}$. hotchkissii is distinctly related to these species, it clearly represents an independent taxon separable at the species level.

In addition to the above, Nitella hotchkissii displays certain similarities to other previously described species, namely $\underline{\mathbb{N}}$. stuartij Braun, N. macounii Allen, and N. allenij Imahori. These species closely parallel $\mathbb{N}$. hotchkissii in general morphology of primary branchlets and in size of oogonia and oospores. However, all three previously described species are monoecious and are characterized by very small antheridia. The total range of antheridial diameters recorded for the three species is 120-220 u (Wood and Imahori, 1964) as compared with 585-720 u in ‥ hotchkissii. The very small antheridia, along with several other features, clearly align N. stuartii, ‥ macounii, and $\mathrm{N}$. allenij with the $\mathbb{N}$. acuminata complex, whereas the large antheridia and basic vegetative characteristics of N. hotchkissii show it to be distinctly related to $\mathrm{N}$. missouriensis-mirabilis-like plants. 
NITEIIA ACUMINATA Bram ex WaIIman

Figures $12-14$

Nitella acuminata var. belangeri Braun (1849:292).

N. acuminata WaIlman (1853:35).

11. Iindheimeri Braun (1859 vide Wood, 1962).

N. subglomerata Braun (1859:336); AIlen (1892).

N. acuminata var. subglomerata Braun and Nordstedt (1882).

N. acuminata f. subglomerata Wood (Wood and Inahori, 1964).

N. gollmeriana Braum (1859:355).

N. acuminata $\mathrm{ssp}$ golimeriana Braun (Braun and Nordstedt, 1882).

N. acuminata var. gollmeriana Zaneveld ex Wood (Wood and Imahori, 1964).

I. mexicana Allen (1894:165).

N. subspicata Allen $(1896: 6)$.

N. Stellaris Allen (1896:534).

N. acuminata f. stellaris Wood (Wood and Imahori, 1964). LITERATURE FOR THE STUDY AREA: Braun (1894, 1859), Braun and Nordstedt (1882), Allen (1892, 1894, 1896), Zaneveld (1940), Wood (1948), Allen (1954), and Wood and Imahori (1964).

DESCRIPTION OF SPECIMENS (including three or more plants from each collection): Plants monoecious, $10-26 \mathrm{~cm}$ high, usually forming terminal and axillary heads composed of 4-6 reduced whorls and 2-3 reduced secondary branches in each whorl, nedium green to dark green, lightly to moderately incrusted with lime in distinct bands. Main axes 440-885 $\mu$ in diameter, internodes longer than branchlets on lower parts of plants but juch shorter in heads. Branchlets not differentiated into fertile and sterile types but occurring as elongate and contracted ones, the latter forming distinct terminal and axillary heads which usually are more fertile than elongate ones: both types similar, (6-) 8-9 (10) 
Figure 12. Nitella acuminata. A. Terminal whorls of branchlets of mature plant (61-9-8-5), X 5. B. Range of variation in dactyl apices (61-9-8-5), X 66. C. Terminal whorls of branchlets of mature plant (61-9-8-3), X 10 . D. Terminal whorls of branchlets of mature plant (61-9-8-3), X 5. E. Dactyl apex (61-9-8-3), X 75 . 


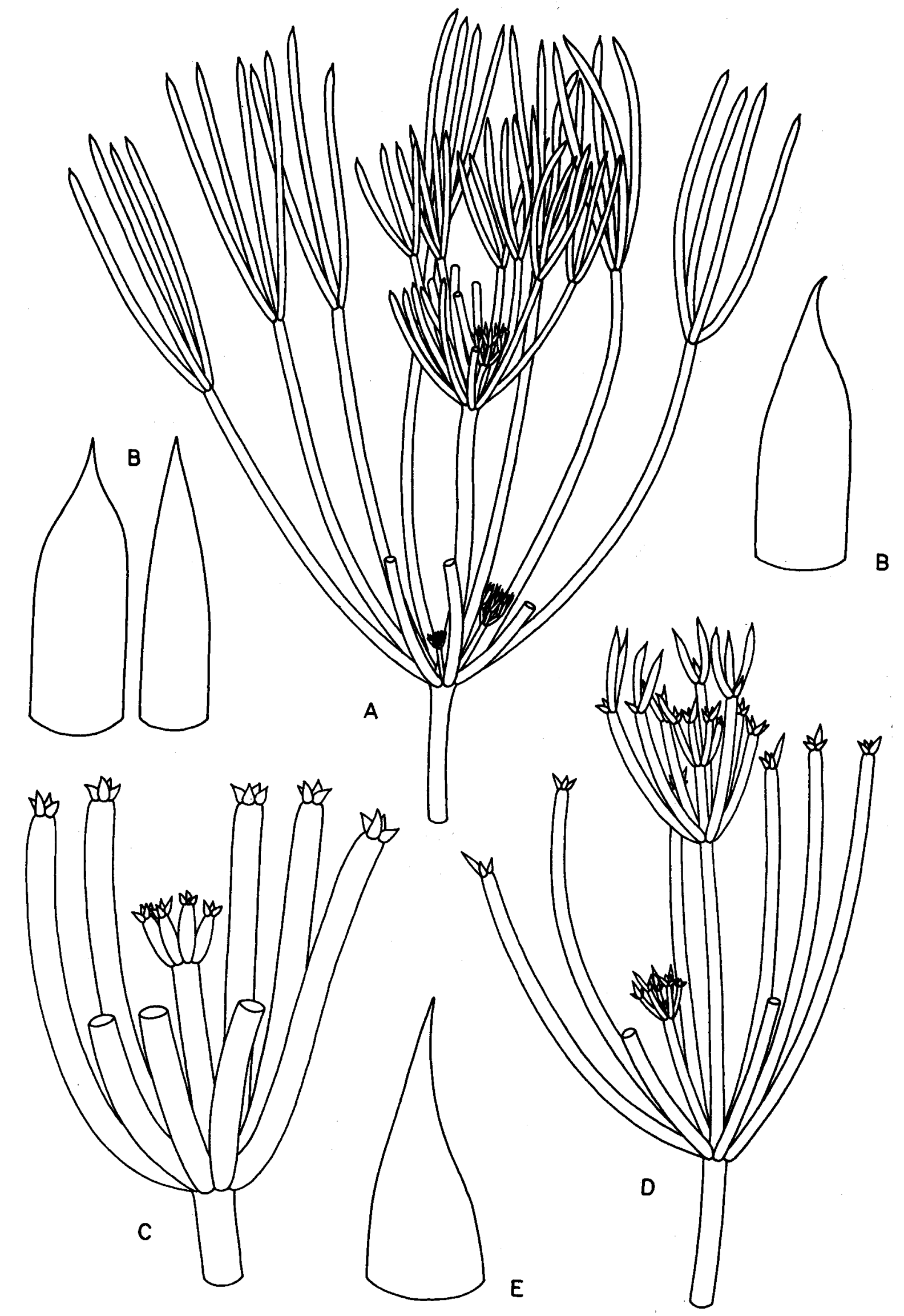


Figure 13. Nitella acuminata. A. Terminal whorls of branchlets of mature plant (61-9-8-5), X 10. B. Apex of mature dactyl (6I-9-8-5), X 66. C. and D. Terminal whorls of branchlets of mature plant (61-9-9-1), X 10. E. Apices of young dactyls (61-9-9-1), X 50. F. Terminal whorls of branchlets of mature plant (61-9-15-6), X 5. G. and H. Characteristic branchlets of fertile heads (61-9-15-6); G. X 33, H. X 42. I. Dactyl apices $(61-9-15-6), \times 50$. 


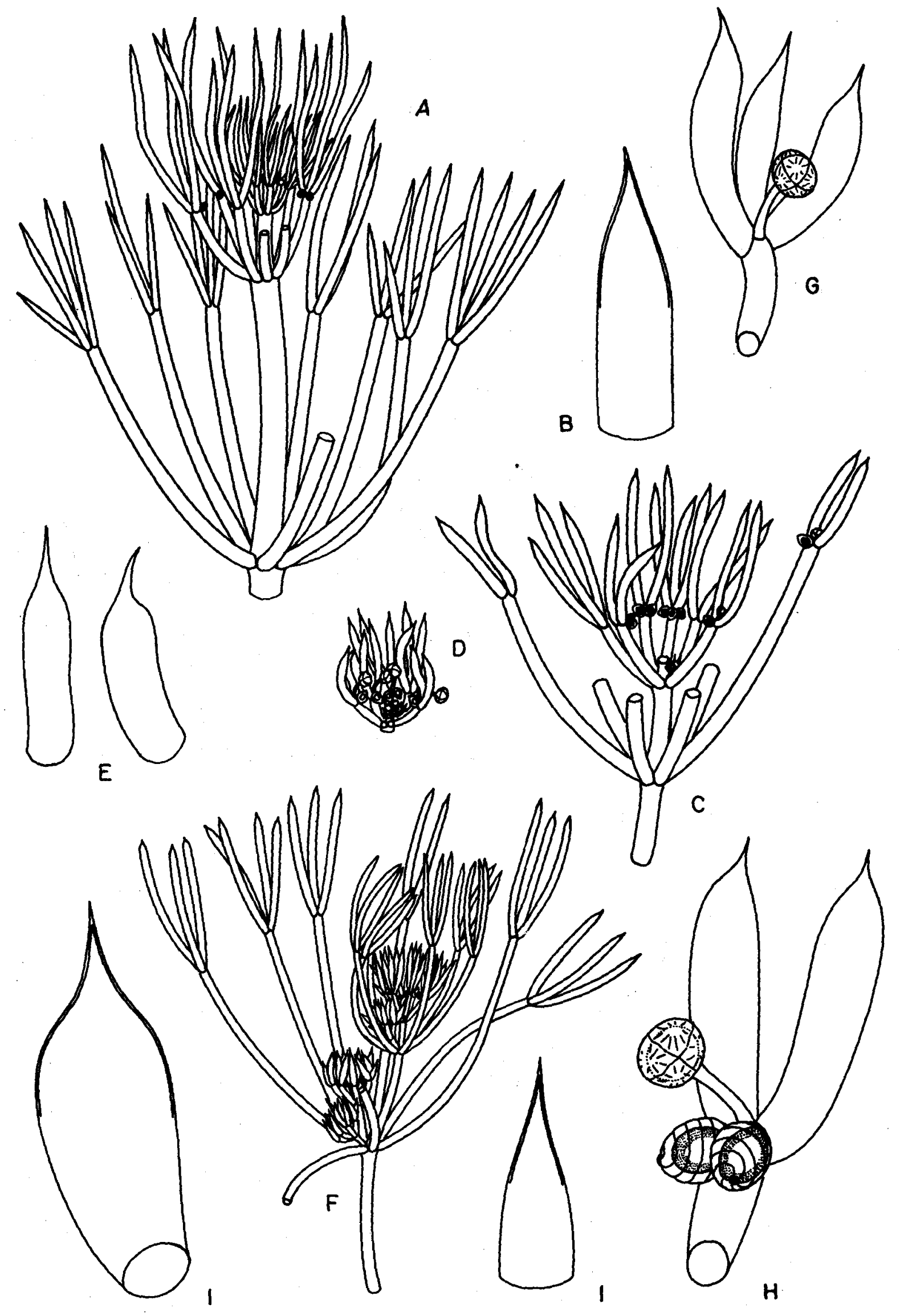


Figure 14. Nitella acuminata $(63-1-25-1)$. A.-F. Details of fertile head; D.-F. also characterizes terminal whorls following C, X 10. G. Apex of mature dactyl, X 66. H. Apices of young dactyls, X 66. I. Characteristic branchlets of some fertile heads, X 25 . 

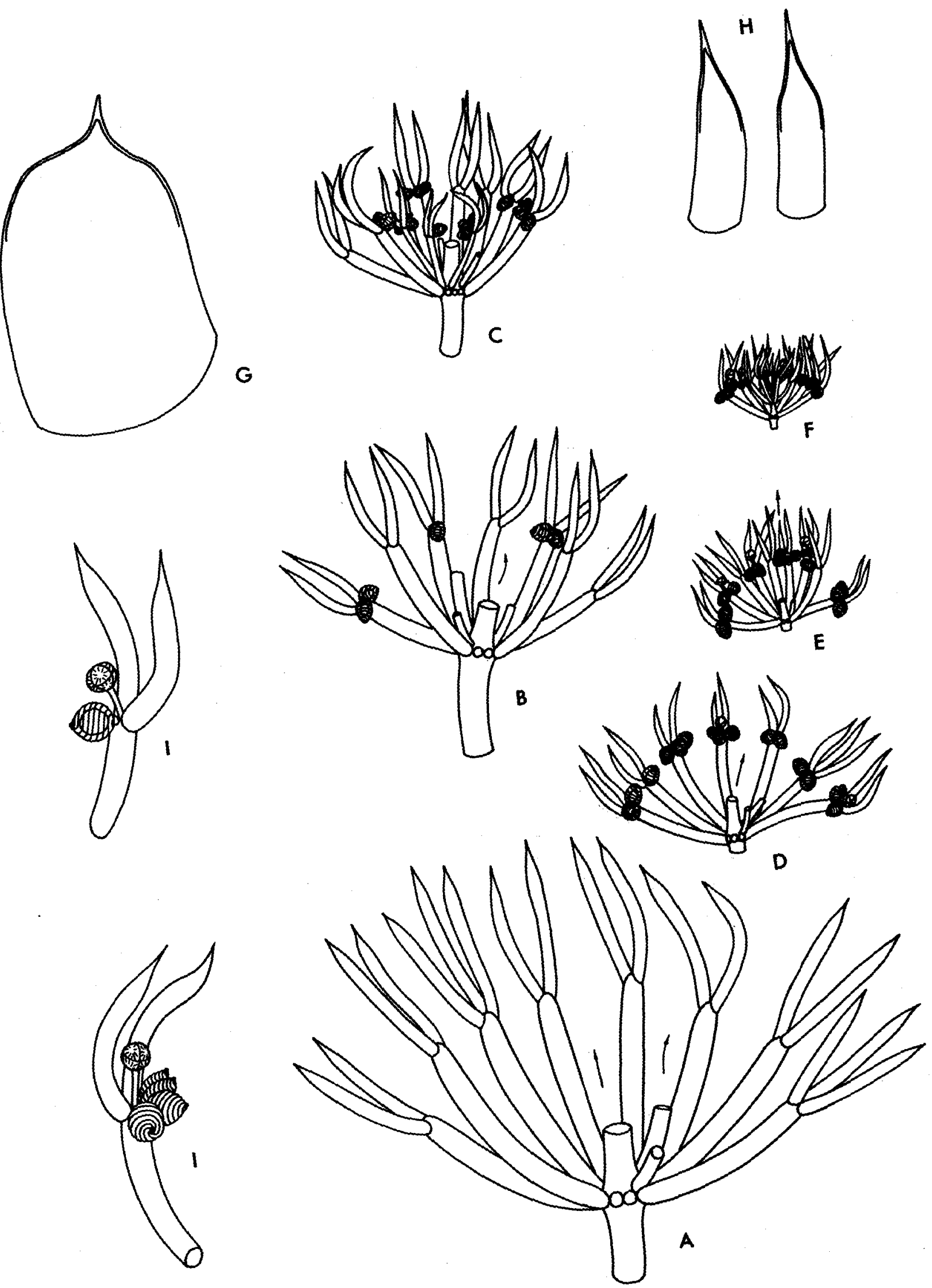
in a whorl, l-furcate, from a few $\mathrm{mm}$ (in heads) to $5.5 \mathrm{~cm}$ (in expanded whorls) long. Ultimate rays 1-celled, (2-) 3-4 (-6) at a node, forming a very minute stellate crown at tip of primary rays and/or elongate to $1 / 2$ branchlet length, slightly swollen when very young, distinctly acuminate. Adventitious branchlets very rare, 1-4 (simple or 1-furcate), forked ones occurring in heais above regular branchlets, simple ones occurring at position of regular branchlet (appearing as dactyls of a reduced branchlet). Branches 2-3 at a node, elongate or reduced but otherwise identical to main axes. Gametangia conjoined at branchlet nodes, most abundant in heads. Oogonia sessile, (1-) 2-3 (-4) at a node, 320-460 $\mu$ long, $265-360 \mu$ wide; coronula persistent, $18-36 \mu$ high, 36-66 $\mu$ wide. Oospores dark brown, 208-280 $\mu$ long, 190-260 $\mu$ wide; striae of (6-) 7 prominent ridges; D.E.A. 33-61 $\mu$; membrane finely granulate. Antheridia solitary, somewhat flattened horizontally, 190-325 $\mu$ wide, 160-300 $\mu$ long, usually occurring on an antheridial stalk 50-1,80 $\mu$ long, 43-80 $\mu$ in diameter, 8-scutate.

SPECIMENS EXAMINED: OKLLHOMA: (HCE 64-10) Pond, ca. 4 mi. E boyscout carnp, S Locust Grove, State Hwy 82, Mayes Co., Oklahoma, Homer C. Enery, Oct. 1964 .

TEXAS: (61-9-15-6) Guadalupe River (limestone), along State Hwy 39, Kerr Co., Texas, D. Tindall, A. Hotchkiss, and R. Goodyear, Sept. $15,1961$.

TAMAULIPAS: (61-9-10-2) Arroyo Sarcas, $1.5 \mathrm{mi}$. W Encino (off Mex. Hwy 85) on road to Rio Sabinas, Tamaulipas, Mexico, D. Tindall, A. Hotchkiss, and R. Goodyear, Sept. 10, 1961.

SAN LUIS POTOSI: (61-9-9-1) Srall limestone stream flowing $\mathrm{W}$, $31 \mathrm{mj}$. S Cd. Mante, Nex. Hwy 85, San Luis Potosi, Mexico, D. Tindall, A. Hotchkiss, and R. Goodyear, Sept. 9, 1961. (61-9-8-5) and (63-1-25-1) Small sluggish stream, ca. $17 \mathrm{mi}$. N Cd. Valles, Mex. Hwy 85, San Luis 
Potosi, Mexico, D. Tindall, A. Hotchkiss, and R. Goodyear, Sept. 8, 1961;

D. Tindall and A. Hotchkiss, Jan. 25, 1963. (61-9-8-3). First arroyo (limestone) N Cd. Valles, Mex. Hwy 85, near Paima Hotel, San Luis Potosi, Mexico, D. TindaIl, A. Hotchkiss, and R. Goodyear, Sept. 8, 1961.

TYPE LOCALITY: Coast of Coromandel, India (Braun, 1849); Ile de 1a Réunion, Indian Ocean (Wallman, 1853).

DISTRIBUTION: The various forms comprising the Nitella acuminata complex have been reported from Africa, Asia, North America, and South America (Zaneveld, 1940; Hom af Rantzien, 1950; Wood and Imahori, 1959). The species displays a wide distribution in North and South America and the West Indies but appears to be most concentrated in tropical and subtropical regions.

Regions of North America, excluding the study area, known to support the species include New Hampshire (Braun and Nordstedt, 1882), Massachusetts (Braun and Norstedt, loc. cit.; Nordstedt, 1889; Allen, 1892), New York (Allen, 1892; Wood and Muenscher, 1956), New Jersey (Allen, 1892), Pennsylvania (Braun and Nordstedt, 1882; Allen, 1892), Ohio (Braun and Nordstedt, 1882), Illinois (Braun and Nordstedt, loc. cit.; Allen, 1892), Missouri (Allen, 1892), Kentucky (Hotchkiss, 1958), North Carolina (Wood, 1954), Alabama (Allen, 1892), Louisana (Allen, loc. cit.), Nebraska (Daily, 1944), Wyoming (Daily and Porter, 1961), and Oregon (Allen, 1892).

Various forms of Nitella acuminata have been recorded from Panama, Venezuela, British Guiana, Brazil, Puerto R1co, Martinique, and Trinidad (reviewed by Horn af Rantzien, 1950).

Representatives of the species have been reported from several localities in the study area, but precise collection data are available for only a few specimens. Braun (1859) described Nitella lindheimeri from Friedrichsburg (Fredrichsburg, Gillespie Co.) Texas. Braun and 
Nordstedt (1882) reported the same form as ‥ acuminata var. lindheimeri, and ‥ acuminata var. subglomerata from Fredrichsburg, Texas. Allen (1892) reported $\mathrm{N}$. subglomerata from seven Localities in Mexico but did not include collection data. Allen (1894) described N. mexicana from specimens collected in San Iuis Potosi but regarded the species as a close ally of N. flexilis. Wood (1962) concluded that the species was merely a form of N. flexilis; however, several data indicate that $\underline{N}$. mexicana is a member of the N. acuminata complex. Allen (1896) described N. stellaris from a single collection in northeastern Oklahoma (pond near Verdigris River, Creek Nation, Indian Territory, J. W. Blankinship, Aug. 21, 1895).

The known distribution of $\mathbb{N}$. acuminata in the study area is shown in Figure 15; however, several localities referred to as "Mexico" by Allen (1892) are not included. It is quite clear that the combined range of forms described as $\mathrm{N}$. stellaris, N. lindheimeri, and N. mexicana is nearly identical to that of specimens collected during this study.

BCOLOGY: Physicochemical features of the habitats.--Nitella acuminata appeared to grow best in shallow, quiet, well-lighted, and warm waters of limestone areas (Table 5). The substrates supporting the species consisted mostly of clay or silt. The waters usually displayed a moderately alkaline $\mathrm{pH}$, a rather high alkalinity, and a low chloride content (Table 5).

The single heavily shaded habitat contained only sterile plants with very reduced dactyls $(61-9-8-3)$. These plants produced numerous gametangia and elongate dactyls when transplanted in large glass tanks and exposed to full sunlight.

Plant conmunities.--Records of plants associated with Nitella acuminata were limited for the most part to other charophytes (Table 6). Very few vascular plants grew in close association with the species. 


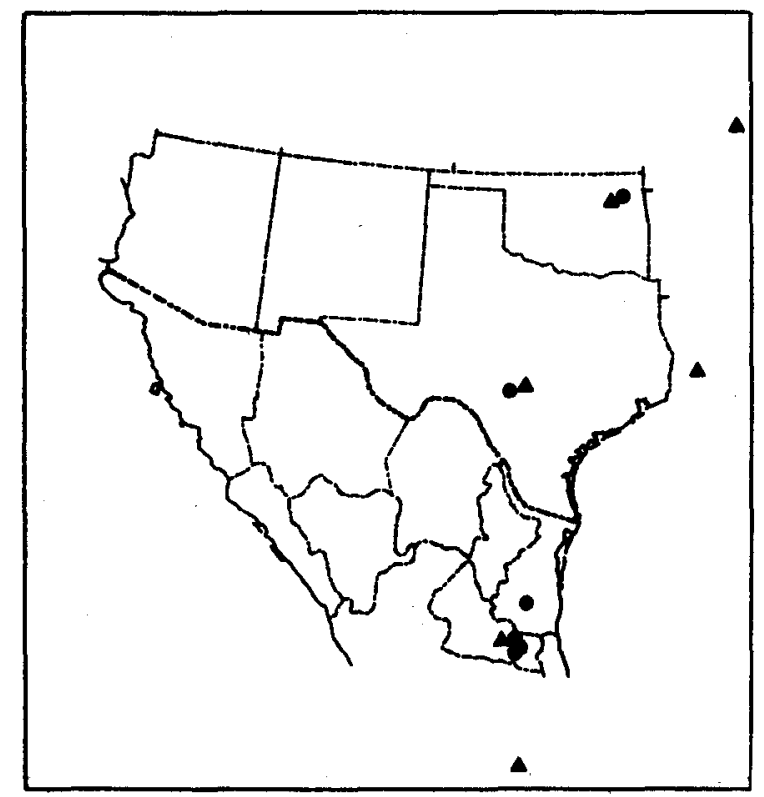

Fig. 15. Distribution of Nitella acuminata in the study area; localities examined during the present study, $\Delta$ localities reported in the literature. 
Table 5. Physicochemical features of habitats supporting Nitella acuminata.

\begin{tabular}{|c|c|c|c|c|c|c|c|c|c|c|c|}
\hline Specimens & Locality & $\mathrm{Habi}$ tat & Subs trate & Depth & $\begin{array}{l}\text { Tur- } \\
\text { bidi ty }\end{array}$ & Light & $\begin{array}{l}\text { Tempe } \\
\text { air }\end{array}$ & $\begin{array}{l}\text { rature } \\
\text { water }\end{array}$ & $\mathrm{pH}$ & Alk. & $\mathrm{CO}_{2}$ \\
\hline HCE 64-10 & Oklahoma & small pond & mud & $0.15-0.6$ & 0 & open & - & - & 7.3 & 58 & 5.0 \\
\hline $61-9-15-6$ & Texas & river & silt-mud & $0.10-0.3$ & 0 & open & 25.5 & 23.5 & 7.65 & 233 & 10.0 \\
\hline $61-9-10-2$ & Tamaulipas & 3 s tream & $\begin{array}{l}\text { silt- } \\
\text { gravel }\end{array}$ & $0.15-0.3$ & 0 & $\begin{array}{l}\text { open \& } \\
\text { shaded }\end{array}$ & 34.0 & 26.0 & 7.6 & 260 & 12.0 \\
\hline $61-9-9-1$ & $\begin{array}{l}\operatorname{San} \text { Luis } \\
\text { Potosi }\end{array}$ & stream pool & clay-mud & $0.10-0.25$ & 0 & open & 34.0 & 30.0 & 7.85 & 193 & 4.5 \\
\hline $61-9-8-5$ & $\begin{array}{r}\text { San Luis } \\
\text { Potosi }\end{array}$ & 8 tream & elay-marl & $0.15-0.2$ & 0 & open & 28.0 & 30.0 & 7.3 & 167 & 16.5 \\
\hline $63-1-25-1$ & $\begin{array}{l}\text { San Luis } \\
\text { Potosi }\end{array}$ & stream pool & $\begin{array}{l}\text { clay-mud- } \\
\text { silt }\end{array}$ & $0.10=0.3$ & 4 & open & 28.0 & 21.0 & 7.2 & 315 & 38.0 \\
\hline $6 I-9-8-3$ & $\begin{array}{l}\text { San Luis } \\
\text { Potosi }\end{array}$ & s tream & silt-mud & $0.20-0.4$ & 0 & $\begin{array}{l}\text { heavily } \\
\text { shaded }\end{array}$ & 33.0 & 27.0 & 7.4 & 208 & 16.5 \\
\hline
\end{tabular}


Table 6. Other charophytes found growing in association with Nitella acuminata.

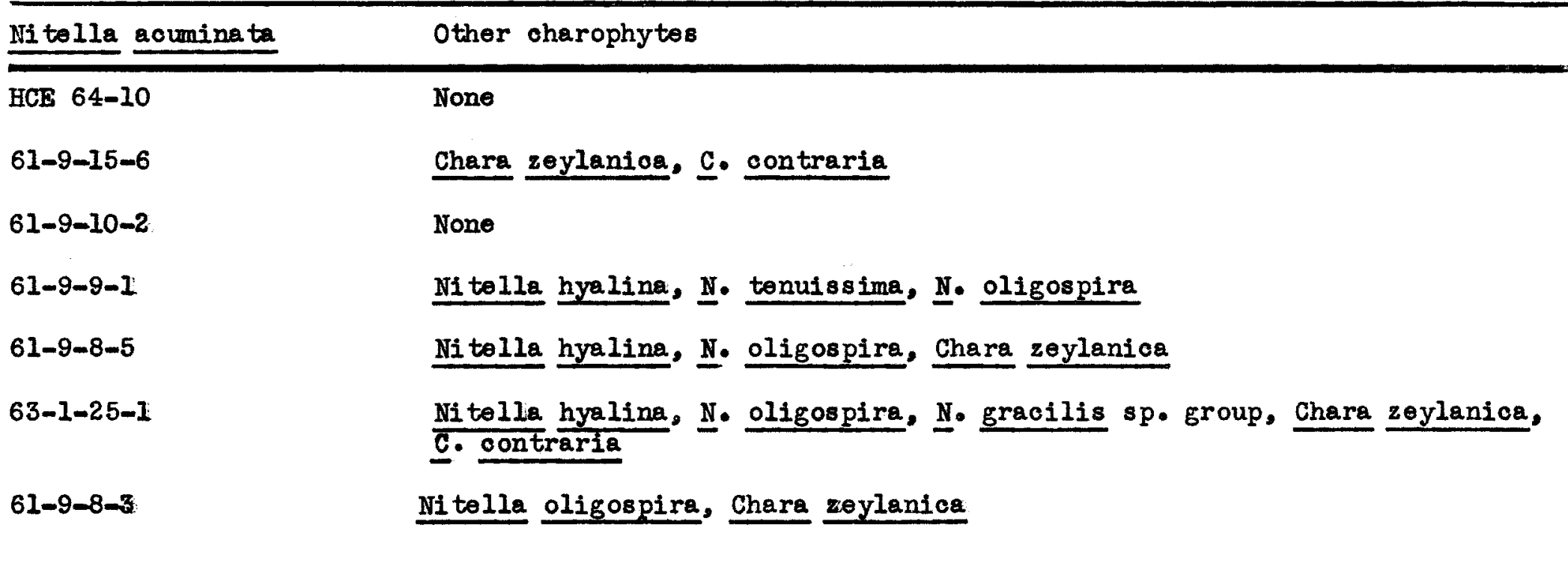


It was most frequently associated with N. oligospira, N. hyalina, and Chara zeylanica.

MORPHOLOGY, CYTOLOGY, AND TAXONOMY: The complete range of variation observed in Nitella acuminata from the study area is included in the description and is illustrated in Figures 12-14. Marked variations in vegetative morphology were limited to number and length of dactyls, and to the length of branchlets in terminal whorls and secondary branches (presence or absence of heads). Although differences in these characters were quite apparent between some specimens, when considered together, the specimens formed a more or less complete intergraded series (Table 7). The species displayed only minor variations in size of gametangia. The slightly compressed and distinctly stipitate antheridium characteristic of the present specimens has not been previously reported for the species. These characters may prove to be significant in respect to infraspecific taxa.

The oospores of the specimens from the study area were very consistent with regard to color, number of striae, D.E.A., and membrane decoration (Table 7). As were the gametangia, the oospores of specimens from Texas (61-9-15-6) were somewhat larger than those of the other specimens examined. It is interesting to note that the measurements of the oospores of the Texas plants are nearly identical to those recorded for $\mathrm{N}$. acuminata $\operatorname{var}$ lindheimeri from the same general area (Braun and Nordstedt, 1882). However, this character, alone, does not serve to distinguish the Texas specimens from others of the study area.

A chromosome number of 9 was counted in specimens from collections HCE $64-10,61-9-8-3,61-9-8-5,61-9-9-1$, and $61-9-15-6$. No variation in number was observed in any of these specimens. Hotchkiss (1958) reported 18 chromosomes for Nitella acuminata var. subglomerata from 
Tablo?. A collparison of specimens exanined during the present study and previously described specimens which are concluded to represont a single taxon, intelle peuelante.

\begin{tabular}{|c|c|c|c|c|c|c|c|c|c|c|c|c|c|c|c|}
\hline$S P E C$ I MEX & $\begin{array}{l}B \text { R A M } \\
\text { no. } \\
\end{array}$ & $\begin{array}{r}\text { CH L } \\
\text { dacty } \\
\text { no. }\end{array}$ & $\begin{array}{l}\text { E T S } \\
\text { yls } \\
\text { character }\end{array}$ & GENERAL HABIT & & $\begin{array}{l}00 \mathrm{G} O \mathrm{NI} \\
\text { length }\end{array}$ & Width & $\begin{array}{l}\text { c O R o N } \\
\text { leugth }\end{array}$ & $\begin{array}{l}\text { OI A } \\
\text { WIdth }\end{array}$ & $\begin{array}{l}\text { OOS P P O } \\
\text { length }\end{array}$ & Res & no. ridget & D.F.A. & mambrane & $\begin{array}{l}\text { ANTHERIDIA } \\
\text { diameter }\end{array}$ \\
\hline N. stellaris & $(6-) 8$ & $\begin{array}{r}(2-) \\
3-4 \\
(-5) \\
\end{array}$ & $\begin{array}{l}\text { short; acumi- } \\
\text { nate }\end{array}$ & 100ss heads & $\begin{array}{l}\mathrm{N} \\
\mathrm{R} \\
\mathrm{M} \\
\end{array}$ & - & - & - & - & $\begin{array}{l}10 \\
225-246 \\
235 \pm 2.8\end{array}$ & $\begin{array}{r}210-228 \\
223.1 .8 \\
\end{array}$ & $6-7$ & $\begin{array}{l}40-50 \\
46 \pm 1.1 \\
\end{array}$ & $\begin{array}{l}\text { finoly } \\
\text { grapulate }\end{array}$ & - \\
\hline $\begin{array}{l}\text { 1. Atellaris } \\
\text { Type deseription } \\
\text { Allon, } 1896\end{array}$ & 8 & $2-4$ & $\begin{array}{l}\text { short, stellate; } \\
\text { acuminate }\end{array}$ & - & & - & - & - & - & $230-240$ & 225 & $5-6$ & - & mooth & 215 \\
\hline 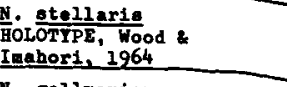 & $5-7$ & $2-5$ & $\begin{array}{l}\text { short \& elong- } \\
\text { ate; acuminate }\end{array}$ & no heads & & $285-300$ & $250-285$ & $38-42$ & $46-53$ & $230-245$ & $225-240$ & $(5-) 6(-7)$ & 46 & $\begin{array}{l}\text { granulate } \\
\text { or papiliate }\end{array}$ & $195-220$ \\
\hline 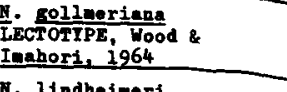 & $5-7$ & $2-4$ & $\begin{array}{l}\text { stellate \& } \\
\text { slightly olong- } \\
\text { atei acuinate } \\
\end{array}$ & $\begin{array}{l}\text { saull compact } \\
\text { heads }\end{array}$ & & $390-410$ & $330-345$ & $38-45$ & $52-60$ & $270-285$ i & n diam. & $6-7$ & 53 & $\begin{array}{l}\text { finely } \\
\text { granulate }\end{array}$ & $280-330$ \\
\hline $\begin{array}{l}\text { T. Iindheineri } \\
\text { Type description } \\
\text { Braun fordstedt, 2882 }\end{array}$ & $5-6$ & - & $\begin{array}{l}\text { - longate; acuni- } \\
\text { nate }\end{array}$ & - & & - & 一 & $\longrightarrow$ & - & $290-300$ & $240-260$ & $7-8$ & - & - & - \\
\hline $61-9-15-6$ & $8(-10)$ & $\begin{array}{r}(2-) \\
3-4\end{array}$ & $\begin{array}{l}\text { Elongate; } \\
\text { acuainate }\end{array}$ & compact heads & $\begin{array}{l}\mathrm{n} \\
\mathrm{R} \\
\mathrm{M} \\
\end{array}$ & $\begin{array}{l}15 \\
440-460 \\
446 \pm 2.2 \\
\end{array}$ & $\begin{array}{l}360-370 \\
364 \pm 1.4 \\
\end{array}$ & $\begin{array}{l}28-32 \\
30 * 0.6 \\
\end{array}$ & $\begin{array}{r}45-55 \\
48+1.2 \\
\end{array}$ & $\begin{array}{l}15 \\
260-280 \\
272 \pm 2.2 \\
\end{array}$ & $\begin{array}{r}240-260 \\
255+1.8 \\
\end{array}$ & $(6-) 7$ & $\begin{array}{l}40-55 \\
46 \pm 1.4 \\
\end{array}$ & $\begin{array}{l}\text { Einely } \\
\text { granulate }\end{array}$ & $\begin{array}{l}15 \\
290-325 \\
309+2.8 \\
\end{array}$ \\
\hline $61-9-10-2$ & $\begin{array}{r}(6-) \\
8 \\
(-10,) \\
\end{array}$ & $\begin{array}{r}(2-) \\
3 \\
(-4) \\
\end{array}$ & $\begin{array}{l}\text { - longate \& } \\
\text { stollate; } \\
\text { acuaniagte } \\
\end{array}$ & no heads & $\begin{array}{l}\mathrm{N} \\
\mathrm{B} \\
\end{array}$ & - & - & - & - & - & - & - & - & $\longrightarrow$ & $\begin{array}{l}20 \\
220-270 \\
250 \pm 4.2 \\
\end{array}$ \\
\hline $61-9-9-1$ & $\begin{array}{r}(6-) \\
8 \\
(-9) \\
\end{array}$ & $\begin{array}{r}(2-) \\
3-4 \\
(-6) \\
\end{array}$ & $\begin{array}{l}\text { elongate; } \\
\text { acuninate }\end{array}$ & compact heada & $\begin{array}{l}\mathrm{N} \\
\mathrm{R} \\
\mathrm{R} \\
\end{array}$ & $\begin{array}{l}8 \\
350-392 \\
364 \pm 5.7 \\
\end{array}$ & $\begin{array}{l}280-300 \\
292+3.4 \\
\end{array}$ & $\begin{array}{l}21-28 \\
24 \div 0.9 \\
\end{array}$ & $\begin{array}{l}40-45 \\
4100.7\end{array}$ & $\begin{array}{l}13 \\
210-252 \\
227 \cdot 3,2 \\
\end{array}$ & $\begin{array}{r}190-238 \\
205+3.5 \\
\end{array}$ & $(6-) 7$ & $\begin{array}{l}33-49 \\
41<1.2 \\
\end{array}$ & $\begin{array}{l}\text { finely } \\
\text { granulate }\end{array}$ & $\begin{array}{l}10 \\
220-295 \\
266+8.2 \\
\end{array}$ \\
\hline $61-9-8-5$ & $\begin{array}{r}(6-) \\
8 \\
(-20) \\
\end{array}$ & $\begin{array}{r}(2-) \\
3-4 \\
(-5) \\
\end{array}$ & $\begin{array}{l}\text { elongate; } \\
\text { acuninate }\end{array}$ & compact heads & $\begin{array}{l}\mathbf{N} \\
\mathbf{R} \\
\mathbf{M} \\
\end{array}$ & $\begin{array}{l}10 \\
320-390 \\
369+5.1 \\
\end{array}$ & $\begin{array}{l}265-320 \\
282 \pm 4.1 \\
\end{array}$ & $\begin{array}{l}24-35 \\
29<0.8 \\
\end{array}$ & $37-55$ & $\begin{array}{l}20 \\
208-260 \\
248+1.5 \\
\end{array}$ & $\begin{array}{r}195-238 \\
230 \pm 3.2 \\
\end{array}$ & $6-7$ & $\begin{array}{r}36-46 \\
4100.6 \\
\end{array}$ & $\begin{array}{l}\text { Sinely } \\
\text { granulate }\end{array}$ & $\begin{array}{l}10 \\
290-260 \\
221+8.9 \\
\end{array}$ \\
\hline $63-1-25-1$ & $\begin{array}{c}(6-) \\
8 \\
(-10) \\
\end{array}$ & $2-3$ & $\begin{array}{l}\text {-longate; } \\
\text { acuufnete }\end{array}$ & compact heads & $\begin{array}{l}N \\
R \\
M \\
\end{array}$ & $\begin{array}{l}10 \\
405-435 \\
422 * 2.9 \\
\end{array}$ & $\begin{array}{r}300-339 \\
323 \pm 3.8 \\
\end{array}$ & $\begin{array}{l}32-36 \\
34 \neq 0.5\end{array}$ & $\begin{array}{l}47-66 \\
53+1.8 \\
\end{array}$ & $\begin{array}{l}15 \\
240-262 \\
250+1.6 \\
\end{array}$ & $\begin{array}{r}220-240 \\
232.1 .7 \\
\end{array}$ & 6 & $\begin{array}{l}40-61 \\
48+1.8 \\
\end{array}$ & $\begin{array}{l}\text { finoly } \\
\text { granulate }\end{array}$ & $\begin{array}{l}15 \\
210-255 \\
239+3.2 \\
\end{array}$ \\
\hline N. maxicana & $(6-) 8$ & $\begin{array}{r}(2-) \\
4-5\end{array}$ & $\begin{array}{l}\text { stellate } \\
\text { slightly elong- } \\
\text { atei acueinate }\end{array}$ & no heads & $\begin{array}{l}\mathrm{N} \\
\mathrm{R} \\
\mathrm{N} \\
\end{array}$ & $\begin{array}{l}10 \\
360-395 \\
37564.1\end{array}$ & $\begin{array}{r}275-300 \\
289-2.9 \\
\end{array}$ & $\begin{array}{l}18-28 \\
25 * 1.1\end{array}$ & $\begin{array}{r}36-50 \\
44 \pm 4.4 \\
\end{array}$ & $\begin{array}{l}10 \\
220-245 \\
230 \pm 2.7 \\
\end{array}$ & $\begin{array}{r}190-210 \\
199 \pm 2.7 \\
\end{array}$ & $(6-) ?$ & $\begin{array}{r}37-43 \\
40.0 .6 \\
\end{array}$ & frnoly & $\begin{array}{l}10 \\
250-290 \\
269 \pm 5.6 \\
\end{array}$ \\
\hline 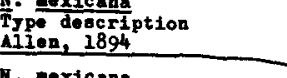 & 8 & $2-3$ & $\begin{array}{l}\text { - longate; } \\
\text { opicuiate }\end{array}$ & Do hoads & & - & 一 & - & - & 275 & 230 & 5 & - & granular & 245 \\
\hline 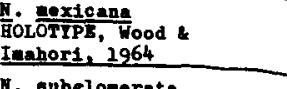 & $6-7$ & $1-3$ & $\begin{array}{l}\text { - longete; acute } \\
\text { or acuminate }\end{array}$ & no heads & & $345-360$ & $285-315$ & $42-46$ & $70-72$ & $258-285$ & $225-230$ & 7 & 52 & $\begin{array}{l}\text { finely } \\
\text { granulate }\end{array}$ & $245-270$ \\
\hline$\frac{\mathrm{N}}{\mathrm{Mi}} \frac{\text { subshonerate }}{1892}$ & $6-8$ & $2-4$ & $\begin{array}{l}\text { elongate: } \\
\text { acuminate }\end{array}$ & loowe heads & & - & 一 & 一 & - & 275 & 240 & $6-7$ & - & - & 300 \\
\hline 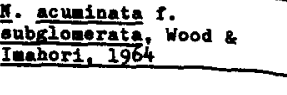 & $6-7$ & $2-3$ & $\begin{array}{l}\text {-longate; } \\
\text { acuantrate }\end{array}$ & 100ase heads & & $315-390$ & $240-285$ & $52-58$ & $60-68$ & $240-285$ & $225-250$ & $6-7$ & $49-56$ & $\begin{array}{l}\text { suooth or } \\
\text { finoly } \\
\text { granulate }\end{array}$ & $280-315$ \\
\hline
\end{tabular}


Kentucky. Imahori and Kato (1961) reported the same number for that variety from Japan. A chromosome number of 18 also was reported for var. capitulifera from Japan (Sasaki, 1960). Sarma and Khan (1964) reported 18 chromosomes in an u determined variety of ‥ acuminata from India. Chromosome counts of 18 have also been made in the species (N. acuminata var. belangeri vide Wood, 1954) from Lake Mattamuskeet, North Carolina. It is quite apparent that polyploidy has occurred, and may be occurring, in the N. acuminata complex. At this time, only speculations regarding the significance of this polyploidy can be presented.

For all practical purposes, a chromosome number of 9 can be considered as basic for the species complex. Chromosome numbers of 3 , 6, and/or 12 may have contributed to the original establishment of the 9 number, but this appears to be of little significance regarding the present evolutionary state of the species. The regular occurrence of N. acuminata with 9 chromosomes in more southern regions of North America and the occurrence of nearly identical plants in Kentucky and North Carolina with 18 chromosomes suggest two possibilities: (1) that the 18 chromosome number merely represents a type of polyploidy that has accompanied the northern advancement of the species, or (2) that the 18-chromosome plants represent an allopolyploid resulting from hybridization between the 9-chromosome plants in the south and a hypothetical 9-chromosome plant in the north. The latter hypothesis is in accord with the known variation in norphology within the species complex. Specimens examined during the present study are arranged in Table 7 according to their north-south occurrence. Various data on specimens previously reported from or in the vicinity of the study area are also included in the table. Reference is made to each of the latter specimens according to their apparent relationship to specimens of the present study. 
Based on data included in Table 7 and the distribution shown in Figure 14, it appears that specimens described as Nitella stellaris, N. Iindheimeri, N. mexicana, N. gollmeriana (described from Venezuela and also reported from the West Indies), specimens from the study area identified as $\underline{N}$. subglomerata (or var.), and possibly the more northern N. Subspicata constitute a rather narrow intergraded series which should be included in a single subgroup of the ‥ acuminata complex.

Nitella glomerulifera is the only form of this type described from North or South America that does not blend well with the present forms. It has long been known that $\underline{N}$. subglomerata displays a more southern distribution in North America, whereas $\mathrm{N}$. glomerulifera is more northern (Allen, 1892). This general pattern of distribution indicates that there may be at least two major infraspecific taxa in the species complex in North America. However, the occurrence of forms representing the "glomerulifera type" in the south and the "subglomerata type" in the north, and the occurrence of apparent intergrades in various areas indicate that a certain amount of hybridization has occurred. Since the taxonomy of this complex is by no means resolved, the present specimens are not assigned a particular subgroup name in the N. acuminata complex. However, many of the previously described species included in Table 7 represent forms of $\underline{\mathrm{N}}$. acuminata var. acuminata in Wood's revision (Wood and Imahori, 1964). 
NITELLA CLAVATA Kützing

Figure 16

Nitella clavata Kützing (1849:518).

N. translucens Halsted (1879:175 ex parte, vide Wood, 1948).

IITERATURE FOR THE STUDY AREA: Braun and Nordstedt (1882),

Nordstedt (1889), Allen (1894), Wood (1948), Horn af Rantzien (1950), Allen (1954) and Hevly (1961). See also Williams (1892), Daily (1944), and Allen (1951).

DESCRIPTION OF SPECIMFNS (including 5 plants from each collection): Plants monoecious, 6.0 (very young) to $60.0 \mathrm{~cm}$ high, usually with distinct terminal and axillary heads composed of 3-4 whorls of branchlets and associated secondary branches, bright to dark green, moderately incrusted with lime in very distinct bands. Main axes 620-1160 $\mu$ in diameter; internode length to $13.0 \mathrm{~cm}$, greatly exceeding or shorter than branchlet length. Branchlets of 2 types: PRDMARY BRANCHLETS (4-) 6-7 in a whorl, ranging from a few $\mathrm{mm}$ (in heads) to $5.5 \mathrm{~cm}$ long (in expanded whorls), usually l-furcate but frequently simple on older parts of plants; primary rays $1 / 2-4 / 5$ branchlet length in expanded whorls but length of ultimate rays (dactyls) greatly exceeds that of primary rays in the heads. Ultimate rays 1 -celled, (2-) 3-4 (-5) at a node, slightly or much inflated to $1300 \mu$ in diameter, abruptly acuminate. ACCESSORY BRANCHLETS simple, (4-) 5-7 (-9) at a node, usually below (occasionally above) appearing to alternate with primary branchlets, ranging from a few $\mathrm{mm}$ (in heads) to $3.0 \mathrm{~cm}$ (in expanded whorls) long, slightly or much inflated, distinctly acuminate. Branches 2-3, elongate or contracted into heads. Gametangia conjoined at branchlet nodes (most abundant in heads). Oogonia 2-4 at a node, 520-600 $\mu$ Iong, 420-450 $\mu$ wide; coronulae persistent, 47-61 $\mu$ high, 65-83 $\mu$ wide. Oospores medium brown to dark chestnut brown, 335-380 $\mu$ 1ong, 315-375 $\mu$ 
Figure 16. Nitella clavata. A. Terminal whorls of branchlets of mature plant (63-8-8-1); note simple primary branchlets and accessory branchlets above and below primary branchlets, X 2.5. B. Terminal whorls of branchlets of mature plant (64-8-30-3), X 2.5. C. Habit sketch of mature plant (64-8-30-3), X 1/2. D. Characteristic branchlet of fertile heads (64-830-4), X 10. E. Upper whonls of branchlets of a mature plant (61-9-1-4), X 2.5. F. Characteristic branchlet of fertile heads (61-9-1-4), X 10 . 

wide; striae of 7 (-8) ridges; D.E.A. 47-68 $\mu$; membrane regularly granulate or coarsely granulate. Antheridia solitary, 330-510 u in diameter, 8-scutate.

SPECIMENS EXAMINED: ARTONA: (64-8-30-3) Large spring fed lake, $1 \mathrm{mi}$. B Vernon intersection on U.S. Hwy 60, Apache Co., Arizona, D. Tindall and A. Hotchkiss, Aug. 30, 1964. (64-9-8-2) Small shallow tank, near entrance to Apache Cove, 1 mi. N Iakeside, State Hwy 173, Navajo Co., Arizona, D. Tindall and A. Hotchkiss, Sopt. 8, 1964. (W1 928 and 64-9-1-4) Concrete tank, Dugans Spring, Sycamore Canyon Picnic Area, 9 mi. by road W Pena Blanca Lake, Coronado National Forest, Santa Cruz Co., Arizona, W. Minckley, May 2, 1964; D. Tindall, A. Hotchkiss, and W. Minckley, Sept. 1, 1964.

DURANGO: (63-8-8-1) In swift current of the Rio Chico, $17.5 \mathrm{mi}$. W Darango, Mex. Hwy 40 (just below bridge), Durango, Mexico (elevation ca. $6000 \mathrm{ft})$, D. and Patricia Tindal1, Aug. 8, 1963. (63-8-8-3) Quarry pond, $2.6 \mathrm{mi}$. W Rio Chico, Mex. Hwy 40, Durango, Mexico, D. and Patricia Tindall, Aug. 8, 1963.

TYPE LOCALITY: Brazil (Kützing, 1849).

DISTRIBUTION: Nitella clavata occupies a wide geographical range in North and South America, extending north into British Columbia (Allen, 1951) and south into Argentina and Chile (Braun and Nordstedt, 1882). Localities of the species in North America other than those of the study area include British Columbia (Allen, 1951), Montana (Williams, 1892; Allen, 1894), Oregon (Allen, loc. cit.), California (Braun and Nordstedt, 1882; Allen, 1894), Nebraska (Daily, 1944), and Missouri (Braun and Nordstedt, 1882; Allen 1894). Countries in South America from which the species has been recorded include Brazil, Bolivia, Peru, Uruguay, Argentina, and Chile (reviewed by Horn af Rantzien, 
1950). H. and J. Groves (1911) reported the species from the Dominican Republic.

The distribution of $\mathrm{N}$. clavata in the study area is shown in Figure 17. Previous records of the species include those from New Mexico (Braun and Nordstedt, 1882), Arizona (Hevly, 1961), Chihuahua (Wood, 1948), San Luis Potosi (AIIen, 1894), Mexico, Morelos, and Vera Cruz (Braun and Nordstedt, 1882).

The distribution of $\mathbb{N}$. clavata shows a close correlation with the highland areas of North and South America. The species has been recorded at an elevation of $4270 \mathrm{~m}$ in Peru (Braun and Nordstedt, 1882).

BCOLOGY: Physicochemical features of the habitats.--Various features of the habitats supporting Nitella clavata in the study area are included in Table 8 . The types of habitat observed were quite different but the parts of the habitats supporting the species were distinctly similar with regard to substrate, depth, light conditions, and temperature. The species occurred in waters characterized by a relatively wide range of $\mathrm{pH}(7.6$ to 10.0$)$ and alkalinity $42-170 \mathrm{mg} / \mathrm{l})$, and very small concentrations or a complete lack of free carbon dioxide. Plant communities.-Nitella clavata, N. missouriensis, and Chara globularis occurred as isolated tufts scattered throughout a dense zone of $\underline{\mathrm{C}}$. braunii in the spring-fed lake locality of Apache County, Arizona. A similar association, excluding C. braunii, was observed in both habitats in Navajo County, Arizona. Chara braunii was sparsely distributed throughout extensive stands of Nitella clavata in both Mexican Iocalities. The spring-fed concrete tank locality in Santa Cruz County, Arizona, supported only N. clavata; however, a similar, but smaller, concrete tank in the same area supported a luxuriant stand of Chara braunii. 


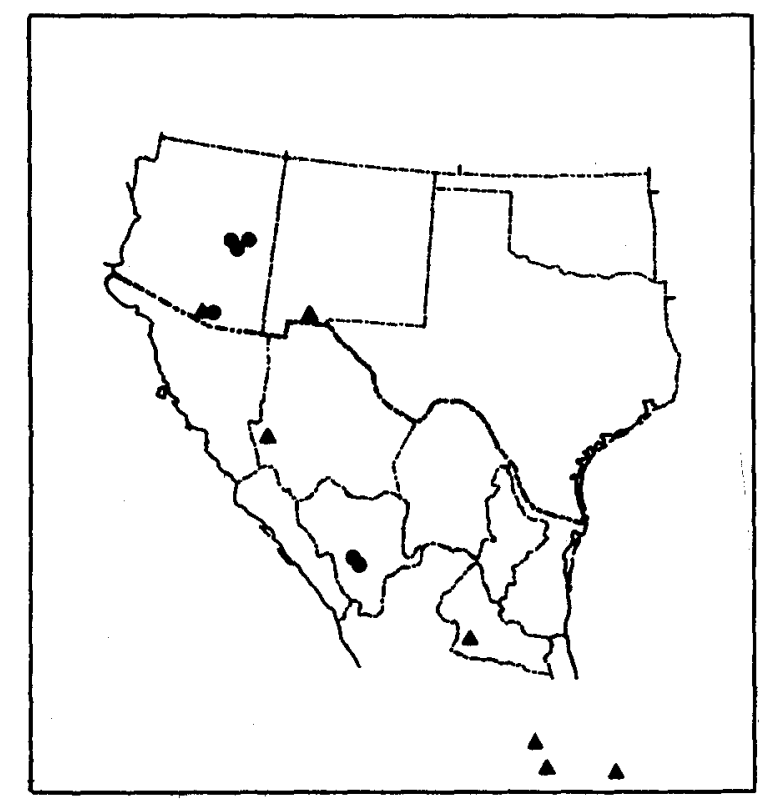

Fig. 17. Distribution of Nitella clavata in the study area; localities examined during the present study, $\Delta$ localities reported in the literature. 
Table 8. Physicochemical features of the habitats supporting Nitella clavata.

\begin{tabular}{|c|c|c|c|c|c|c|c|c|c|c|c|}
\hline Speoimens & Locality & Habitat & Substrate & Depth & $\begin{array}{l}\text { Tur- } \\
\text { bidity }\end{array}$ & Light & $\begin{array}{l}\text { Tempe } \\
\text { air }\end{array}$ & $\begin{array}{l}\text { rature } \\
\text { water }\end{array}$ & $\mathrm{pH}$ & Alk. & $\mathrm{CO}_{2}$ \\
\hline $64-8-30-3$ & Arizone & $\begin{array}{l}\text { spring-fed } \\
\text { lake }\end{array}$ & mud-sand & $0.20-0.3$ & 0 & open & 26.0 & $\begin{array}{l}20.0- \\
23.0\end{array}$ & $\begin{array}{c}9.4- \\
10.0\end{array}$ & 102 & 0.0 \\
\hline $61-9-1-4$ & Arizona & $\begin{array}{l}\text { spring }=\text { fed } \\
\text { concrete } \\
\text { tank }\end{array}$ & $\begin{array}{l}\text { grave } 1- \\
\text { sand-mud }\end{array}$ & $1.00-2.5$ & 0 & $\begin{array}{l}\text { partly } \\
\text { shaded }\end{array}$ & 32.0 & $\begin{array}{l}20.0- \\
25.0\end{array}$ & $\begin{array}{l}7.6- \\
8.3\end{array}$ & $\begin{array}{l}160- \\
170\end{array}$ & $\begin{array}{l}8.0- \\
0.0\end{array}$ \\
\hline $64-9-8-2$ & Arizona & small tank & sand-mud & $0.20-0.3$ & + & open & 24.0 & 24.0 & 7.8 & 148 & 4.5 \\
\hline $64-9-8-4$ & Arizona & $\begin{array}{l}\text { small arti- } \\
\text { ficial lake }\end{array}$ & sand-mud & $0.05-0.2$ & + & open & 26.5 & 24.0 & 8.2 & 129 & 1.0 \\
\hline $63-8-8-1$ & Durango & $\begin{array}{l}\text { swiftly flow- } \\
\text { ing river }\end{array}$ & $\begin{array}{l}\text { sand- } \\
\text { gravel }\end{array}$ & $0.10-0.2$ & 0 & open & 22.0 & 21.0 & 8.0 & 42 & 0.5 \\
\hline $63-8-8-3$ & Durango & quarry pond & $\begin{array}{l}\text { grave } 1- \\
\text { sand }\end{array}$ & $0.10-0.3$ & 0 & open & 19.0 & 22.5 & 9.4 & 43 & 0.0 \\
\hline
\end{tabular}

Table 9. A comparison of gametangia and oospores of attenuated and inflated forms of Nitella clavata.

\begin{tabular}{|c|c|c|c|c|c|c|c|c|c|c|c|}
\hline SPEC IMENS & & $\begin{array}{l}00 \mathrm{G} 0 \\
\text { leng th }\end{array}$ & $\begin{array}{l}\text { N I A } \\
\text { width }\end{array}$ & $\begin{array}{l}\text { CORONUL } \\
\text { height }\end{array}$ & width & $\begin{array}{l}0 \text { o S P } \\
\text { long th }\end{array}$ & $\begin{array}{l}\text { ORE S } \\
\text { width }\end{array}$ & ridges & $D \cdot \mathbf{E} \cdot \mathbf{A}$. & membrane & $\begin{array}{l}\text { THERIDIA } \\
\text { diame tor }\end{array}$ \\
\hline $\begin{array}{l}64-8-30-3 \\
\text { (attenuated) }\end{array}$ & $\begin{array}{l}\mathrm{N} \\
\mathrm{R} \\
\mathbf{M}\end{array}$ & $\begin{array}{l}5 \\
530-555 \\
542 \pm 4.5\end{array}$ & $\begin{array}{l}420-450 \\
439 \pm 6.2\end{array}$ & $\begin{array}{l}54-61 \\
58 \pm 1.7\end{array}$ & $\begin{array}{l}76-83 \\
78 \pm 1.5\end{array}$ & $\begin{array}{l}15 \\
335-375 \\
354 \pm 2.9\end{array}$ & $\begin{array}{l}330-375 \\
359 \pm 3.6\end{array}$ & $7-8$ & $\begin{array}{l}54-68 \\
60 \pm 1.1\end{array}$ & granulate & $\begin{array}{l}25 \\
435-510 \\
471 \$ 4.2\end{array}$ \\
\hline $\begin{array}{l}64-9-1-4 \\
\text { (inflated) }\end{array}$ & $\begin{array}{l}\mathrm{N} \\
\mathrm{R} \\
\mathrm{M}\end{array}$ & $\begin{array}{l}16 \\
520-600 \\
560 \pm 4.7\end{array}$ & $\begin{array}{l}425-450 \\
443 \div 2 \cdot 4\end{array}$ & $\begin{array}{l}47-58 \\
52+1.2\end{array}$ & $65-76$ & $\begin{array}{l}30 \\
345-380 \\
353 \pm 1.9\end{array}$ & $\begin{array}{l}323-345 \\
336 \pm 1.9\end{array}$ & $7-8$ & $47-67$ & $\begin{array}{l}\text { coarsely } \\
\text { granulato }\end{array}$ & $\begin{array}{l}15 \\
330-405 \\
366 \$ 6.0\end{array}$ \\
\hline
\end{tabular}


Other plants associated with Nitelle clavata are included in the discussions of Chara braunii and $\underline{C}$. globularis.

MORPHOLOGY, CYTOLOGY, AND TAXONOMY: Considerable variation was observed among the specimens of Nitella clavata from the study area. Most of the specimens displayed more or less attenuated dactyls and accessory branchlets (Fig. 16A-D) but these structures were short and markedly inflated on specimens of collection 64-9-1-4 (Fig. $16 \mathrm{E}, \mathrm{F}$ ). Plants of the latter type usually have been referred to as var. inflata A. Br. Specimens collected in May 1964 from the same habitat as collection 64-9-1-4 displayed a much less inflated condition, tending more in the direction of the majority of specimens from the study area.

A comparison of fertile representatives of each form is included in Table 9. The marked similarity in size of gametangla and the occurrence of attenuated specimens in the same habitat as the inflated ones prevent separation of the two forms into infraspecific taxa.

A chromosome number of 18 was determined for specimens from collections $64-8-30-3$ and $64-9-4-1$. The chromosome number of this species has not been reported in the literature; however, Hotchkiss (unpublished) has observed chromosome numbers of 18 in Nitella clavata from Califormia, North Carolina (?) (unknown locality, possibly Florida, in culture at laboratory of L. A. Whitford, North Carolina State College, Raleigh), and Quebec (in culture, University of Louisville).

Nitella clavata is readily distinguished from all other charophytes in the study area by its once-furcate primary and simple accessory branchlets. Its closest relativo in the study area, N. acuminata, sometimes produces simple adventitious branchlets, but always above the primary ones, whereas the accessories of $\underline{N}$. clavata are normally below and alternating with the primaries. The tendency of various structures of $\underline{\mathrm{N}}$ clavata to become inflated further distinguishes it from $\underline{\mathrm{N}}$. acuminata. 


\section{NITELLA OLIGOSPIRA Braun}

Figure 18

Nitella oligospira Braun (1859:357).

N. oligospira var. wrightii Braun

N. furcata subsp. mucronata f. oligospira Wood (Wood and Imahori, 1964).

LITERATURE FOR THE STUDY AREA: Bram (1859), Braun and Nordstedt (1882), Wood (1948), and Allen (1954). See also Allen (1896), H. and J.

Groves (1911), Horm af Rantzien (1950), Daily and Kiener (1956), and Wood and Imahori (1964).

DESCRIPTION OF SPEC IMENS (including 5 specimens each from collections 61-9-8-2, 61-9-8-7B, and 63-1-25-7): Plants monoecious, 8-20 cm high, spreading, not forming heads, medium green to bright green, lightly to heavily incrusted with 1ime. Main axes 450-500 $\mu$ in diameter; internodes to $2.8 \mathrm{~cm}$ long, 1-1 $1 / 3$ branchlet length on lower axes. Branchlets not differentiated into fertile and sterile types, (5-) 6 in a whorl, to 1.8 cm long, at least partially 4-furcate; primary rays ca. $1 / 3$ branchlet length, $3.7-8.8 \mathrm{~mm}$ long, 210-395 $\mu$ in diameter; secondary rays 5-6 at a node (including percurrent ray), 1/4-1/3 branchlet length, 2.2-6.3 $\mathrm{mm}$ long, $145-350 \mu$ in diameter; tertiary rays (2, 3-) $4(-5)$ at a node, frequently simple, $1.0-4.0(-7.0) \mathrm{mm}$ long (longer ones simple), 135-280 $\mu$ in diameter; quaternary rays (1,2-) 3-4 when present (1-3-celled tertiary ray), frequently I-2 of these are short mucro-like cells, normal ones simple or forked, $1.0-4.0 \mathrm{~mm}$ 1ong, 70-196 $\mu$ in diameter; quinary rays (1-) $2(-4)$ when present (1-3-celled quaternary ray), as 2-celled dactyl or short mucro-like cell, normal ones 0.2-1.5 m long, 58-125 $\mu$ in diameter. Ultimate rays (excluding mucro-like rays) of unequal length, 2(-3)-celled; penultimate cell 58-155 $\boldsymbol{\mu}$ in diameter, tapering abruptly to base of macro; ultimate cell forming a conical macro (sometimes deciduous), 55-120 $\mu$ long, 
Figure 18. Nitella oligospira. A. Fertile shoot in axes of secondary branchlet rays (63-1-25-7), X 10. B. Mature fertile branchlet (63-1-257), X 10. C. Ultimate branchlet ray with characteristic mucro (63-1-257), $X 275$. D. Terminal furcation of branchlet displaying l-celled (mucro-like) ultimate rays $(61-9-8-2)$, X 50. E. Mature branchlet from lower part of plant (61-9-8-2), X 10. F. Terminal whorls of branchlets with antheridia (61-9-8-2), X 25. 


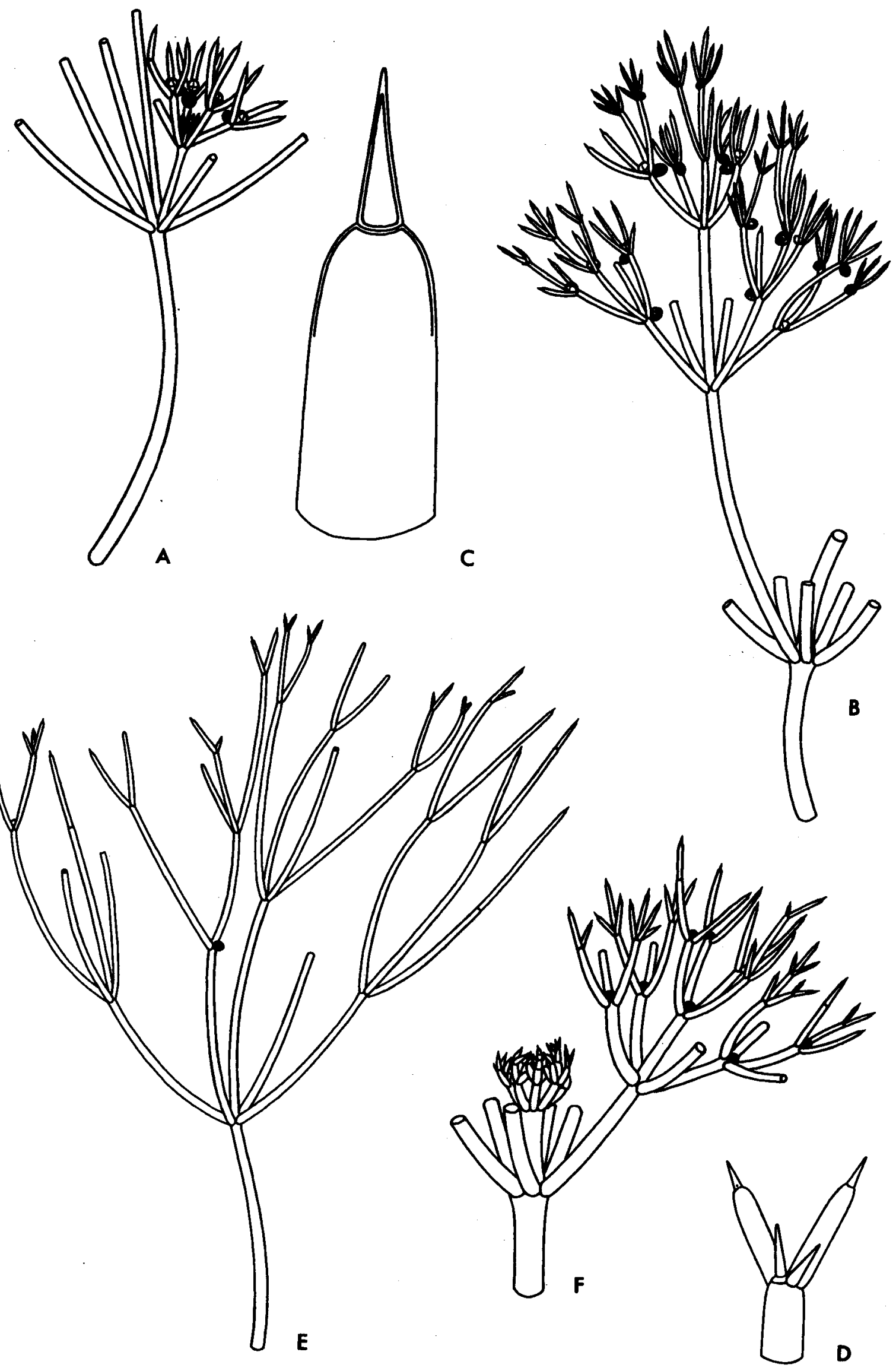


25-35 $\mu$ in diameter at base. Gametangia solitary or conjoined at and and $3 \mathrm{rd}$ branchlet nodes (rarely at lst node), fertile shoot frequently present at lst node, to $2.0 \mathrm{~mm}$ long. Oogonia solitary, 400-465 $\mu$ long, 320-350 $\mu$ wide; coronula persistent, 32-46 $\mu$ high, 60-70 $\mu$ wide. Oospores light golden-brown, 240-285 $\mu$ long, 225-263 $\mu$ wide; striae of $6(-7)$ low ridges; D.E.A. 46-58 $\mu$; membrane reticulate, usually completely formed, 12-20 meshes across fossa. Antheridia solitary, 240-308 $\mu$ in diameter, 8-scutate.

SPECTMRNS EXAMTNED: TEXAS (63-2-1-3 and 63-2-1-4 tent. det.) San Marcos River (small tufts in current), near public swiming area, San Marcos, Hays Co., Texas, D. Tindall and A. Hotchkiss, Feb. 2, 1963. TAMAULIPAS: (63-1-25-7) Arroyo, $16 \mathrm{mi} . \mathrm{S} \mathrm{Cd}$. Mante, Mex. Hwy 85, Tamaulipas, Mexico, D. Tindall and A. Hotchkiss, Jan. 25, 1963.

SAN LUIS POTOSI: (61-9-9-3D) Small limestone arroyo, flowing $W$, $31 \mathrm{mi}$. S Cd. Mante, Mex. Hwy 85, San Luis Potosi, Mexico, D. Tindall, A. Hotchkiss, and R. Goodyear, Sept. 9, 1961. (61-9-8-7B and 63-1-25-3) Small (Iimestone) arroyo, $17 \mathrm{mi}$. N Cd. Valles, Mex. Hwy 85, San Luis Potosi, Mexico, D. Tindall, A. Hotchkiss, and R. Goodyear, Sept. 8, 1961; D. Tindall and A. Hotchkiss, Jan. 25, 1963. (6I-9-8-2) First arroyo N Cd. Valles, near Palma Hotel, Mex. Hwy 85, San Luis Potosi, Mexico, D. Tindall, A. Hotchkiss, and R. Goodyear, Sept. 8, 1961.

TYPE LOCALITY: Brazil (Braun, 1859 fide Horn af Rantzien, 1950). DISTRIBUTION: Nitella oligospira is rather uncommon but displays a wide geographical range, occurring in Africa, Asia, Australia, North America, West Indies, and South America (Wood and Imahori, 1959). Records of the species for North America are very limited, being recorded from two localities in Texas (Leona and Comale Rivers, Braun and Nordstedt, 1882), one locality in Georgia (H. and J. Groves, 1911), and one locality in Nebraska (Daily and Kiener, 1956). South American and West Indian 
records of the species include those from Venezuela, Brazil, Cuba, Puerto Rico, and Trinidad (vide Horn af Rantzien, 1950, Allen, 1954).

The known distribution of the species in the study area is shown in Figure 19. Although limited, these records indicate a somewhat more common occurrence of the species than expected, and help bridge the large gap between the previously known localities of the species in North and South America. Although $\underline{\mathrm{N}}$. oligospira extends north into Nebraska, it shows a distinctly tropical distribution and should be regarded as a basically tropical form.

BCOLOGY: Physicochemical features of the habitats.--Nitella oligospira was observed only in open areas of limestone streams. Of the factors recorded for each of these habitats (Table 10), marked variation was observed only in rate of flow. The species flourished in moderately or swiftly flowing waters, whereas it represented a very insignificant part of the plant community in habitats characterized by still waters. The original records of the species from Texas also show it to be limited to runming waters (Braun and Nordstedt, 1882). This particular suitability to flowing waters may be correlated with a requirement for waters with a moderately alkaline $\mathrm{pH}$ and/or an abundance of free carbon dioxide. However, the extensive lime incrustation observed on some specimens indicates that the species can withstand periods of high $\mathrm{pH}$ and negligible amounts of free carbon dioxide.

Plant communities.--Nitella oligospira always occurred in close association with several other charophytes (Table 1I). Najas guadalupensis was the only vascular plant found to occur in association with the species.

MORPHOLOGY, CYTOLOGY, AND TAXONONY: Most of the specimens of Nitella oligospira examined during this study displayed relatively 


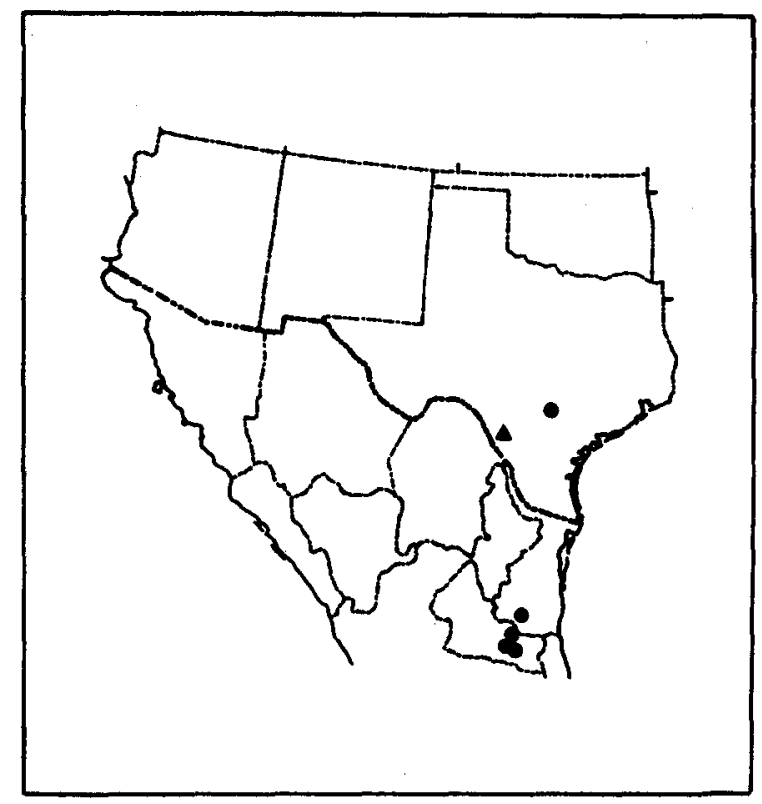

Fig. 19. Distribution of Nitella oligospira

in the study area; localities examined during the present study, $\triangle$ locality reported in the Iiterature. 
Table 10. Physicochemical features of the habitats supporting Nitella oligospira.

\begin{tabular}{|c|c|c|c|c|c|c|c|c|c|c|}
\hline Spec1mens & Locality & Habi tat & substrate & Turbidity & Light & $\begin{array}{l}\text { Tompe } \\
\text { air }\end{array}$ & $\begin{array}{l}\text { rature } \\
\text { water }\end{array}$ & $\mathrm{pH}$ & Alk. & $\mathrm{CO}_{2}$ \\
\hline $63-2-1-3$ & Texas & $\begin{array}{l}\text { swiftly flow- } \\
\text { ing stream }\end{array}$ & sand-gravel & 0 & open & - & $\begin{array}{l}21 \cdot 6- \\
23 \cdot 2\end{array}$ & $\begin{array}{l}7.3= \\
7.5\end{array}$ & $\begin{array}{l}270- \\
260\end{array}$ & $\begin{array}{l}26.5- \\
16.5\end{array}$ \\
\hline $63-1-25-7$ & Tamaulipas & $\begin{array}{l}\text { moderately } \\
\text { flowing s tream }\end{array}$ & marl & 0 & open & 25.0 & 20.0 & 7.3 & 162 & 15.0 \\
\hline $61-9-9-3 D$ & $\begin{array}{l}\text { San Luis } \\
\text { Potosi }\end{array}$ & stream pool & marl-organic & 0 & open & 34.0 & 30.0 & 7.85 & 193 & 6.0 \\
\hline $61-9-8-7 B$ & $\begin{array}{l}\operatorname{san} \text { Luis } \\
\text { Potosi }\end{array}$ & $\begin{array}{l}\text { stream pool } \\
\text { (slight flow) }\end{array}$ & $\operatorname{mar} I$ & 0 & open & 28.0 & 30.0 & 7.3 & 167 & 16.0 \\
\hline $63-1-25-3$ & $\begin{array}{l}\text { San Luis } \\
\text { Potosi }\end{array}$ & 8 tream pool & silt-mud & + & open & 28.0 & 21.0 & 7.2 & 315 & 38.0 \\
\hline $61-9-8-2$ & $\begin{array}{l}\text { San Luis } \\
\text { Potosi }\end{array}$ & $\begin{array}{l}\text { stream } \\
\text { (moderate flow) }\end{array}$ & )$^{\text {silt-marl }}$ & 0 & open & 33.0 & 27.0 & 7.4 & 208 & 16.5 \\
\hline
\end{tabular}


Table 11. Major components of plant communities containing Nitella oligospira.

\begin{tabular}{|c|c|}
\hline Nitella oligospira & Other plants \\
\hline $63-2-1-3$ (soattered tufts) & $\begin{array}{l}\text { Chara braunii (scattered tufts). C. globularis (scattered tufts). } \\
\text { C. contraria (rare tufts), Batrachospermum sp. (abundant tufts). Thorea sp. } \\
\text { Tabundant tufts). }\end{array}$ \\
\hline $63-1-25-7$ (abundant) & $\frac{\text { Nitella hyalina (abundant), } \mathbb{N} \text {. gracilis } \mathrm{sp} \cdot \text { group (abundant), Chara }}{\text { contraria (abundant). }}$ \\
\hline $61-9-9-3 D$ (rere) & 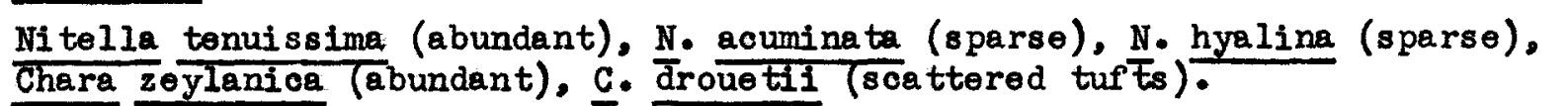 \\
\hline $61-9-8-7 B(\operatorname{rar} \theta)$ & $\frac{\text { Nitella hyalina }}{\text { (abundant). }}$ (abundant). N. acuminata (abundant), Chara zeylanica \\
\hline $63-1-25-3$ (rare) & 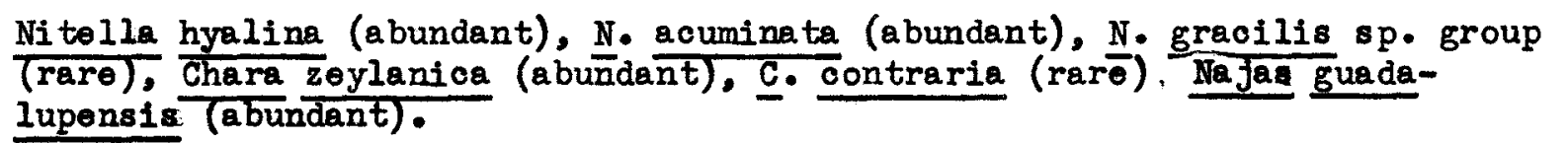 \\
\hline $61-9-8-2$ (abundant) & Nitella acuminata (abundant), Chara zeylanica (abundant), Najas guada- \\
\hline
\end{tabular}

Table 12. A comparison of gametangia and oospores of Nitella oligospira collected in September 1961 and January 1963 from the same general area in eastern Mexico.

\begin{tabular}{|c|c|c|c|c|c|c|c|c|c|c|}
\hline SPECIIAENS & & $\begin{array}{l}0 \circ G 0 \\
\text { length }\end{array}$ & $\begin{array}{l}\text { N I A } \\
\text { width }\end{array}$ & $\begin{array}{l}\text { C O R O } \\
\text { height }\end{array}$ & $\begin{array}{l}N \cup \mathcal{L} A \\
\text { width }\end{array}$ & $\begin{array}{l}00 \mathrm{~S} P \\
\text { leng th }\end{array}$ & $\begin{array}{c}\text { O R E S } \\
\text { width }\end{array}$ & ridges & $D \cdot E \cdot A$. & $\begin{array}{l}\text { ANTHERIDIA } \\
\text { diame ter }\end{array}$ \\
\hline $61-9-9-3$ & $\begin{array}{l}\mathrm{N} \\
\mathrm{R} \\
\mathrm{M}\end{array}$ & $\begin{array}{l}6 \\
400-410 \\
404 \pm 2.2\end{array}$ & $\begin{array}{l}325-340 \\
335 \pm 2.8\end{array}$ & $\begin{array}{l}32-46 \\
39 \pm 2.3\end{array}$ & $\begin{array}{l}60-66 \\
64 \pm 0.9\end{array}$ & $\begin{array}{l}6 \\
240-260 \\
249 \pm 3.6\end{array}$ & $\begin{array}{l}230-245 \\
236 \pm 2.6\end{array}$ & 6 & $\begin{array}{l}46-54 \\
50 \div 1.1\end{array}$ & $\begin{array}{l}11 \\
252-308 \\
285 \pm 5.6\end{array}$ \\
\hline $63-1-25-7$ & $\begin{array}{l}\mathrm{N} \\
\mathrm{R} \\
\mathrm{N}\end{array}$ & $\begin{array}{l}17 \\
420-465 \\
444+3.9\end{array}$ & $\begin{array}{l}320-350 \\
341 \pm 2.4\end{array}$ & $\begin{array}{l}32-45 \\
39 \pm 0.9\end{array}$ & $\begin{array}{l}61-70 \\
65 \pm 0.7\end{array}$ & $\begin{array}{l}22 \\
255-285 \\
270 \_1.3\end{array}$ & $\begin{array}{l}225-263 \\
241+2.3\end{array}$ & 607 & $\begin{array}{l}47-58 \\
52+0.7\end{array}$ & $\begin{array}{l}20 \\
240-290 \\
267+3.1\end{array}$ \\
\hline
\end{tabular}


consistent morphological features. Specimens collected from very swift waters of the San Mareos River (Hays Co., Texas) displayed a somewhat unusual character, thus are only tentatively included under this species. Otherwise, the occurrence of single-celled mucro-like ultimate bramchlot rays and small fertile shoots in the axes of socondary branchlet rays were the only features not common to all specimens. Of course, some specimens were sterile and others were fertile. A comparison of gametangia and oospores from collections made during different seasons illustrates the relative consistency of those structures (Table 12).

A chromosome number of 18 was determined for specimens from a single collection (61-9-8-2). This apparently is the first chromosome count for the species. However, the same number has been reported for several closely related species, including $\underline{N}$. mucronata (Gillet, 1959), ‥ microcarpa ssp. megacarpa (Hotchkiss, 1961; as N. megacampa. Tindall and Sawa, 1964), N. dictrosperma (Sarma and Khan, 1964), and N. furcata var. sjeberi (Hotchkiss in Wood, 1963 and as N. furcata, Hotchkiss, 1965). The name $N$. furcata $v a r$. sieberi represents the same taxon as N. microcarpa Braun (1859 vide Wood, 1963). Imahori and Kato (1961) reported chromosome numbers of 14 for $\mathrm{N}$. microcarpa, 24 and 48 for N. furcata, and 28 for N. shinii. All of these species show clear affinities with N. Oligospire but all of the chromosome numbers reported for them are peculiar to this section of the genus.

Nitella oligospira was recently combined with more than 50 previously recognized species to form a single large polytypic species which retained the name N. furcata (see Wood, 1962, 1963, 1964; Wood and Imahori, 1964). Much of the revision of the species group proposed by Wood appears to be well founded but the actual data supporting the 
treatment are not available, thus it cannot justifiably be followed at this time. It does appear, however, that $N$. oligospira may be required to yield its specific status to a closely related form which has nomenclatural priority.

Of particular interest along these lines are two species which inhabit portions of the Nitella oligospira range. Various forms of N. mucronata have been reported from New Mexico and Texas (Braun and Nordstedt, 1882). In fact, the species was recorded from the same rivers in Texas as was $\underline{N}$. Oligospira (the Leona and Comale rivers). Another closely related species, ‥ microcarpa, displays a wide distribution in the southern limits of the N. oligospira range, including sereral localities in the West Indies, Central America, and South America (see Horn af Rantzien, 1950). Nitella microcarpa is also known from a few localities in North America. Of interest with regard to the present study is a single collection from Louisiana (Braun and Nordstedt, 1882).

Although Nitella oligospira maecessarily be combined with other species, it appears to form a distinct taxon that should be classified at a higher rank than that of forma as proposed by Wood. 


\section{NITEIIA TENUISSTMA (Desvaux) Kattzing}

Figure 20

Chare tenuissima Desvaux (1809:313) vide Wood (1948). Mite11a tenuissima Kützing (1843:319).

LITERATURE FOR THE STUDY ARRA: Only literature pertaining to N. tenuissima var. compacta A. Br. is known for the study area (see below). DESCRIPTION OF SPECDIENS (including 5 mature plants): Plants monoecious, to $22 \mathrm{~cm}$ high, appearing fine and delicate but quite rigid, distinctly moniliform, light to modium green (grayish before lime is romoved), heavily incrusted with lime. Mnin axes to $195 \mu$ in diamoter; internode length mach exceeding that of branchlots. Branchlets consistently 6 in a whorl, at least partially 4-furcate, rays straight and profecting; primary rays 2.5-4.5 mm long, 69-84 $\mu$ in diameter; secondary rays $6(-7)$ at 2 node (including percurrent ray), 0.7-2.0 m long, 42-63 $\mu$ in diameter; tertiary rays $4-5$ at a node when fertile but frequently 6 at a node (including a percurrent ray) when sterile, $0.7-1.8 \mathrm{~mm}$ long, 35-50 $\mathrm{p}$ in diameter, frequently simple and 2-celled; quaternary rays (2-) 3-4 (-5) at a node, 0.6-1.9 mang, 28-44 $\mu$ in diameter, usually simple and 2-celled; quinary rays (present to some extent in all whorls) (2-) 3-4 (-5) at a node, 0.6-1.0 $\mathrm{p}$ long, 28-38 $\mu$ in diameter, 2-celled. UItimate rays 2-celled; penultimate cell tapering gradually or abruptly to base of ultimate cell which is a sharp conical mucro. Macros $(N=30)$ (42-) 65-2.5 (-98) $\mu$ long, (17-) 22-.05 (-28) $\mu$ in diameter. Gamotangia solitary or conjoined at 2nd and 3 rd branchlet nodes (single oogonium frequently occurring at lst branchlot node). Oogonia ( $N=22)$ solitary, (325-) 342-2.3 (-364) $\mu$ long, (260-) 272-9.1 (-366) $\mu$ wide; coronula (21-) 28-0.5 (-29) $\mu$ high, (42-) 47-0.9 (-56) $\mu$ wide. Oospores ( $N=20)$ medium brown, (209-) 214-1.0 $(-224) \mu$ long, (189-) 202-1.6 (-210) $\mu$ wide; striae of 5-6 inconspicuous 
Fig. 20. Nitella tenuissima (61-9-9-3). A. Mature branchlet on section of main axis, X 15. B. and C. Range of variation in habit of mature plants, $X 1 / 2$. D. UItimate branchlet rass with characteristic mucros, $\mathrm{X} 275$. 


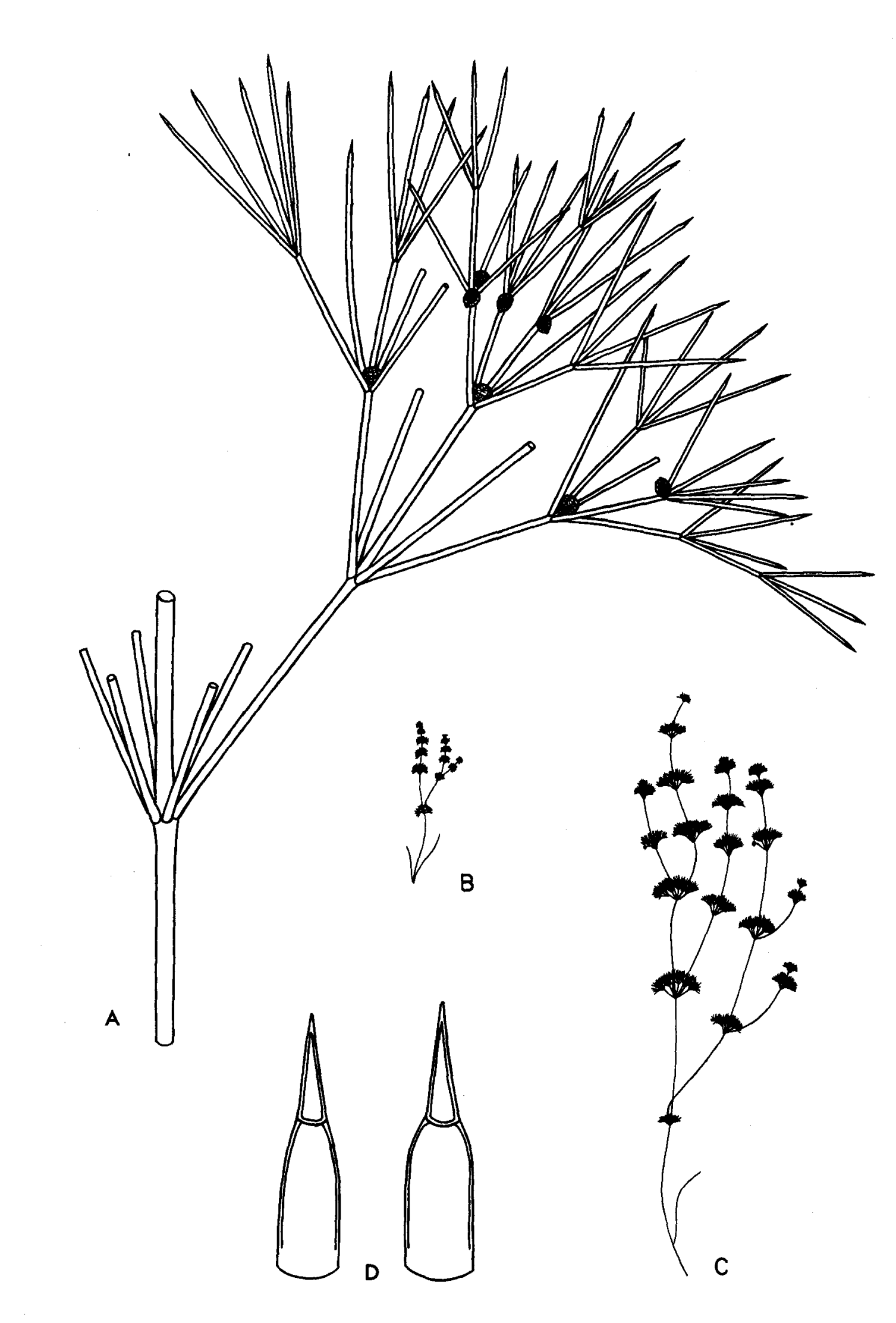


ridges; D.B.A. (41-) 44-0.7 (-50) $\mu$; membrame variable, covered with medium-sized granules (beads?) which frequently coalesce to form a beadlike roticulation. Antheridia $(\mathrm{N}=20)$ solitary, somewhat compressed vertically, (168-) 182-1.1 (-190) $\mu$ wide, 155-175 $\mu$ high, on a short stalk 30-54 $\mu$ long, 29-36 $\mu$ in diameter, 8-scutate.

SPECIMENS EXAMINED: SAN LUIS POTOSI: (61-9-9-3A) Small limestone arroyo flowing W, 31 mi. S Cd. Mante, Mex. Hwy 85, San Luis Potosi, Mexico, D. Tindall, A. Hotchkiss, and R. Goodyear, Sept. 9, 1961.

Nearly identical specimens of $\underline{N}$. tenuissima were observed from Massachusetts and North Carolina (in herb., Unir. Louisville).

TYPE LOCALITY: Burope (vide Wood, 1948).

DISTRIBUTION: According to Wood and Imahori (1959), Nitella tenuissima is a common species in Europe, Africa, Asia, and North Americ2. The know distribution of the species in North America (excluding var. compacta) includes Maine (Taylor, 1921), Massachusetts (Wallman, 1854; Allen, 1880; Braun and Nordstedt, 1882; Dame and Collins, 1888; Tindall and Sawa, 1964), Rhode Island (Halsted, 1879; Allen, 1889), New York (Allen, 1880, 1896; Wood and Mnenscher, 1956), New Jorsey (AlIen, 1880; Britton, 1889), Michigan (Halsted, 1879; Allen 1880; Braun and Nordstedt, 1882; Prescott, 1951), Wisconsin (Prescott, 1oc. cit.), Ohio (Pieters, 1901; Wood, 1947), North Carolina (Wood, 1954; present study), and Florida (Allen, 1880)。

These previous records of the species from North America reveal a more concentrated distribution in the northeast. Although infrequent and widely separated, the occurrence of Nitella tenuissima in southern areas indicates that the species may occur throughout a large part of the continent.

BCOLOGY: The single population of Hitella tenuissima observed in 
the study area occurred in shallow waters of a ponded area of a slowly flowing limestone stream. At the time of collection the water was characterized by the following features: temperature $30 \mathrm{C}$ (air temp. $34 \mathrm{c}), \mathrm{pH} 7.85$, alkalinity $193 \mathrm{mg} / 1$, and free carbon dioxide ca. 5 $\mathrm{mg} / 1$. The species comprised a very minor part of a well-dereloped charophyte community. Chara zeylanica formed a large bed in the deeper waters and Nitella hralina occurred as scattered tufts at intermediate depths. Small isolated tufts of N. acuminata, N. tenuissima, and Chara sejuncta occurred on soft marl in the shallower water near the banks. MORPHOLOGY, CYTOLOGY, AND TAXONOMY: Mature specimens of Nitella tenuissima from the single population observed in the study area were very consistent in respect to all morphological features (description). This was especially evident with regard to branchlet characters, including their delicate but rigid projecting habit, number of furcations, and number of cells making up the ultimate rays.

A chromosome number of 9 was determined for specimens of Nitella tenuissima from the study area. A chromosome number of 9 has also been determined for nearly identical forms of the species from Massachusetts (Tindall and Sawa, 1964) and North Carolina (Hotchkiss, wapublj shed).

Since only a single population of the species was observed, no direct taxonomic problem has arisen. However, several specimens from the study area referable to N. tenuissima var. compacta A. Br. appear to constitute a part of another species which is distinct from N. tenuissima. Further discussion along this line is included below. 


\section{NITELIA GRACILIS SPECIES GROUP}

The specimens included here appear to form a single highly variable species which is separable into two taxa ( $A$ and $B$ ). Certain specimens of Taxon A can doubtlessly be referred to Nitella tenuissima var. compacta A. $\mathrm{Br}$., whereas others show distinct relationships to $\mathrm{N}$. gracilis (Sm.) Ag. Bach of these types was distinguishable at times, but when all of the collections were examined a more or less complete intergradation was observed between them. Taxon $B$ is not directly referable to any previously described form but it is distinctly related to Taxon A.

Inasmuch as the range of variation observed in all of these specimens appears to encompass several forms which have been reported from the study area, a specific name is withheld pending examination of type specimens and specimens collected elsewhere in North America. The present specimens are included within the N. gracilis species group (for North America) which consists of several closely related species, namely $\underline{N}$. tenuissima, N. gracilis, N. transilis T.F.A., N. intermedia T.F.A., and other less known species.

\section{TAXON A}

\section{Figures 21-23}

DESCRIPTION OF SPBC IMENS (including 5 or more mature shoots from each of the following collections: 61-3-30-3, 61-4-4-1, 61-4-5-2A, $61-9-5-3,63-1-23-2,63-1-23-5,63-1-25-6,63-1-25-8,63-1-29-1$, and 63-1-30-2): Plants monoecious, (4-) 7-20 cm high, usually moniliform but sometimes displaying "fox-tail" character, appearing delicate or stout, light green to dark green (grayish before lime is removed), no mucus, frequently heavily incrusted with lime and epiphytes. Main axes (ca. 200-) 285-375 (-ca. 400) $\mu$ in diameter, internodes nearly always 
Fig. 21. TAXON A (Nitella gracilis species group). A. Mature branchlet on section of main axis $(63-1-25-8)$, X 10. B. Mature branchlet (63-1-25-6), X 10. C. Range of variation in shape of mucros $(63-1-25-8), X 275$. D. and F. Same as C (61-3-30-3), X 275. E. Fully developed terminal cell of branchlet; resulting from elongation and expansion of mucro (61-3-30-3), X 275. G.J. Habit sketches of mature plants: G. (62-4-29-3), H. (63-1-302), I. $(62-4-28-3)$, J. $(61-3-30-3)$, all $\times 1 / 2$. 


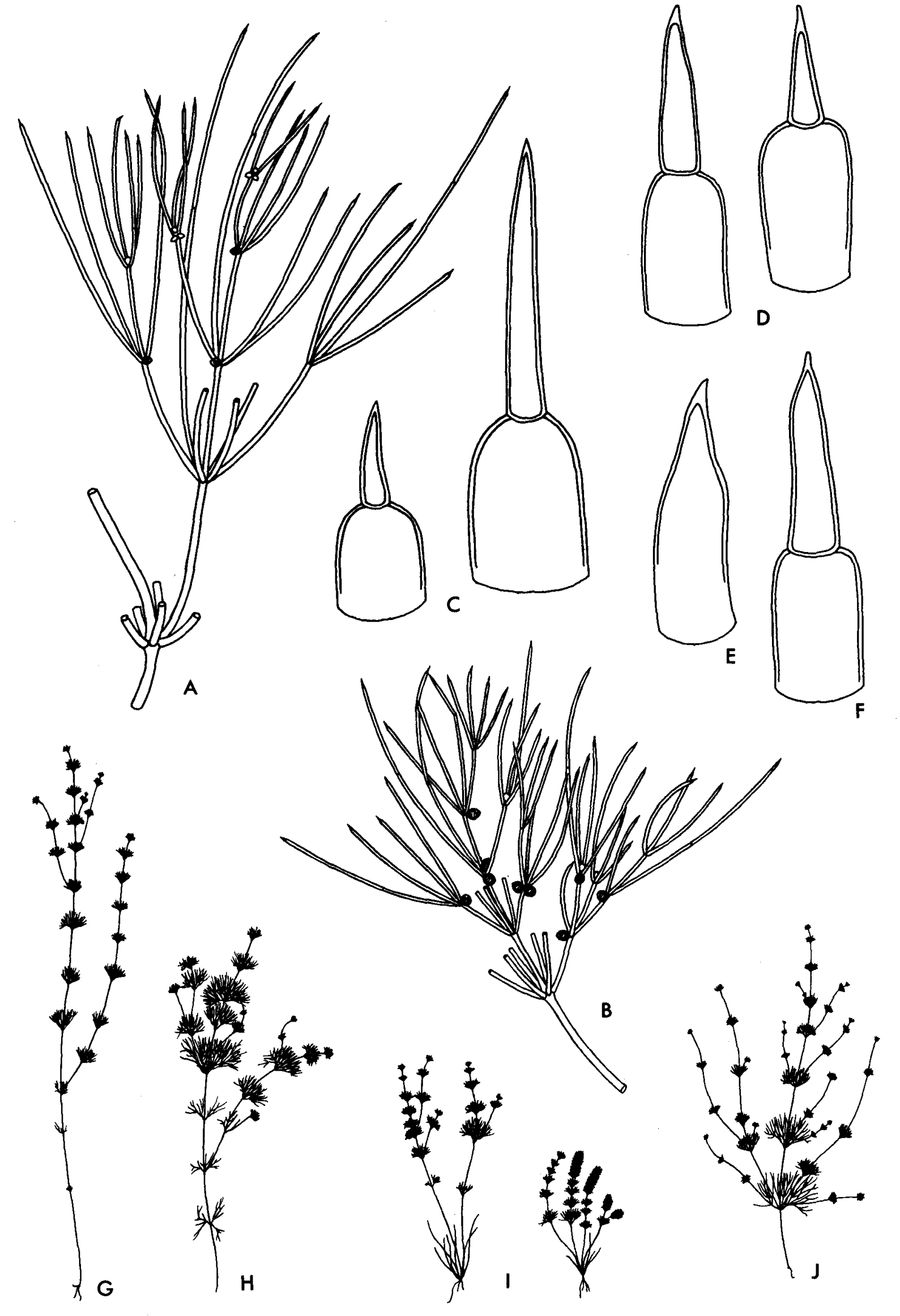


Fig. 22. TAXON A (Nitella gracilis species group, 63-1-23-2). A.-C. Range of variation in habit of mature plants, $X 1 / 2$. D. and $E$. Mature branchlets, X 12.5. F. Young branchlet, X 25 . 


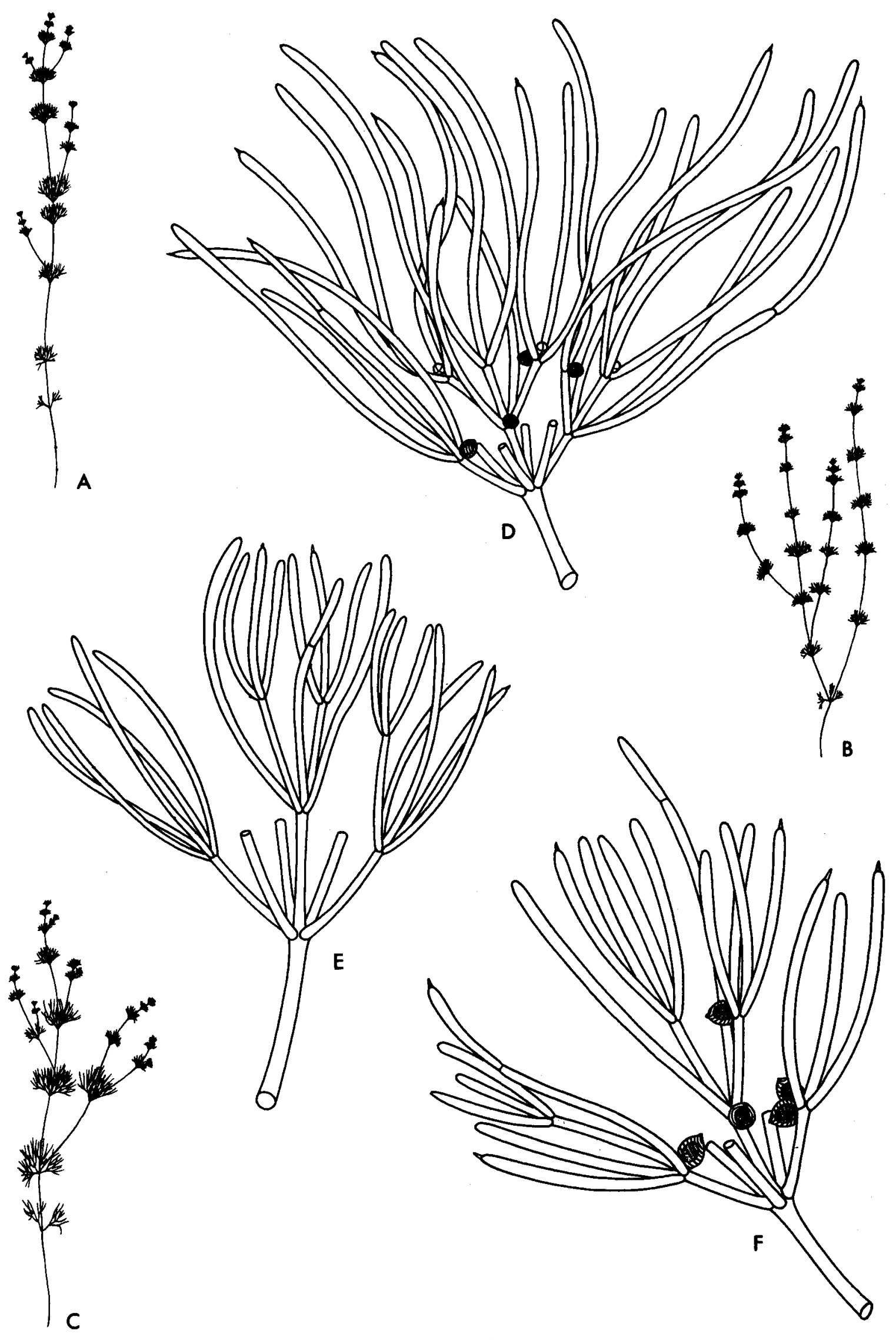


Fig. 23. TAXON A (Nitella gracilis species group, displaying somewhat abnormal vegetative morphology). A. Mature branchlet on section of main axis; displaying fertile shoots in axes of secondary and tertiary rays $(63-1-29-1), X 10 . B_{.}, C_{.}$, and E. Mature branchlets on sections of main axes: B. (61-9-5-3), X 10; C. (61-9-29-1), X 10; E. (63-1-291), X 20. D. Young branchlet (63-9-5-3), X 30, F. and G. Range of variation in terminal rays: F. (61-9-5-3), X 133; G. (63-1-29-1), X 133. 


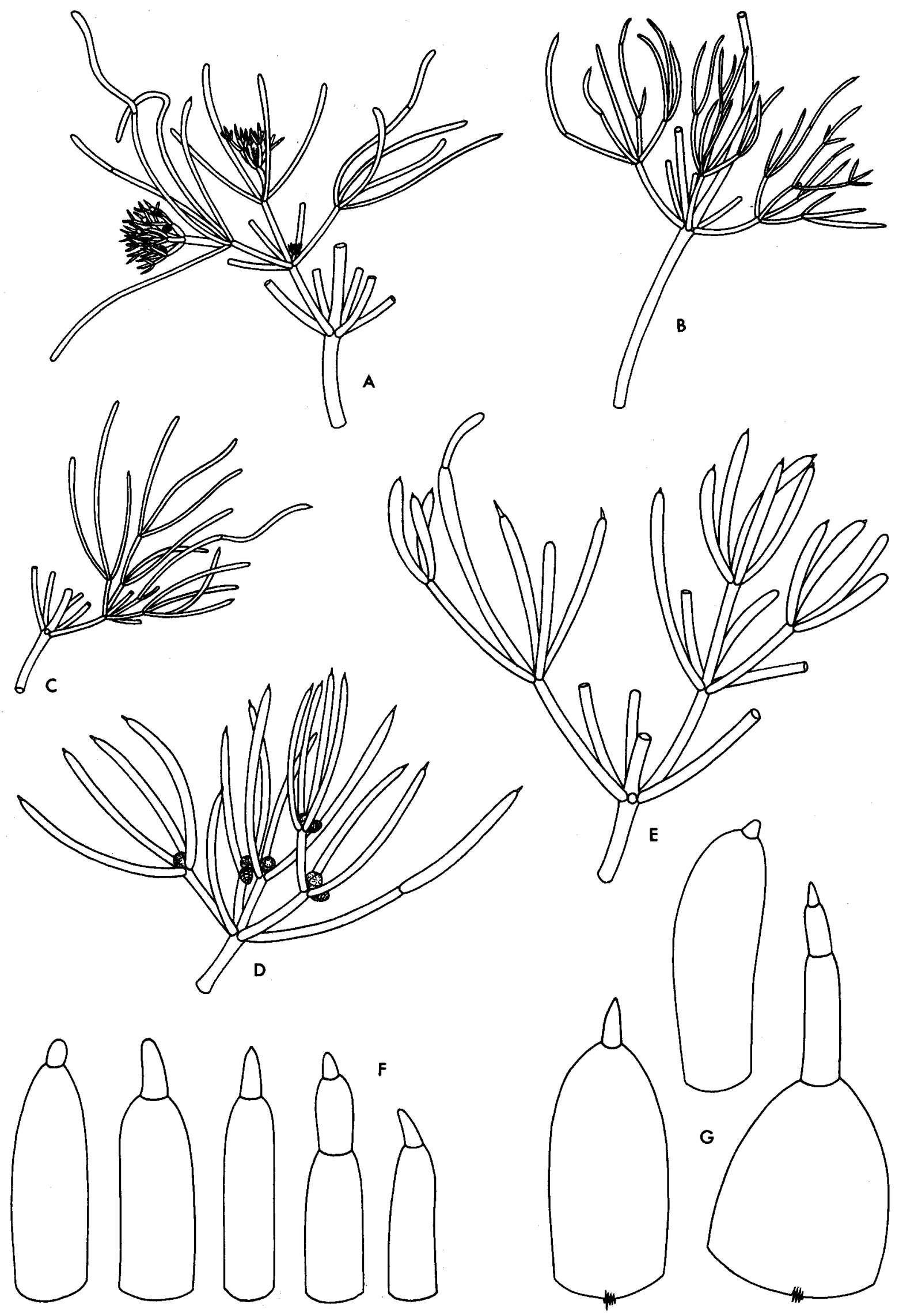


longer than branchlets. Iower sterile branchlets frequently 1-2 furcate with markedly swollen rays. Mature fertile branchlets consistently 6 in a whorl (very rarely 5 or 7 ), usually less than $I \mathrm{~cm}$ long, always up to 3-furcate and frequently partially 4-furcate (very rarely 5-furcate); primary rays straight, (0.6-) 1.0-3.2 (-3.7) mm Iong, (63-) 95-195 (-210) $\mu$ in diameter; secondary rays straight, (5-) 6-7 at a node (including percurrent ray), (0.4-) 0.9-2.2(-2.6) long, (43-) 60-125 (-180) $\mu$ in diameter, sometimes simple and (2-) 3(4-)-celled; tertiary rays straight when forked or variously curved when simple, (3-) 4-5 (-6 or 7 when percurrent ray is present) at a node, $(0.5-) 0.8-3.4(-6.5) \mathrm{mm}$ Iong (Ionger ones are simple and 2-3-celled), (36-) 54-125 (-180 at distal end of penultimate cell) $\boldsymbol{\mu}$ in diameter; quaternary rays (when present) straight or curved, (2-) 3-5 (-6) at a node, (0.3-) 0.7-2.7 (-6.5) mm long (longer ones are simple and 2-3-celled), (35-) 45-90 (-150 at distal end of penultimate cell) $\mu$ in diameter; quinary rays frequently lacking, (2-) 3-4 (-5) at a node, 0.8-3.4 cm long, 34-105 $\boldsymbol{\mu}$ in diameter, 2-3-celled. OItimate rays $2-3(-4)$-celled; penultimate cell narrow or swollen, usually tapering abruptly to base of ultimate cell which is a conical mucro. Mucros, normal ones, are deciduous or persistent, sharp or blunt, (35-) 65-115 (-158) $\mu$ long, 20-40 $\mu$ in diameter; abnormal ones frequent, forming a long terminal cell, equal to penultimate cell in diameter, acute or acuminate. Gametangia solitary or conjoined. Dogonia usually on a short stalk, frequently solitary at lst branchlet node, 102(-3) at 2nd node, 1 at $3 \mathrm{rd}$ node, and rarely 1 at 4 th node, 315-455 $\mu$ Iong, 250-320 $\mu$ wide; coronula persistent, 29-47 $\mu$ high, 43-61 $\mu$ wide. Dospores medium brown to dark chestnut brown, 185-250 $\mu$ long, 170-225 $\mu$ wide; striae of 7-8 (-9) low but thick ridges; D.E.A. 23-43 $\mu$; membrane variable, ranging from distinctly coarsely granulate to reticulate 
(appearing beaded, very much like that of $\underline{N}$. tenuissima). Antheridia solitary at 2nd and 3rd , rarely 4 th) branchlet nodes, frequently compressed rertically, 144-191 $\mu$ wide, 8-scutate.

SPEC IMENS EXAMINED: OKLAHOMA: (60-8-14-2C) Honey Creek, in current ca. 0.5 mi. above Turner's Falls, Murray Co., Oklahoma, D. Tindall, W. Minckley, and J. Craddock, Aug. 14, 1960. (62-4-28-3) Buffalo Spring, swift stream, Platt National Park, Murray Co., Oklahoma, D. Tindall, A. Hotchkiss, and W. Minckley, April 28, 1962. (62-4-28-6) Antelope Spring (in slowly flowing pool), Platt National Park, Murray Co., Oklahoma, D. Tindall, A. Hotchkiss, and W. Minckley, April 28, 1962. (62-4-29-3) Stream, 8 mi. W Hugo, U.S. Hwy 70, Choctaw Co., Oklahoma, D. Tindall, A. Hotchkiss, and W. Minckley, April 29, 1962.

TEXAS: (61-3-30-3) North San Gabriel River, 28 mi. N Austin, U.S. Hwy 81, Williamson Co., Texas, D. Tindall and W. Minckley, March 30, 1961. (61-4-1-2) Onion Creek, SSE Austin, near Bergstrom Air Base, Travies Co., Texas, D. Tindall and W. Minckley, April 1, 1961. (61-4-4-1) and (61-9-15-1) Rio Frio, below Upper Camp Area, Garner State Park, Uvalde Co., Texas, D. Tindall and W. Minckley, April 4, 196I; D. Tindall, A. Hotchkiss, and R. Goodyear.

COAHUIIA: (6I-4-4-4C) Arroyo Concordia, first stream S Piedras Negras, Mex. Hwy 57, Coahuila, Mexico, D. Tindall and W. Minckley, April 4, 1961. (61-9-14-1 specimen lost) Rio de Nava (swift), 5 mi. SW Nava, water from large spring near Morelos, flows to irrigation ditches, off Mex. Hwy 57, Coahuila, Mexico, D. Tindall, A. Hotchkiss, and R. Goodyear, Sept. 14, 1961. (61-4-4-6B) Rio Salado de los Nadadores, 2 mi. S Hermanas, off Mex. Hwy 57, Coahuila, Mexico, D. Tindall and W. Minckley, April 4, 1961. (61-4-5-2) Río Salado de los Nadadores at Celemania, $0.5 \mathrm{mi}$. below entrance to Sacramento Basin, off State Hwy 30, Coahuila, Mexico, D. Tindall and W. Minckley, April 5, 1961. 
NUEVO LEON: (63-1-30-2) Rio Cabezones (swift), 16 mi. NW Linares, Mex Hwy 85, Nuevo Leon, Mexico, D. Tindall and A. Hotchkiss, Jan. 30, 1963. (63-1-30-4) Rio Ramos, 45 mi. NW Linares, Mex. Hwy 85, Nuevo Leon, Mexico, D. Tindall and A. Hotchkiss, Jan. 30, 1963.

TAMAULIPAS: (63-1-23-2) Irrigation canal (swift), just N Rio Purificacion, at Padilla, Mex. Hwy 101, Tamaulipas, Mexico, D. Tindall and A. Hotchkiss, Jan. 23, 1963. (63-1-23-5) Low-water pool of Rio Purificacion (separated from River), below bridge at Padilla, Mex. Hwy 101, Tamaulipas, Mexico, D. Tindall and A. Hotchkiss, Jan. 23, 1963. (61-9-5-3) and (63-1-29-6A \& B) Rio Guayalejo, $37 \mathrm{mi}$. S Cd. Victoria, off Mex. Hwy 85, Tamaulipas, Mexico, D. Tindall, A. Hotchkiss, and R. Goodyear, Sept. 5, 1961; D. TindalI and A. Hotchkiss, Jan. 29, 1963. (63-1-29-1) In flowing water of the Tio Sabinas, $3 \mathrm{ml}$. W on logging road from Elmcino, $30 \mathrm{mi}$. N Cd. Mante, Mex Hwy 85, Tamaulipas, Mexico, D. Tindall and A. Hotchkiss, Jan. 29, 1963. (63-1-25-8) Arroyo, 16 mi. S Mante, Mex. Hwy 85, Tamaulipas, Mexico, D. Tindall and A. Hotchkiss, Jan. 25, 1963.

SAN LUIS POTOSI: (63-1-25-6) Arroyo, $17 \mathrm{mi}$. N Cd. Valles, Mex. Hwy 85, San Luis Potosi, Mexico, D. Tindall and A. Hotchkiss, Jan. 25, 1963.

DISTRIBUTION: Records of Nitella tennissima var. compacta and N. gracilis from or near the study area are presently included in the discussion of the distribution of Taxon A. Braun (Bram and Nordstedt, 1882) described N. tenuissima var. compacta from specimens collected in New Mexico (type locality, vide Wood, 1948), Texas, and Mexico (?) ("Monterey in Nord-Mexico [California] ..."). Braun originally recorded the species from North Mexico but Nordstedt later inserted California without clarification, thus causing considerable confusion as to the 
actual locality. Braun (Braun and Nordstedt, loc. cit.) described var. compacta $f$. domingensis from the Dominican Republic ("St. Dimingo Haiti ..."). H. and J. Groves (1911) reported specimens representing var. compacta (as N. tenuissima) from Cuba. Daily (in Hevly, 1961) identified var. compacta from Cochise County, Arizona. Specimens reported as N. gracilis probably referable to Taxon A include those from New Mexico (Holsted, 1879), Texas (Braun and Nordstedt, 1882), and Louisiana (as var. divaricata Mig., Allen, 1896). Nitella gracilis reported from Venezuela, Brazil (Braun and Nordstedt, 1882), and Uruguay (Allen and Herter, 1934) may also be referable to Taxon A.

The known distribution of Taxon $A, \underline{N}$. tenuissima var. compacta, and N. gracilis in the study area is included in Figure 24. These forms show a distinctly southern distribution in North America but further study may reveal a more precise relationship to tropical and subtropical regions.

BCOLOGY: Physicochemical features of the habitats.--Taxon A was observed only in streams, most of which were in limestone regions and many were spring fed (Table 13). The habitats varied from still pools to swiftly flowing waters. These extremes appeared to have a direct effect on the general morphology of the plants. Plants from the swiftest waters were quite distinctly Nitella tenuissima var. compacta types, whereas those from very still waters represented $\underline{N}$. gracilis types. Intermediate flow conditions supported a variety of intermediate and intergrading types. The restriction of the two distinguishable types to rather limited environmental conditions and the occurrence of a complete intergrading series in intermediate environmental conditions forms the basis for the inclusion of all the specimens within a single taxon. 


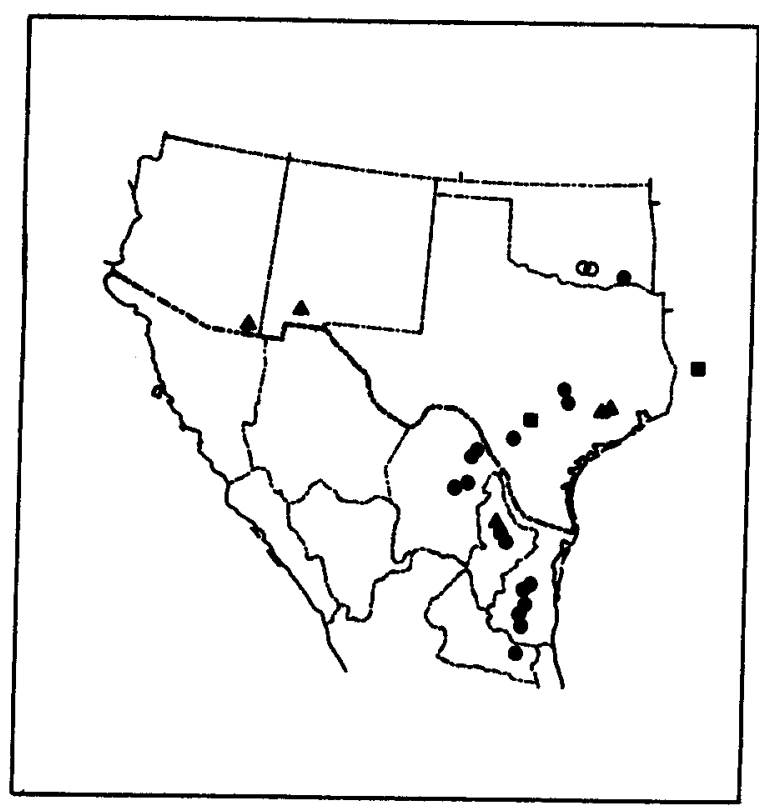

Fig. 24. Distribution of TAXON A and TAXON B of the Nitella gracilis species group in the study area; localities of TAXON A examined during the present study, $O$ localities of TAXON $B$ examined during the present study, $\triangle$ localIties of $\underline{\text {. tenuissima }}$ var. compacta reported in the Iiterature, 1 localities of N. gracilis reported in the literature. 
Table 13. Phystoochemical features of the habitats supporting Taxon A (Nitella gracilis species group).

\begin{tabular}{|c|c|c|c|c|c|c|c|c|c|c|c|}
\hline Specimens & Locality & Habitat & Subs trate & Depth & $\begin{array}{l}\text { Tur- } \\
\text { bidity }\end{array}$ & Light & $\begin{array}{l}\text { Tompe } \\
\text { air }\end{array}$ & $\begin{array}{l}\text { rature } \\
\text { water }\end{array}$ & $\mathrm{pH}$ & Alk. & $\mathrm{CO}_{2}$ \\
\hline $60-8-14-2 c$ & Oklahoma & swift s tream & $\operatorname{marl}$ & $0.1-0.3$ & 0 & $\begin{array}{l}\text { open \& } \\
\text { shaded }\end{array}$ & 25.0 & 20.0 & 8.2 & 253 & 2.5 \\
\hline $62-4-28-3$ & Oklahoma & $\begin{array}{l}\text { swift spring } \\
\text { s tream }\end{array}$ & sand & $0.07-0.3$ & 0 & shadod & 22.0 & 17.5 & 7.2 & 326 & 39.0 \\
\hline $62-4-28-6$ & Oklahome & $\begin{array}{l}\text { spring stream } \\
\text { pool }\end{array}$ & $\begin{array}{l}\text { mar1- } \\
\text { gravel }\end{array}$ & $0.05-0.2$ & 0 & $\begin{array}{l}\text { open \& } \\
\text { shaded }\end{array}$ & 25.0 & 17.5 & 7.4 & 333 & 6.0 \\
\hline $62-4-29-3$ & Oklahana & $\begin{array}{l}\text { slow flowing } \\
\text { s trean }\end{array}$ & silt-marl & $0.30-0.5$ & 0 & open & 26.0 & 19.0 & 7.9 & 242 & 5.0 \\
\hline $61-3-30-3$ & Texas & $\begin{array}{l}\text { still \& slow- } \\
\text { flowing s tream }\end{array}$ & marl-silt & $0.05-0.2$ & 0 & $\begin{array}{l}\text { opon \& } \\
\text { shaded }\end{array}$ & 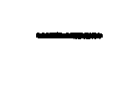 & 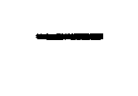 & - & - & \\
\hline $61-4-1-2$ & Texas & s tream pool & marl-silt & $0.05-0.1$ & 0 & open & & - & - & - & \\
\hline $61-4-4-1$ & Texas & $\begin{array}{l}\text { s low-flowing } \\
\text { s tream }\end{array}$ & silt-marl & $0.10-0.2$ & 0 & $\begin{array}{l}\text { open \& } \\
\text { shaded }\end{array}$ & & & - & - & \\
\hline $61-9-15-1$ & Tөxas & $\begin{array}{l}\text { slow-flowing } \\
\text { s tream }\end{array}$ & silt-marl & $0.05-0.2$ & $Q$ & $\begin{array}{l}\text { open } \\
\text { shaded }\end{array}$ & - & 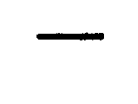 & 一 & - & \\
\hline $6 I-4-4-4 C$ & Coahuila & stream pool & $\operatorname{mar} 1$ & $0.10-0.4$ & 0 & open & & 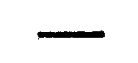 & 一 & - & \\
\hline $61-9-14-1$ & Coahuila & swift 8 tream & $\operatorname{mar} 1$ & $0.02=0.03$ & 0 & shaded & & . & - & - & \\
\hline $61-4-4-6 B$ & Coahuila & $\begin{array}{l}\text { 8low-flowing } \\
\text { s tream }\end{array}$ & $\operatorname{marl}-8 i 1 t$ & 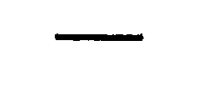 & 0 & open & - & - & - & - & \\
\hline $61-4-5-2$ & Coahuila & swift stream & gravel & $0.05-0.1$ & (0) & open & 23.3 & 24.0 & 7.6 & 214 & 10.0 \\
\hline $63-1-30-2$ & Nuevo Leon & swift s tream & sand & $0.03-0.05$ & 0 & $\begin{array}{l}\text { open \& } \\
\text { shaded }\end{array}$ & 20.0 & 16.0 & 7.75 & 155 & 6.5 \\
\hline $62-1-30-4$ & Nuevo Leon & swift s tream & sand & $0.05-0.11$ & 0 & $\begin{array}{l}\text { open \& } \\
\text { shaded }\end{array}$ & 24.0 & 18.0 & 7.5 & 180 & 10.5 \\
\hline $63-1-23-2$ & Tamaulipas & swift canal & sand & $0.20-0.35$ & 0 & open & 25.0 & 20.0 & 8.0 & 207 & 3.5 \\
\hline $63-1-23-5$ & Tamaulipas & s tream pool & sand-silt & $0.20-0.3$ & 0 & open & 22.0 & 20.0 & 8.0 & 153 & 2.0 \\
\hline
\end{tabular}


Table 13. continued

\begin{tabular}{|c|c|c|c|c|c|c|c|c|c|c|c|}
\hline $61-9-5-3$ & Tameulipas & swift stream & sand-silt & $0.05-0.2$ & 0 & open & 30.5 & 27.0 & 7.85 & 129 & 2.0 \\
\hline $63-1-29-6$ & Tamaulipas & swift stream & sand-silt & $0.05-0.1$ & 0 & open & 23.0 & 20.0 & 7.4 & 118 & 9.0 \\
\hline $63-1-29-1$ & Tamaulipas & swift stream & sand-marl & $0.05-0.1$ & 0 & shaded & 30.0 & 21.0 & 7.8 & 185 & 5.0 \\
\hline $63-1-25-6$ & $\begin{array}{l}\text { San Luis } \\
\text { Potosi }\end{array}$ & stream pool & $\operatorname{mar} 1-8 i l t$ & $0.20-0.4$ & + & open & 28.0 & 21.0 & 7.2 & 315 & 37.5 \\
\hline
\end{tabular}

Table 14. Uajor components of plant commities containing Taxon A (Nitella gracilis species group).

\begin{tabular}{|c|c|}
\hline Taxon A & Other plants \\
\hline $60-8-14-20$ (rare tufts) & $\frac{\text { Nitella gracilis }}{\text { (abundant in pools). Group Taxon B (abundant tufts). Chara contraria }}$ \\
\hline $62-4-28-3$ (abundant tufts) & $\begin{array}{l}\text { Chara vulgaris (scattered tuf ts), Nitella mirabilis (rare tufts). } \\
\text { Batrachospermun sp. (abundant), Nasturtium officinale (abundant). }\end{array}$ \\
\hline $62-4-28-6$ (isolated tufts) & Nitella gracilis $\mathrm{sp}$. group Taxon B (isolated tufts). \\
\hline $62-4-29-3$ (abundant tuf ta) & $\begin{array}{l}\text { Tolypella } 8 p \cdot \text { (abundant), Nitella mirabilis (rare), Chara contraria } \\
\text { (abundant). }\end{array}$ \\
\hline $61-3-30-3$ (rare tuf ts) & Chara contraria (rare). \\
\hline $61-4-1-2$ (rare tufts) & Chara contraria (abundant), Nitella missouriensis (rare). \\
\hline $61-4-4-1$ (1arge beds) & Chara contraria (abundant), Nitella missouriensis (rare). \\
\hline $61-9-15-1$ (rare) & None \\
\hline $61-4-4-4 c$ (rare tuf ts) & Chara contraria (largo beds), Najas guadalupens is (abundant). \\
\hline $61-9-14-1$ (rare) & None \\
\hline $61-4-4-6 B(\operatorname{rar} \theta)$ & Chare contraria (abundant). Na jas guadalupensis (abundant). \\
\hline
\end{tabular}


Table 14. continued

\begin{tabular}{|c|c|}
\hline $61-4-5-2$ (rare tuf ts) & 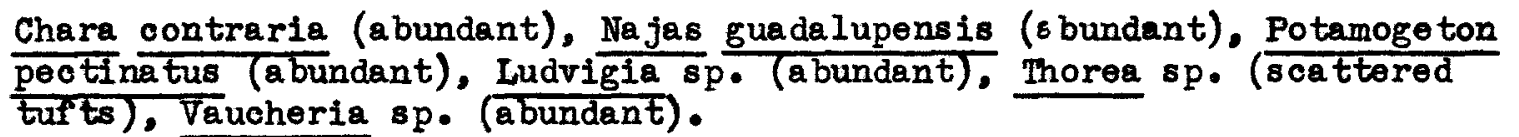 \\
\hline $63-1-30-2$ (abundant tufts) & Chara contraria (abundant) \\
\hline $63-1-30-4$ (abundant tufts) & Chara contraria (abundant), Batrachospermum sp. (rare) \\
\hline 63-1-23-2 (abundant tufts) & Chara contraria (scattered tufts) \\
\hline $63-1-23-5$ (scattered tufts) & Nitella hyalina (scattered tufts) \\
\hline 63-1-29-6 (abundant tufts) & $\frac{\text { Chara }}{\text { (abundant) }} \frac{\text { contraria }}{\text { (abundant), C. zeylanica (abundant), Nitella hyalina }}$ \\
\hline $63-1-29-1$ (scottered tufts) & Chara contraria (abundant), Batrachospermum sp. (abundant), Thorea sp. \\
\hline $63-1-25-8$ (abundant tufts) & $\frac{\text { Chara }}{\text { (abundant) }}$ contraria (abundant), Nitella hyalina (abundant), N. oligospira \\
\hline
\end{tabular}


The types of substrate supporting the species appeared to be directly related to flow conditions (Table 13). The species was firmly rooted in sand or coarse marl in swiftly flowing waters, whereas it occupied areas of fine sand, marl, and silt in still or slowly flowing waters. The species was not observed at depts exceeding $0.45 \mathrm{~m}$, and quite frequently occurred in only $3-6 \mathrm{~cm}$ of water. All but a single locality supporting the species contained very clear water; the one exception was only moderately turbid. The consistent occurrence of the species in cool waters and its more common occurrence during winter and spring months indicate a limited upper temperature level. The apparent lack of the species in more northern areas suggest that it might also be limited by lower temperatures. Thus, the species appear to display a relatively narrow tolerance range to temperature. Estimates of $\mathrm{pH}$, alkalinity, and free carbon dioxide of the waters supporting the species are included in Table 13. Of these factors, marked variation among the localities was limited to free carbon dioxide content but none of the waters was found to be void of the gas. This finding was somewhat unexpected since many of the specimens were characterized by extensive lime incrustation. These observations indicate that the species might occupy inconspicuous microenvironments characterized by higher $\mathrm{pH}$ and lower or negligible amounts of free carbon dioxide. Such conditions would most frequently occur in still waters supporting extensive vegetation. This is in agreement with observations made during this study; the heaviest lime incrustation occurred on plants from still or slightly agitated waters, and only moderate incrustation was observed on those from most of the extremely swift waters.

Plant communities.--Taxon A occurred as isolated tufts or formed 
small beds in association with other charophyte species (Table 14 ). Chara contraria was nearly always associated with the Nitella; however, the relationship of the two speceis varied among the various habitats. In some instances both species were observed side-by-side in swiftly flowing waters. On other occasions the Chara was observed in quiet pools and the Nitella was limited to the current areas. The reverse of that arrangement also was frequently observed. Species of Batrachospermum and Therea were commonly associated with Taxon A in some of the swiftest waters. Specimens of collection 63-1-29-1 were nearly covered with the chantransia of Batrachospermum spp. and other chantransia-like plants (Audouinella?). Najas guadalupensis was the only higher plant commonly associated with the Nitella.

Taxon A and Taxon B were observed together in only two localities, both of which occurred at the northern limits of the known geographical range of Taxon A (Murray Co., south-central Oklahoma). In each instance, the two forms were randomly distributed in separate tufts.

MORPHOLOGY AND CYTOLOGY: A more or less complete analysis of the vegetative morphology of specimens from several collections of Taxon A is included in Table $15 \mathrm{~A}$ and Figures 21-23. Variations among the plants are limited to relative sizes and numbers of branchlet rays, relative frequency of branchlet furcations, and length and persistency of mucros. Analysis of only two or three of the specimens could have led me to conclude that the plants represent two independent taxa, one being characterized by less furcate branchlets, stouter branchlet rays, and deciduous mucros; the other being characterized by greater branchlet furcation, narrower rays, and persistent mucros. These two forms mark the extremes in the Taxon A complex, representing Nitella tenuissima var. compacta at one extreme and $N$. gracilis at the other. It is quite apparent 
Table 15A. A comparison of various vegetative features of specimens of Taxon A (Nitella gracilis apecies group).

\begin{tabular}{|c|c|c|c|c|c|c|c|c|c|}
\hline SPECIMBHS & $\begin{array}{l}\text { MaIf AXI } \\
\text { height } \\
(\mathrm{cm})\end{array}$ & $\begin{array}{l}\text { ES } \\
\text { diam. }\end{array}$ & $\begin{array}{l}\text { Prim } \\
\text { no. }\end{array}$ & $\begin{array}{l}\text { F E } \\
\text { ary ray } \\
\text { length } \\
\text { (min) }\end{array}$ & $\begin{array}{l}\text { R T I } \\
\text { Ys } \\
\text { diam. }\end{array}$ & $\begin{array}{c}\text { L E B R A N C H } \\
\text { Secondary rays } \\
\text { no. length diam. } \\
\text { (mm) }\end{array}$ & $\begin{array}{l}\text { I B T S } \\
\text { Tertiary rays } \\
\text { no. length diam. } \\
\text { (am) }\end{array}$ & $\begin{array}{c}\text { Quaternary rays } \\
\text { no. length diam. } \\
\text { (min) }\end{array}$ & $\begin{array}{l}\text { Quinary rays } \\
\text { no. lengtb diam. } \\
\text { (am) }\end{array}$ \\
\hline $63-1-25-8$ & -20 & -285 & 6 & $\begin{array}{l}1.3- \\
3.2\end{array}$ & $\begin{array}{l}63- \\
130\end{array}$ & $\begin{array}{lll}(5-) & 0.7- & 43- \\
6-7 & 2.4 & 90 \\
\text { frequently sim- } & \text { ple \& } 3 \text {-celled }\end{array}$ & $\begin{array}{lll}3-4 & 0.9- & 36- \\
(-5) & 3.4 & 66 \\
\text { frequently sim- } \\
\text { ple \& } 3 \text {-celled }\end{array}$ & 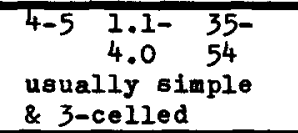 & $\begin{array}{lcc}2 & 1.0- & 34- \\
1.7 & 39 \\
\text { simple \& } & 2-3- \\
\text { celled } & \end{array}$ \\
\hline $63-1-25-6$ & -16 & -315 & 6 & $\begin{array}{l}1.7- \\
3.7\end{array}$ & $\begin{array}{l}128- \\
191\end{array}$ & $\begin{array}{lll}6-7 & 0.9- & 79- \\
& 2.6 & 117\end{array}$ & $\begin{array}{lll}4-5 & 1.2- & 54- \\
(-6) & 3.0 & 83 \\
\text { frequently sim- } & \\
\text { ple \& } & 2-3-c e l l e d\end{array}$ & $\begin{array}{lll}(2-) & 0.4- & 47- \\
3-4 & 3.7 & 72 \\
\text { frequently sim- } & \\
\text { ple \& } 2-3-c e l l e d\end{array}$ & $\begin{array}{ccc}3-4 & 0.9- & 48- \\
2.5 & 61 \\
& \\
\text { simple or rarely } \\
\text { forked again }\end{array}$ \\
\hline $61-4-4-1$ & -10 & -300 & 6 & $\begin{array}{l}1.0- \\
1.5\end{array}$ & $\begin{array}{l}110- \\
130\end{array}$ & $\begin{array}{ll}0.6- & 50- \\
1.3 & 75\end{array}$ & $\begin{array}{lll}(4-) & 0.7- & 45- \\
5-6 & 3.2 & 60 \\
\text { frequently sim- } \\
\text { ple \& } 2-3-c e l l e d\end{array}$ & $\begin{array}{ccc}3-4 & 1.2- & 37- \\
2.7 & 52 \\
& \\
\text { usually simpl- } \\
\& 2-3-c e l l o d\end{array}$ & 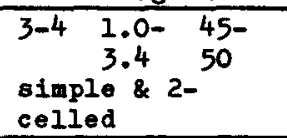 \\
\hline $61-3-30-3$ & -12.5 & -300 & $\overline{6}$ & $\begin{array}{l}1.1- \\
2.8\end{array}$ & $\begin{array}{l}85- \\
95\end{array}$ & $\begin{array}{lll}6-7 & 0.9- & 50- \\
& 1.9 & 65\end{array}$ & $\begin{array}{lll}5-6 & 0.9- & 45- \\
(-7) & 3.7 & 50 \\
\text { frequently sim- } & \\
\text { ple \& } & 2-3-c e l l e d\end{array}$ & $\begin{array}{ccc}4-5 & 1.3- & 35- \\
(-6) & 4.5 & 45 \\
\text { usually } & \text { simple } \\
\text { \& } 2-3-c e l l e d\end{array}$ & $\begin{array}{llr}4-5 & 2.0- & 35- \\
3.0 & 40 \\
& \\
\text { simple \& } 2-3- \\
\text { colled }\end{array}$ \\
\hline $63-1-30-2$ & -15 & -330 & 6 & $\begin{array}{l}1.5- \\
2.5\end{array}$ & $\begin{array}{l}105- \\
145\end{array}$ & $\begin{array}{lll}6-7 & 0.9- & 80- \\
& 2.2 & 105 \\
& \\
\text { frequently } & \text { s1m- } \\
\text { ple \& } & 2-c e l l e d\end{array}$ & $\begin{array}{lll}(3-) & 1.2- & 50- \\
4-5 & 2.2 & 95 \\
\text { frequently sim- } \\
\text { ple \& } 2-3-\text { celled }\end{array}$ & $\begin{array}{llr}3-4 & 0.8- & 45- \\
& 2.5 & 85 \\
\text { simple \& } 2-3- \\
\text { colled }\end{array}$ & NONE \\
\hline $63-1-23-5$ & -19.5 & - & 6 & - & - & $6-7$ & $\begin{array}{l}4-5-- \\
(-6) \\
\text { frequently sim- } \\
\text { ple \& 2-3-celled }\end{array}$ & $\begin{array}{l}(2-)- \\
3-4 \\
\text { usually simple } \\
\text { \& 2-3-celled }\end{array}$ & $\begin{array}{l}3-4-- \\
(-5) \\
\text { simple \& 2- } \\
\text { celled }\end{array}$ \\
\hline $63-1-23-2$ & -20 & -375 & 6 & $\begin{array}{l}1.1- \\
2.6\end{array}$ & $\begin{array}{l}120- \\
210\end{array}$ & $\begin{array}{ccc}6-7 & 0.4- & 75- \\
2.2 & 135 \\
& 2.2 \\
\text { sometimes sim- } \\
\text { ple \& } & 2-3-\text {-celled }\end{array}$ & $\begin{array}{ccc}4-5 & 0.8- & 75- \\
& 2.8 & 180^{*} \\
& 2.8 \\
\text { frequently sim- } \\
\text { ple \& } 2-3-c e l l e d\end{array}$ & $\begin{array}{c}3-4 \quad 0.6-95- \\
2.0 \text { 150* } \\
\text { usually simple } \\
\& 2-3-c e l l e d\end{array}$ & $\begin{array}{l}3-4 \text { 0.8- } 90- \\
1.1 \text { 105* } \\
\text { simple \& 2- } \\
\text { celled }\end{array}$ \\
\hline $61-4-5-2 A$ & -8.0 & -330 & 6 & $\begin{array}{l}0.6- \\
1.1\end{array}$ & $\begin{array}{l}180- \\
210\end{array}$ & $\begin{array}{lll}6-7 & 0.5- & 95- \\
& 1.0 & 125\end{array}$ & $\begin{array}{l}4-5 \text { 0.5- } 90- \\
(-6) 2.3 \text { 150. } \\
\text { usually simple } \\
\& 2-c e l l e d\end{array}$ & 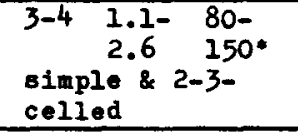 & NONE \\
\hline $63-1-29-1$ & -8.0 & -310 & $(5-)$ & $\begin{array}{l}0.7- \\
3.2\end{array}$ & $\begin{array}{l}120- \\
200\end{array}$ & $\begin{array}{rll}4-) & 0.4- & 95- \\
5-6 & 2.6 & 180\end{array}$ & $\begin{array}{l}3-4 \text { 0.6- } 90- \\
(-5) \quad 3.0 \text { 150* } \\
\text { usually simple } \\
\& 2-3-c e l l e d\end{array}$ & $\begin{array}{lll}2-4 & 0.6- & 90- \\
& 2.8 & 135^{\circ} \\
\text { simple \& } 2- \\
\text { celled }\end{array}$ & NONE \\
\hline $61-9-5-3$ & -7.0 & -340 & 6 & $\begin{array}{l}0.8- \\
1.4\end{array}$ & $\begin{array}{l}140- \\
195\end{array}$ & $\begin{array}{ccc}5-6 & 0.6 & 96- \\
& 2.1 & 154 \\
& \\
\text { sometimes } & \text { sim- } \\
\text { ple \& } 2-3-\text {-celled }\end{array}$ & $\begin{array}{lll}(2-) & 0.8- & 70- \\
3-4 & 1.1 & 105 \\
\text { usually simple } \\
\text { \& } 2-3-\text {-celled }\end{array}$ & 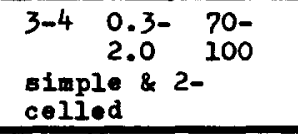 & NONE \\
\hline
\end{tabular}

- swollen terminal rays 
however, that a complete intergrading series is formed among the specimens included in Table 15A. Certain specimens excluded from the table are even more distinctly intermediate than those included. As mentioned above, these two general morphological types appear to result primarily from differences in environmental conditions, especially velocity of flow. It appears that the swifter waters were conducive to production of the shorter, less forked, and stouter plants. Markedly swollen ultimate branchlet rays and deciduous mucros also characterized this form. The disengagement of the mucros from the penultimate cells appeared to result from rapid expansion of the latter cells as opposed to a very determinant growth character of the former ones. The swift waters probably aided in the complete separation of the two cells. On the other hand, the rather tall and delicate plants from very still waters displayed persistent macros but frequently produced long well-developed ultimate cells which were not at all characteristic of mucros (Fig. 21E). Although the mucro is normally a very determinant structure, the elongate ultimate cells resulted from elongation and expansion of mucros. The actual significance of this feature cannot be determined at this time but it may prove indicative of certain phylogenetic relationships.

A comparison of various features of the gametangia and oospores of Taxon A is shown in Table 15B. Marked variations were observed only in length and width of oogonia. The oospores were very consistent in respect to Iength and width, ranging from 185-250 $\mu$ long (mean range, 208-242) and 170-225 $\mu$ wide (mean range 191-213). They were also consistent with regard to number and prominence of ridges, and D.E.A. On the other hand, the oospores from single specimens and from separate collections displayed considerable variation in membrane decoration. Some plants had oospores which were consistently coarsely granulate 
Tablo 15B. A comparison of mucros, gametangia, and oospores of specimens of Taxon A (M1tella gracilis species group).

\begin{tabular}{|c|c|c|c|c|c|c|c|c|c|c|c|c|}
\hline & & $\begin{array}{l}\text { M } J C R \\
\text { length }\end{array}$ & 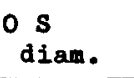 & $\begin{array}{l}0 \circ G 0 \\
\text { length }\end{array}$ & $\begin{array}{l}\text { I I A } \\
\text { width }\end{array}$ & $\begin{array}{l}\text { COROHOLA } \\
\text { height }\end{array}$ & width & $\begin{array}{l}00 \mathrm{SP} P \\
\text { length }\end{array}$ & $\begin{array}{c}0 \text { RE E } S \\
\text { width }\end{array}$ & ridges & D.E.A. & $\begin{array}{l}\text { ANTHSRIDIA } \\
\text { diame ter }\end{array}$ \\
\hline $63-1-25-8$ & $\begin{array}{l}\mathbf{N} \\
\mathbf{R} \\
\mathrm{M} \\
\end{array}$ & $\begin{array}{l}25 \\
54-152 \\
102 * 5.3\end{array}$ & $\begin{array}{l}20-32 \\
25 \div 0.6 \\
\end{array}$ & $\begin{array}{l}15 \\
315-360 \\
331+3.5\end{array}$ & $\begin{array}{l}250-270 \\
260 * 1.8 \\
\end{array}$ & $\begin{array}{l}29-32 \\
31 \neq 0.5\end{array}$ & $\begin{array}{l}43-50 \\
47 \pm 0.6 \\
\end{array}$ & $\begin{array}{l}25 \\
200-225 \\
214 \pm 1.4\end{array}$ & $\begin{array}{l}180-209 \\
194 \star 1.6\end{array}$ & $7-9$ & $\begin{array}{l}23-32 \\
28 \pm 0.5 \\
\end{array}$ & $\begin{array}{l}25 \\
144-162 \\
152 \pm 1.3\end{array}$ \\
\hline $63-1-25-8$ & $\begin{array}{l}N \\
\mathrm{R} \\
\mathrm{M}\end{array}$ & $\begin{array}{l}25 \\
50-115 \\
81=3.4\end{array}$ & $\begin{array}{l}22-31 \\
28 * 0.5\end{array}$ & $\bar{T}$ & $\overline{-}$ & - & - & $\begin{array}{l}25 \\
215-245 \\
227 \star 1.4\end{array}$ & $\begin{array}{l}192-200 \\
194 \pm 0.7\end{array}$ & $(7-) 8$ & $\begin{array}{l}25-40 \\
33 \star 0.8\end{array}$ & $\begin{array}{l}25 \\
151-187 \\
162+1.4\end{array}$ \\
\hline $61-4-4-1$ & $\begin{array}{l}\mathbf{N} \\
\mathbf{R} \\
\mathbf{M}\end{array}$ & $\begin{array}{l}15 \\
65-145 \\
104+7.0\end{array}$ & $\begin{array}{l}22-31 \\
26 \star 0.6\end{array}$ & $\begin{array}{l}15 \\
360-390 \\
373-2.1\end{array}$ & $\begin{array}{l}275-300 \\
286 \pm 2.2\end{array}$ & $\begin{array}{l}30-36 \\
35 \pm 0.6\end{array}$ & $\begin{array}{l}50-58 \\
52 \pm 0.7\end{array}$ & $\begin{array}{l}15 \\
225-235 \\
230+1.2\end{array}$ & $\begin{array}{l}195-225 \\
209 \pm 1.8\end{array}$ & $7-8$ & $\begin{array}{l}29-40 \\
34+1.1\end{array}$ & $\begin{array}{l}15 \\
173-191 \\
\end{array}$ \\
\hline $61-3-30-3$ & $\begin{array}{l}N \\
R \\
M\end{array}$ & $\begin{array}{l}10 \\
72-135 \\
104 \approx 7.7\end{array}$ & $\begin{array}{l}25-32 \\
26 \neq 0.9\end{array}$ & $\begin{array}{l}10 \\
345-375 \\
365 \pm 4.1\end{array}$ & $\begin{array}{l}260-285 \\
275 \pm 2.8\end{array}$ & $\begin{array}{l}32-43 \\
37 * 1.3\end{array}$ & $\begin{array}{l}50-58 \\
54 \pm 0.7\end{array}$ & $\begin{array}{l}10 \\
225-240 \\
230 \pm 2.1\end{array}$ & $\begin{array}{l}195-210 \\
202+2.3\end{array}$ & $7-8$ & $\begin{array}{l}27-36 \\
32 \pm 1.3\end{array}$ & $\begin{array}{l}10 \\
160-195 \\
181 \pm 2.3\end{array}$ \\
\hline $61-1-30-2$ & $\begin{array}{l}\mathrm{K} \\
\mathrm{R} \\
\mathrm{M}\end{array}$ & $\begin{array}{l}5 \\
65-125\end{array}$ & $29-32$ & $\begin{array}{l}15 \\
375-420 \\
393 \pm 3.7\end{array}$ & $\begin{array}{l}255-285 \\
273 \pm 2.2\end{array}$ & $\begin{array}{l}36-47 \\
42 \pm 0.9\end{array}$ & $\begin{array}{l}48-61 \\
54 \pm 2.0\end{array}$ & $\begin{array}{l}20 \\
200-225 \\
215^{ \pm 1.7}\end{array}$ & $\begin{array}{l}185-210 \\
199 \pm 1.4\end{array}$ & $7-8$ & $\begin{array}{l}25=40 \\
31 \pm 0.9\end{array}$ & $\begin{array}{l}15 \\
162-185 \\
174 \pm 1.6\end{array}$ \\
\hline $63-1-23-5$ & $\begin{array}{l}\mathrm{N} \\
\mathrm{R} \\
\mathrm{M}\end{array}$ & $\begin{array}{l}20 \\
63-125 \\
89+4.1\end{array}$ & $\begin{array}{l}25-32 \\
29 \pm 0.7\end{array}$ & $\begin{array}{l}10 \\
360-375 \\
368 \pm 2.5\end{array}$ & $\begin{array}{l}285-300 \\
291 \pm 2.2\end{array}$ & $\begin{array}{l}32-40 \\
36 \pm 0.9\end{array}$ & $\begin{array}{l}50-54 \\
52 \pm 0.7\end{array}$ & $\begin{array}{l}10 \\
225-235 \\
228 \pm 1.4\end{array}$ & $\begin{array}{l}200-215 \\
206 \pm 1.9\end{array}$ & $7-8$ & $\begin{array}{l}32-40 \\
36 \pm 0.9\end{array}$ & $\begin{array}{l}15 \\
155-184 \\
170 \pm 2.4\end{array}$ \\
\hline $60-8-14-2 c$ & $\begin{array}{l}\mathrm{N} \\
\mathrm{R} \\
\mathrm{K} \\
\end{array}$ & - & - & & & - & - & $\begin{array}{l}25 \\
185-230 \\
208 \pm 2.0\end{array}$ & $\begin{array}{l}170-200 \\
191 \pm 1.3\end{array}$ & $7-8$ & $\begin{array}{l}27-40 \\
33 \pm 0.7\end{array}$ & - \\
\hline $63-1-30-4$ & $\begin{array}{l}\mathrm{N} \\
\mathrm{R} \\
\mathrm{M} \\
\end{array}$ & - & & & & - & - & $\begin{array}{l}4 \\
215-240 \\
229 \pm 8.0\end{array}$ & $\begin{array}{l}185-210 \\
196 \pm 8.0\end{array}$ & 7 & $\begin{array}{l}30-40 \\
37 \pm 1.4\end{array}$ & - \\
\hline $62-4-28-6$ & $\begin{array}{l}\pi \\
\mathrm{R} \\
\mathrm{H}\end{array}$ & - & - & - & & - & - & $\begin{array}{l}10 \\
225-240 \\
230 \pm 1.9\end{array}$ & $\begin{array}{l}195-205 \\
199 \pm 1.1\end{array}$ & $7-8$ & $\begin{array}{l}29-43 \\
36 \pm 1.5\end{array}$ & - \\
\hline $63-1-23-2$ & $\begin{array}{l}\mathrm{N} \\
\mathrm{R} \\
\mathrm{M} \\
\end{array}$ & $\begin{array}{l}20 \\
32-86 \\
61 \neq 2.9\end{array}$ & $\begin{array}{l}25-32 \\
30 \pm 0.5\end{array}$ & $\begin{array}{l}10 \\
375-390 \\
381 \pm 2.6\end{array}$ & $\begin{array}{l}275-290 \\
284 \pm 2.2 \\
\end{array}$ & $\begin{array}{l}36-43 \\
38 \pm 1.1 \\
\end{array}$ & $\begin{array}{l}54-61 \\
56 \pm 1.0 \\
\end{array}$ & $\begin{array}{l}20 \\
225-240 \\
232 \neq 1.5\end{array}$ & $\begin{array}{l}200-225 \\
213 \pm 1.8 \\
\end{array}$ & $7-8$ & $\begin{array}{l}25-42 \\
33 \pm 1.0\end{array}$ & $\begin{array}{l}10 \\
165-190 \\
179 \pm 3.1\end{array}$ \\
\hline $61-4-5-2 A$ & $\begin{array}{l}\mathrm{N} \\
\mathrm{R} \\
\mathrm{M} \\
\end{array}$ & $\begin{array}{l}15 \\
50-158 \\
96 \pm 8.7 \\
\end{array}$ & $\begin{array}{l}25-40 \\
32 \pm 1.2 \\
\end{array}$ & $\begin{array}{l}10 \\
375-405 \\
387 \pm 3.9 \\
\end{array}$ & $\begin{array}{l}260-285 \\
274 \pm 2.6 \\
\end{array}$ & $\begin{array}{l}40-45 \\
42 \pm 0.6 \\
\end{array}$ & $\begin{array}{l}50-61 \\
55 \pm 1.2 \\
\end{array}$ & $\begin{array}{l}15 \\
210-240 \\
225 \neq 2.2 \\
\end{array}$ & $\begin{array}{l}185-210 \\
201 \pm 2.1 \\
\end{array}$ & $7-8$ & $\begin{array}{l}30-43 \\
35 \pm 1.1 \\
\end{array}$ & $\begin{array}{l}15 \\
158-187 \\
173 \pm 2.7\end{array}$ \\
\hline $63-1-29-1$ & $\begin{array}{l}\mathrm{N} \\
\mathrm{R} \\
\mathrm{M}\end{array}$ & $\begin{array}{l}18 \\
36-72 \\
59 \pm 2.6\end{array}$ & $\begin{array}{l}27-36 \\
32 \pm 0.7\end{array}$ & $\longrightarrow$ & 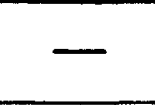 & 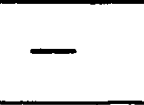 & - & $\begin{array}{l}20 \\
215-240 \\
224 \pm 1.3\end{array}$ & $\begin{array}{l}182-200 \\
192 \pm 1.4\end{array}$ & $7-8$ & $\begin{array}{l}29-38 \\
32 \pm 2.2\end{array}$ & $\begin{array}{l}14 \\
148-180 \\
162 \pm 2.8\end{array}$ \\
\hline $61-9-5-3$ & $\begin{array}{l}\mathrm{N} \\
\mathrm{R} \\
\mathrm{M}\end{array}$ & $\begin{array}{l}20 \\
35-77 \\
60 \pm 2.5\end{array}$ & $\begin{array}{l}28-40 \\
33 \pm 0.8\end{array}$ & $\begin{array}{l}5 \\
420-455 \\
437 \pm 8.1\end{array}$ & $\begin{array}{l}308-320 \\
314 \pm 2.8\end{array}$ & $\begin{array}{l}35-40 \\
38 \pm 1.2\end{array}$ & $\begin{array}{l}49-56 \\
53 \pm 1.7\end{array}$ & $\begin{array}{l}7 \\
225-250 \\
242 \pm 2.5\end{array}$ & $\begin{array}{l}207-217 \\
211 \pm 1.4\end{array}$ & $7-8$ & $\begin{array}{l}35-42 \\
40 \pm 0.7\end{array}$ & $\begin{array}{l}12 \\
154-182 \\
168 \pm 2.6\end{array}$ \\
\hline
\end{tabular}


(apparently the basic type), others were granulate but showed definite tendencies toward a reticulate condition (beaded reticulation but granules were not coalesced), and others appeared distinctly reticulate (beaded reticulation with granules partially or fully coalesced). Although quite distinct in some cases, the patterns of membrane decoration were not correlated with particular vegetative forms (Tables $15 \mathrm{~A}$ and $\mathrm{B}$ ). Measurements of antheridial diameters revealed only minor variations, comparable to those of oospore length and width, ranging from $144-195 \mu$ (mean range 152-181). The consistency in size and shape of the sexual structures of the specimens examined indicate that variations in environmental conditions have little effect on them.

A chromosome number of 9 was determined for specimens of Taxon A from 15 localities, including all states from which the species was collected (Hotchkiss, unpublished). Specimens not counted include those of collections $60-8-14-2 C, 61-4-1-2,61-9-15-1,61-4-4-4 C, 61-9-14-1$, and 61-4-4-6B. Most of these collections represent specimens gathered from or in the vicinity of the habitats of those that were observed cytologically. 


\section{TAXON B}

\section{Figures 25-26}

DESCRIPTION OF SPECIMENS (including 5 mature shoots from each collection): Plants dioecious, 5-15 cm high, moniliform, quite sturdy and rigid with Iight to heavy mucus, medium green to dark green, lightly to heavily incrusted with lime. Main axes (250-) 300-400 (-450) $\mu$ in diameter; internode length usually much exceeding that of branchlets. Branchlets up to $2 \mathrm{~cm}$ long but usually $\mathrm{ca} .1 \mathrm{~cm}$ or less, consistently 6 in a whorl, usually at least partially 4-furcate, rarely 5-furcate; primary rays straight and rather stout, $1 / 3-1 / 2 \times$ branchlet length, (0.9-) 1.5-4.5 (-6.0) mm long, 150-295 $\boldsymbol{\mu}$ in diameter; secondary rays 6-7 at a node (including percurrent ray), (0.6-) $1.0-2.5(-3.8)$ mm long when forked, 65-135 $\boldsymbol{\mu}$ in diameter, rarely simple and up to 5-celled; tertiary rays (3-) 4-6 (-7) at a node (higher numbers include percurrent ray) (0.4-) 0.6-2.2 ( -5.0 when simple) mm long, $50-90 \mu$ in diameter, frequently simple and 2-5-celled; quaternary rays when present (3-) 4-5 $(-6)$ at a node $0.2-1.5 \mathrm{~mm}$ long, 35-65 $\boldsymbol{p}$ in diameter, most frequently simple and 2-4-celled; quinary rays when present (3-) $4(-5)$ at a node, 0.3-3.2 m long, 30-50 $\boldsymbol{\mu}$ in diameter, 2-3-celled, very rarely forked again into 3-5 sexinary rays which are 2-celled. Ultimate rays (2-) 3-4 (-5) celled; penultimate cell narrow, gradually or abruptly tapering to base of ultimate cell which is a conical mucro. Mucros persistent, sharp, (43-) 65-95 (-115) $p$ long, $18-30 \mu$ in diameter. Gametangia usual1y conjoined. Oogonia on a short stalk, solitary at 2nd and 3rd branchlet nodes, $345-450 \mu$ long, $220-330 \mu$ wide; coronulae persistent $32-43 \mu$ high, 50-61 $\mu$ wide. Oospores medium to dark chestnut brown, 200-255 $\mu$ Iong, 170-225 $\mu$ wide; striae of 7-8 low but prominent ridges; D.E.A. 25-47 $\mu$; membrane coarsely granulate to reticulate (beaded). Antheridia stalked, 
Fig. 26. TAXON B (Nitella gracilis species group). A. Mature branchlet on section of main axis $(62-4-28-5), X 10$. B. Young branchlet displaying male and female gametangia $(62-4-28-9), X 20, C$. and D. Ultimate branchlet rays with characteristic mucros: C. (62-4-28-5), X 275; D. (62-4-28-9), X 275. B. and F. Habit sketchs of mature plants: E. $(62-4-28-5), \times 1 / 2$; F. $(62-4-28-9), \times 1 / 2$. 

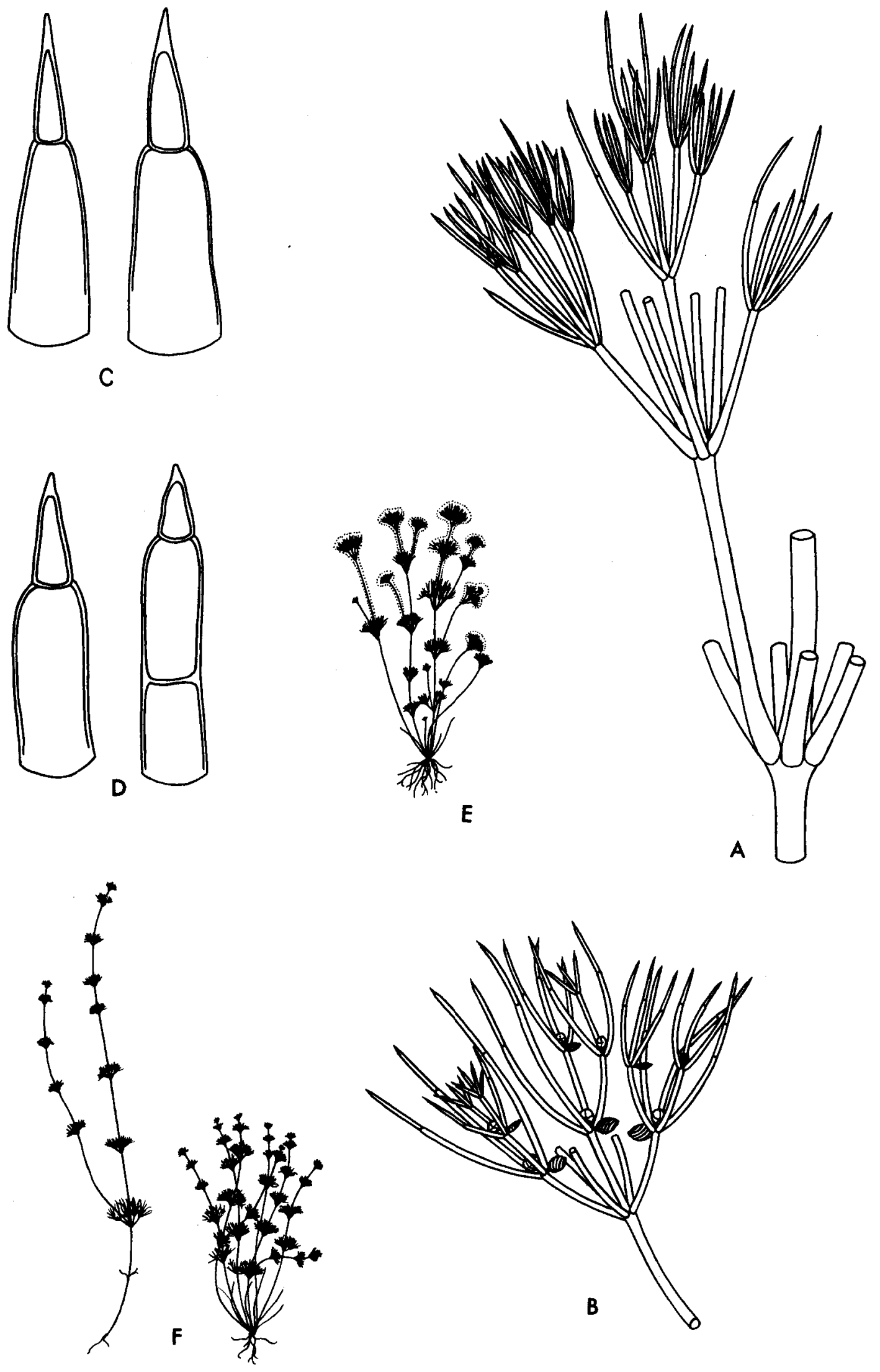
Fig. 25. TAXON B (N1tella gracilis species group). A. and B. Mature branchlets $(62-4-28-7), \times 10$. C. Sterile branchlet from lower part of plant (61-3-29-1), X 10. D. Habit sketch of mature plant; displaying gelatinous substance around upper whorls $(62-4-28-7), X 1 / 2$. E. UItimate branchlet rays with characteristic moros (62-4-28-7), $\mathrm{X} 275$. 


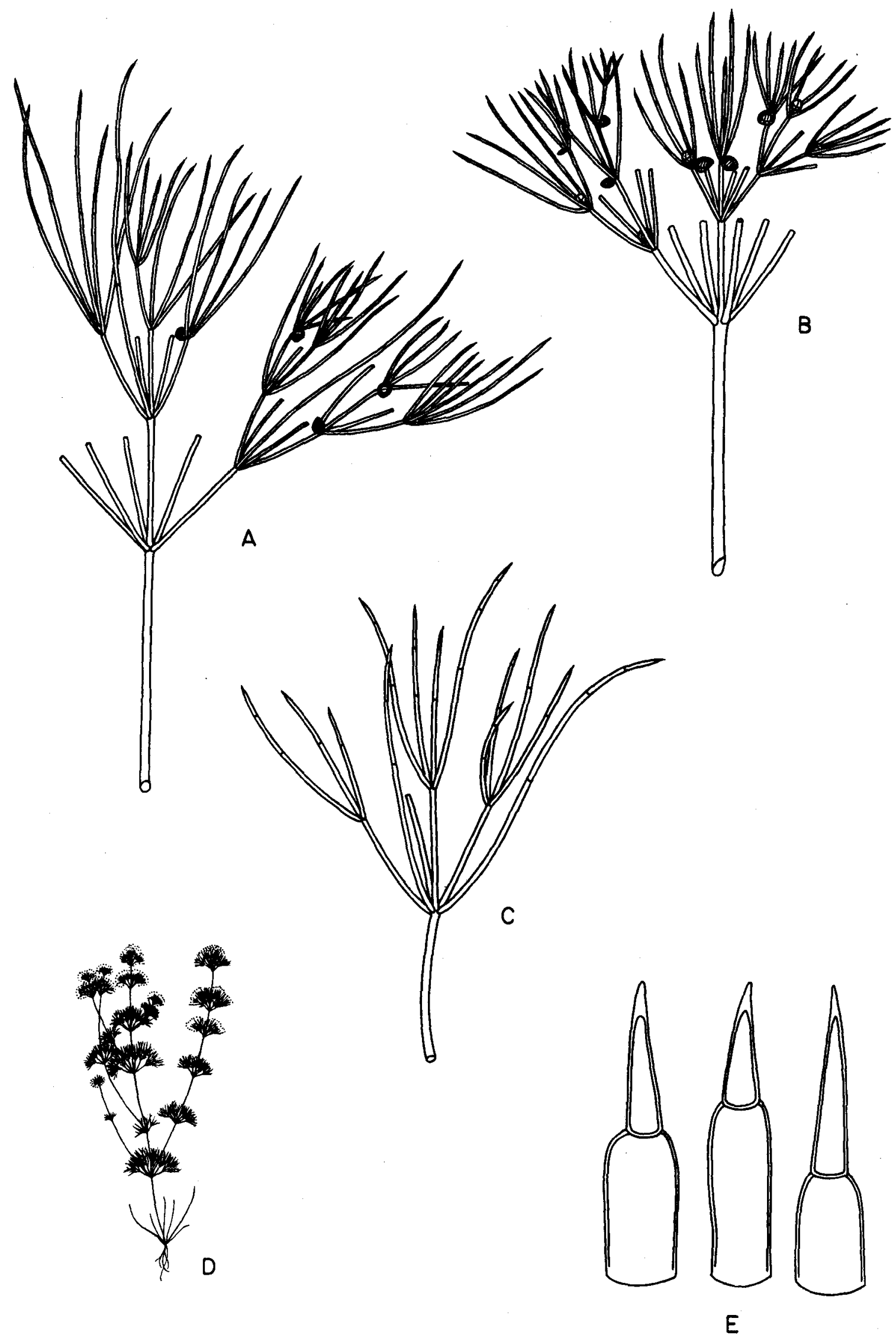


solitary at 2nd and 3rd (rarely at lst and 4th) branchlet nodes, 148-255 $p$ in diameter, 8-scutate.

SPECTMENS EXAMINED: OKIAHOMA: (60-8-14-2A, 61-3-29-1, and 62-4-28-9) scattered tufts in current between 0.3-0.5 mi. above Turner's Falls, Honey Creek, Murray Co., Oklahoma, D. Tindall, W. Minckley, and J. Craddock, Aug. 14, 1960; D. Tindall and W. Minckley, March 29, 1961; D, Tindall, A. Hotchkiss, and W. Minckley, April 28, 1962. (61-3-29-5 and 62-4-28-7) Large tributary to Honey Creek, below Turner's Falls, Murray Co., Oklahoma, D. Tindall and W. Minckley, March 29, 196I; D. Tindall, A. Hotchkiss, and W. Minckley, April 28, 1962. (62-4-28-5) Antelope Spring, Platt National Park, Murray Co., Oklahoma, D. Tindall, A. Hotchkiss, and W. Minckley, April 28, 1962.

DISTRIBUTION: The above collections represent the only known records of Taxon $B$. These collections were made in a very limited area in south-central Oklahoma (Fig. 24). This form doubtlessly has a wider distribution than is indicated by the present collections. However, the failure to discover the Nitella in other parts of the study area indicates that it may have a rather localized distribution or that the presently known localities may represent the southern limits of its geographical range.

BCOLOGY: Physicochemical features of the habitats.-Taxon B was observed only in cool, clear, shallow waters of limestone streams (Table 16). The Nitella occurred in waters with flow ranging from very slow to 
Table 16. Physioochemical features of the habitats supporting Taxon B (Nitella gracilis species group).

\begin{tabular}{|c|c|c|c|c|c|c|c|c|c|c|c|}
\hline Specimens & Locality & Habitat & Substrate & Depth & $\begin{array}{l}\text { Tur- } \\
\text { bidity }\end{array}$ & Light & $\begin{array}{l}\text { Tompe } \\
\text { air }\end{array}$ & $\begin{array}{l}\text { rature } \\
\text { water }\end{array}$ & $\mathrm{pH}$ & Alk. & $\mathrm{CO}_{2}$ \\
\hline $62-4-28-9$ & Oklahcma & swift $s$ troam & $\begin{array}{l}\text { compact } \\
\text { marl }\end{array}$ & $0.05-0.3$ & 0 & $\begin{array}{l}\text { open d } \\
\text { shaded }\end{array}$ & 25.0 & 20.0 & 8.2 & 253 & 2.5 \\
\hline $62-4-28-7$ & Oklahoma & $\begin{array}{l}\text { slow-flowing } \\
\text { s tream }\end{array}$ & soft marl & $0.10-0.3$ & 0 & $\begin{array}{l}\text { open } \\
\text { shaded }\end{array}$ & 27.0 & 23.0 & 8.11 & 265 & 3.5 \\
\hline $62-4-28-5$ & Oklahoma & $\begin{array}{l}\text { s low-flowing } \\
\text { s tream }\end{array}$ & $\begin{array}{l}\text { marl- } \\
\text { gravel }\end{array}$ & $0.05-0.25$ & 50 & $\begin{array}{l}\text { open \& } \\
\text { shaded }\end{array}$ & 25.0 & 17.5 & 7.4 & 333 & 26.0 \\
\hline
\end{tabular}


swift. All of these waters were quite similar chemically, being characterized by an alkaline $\mathrm{pH}$, a high alkalinity, and a low to high free carbon dioxide content (Table 16). Like Taxon A, the present form was frequently heavily incrusted. Although microenvironmental conditions might have been conducive to extensive lime incrustation (see above), there also exists the possibility that variations in the chemical characteristics of the main body of water in the various streams were of a much wider range than was indicated by the analyses made at the time of collection (see Tindall and Minckley, 1964).

Plant communities.-Taxon B was observed in Honey Creek on August 14, 1960, March 29, 1961, and April 28, 1962. The species was observed in the tributary to Honey Creek on the same dates in March 1961 and April 1962 (locality was not examined in 1960). Thus, the species is quite stable and may well be perennial in those streams. As mentioned above, Taxon A was also observed in Honey Creek and Antelope Spring. Of the three surveys made on Honey Creek, only the first in August 1960 produced a small amount of Taxon A. Bach of the surveys revealed an abundance of Chara contraria in the ponded areas. Isolated tufts of Taxon A and Taxon B were abundant in the ponded area of Antelope Spring. No other macrophytes were observed in direct association with the Nitellas. The tributary to Honey Creek supported a well developed charophyte community in March 1961, consisting of numerous tufts of Taxon B in the swifter waters and large stands of Chara contraria and Tolypella sp. in the pools. In April 1962, only a single rather old shoot of Tolypella was present, but Nitella and Chara were abundant. MORPHOLOGY AND CYTOLOGY: The range of variation in vegetative morphology displayed by specimens of Taxon B is included in the description. A separate analysis of specimens from each of the three 
localities is included in Table 17. Marked differences were not apparent but minor differences in size and number of branchlet rays, length of mucros, and amounts of mucus were observed between specimens from Honey Creek (62-4-28-9) and the other two localities (tributary to Honey Creek, 62-4-28-7 and Antelope Spring, 62-4-28-5). Variations in gametangial and oospore morphology followed the same general pattern (Table 17). Specimens from Honey Creek displayed markedly smaller gametangia and oospores than those from the tributary.

All variations noted above can be correlated with differences in chromosome numbers of the various specimens. A chromosome number of 9 was determined from specimens of collections $60-8-14-24,61-3-29-1$, and 62-4-28-9; all of which were gathered from the same population in Honey Creek. Specimens from remaining collections of Taxon B (61-3-29-5 and 62-4-28-7 from the tributary to Honey Creek, and 62-4-28-5 from Antelope Spring) revealed 18 chromosomes.

DISCUSSION: A comparison of the descriptions, illustrations, and corresponding tables reveals the basic similarities and differences between Taxon A and Taxon B. However, the exclusion of data on 9-chromosome forms of Taxon B would serve to markedly distinguish the two taxa, possibly at the species level. The 18-chromosome form of Taxon $B$ was easily distinguished from Taxon A in Antelope Spring where they grew side-by-side but specimens of Taxon B with 9 chromosomes were less easily distinguished from Taxon A in Honey Creek. The similarities of 9-chromosome representatives of Taxon B to Taxon A are limited primarily to gametangial and oospore morphology. Vegetative morphology, especially the number of cells in the ultimate branchlet rays and occasional mucus doubtlessly align the plants more closely to the 18-chromosome form of 
Tabl. 17. A comparison of specimens of Taxon B (Hitella gracilis epecies group) with 9 and 18. chromosones.

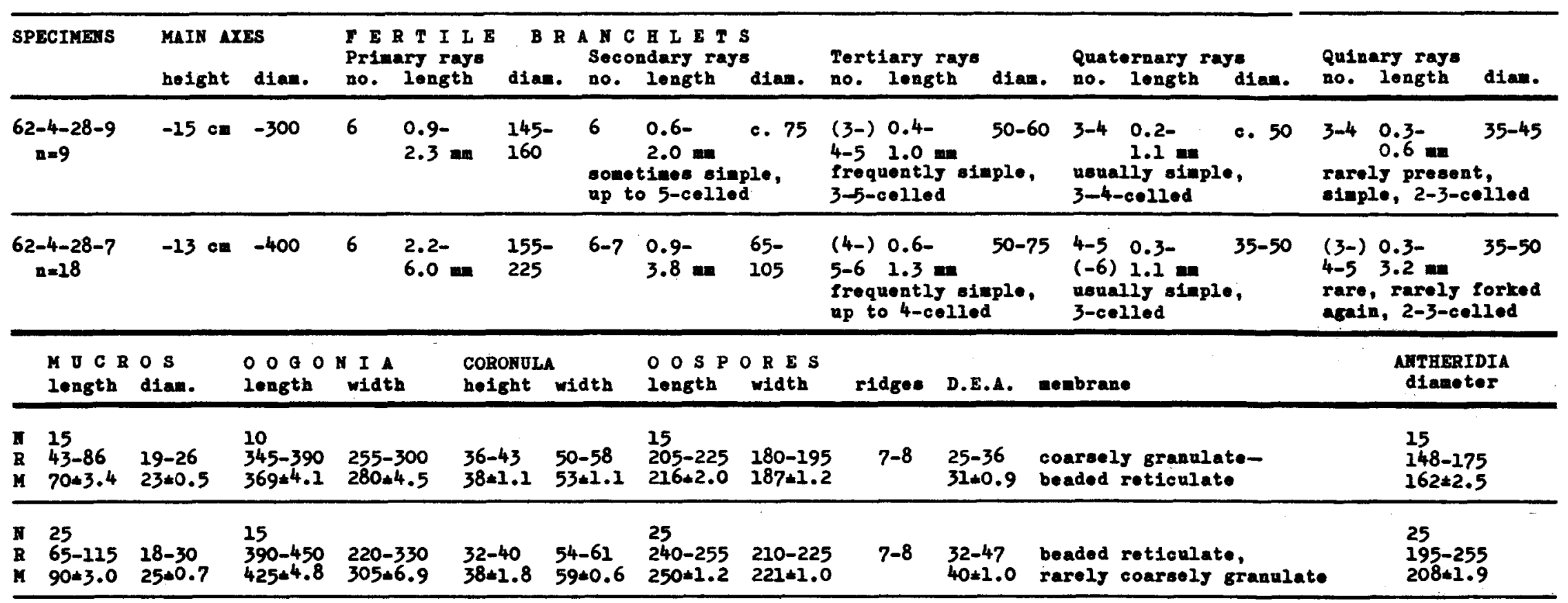


Taxon B. In any case, from a morphological standpoint the specimens of Taxon B with 9 chromosomes occupy a somewhat intermediate position between Taxon A and Taxon B (with 18 chromosomes).

The actual relationships between the two taxa are problematical. At present, it appears that one of three possible courses of evolution has led to the present state of the complex. Firstly, that a basic form, presumably Taxon A-like, has become differentiated into two types (Taxon A and Taxon B, both with 9 chromosomes). The known distribution of the two taxa indicates that such differentiation could have resulted from geographical isolation. The simplest explanation of the origin of Taxon B with 18 chromesomes is that it is an autopolyploid product of the 9-chromosome form of Taxon B. Secondly, that Taxon A and Taxon B (9 chromosomes) originated from the same basic stock, and that Taxon B (18 chromosomes) is a polyploid product of hybridization between them. Finally, that Taxon $A$ and Taxon $B(18$ chromosomes) represent the original products of differentiation from a basic stock and that Taxon B ( 9 chromosomes) is a product of hybridization between those forms.

The data and discussion included above demonstrate the complexity of this section of the Nitella gracilis species group. This along with the fact that several previously described forms doubtlessly must be referred here have caused me to refrain from supplying particular names to the taxa described above. Until further collections are made and type specimens are examined these taxa are referred to a single unnamed species. It is quite apparent, however, that the specimens included here represent at least two distinct taxa, possibly referable to separate species. 
NITEIIA HYALINA (De Candolle) Agardh

Figure 27

Chara hyalina De Candolle (1815:247).

Nitella hyalina Agardh (1824:126).

N. formosa Allen (1893:119).

IITERATURE FOR THE STUDY ARRA: Braun and Nordstedt (1882), Allen (1892), Wood (1948), Allen (1954), and Horn af Rantzien (1950).

DESCRIPTION OF SPECIMENS (including 5 plants from each collection except from the North Carolina locality, see Wood, 1954): Plants nonoecious, $9.0-38.0 \mathrm{~cm}$ high, distinctly moniliform, tufted, very sturdy, dull green to dark green, with heavy mucus on upper parts, moderately to heavily incrusted with lime (conspicuous at tips of branchlets). Main axes $345-650 \mu$ in diameter, intermodes much longer than branchlets except at young tips. Branchlets of 2 types: PRIMARY BRANCHLETS (7-) 8 in a whorl, 0.8-1.8 cm long, usually 3-furcate but sometimes 4- and rarely 5-furcate; primary rays (7-) 8 , usually ca. $2 / 3$ branchlet length, 4.5-11.5 mm long, 170-200 in diameter; secondary rays 10-15 on each primary ray, of which 6-7 (percurrent ray sometimes present) are first order rays and the remainder are accessories, all except 1-3 are again forked, 0.8-3.6 m long, simple ones $0.5-1.2 \mathrm{~mm}$ long; tertiary rays (4-) 6-7 (-8), 1-4 are again forked, 0.8-1.9 m long, simple ones 0.5-1.3 mm long; quatemary rays (3-) 4-6 (-8), occasionally again forked, 0.8-1.1 mm long; quinary rays (4-) $5(-6)$ very rarely forked forming 4-5 sexinary rays. ACCESSORY BRANCHLETS occurring above and below primary branchlets, of variable number, size, and complexity; 11-39 at a node, to $1.1 \mathrm{~cm}$ long; simple to 4-furcate (usually 1- or 2-furcate); primary rays $1.0-2.0 \mathrm{~mm}$ long; tertiary rays (4-) 5-6 (-9), 0.8-1.3 mm long; quaternary rays (not common on all specimens) $5-6, \mathrm{ca} .1 .0 \mathrm{~mm}$ long. 
Figure 27. Nitella hyalina $(63-1-24-3)$. A. Young fertile branchlet displaying characteristic gelatinous envelopment, X 24. B. Mature whorl of branchlets from lower part of plant including primary and accessory branchlets, X 5. C. Ultimate branchlet ray with characteristic mucro, X 275 . 


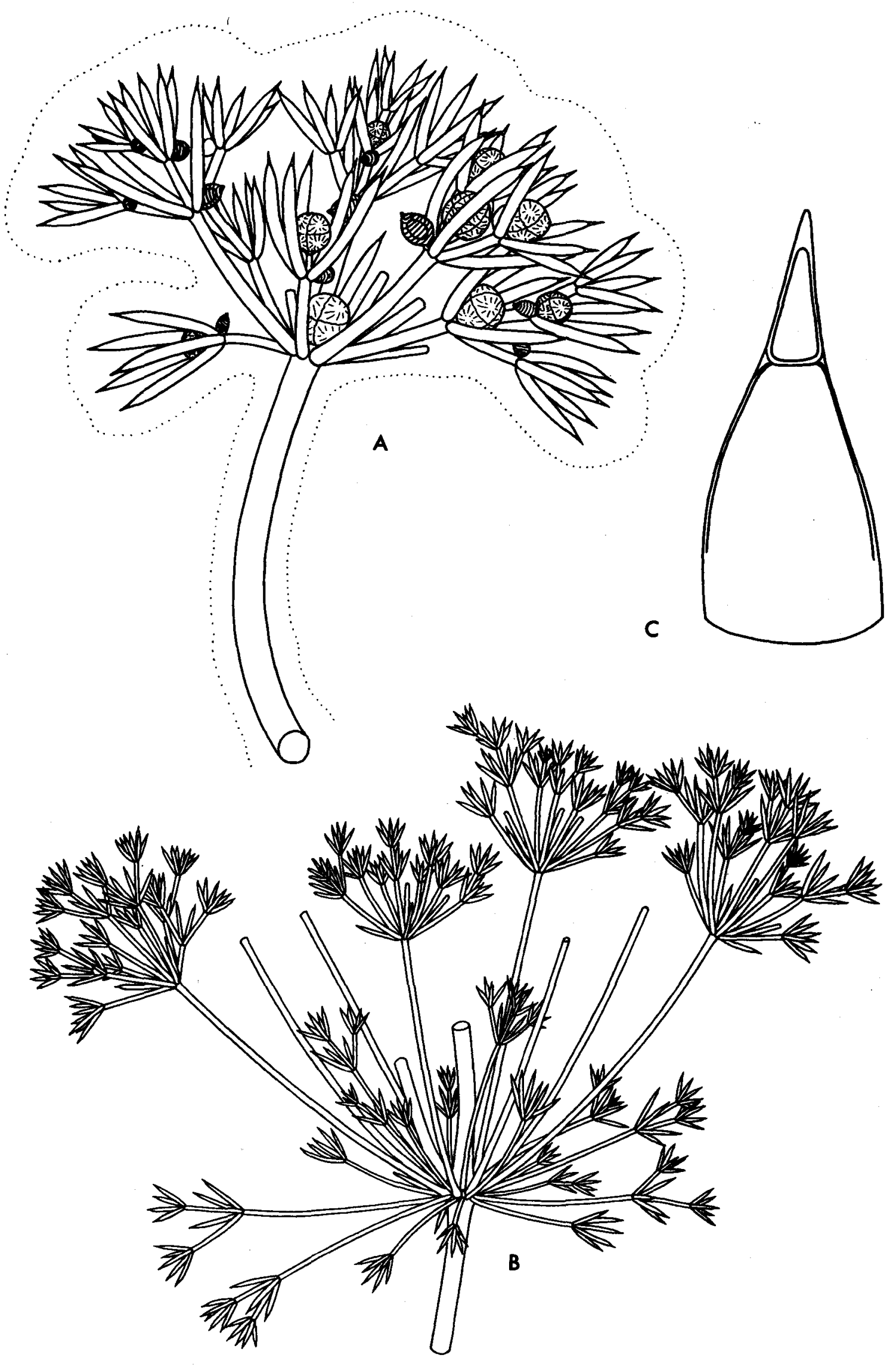


Ultimate rays always 2-celled; ultimate cell a short conical mucro 40-115 $\mu$ long, 25-40 $\mu$ wide at base; penultimate cell elongate, gradually tapering to base of mucro. Gametangia solitary or conjoined at first 3 (sometimes 4) branchlet nodes (lacking at first node when percurrent ray is present). Oogonia usually solitary, sometimes 2 at a node, 435-540 $\mu$ long, 330-405 $\mu$ wide, sheath cells slightly elongate and spread apart at apex but converged at base of coronula; coronulae persistent, 40-58 $\mu$ high, 58-72 $\mu$ wide, upper cells $2 \mathrm{X}$ the length of lower ones. Oospores medium ruddy-brown to dark chestnut-brown, 260$335 \mu$ long, $240-315 \mu$ wide; striae of (6-) $7(-8)$ prominent ridges (not flanged); D.E.A. 36-58 $\mu$; membrane appearing finely granulate under low magnification but is covered with numerous minute lacunae which sometimes appear as a very fine reticulation. Antheridia bright orangered, solitary, sessile or on a short stalk, 285-375 $\mu$ in diameter, 8-scutate.

SPECIMENS BXANINED: NORTH CAROLINA: (61-10-6-1) Iake Mattamuskeet, W side of State Hwy 94, just $N$ of West Main Canal, Hyde Co., North Carolina, A. Hotchkiss, D. Tindall, and T. Sawa, Oct. 6, 1961. TEXXS: (64-12-4-1) Pond, near Rio Grande Village Campground, Big Bend National Park, Brewster Co., Texas, T. Sawa and V. Proctor, Dec. 4, 1964.

TAMAULIPAS: (63-1-23-6) Iow-water pool of the Rio Purificacion, near bridge at Padilla, Tamaulipas, Mexico, D. Tindall and A. Hotchkiss, Jan. 23, 1963. (63-1-29-5) Rio Guayalejo (headwaters of Rio Tamesi), 30 mi. N Cd. Mante, Mex. Hwy 85, Tamaulipas, Mexico, D. Tindall and A. Hotchkiss, Jan. 29, 1964. (63-1-24-1) Shallow roadside pool, $10 \mathrm{mi}$. E Cd. Mante, State Hwy 80, Tamaulipas, Mexico, D. Tindall and A. Hotchkiss, 
Jan. 24, 1963. (63-1-25-9) Arroyo, 16 mi. S Cd. Mante, Mex. Hwy 85, Tamaulipas, Mexico, D. Tindall and A. Hotchkiss, Jan. 25, 1963.

SAN LUIS POTOSI: (61-9-9-2) Small limestone arroyo flowing W, 31 mi. S Cd. Mante, Mex. Hwy 85, San Luis Potosi, Mexico, D. Tindall, A. Hotchkiss, and R. Goodyear, Sept. 9, 1961. (61-9-8-7A and 63-1-25-4) Arroyo, $17 \mathrm{mi}$. N Cd. de Valles, Mex. Hwy 85, San Luis Potosi, D. Tindall, A. Hotchkiss, and R. Goodyear, Sept. 8, 1961; D. Tindall and A. Hotchkiss, Jan. $25,1963$.

VERA CRUZ: (63-1-24-3) Shallow pool along south side of Mex. Hwy 110, 2 mi. W Rio Tamesi, just W Tampico, Vera Cruz, Mexico, D. Tindall and A. Hotchkiss, Jan. 24, 1963.

TYPE LOCALITY: Europe (De Candolle, 1805).

DISTRIBUTION: Nitella hyalina is a cosmopolitan species, occurring on every major continent (Wood and Imahori, 1959). The species occupies one of the widest geographical ranges known in the plant kingdom, ranging from $70^{\circ} \mathrm{N}$ to $40^{\circ} \mathrm{S}$ (Zaneveld, 1940). Prior to the present study, only 6 localities in North America were known to support the species. These included North Carolina (University Lake, Chapel Hill, Orange Co., Stewart, 1937; Lake Mattamuskeet, Hyde Co., Wood, 1954); Texas (Braun and Nordstedt, 1882): Mexico (Toalnepantla, Mexico, Allen, 1893); and Cuba (Braun and Nordstedt, 1882)。

The distribution of $\mathrm{N}$. hralina in the study area is show in Figure 28. The present records do not extend the range of the species in North America but do show that it is much more common than suspected. Based on available data the species appears to follow the eastern coastal lowlands but it extends 400 miles inland to an elevation of ca. $700 \mathrm{~m}$ in Brewster County, Texas. The maximum elevation at which the species is known to occur in North America is ca. $2400 \mathrm{~m}$ in south-central Mexico. 


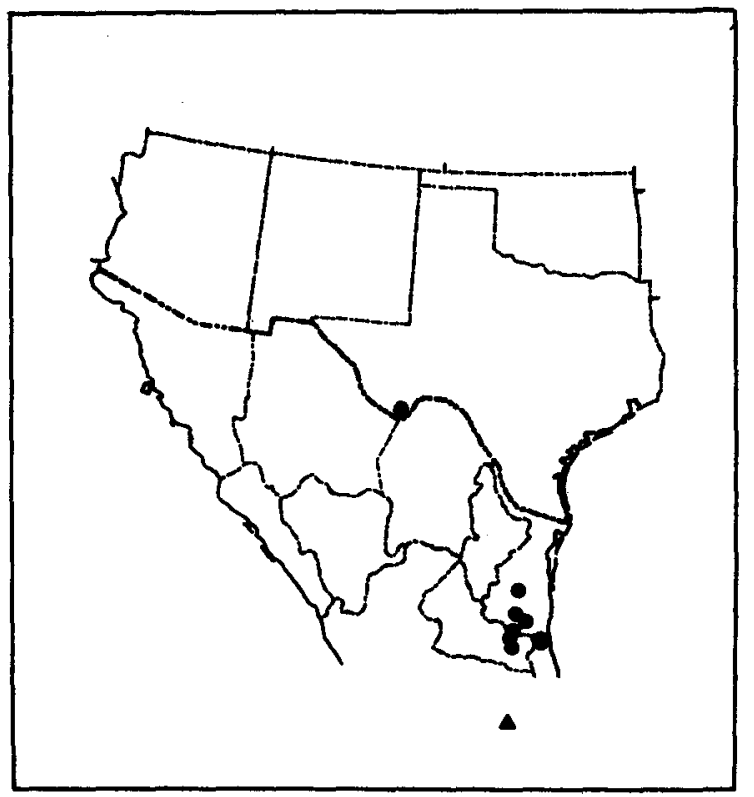

Fis. 28. Distribution of Nitella hyalina in the study area; localities examined during the present study, $\Delta$ locality reported in the Iiterature. 
Since N. hyalina occupies such a wide geographical range and variety of habitats throughout the world, very little can be concluded regarding its presently known distribution in North America. Further collecting on this continent will doubtlessly reveal a more widespread distribution of the species. However, extensive investigation of apparently suitable habitats in other parts of the study area did not yield the species.

\section{BCOLOGY: Physicochemical features of the habitats.--A summary} of various physical and chemical features of the habitats supporting Nite 17a hyalina is included in Table 18. The species occurred in a variety of habitats but most were relatively small shallow bodies of water. It occurred only in still or very slightly agitated waters of the stream localities. Substrates were fine textured (clay or silt) associated with marl granules or sand. The substrates also contained various amounts of organic material. The shallow waters displayed variations in temperature closely following those of air temperature, resulting in extremes of 9.5 to $30.0 \mathrm{C}$. All but one of the Mexican localities supporting N. hyalina in January 1963 did not contain the species in September 1961, but maintained luxuriant stands of Chara zeylanica during the September survey. These observations indicate that the species is an unsuccessful competitor with the Chara during the warmer months, whereas, the reverse is true during the cooler seasons. Iight conditions were similar in all of the habitats; all but the North Carolina locality contained clear water, and all were completely open to maximum insolation. Alkalinity and chlorides in the waters varied considerably, whereas, $\mathrm{pH}$ was relatively constant throughout the range of the species. 
Table 18. Physicochemical features of habitats supporting Nitella hyalina.

\begin{tabular}{|c|c|c|c|c|c|c|c|c|c|c|c|}
\hline Specimens & Locality & Habitat & Subs trate & Depth & $\begin{array}{l}\text { Tur- } \\
\text { bidity }\end{array}$ & Iight & $\begin{array}{l}\text { Tempe } \\
\text { air }\end{array}$ & $\begin{array}{l}\text { rature } \\
\text { water }\end{array}$ & $\mathrm{pH}$ & Alk. & $\mathrm{CO}_{2}$ \\
\hline $61-10-6-1$ & $\begin{array}{l}\text { North } \\
\text { Carolina }\end{array}$ & shallow lake & sand-silt & $0.20-0.5$ & + & open & 23.0 & 20.0 & 7.5 & 22 & 1.0 \\
\hline Wood (1954) & \multicolumn{2}{|c|}{ same as above } & & & - & . & & - & $\begin{array}{l}7.1- \\
7.8\end{array}$ & $\begin{array}{l}30- \\
40\end{array}$ & 5.0 \\
\hline $64-12-4-1$ & Texas & pond & $\operatorname{marl}$ & $0.30-0.5$ & 0 & open & 4.0 & 10.0 & & & \\
\hline $63-1-23-6$ & Tamaulipas & river pool & mud-silt & $0.15-0.3$ & 0 & open & 23.0 & 20.0 & 8.0 & 153 & 8.0 \\
\hline $63-1-29-5$ & Tamaul1 pas & river pool & sand-silt & $0.05-0.1$ & 0 & open & 23.0 & 20.0 & 7.4 & 118 & 9.0 \\
\hline $63-1-24-1$ & Tamaulipas & pool & olay-mud & $0.20-0.4$ & 0 & open & 9.0 & 9.5 & 7.8 & 177 & 5.0 \\
\hline $63-1-25-9$ & Tamaulipas & stream pool & marl-clay & $0.30-0.5$ & 0 & open & 25.0 & 20.0 & 7.3 & 162 & 16.0 \\
\hline $61-9-9-2$ & $\begin{array}{l}\text { San Luis } \\
\text { Potosi }\end{array}$ & stream pool & marl-olay & $0.30-0.5$ & 0 & open & 34.0 & 30.0 & 7.85 & 193 & 5.5 \\
\hline $61-9-8-74$ & $\begin{array}{l}\text { San Luis } \\
\text { Potosi }\end{array}$ & strean pool & marl-clay & $0.20-0.3$ & 0 & open & 28.0 & 30.0 & 7.3 & 167 & 16.2 \\
\hline $63-1-25-4$ & $\begin{array}{l}\text { San Luis } \\
\text { Potosi }\end{array}$ & stream pool & marl-clay & $0.20-0.4$ & 0 & open & 28.0 & 21.0 & 7.2 & 315 & 38.5 \\
\hline $63-1-24-3$ & Vera Cruz & pool & clay-mud & $0.40-0.6$ & 0 & opon & 12.0 & 14.0 & 8.5 & 88 & 0.0 \\
\hline
\end{tabular}


Plant communities. - Vascular plants rarely occurred in direct association with Nitella hyalina. The species was regularly observed as isolated tufts sparsely or densely distributed among several other charophytes (Table 19). Species most commonly associated with N. hyalina were N. acuminata and Chara zevlanica.

MORPHOLOGY, CYTOLOGY, AND TAXONOMY: The total range in size and number of mature plant parts is included in the description of the species. Minor variations in vegetative characters between separate populations of Nitella hyalina were limited to degree of branchlet furcation and number of accessory branchlets. Measurements of gametangia and mucros of four specimens from the study area are compared with previously published measurements of the species (Table 20). Of particular interest are the measurements given by Wood and Imahori (1964) for the lectotype of N. formosa (N. hyalina) from Tlalnepantla, Mexico (Allen, 1893). These measurements are nearly identical with those of the present specimens from Mexico. Measurements recorded for the species from Iake Mattamuskeet, North Carolina (Wood, 1954) also show a remarkable similarity to those of the present study.

Chromosome counts have been made on specimens from collections 61-10-6-1 and 61-9-9-2 (Hotchkiss, 1965). Both displayed 18 chromosomes, exclusively. To Sawa (unpublished) observed somewhat abnormal divisions in cultured specimens of collection 64-12-4-1. A chromosome number of 18 was rarely observed, whereas, numbers of $36, \mathrm{ca} .45$ and ca. 70 were comnon. The cause of such a degree of polyploidy appears to have been a result of an abrupt change in temperature. (Sawa, unpublished). Chromosome counts of 18 have been reported for the species from Burope (Guerlesquin, 1963) and from New Caledonia (Hotchkiss, 1965). A basic 
Table 19. Other charophytes found growing in association with Nitella hyalina.

\begin{tabular}{|c|c|}
\hline Nitella hyalina & Other charophytes \\
\hline $61-10-6-1$ & Nitella acuminata, N. tenuissime, Chara zeylanioa \\
\hline $64-12-4-1$ & Chara contraria \\
\hline $63-1-23-6$ & Nitella gracilis sp. group \\
\hline $63-1-24-1$ & None \\
\hline $63-1-25-9$ & Nitella gracilis sp. group, N- oligospira, Chara contraria \\
\hline $61-9-9-2$ & 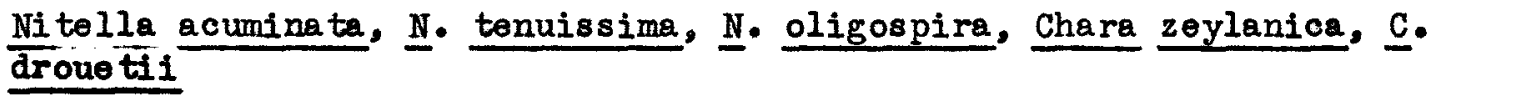 \\
\hline $61-9-8-74$ & Nitella acuminata, N. oligospira, Chara zeylanica \\
\hline $63-1-25-4$ & $\frac{\text { Nitella acuminata }}{\text { c. Nontraria }}$ ․ oligospira, $N$. gracilis sp. group, Chara zeylanica, \\
\hline $63-1-24-3$ & Chara hornemannii, C. zeylanica \\
\hline
\end{tabular}


Table 20. A comparison of gametangia, oospores, and mucros of Nitella hyalina from various localities in North merica.

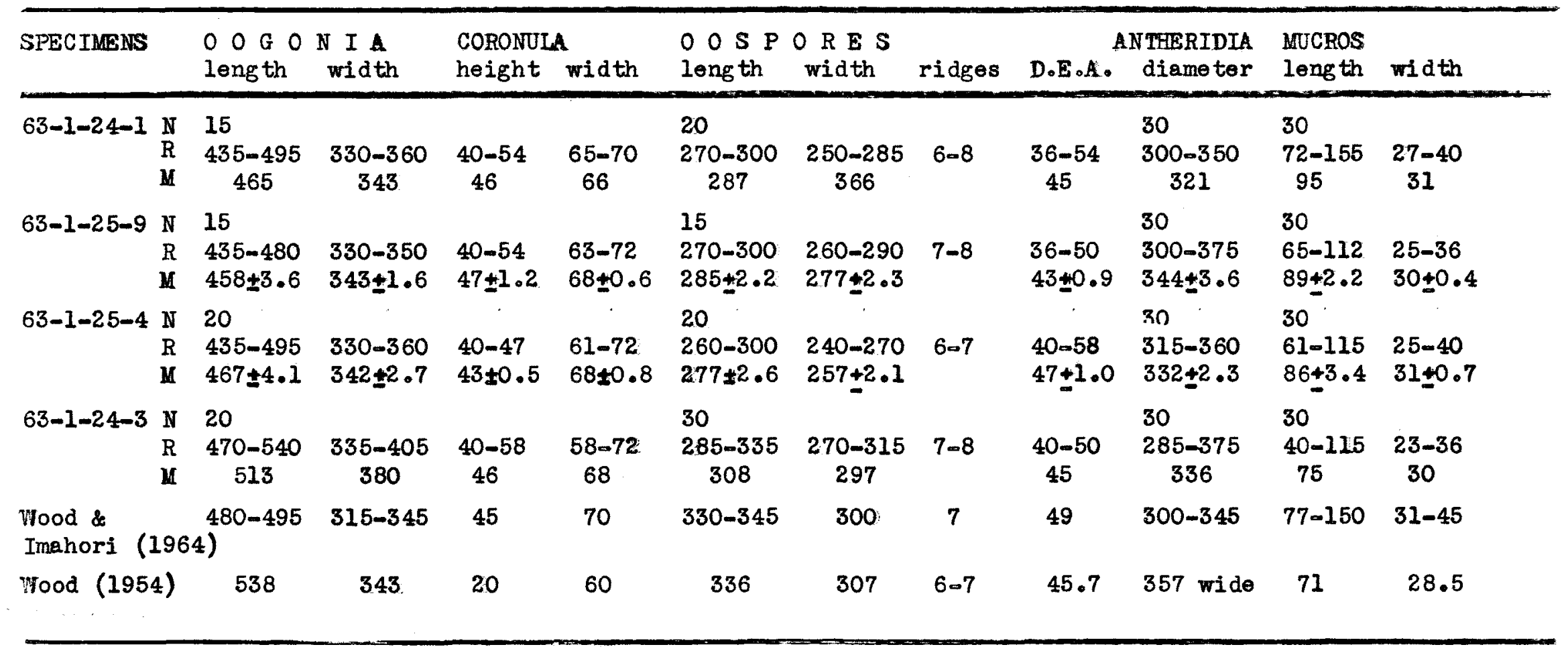


chromosome number of 18 for $\underline{N}$. hralina is convincingly verified; however, numbers less than 18 have been reported for the species. Gillet (1959) reported a number of 16 and Sato (1959) reported numbers of 12,14 , and 18 .

Taxonomically, N. hyalina is distinct from all other charophytes known to occur in North America. Usually, the species can be distinguished by its moniliform habit and heavy mucus on terminal whorls, and conclusive determination can be made based on its three or more furcate primary branchlets and numerous accessory branchlets. 
KEY TO SPECIES OF CHARA

The following is a key to the species of Chara known to occur in the study area. Species belonging to the $\mathrm{C}$. vulgaris species group are not treated separately in the key. All species, except $\underline{C}$. sejuncta and C. Cienegaensis, of the $\underline{C}$. zeylanica species group are also treated under the group name. Species included in the key but not discussed in the text are $\underline{C}$. buckellii Allen, $\underline{C}$. canescens Desvaux and Loiseleur, and $\underline{C} \cdot \underline{\text { evoluta }}$ Allen. These species have not been reported from the study area, but Vermon Proctor (personal communications) recently found them in New Mexico.

la. Stipulodes in a single tier (haplostephanous). - . - . . . 2 2a. Cortex absent. . . . . . . . . . 2b. Cortex present . . . . . . . . . . . . . 3

3a. Plants monoecious, branchlets with 1 or more segments (excluding basal I) corticated (some branchlets totally uncorticated), habit delicate. - . - $\underline{\text { C. hydropitys }}$

3b. Plants dioecious, branchlets totally uncorticated, habit stout, - . - . - . - . . - 4

4a. Plants 30 or more $\mathrm{cm}$ high, stipuledes twice as numerous as branchlets, spine cells well developed (2-8 mrm long) . . . . . . - . . hornemannii

4b. Plants less than $15 \mathrm{~cm}$ high, stipulodes equal in number to branchlets, spine cells rudimentary

1b. Stipulodes in two tiers (diplostephanous) . . . . . . . . 5 5a. Axial cortex of a single primary series (haplostichous), spine cells fasciculate • . . . . . . . . 6 6a. Plants dioecious . . . . . . .. . canescens 
6b. Plants monoecious. - . . . . - ․ evoluta

5b. Axial cortex of 2 series, 1 primary alternating with $I$ secondary (diplostichous) or of 3 series, 1 primary alternating with 2 secondaries (triplostichous), spine cells usually solitary, sometimes fasciculate . . . . . 7 7a. Axial cortex diplostichous. - $\quad$ C. vulgaris sp. group 7b. Axial cortex triplostichous . . . . . . 8 8a. Basal branchlet segrnent always uncorticated . 9 9a. Gametangia normally sejoined (at different nodes of same branchlet) . . . . . . 10 10a. Branchlet segments more than 12 , oospores $585-690 \mu$ long. . . . . 10b. Branchlet segments less than 10, oospores 335-440 $\mu$ long. • • • . . 11 11a. Mature axial internodes ca. $300 \mathrm{u}$ in diameter, branchlets less than $1 \mathrm{~cm}$ long, spine cells rudimentary, oospores 335-390 $\mu$ long. - - $\underline{\text { C. drouetij }}$ 11b. Mature axial internodes ca. $700 \mu$ in diameter, branchlets $1-3.1 \mathrm{~cm}$ long, spine cells abundant $340-515 \mu$ long, oospores $390-440 \mu$ long. . . . - . . . . $\underline{\text {. cienegaensis }}$

9b. Gametangia conjoined (at same node of branchlet) - . . . . . C. zeylanica sp. group

8b. Basal branchlet segment always corticated . . . 12 12a. Plants dioecious, spine cells and stipulodes well developed . . . . . . . . . aspera 
12b. Plants monoecious, spine cells obscure, stipulodes obscure or developed . . . . . . 13 13a. Stipulodes well developed; oospores golden brown, 427-502 $\mu$ long - . . leptosperma 13b. Stipulodes obscure or slightly developed; oospores dark brown, 540-750 $\mu$ long

- . . . . . - C. globularis 
CHARA BRAUNII Gmelin

Figures 29-30

Chara braunti Gmelin (1826:646).

C. coronata Bischoff $(1828: 26)$.

C. coronata subsp. schweinitzii Braun (1834:353).

C. schweinitzii Kutzing (1857:31).

C. pallida Robinson (1906:258).

Charopsis braunii Kutzing (1843:319).

LITERATURE FÖR THE STUDY AREA: Braun and Nordstedt (1882), Allen (1882), Robinson (1906), Zaneveld (1940), Horn af Rantzien (1950), Ophel (1952), Hevly (1961), and Griffin (1963). See also Daily (1944), Daily and Kiener (1956), and Allen (1951).

DESCRIPTION OF SPECIMENS (including aIl specimens examined): Plants monoecious, 10-45 $\mathrm{\mu} \mathrm{high,} \mathrm{light} \mathrm{to} \mathrm{dark} \mathrm{glossy} \mathrm{green,} \mathrm{lime} \mathrm{incrustation}$ ranging from none to heavy, in distinct bands. Main axes 650-835 $\mu$ in diameter, cortex and spine cells absent. Stipulodes haplostephanous, equal in number to, and alternating with branchlets, 225-2580 $\mu$ long, acuminate, sometimes wanting. Branchlets variously curved, (7-) 8-10 (-11) in a whorl, mature ones ranging from $1.0-4.7 \mathrm{~cm}$ long, $1 / 3$ to $I \mathrm{X}$ internode length; consisting of (3-) 4-5 (-6) ecorticate segments, all elongate except the short acuminate terminal one which along with 2-3 similar cells form a small crown at distal end of branchlets. Bract-cells of variable length and number; anteriors 2, 300-1935 $\mu$ long, acuminate; posteriors (incl. those in lateral position) (1-) $2(-3), 150-1290 \mu$ long, acuminate. Bracteoles 2 per oogonium and associated antheridium, 215-1290 $\mu$ long, acuminate. Gametangia conjoined at first (1-) $2(-3)$ branchlet nodes. Dogonia solitary or gaminate, 750-937 $\mu$ long, 405-585 $\mu$ wide, coronula tight or spreading, $105-165 \mu$ high, 180-240 $\mu$ wide. Oospores dark brown 
Fig. 29. Chara braunii f. novi-mexicana (64-8-30-1). A. Terminal whorls of branchlets of mature plant, X 7.5. B. Node of main axis showing details of stipulodes, X 20. C. Mature oogonium with coronula; also showing outline of mature oospore, X 66. D. Terminal segment of mature branchlet, $X$ 66. B. Branchlet node displaying young gametangia, X 66 . 

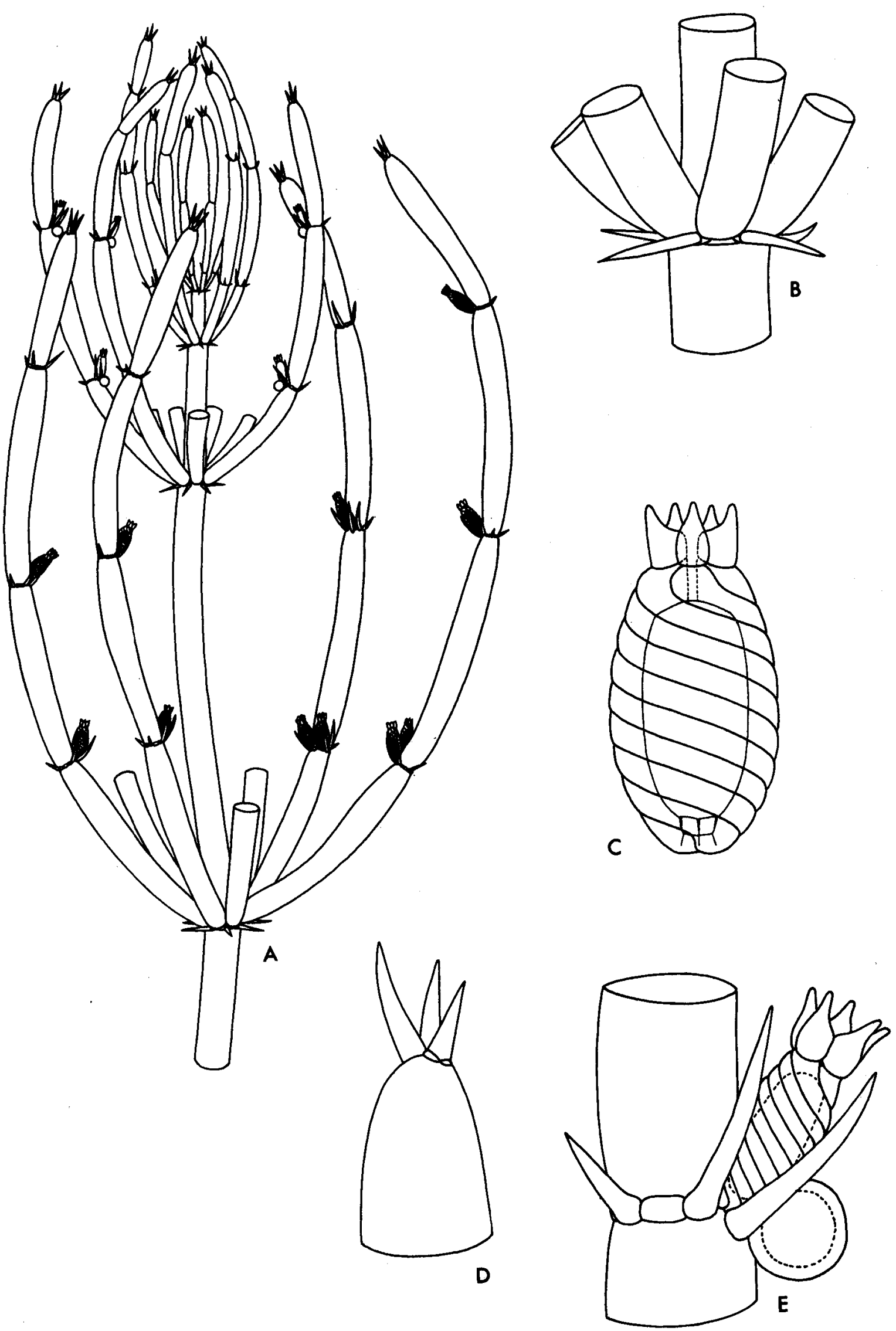
Fig. 30. Chara braunii f. schweinitzij $(64-9-7-2)$. A. Terminal whorls of branchlets of mature plant, X 7.5. B. Mature oogonium with coronula; also showing outline of mature oospore, X 66. 


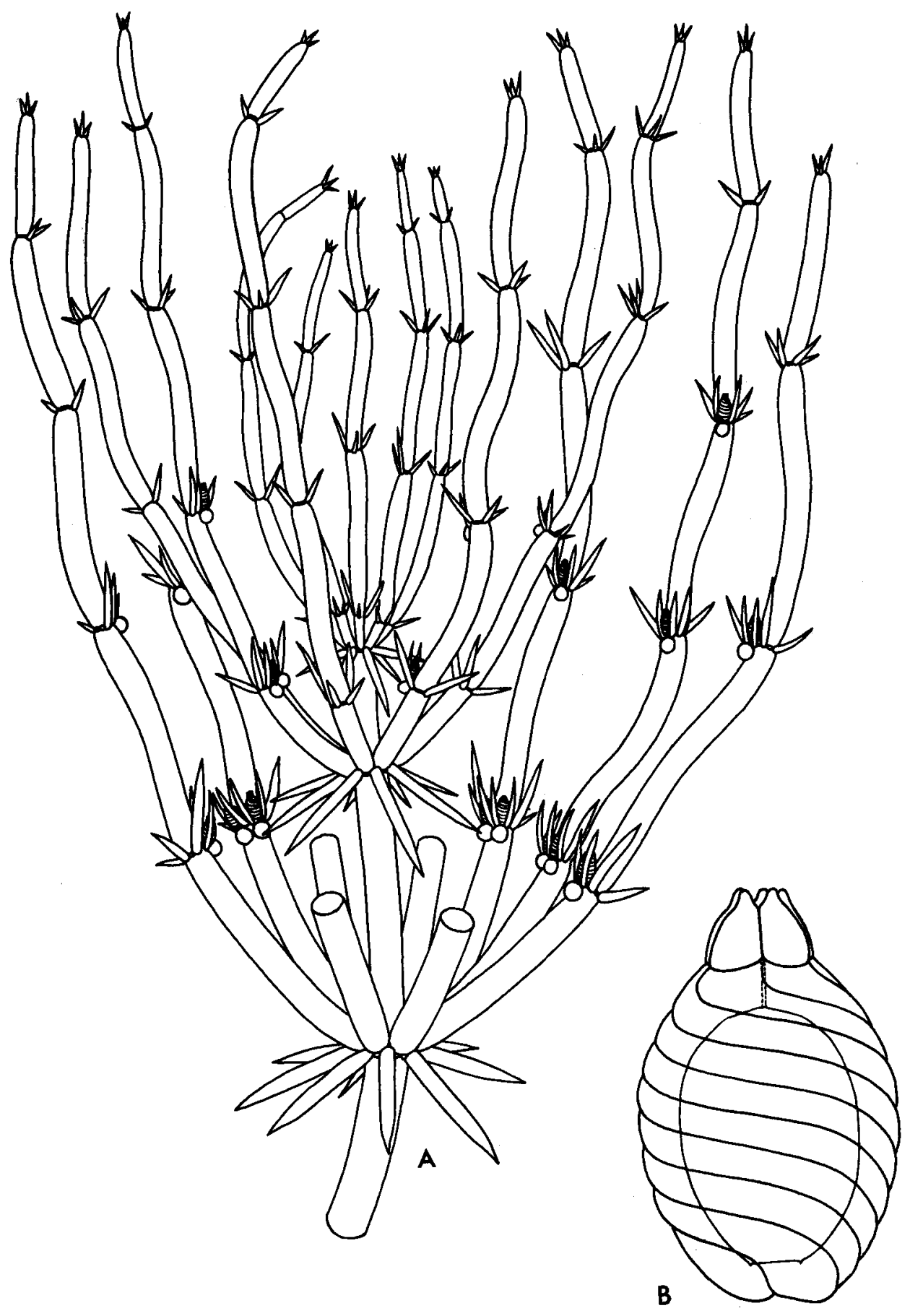


to black, usually glossy, never incrusted with lime, 420-600 $\mu$ long, 200-405 $\mu$ wide; striae of 7-10 ridges; D.E.A. $45-85 \mu$; membrane smooth or slightly roughened. Antheridia solitary or geminate, 262-390 $\mu$ in diameter, 8-scutate. SPEC IMENS EXAMINED: TEXAS: (61-4-1-4) San Marcos Spring, just below main source, in quiet water near bank, E San Marcos, Hays Co., Texas, D. Tindall and W. Minckley, April 1, 1961. (63-2-1-1) San Marcos River, in current near public swimming area, San Marcos, Hays Co., Texas, D. TindaII and A. Hotchkiss, Feb. I, 1963.

NEN MRXICO: (64-9-9-3) Roberts Lake (large reservoir) 25 mi. NNE Silver City, State Hwy 25, Grant Co., New Mexico, D. Tindall and A. Hotchkiss, Sept. 9, 1964.

ARIZONA: (WM 927) Arizona, Santa Cruz Co., spring in Sycamore Canyon, $14 \mathrm{mi}$. W, $1 \mathrm{mi}$. N Nogales, W. Minckley, May 2, 1964 (same locality as $64-9-1-5)$. (64-9-1-5) Small concrete tank (spring-fed), 1 mi. N Sycamore Canyon picnic area, Coronado National Forest, Santa Cruz Co., Arizona, D. Tindall, A. Hotchkiss, and W. Minckley, Sept. 1, 1964. (648-30-1) Large spring-fed lake, I mi. B Vernon intersection on U.S. Hwy. 60, Apache Co., Arizona, D. Tindall and A. Hotchkiss, Aug. 30, 1964. (64-9-7-2) Two small earthen tanks on $E$ side of State Fwy. 79, just $S$ Schnebly Hill Road intersection (ca. $15 \mathrm{mi}$. S Flagstaff), Coconino Co., Arizona, D. Tindall and A. Hotchkiss, Sept. 7, 1964.

SAN LUIS POTOSI: (Schaffner, no number) "Flora Mexicana, San Iuis Potosi", Mexico, J. C. Schaffner, 1879 (NY); det. as Chara coronata by T. F. Allen, annotated as $\underline{\text {. }}$ braunii $f$. pallida by R. Wood, (Pringle, IV) "shallow ponds, San Iuis Potosi", Mexico, G. Pringle, Sept. 28, 1890 (NY), det. as Chara coronata by T. F. Allen, annotated as $\underline{C}$. braunii f. pallida by $R$. Wood. 
Mex. Hwy 40, Durango, Mexico, D. and Patricia Tindall, Aug. 8, 1963. (63-8-8-4) Quarry pond, 2.6 mi W Rio Chico, Mex. Hwy 40, Durango, Mexico, D. and Patricia Tindall, Aug. 8, 1963. (63-8-9-2) Stream, in quiet water below large reservoir, $21 \mathrm{mi}$. N. Durango, Mex. Hwy 45, Durango, Mexico, D. and Patricia Tindall, Aug. 9, 1963.

TYPE LOCALITY: Germany (Gmelin, 1826).

DISTRIBUTION: Chara braunii is one of the most ubiquitous species of Characeae. The species occurs to some extent on every major continent (Wood and Imahori, 1959). The known distribution of the species in North America includes Quebec, Vermont, New York, Massachusetts, Connecticut, Pennsylvania, North Carolina, Florida, Ohio, Indiana, Wisconsin, Minnesota, Iowa, Illinois, Missouri, Nebraska, Kansas, Oklahoma, Texas, New Mexico, Arizona, Central Mexico, British Columbia, California (Braun and Nordstedt, 1882; Allen, 1882; Robinson, 1906; Prescott, 1931, 1951; Daily, 1944, 1953; Allen, 1951; Ophel, 1952; Wood, 1947; Wood and Muenscher, 1956; Hevly, 1961; Griffin, 1963), Ontario, Kentucky, and Tennessee (unpublished).

Previous records from the study area include several forma, varieties, and even species which now appear to represent a single polymorphic taxon (Wood, 1962). Braun and Nordstedt (1882) described ‥ coronata var. braunii f. novi-mexicana from New Mexico (moll. by C. Wright, no. 854 and 980). The collection data presented by Braun and Nordstedt is somewhat confusing but appears to refer to two specimens. Allen (1882) referred to a collection by Wright (no. 980) from New Mexico as $\underline{\text { C. coronata var. braunil f. tenera }}$ A. Br. Apparently forma novi-mexicana and forma tenera represent a single taxon. Allen (loc. cit.) reported a new variety, $\underline{\text { C. coronata var. gracilis }}$ from near Silver City, New Mexico (Coll. by Rusby, 1880). Robinson (1906) designated Rusby's specimen (var. gracilis Allen) as the type for a new species, ‥ pallida, and included forma novi-mexicana and forma tenera as 
synonyms. The latter author listed the species as occurring from New Mexico to Central Mexico but did not give precise localities for the Mexican records. Three specimens of $\underline{\text {. }}$ braumij from San Luis Potosi, Mexico, were examined during the present study. One specimen was collected by J. G. Schaffner (1887) and the other two were collected from a single locality, or from adjacent ones by G. Pringle (1890). These specimens were originally determined as Chara coronata by T. F. Allen but were subsequently further defined as $\underline{\text {. braunii }} f$. pallida by $R$. D. Wood. None of these collections has been quoted in the literature; however, according to annotations on the sheets they will be included in Wood's forthcoming monograph.

Other records of $\mathrm{C}$. braunii from the study area include those of Hevly (1961; ‥ braunii var. braunil, Lake Mary east of Flagstaff, Coccnino County, Arizona, Hevly \& Haskell, July 16, 1958; C. braunii var. schweinitzii, Foxboro Lake, SE of Flagstaff, Coconino County, Arizona, Hevly \& Haskell, July 5, 1958), a single collection by Ophel (1952; ‥ braunii var schweinitzii, Lake Quanah Parker, Wichita Mountains, Comanche County, Oklahoma, Oct. 1948).

The species has been observed only rarely in South America. Its known distribution is presently limited to Argentina and Chile (Horn af Rantzien, 1950). However, extensive collecting on that continent will doubtlessly reveal a much wider distribution.

The known distribution of $\mathrm{C}$. braunit in the study area is shown in Figure 31. Although the species appears to occupy a wide range within the area, it was common only in highland areas. Eodies of water examined in desert and coastal areas did not contain the species.

BCOLOGY: Physicochemical features of the habitats.-Various features of the habitats supporting Chara braunil are included in Table 21. The species was best developed and occurred in greatest abundance on sandy substrates, in relatively quiet and shallow waters. The species flourished 


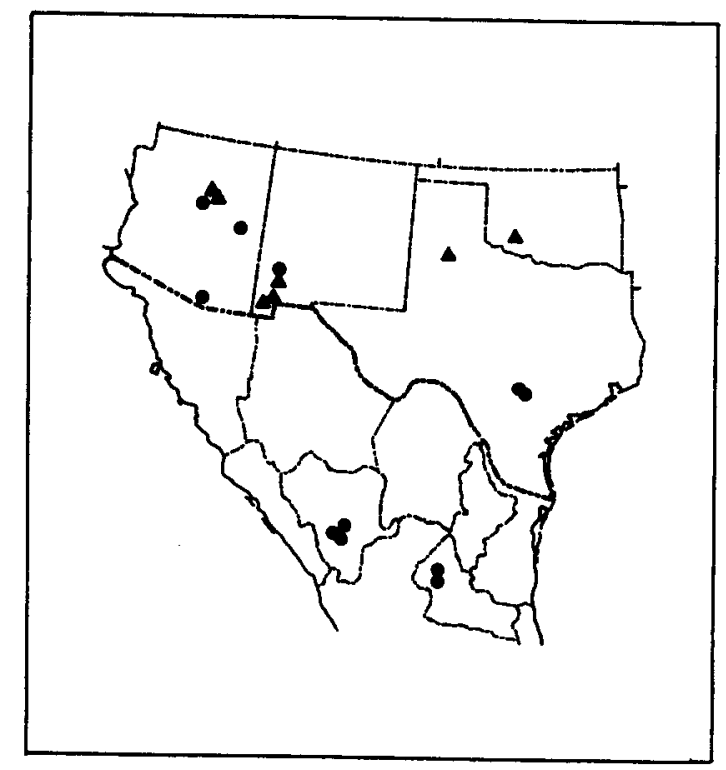

Fig. 31. Distribution of Chara braunii in the study area; localities examined during the present study, $\Delta$ localities reported in the literature. 
Table 21. Physicochemical features of the habitats supporting Chara braunif.

\begin{tabular}{|c|c|c|c|c|c|c|c|c|c|c|c|}
\hline Specimens & Locality & Habitat & Substrate & Depth & $\begin{array}{l}\text { Tur- } \\
\text { bidity }\end{array}$ & Light & $\begin{array}{l}\text { Tempe } \\
\text { air }\end{array}$ & $\begin{array}{l}\text { cature } \\
\text { water }\end{array}$ & $\mathrm{pH}$ & Alk. & $\mathrm{CO}_{2}$ \\
\hline $61-4-1-4$ & Texas & $\begin{array}{l}\text { pool and rif- } \\
\text { fle of spring } \\
\text { fed stream }\end{array}$ & $\begin{array}{l}\text { sand \& } \\
\text { organic }\end{array}$ & $\begin{array}{l}0.40- \\
0.50\end{array}$ & 0 & $\begin{array}{l}\text { open \& } \\
\text { shaded }\end{array}$ & - & $\begin{array}{l}21.6- \\
23.2\end{array}$ & $\begin{array}{l}7 \cdot 3- \\
7 \cdot 5\end{array}$ & $\begin{array}{l}270- \\
260\end{array}$ & $\begin{array}{l}26.0 \\
16.0\end{array}$ \\
\hline $64-8-30-1$ & Artzona & $\begin{array}{l}\text { spring-fed } \\
\text { lake }\end{array}$ & $\operatorname{sand-mud}$ & $\begin{array}{l}0.2- \\
1.0\end{array}$ & 0 & open & 26.0 & $\begin{array}{l}20.0- \\
23.0\end{array}$ & $\begin{array}{l}9.4- \\
10.0\end{array}$ & 102 & 0.0 \\
\hline $64-9-1-5$ & Arizona & $\begin{array}{l}\text { spring-fed } \\
\text { concrete tank }\end{array}$ & $\begin{array}{l}\text { organic- } \\
\text { silt }\end{array}$ & 0.3 & 0 & $\begin{array}{l}\text { open \& } \\
\text { shaded }\end{array}$ & 31.0 & 25.0 & 7.7 & 141 & 5.5 \\
\hline $64-9-7-2$ & Arizona & small tank & sand-mud & 1.0 & 0 & $\begin{array}{l}\text { open \& } \\
\text { shaded }\end{array}$ & 23.0 & 20.0 & 7.8 & 109 & 3.0 \\
\hline $64-9-9-3$ & Arizona & lake & $\operatorname{sand}-\operatorname{mud}$ & 0.45 & + & open & 23.0 & 21.5 & 8.4 & 140 & 0.0 \\
\hline $63-8-8-2$ & Durango & swift river & $\begin{array}{l}\text { sand- } \\
\text { gravel }\end{array}$ & $\begin{array}{l}0.10- \\
0.20\end{array}$ & 0 & open & 22.0 & 21.0 & 8.0 & 42 & 0.0 \\
\hline $63-8-8-4$ & Durango & quarry pond & $\begin{array}{l}\text { sand- } \\
\text { gravel }\end{array}$ & $\begin{array}{l}0.2- \\
0.3\end{array}$ & 0 & open & 19.0 & 22.5 & $9 \cdot 4$ & 43 & 0.0 \\
\hline $63-8-9-2$ & Durango & stream pool & silt-mud & 0.5 & $t$ & open & 23.0 & 20.0 & 7.8 & 93 & 2.5 \\
\hline
\end{tabular}


in both open and shaded areas as well as in clear or moderately turbid waters. Water temperatures measured in the habitats were quite consistent throughout the study area, ranging from 20-25 C. The single habitat with a temperature of $25 \mathrm{C}$ displayed a luxuriant stand of $\underline{\mathrm{C}}$. braunii, but a massive growth of epiphytes nearly covered the plants. Chara braunii did not appear to be affected by the extremes in pH, alkalinity, and free carbon dioxide which characterized the various habitats. The ability to withstand such extremes enables the species to survive in, or form dense beds in, rather limited bodies of water and to successfully compete with other charophytes and vascular plants.

Plant communities.--The species was collected on two occasions from a small spring fed concrete tank in Santa Cruz County, Arizona (WM 927, May 2, 1964; 64-9-1-5). On both occasions, the species was the only attached macrophyte in the tank. In May, the major epiphytes and freefloating plants associated with the Chara were Vaucheria sessilis, Microspora sp., Characeopsis sp., Rhopolodia gibba, Gomphonema sp., G. acuminatum var. coronatum, G. intricatum, Symedra sp., Epithemia sorex, Denticula sp., Cymbella minima, and Achnanthes sp. The September sample showed a marked change in associated flora. The diatoms, Rhopolodia, Epithemia, Denticula, and Symedra remained abundant. Vaucheria, Microspora, and Characeopsis had disappeared, but the blue green algae, Anabaena circinalis, Phormidium sp., Nodularia sp., Cylindrospermum sp., and Calothrix sp. had become abundant. Chara braunii was observed in two swift-current habitats. The species occurred as small isolated tufts in the San Marcos River (Hays Co., Texas, 63-2-1-1). Similar tufts of . globularis and Nitella oligospira occurred on the same riffles. Other plants in the vicinity of the charophytes included Najas guadalupensis, Zannichellia palustris, Sagittaria sp., Dichotomosiphon tuberosa, Cladophora sp., Batrachospermum sp., and Thorea 
sp. Abundant epiphytes on Chara bramii consisted primarily of species of Gomphonema and Tabellaria. A moderate current area of the Rio Chico near Durango, Mexico (63-8-8-2), supported a luxuriant stand of Nitella clavata with Chara braunii sparsely distributed throughout. Najas guadalupensis was the only vascular plant associated with the charophytes.

Shallow pool areas of streams also supported stands of $\underline{\mathrm{C}}$. braunii. This habitat varied according to the type of stream; however, plant associations were somewhat similar. The shallow shore line of the large ponded area of San Marcos Spring (61-4-1-4) supported a minimal stand of $\underline{\text {. braunii }}$ in close association with Nitella missouriensis. Other plants associated with the species were Myriophyllum spp., Ceratophyllum demersum, Cabomba caroliniana, Elodea densa, Vallisneria americana, and Ludwigia palustris. Trpha latifolia and Nasturtium officinale were present but not in close association with Chara braunii. A somewhat similar ponded area of a stream near Durango, Mexico (63-8-9-2), displayed an association of $\underline{\text {. }}$ braunii Ceratophyllum demersum, Nymphaea odorata, Myriophyllum sp., and Potamogeton sp. Chara globularis and Najas guadalupensis occurred in nearby riffles. A small amount of Chara braunii was collected from Roberts Lake (large reservoir, Grant Co., New Mexico, 64-9-9-3). Here the species occurred in association with $\underline{\mathrm{C}}$. globularis, $\underline{\mathrm{C}}$. contraria, Potamogeton sp., $\underline{\mathrm{P}}$. pectinatus, P. foliosus, Zannichellia palustris, Myriophyllum sp. Nasturtium officinale was abundant near several small springs. Hyirodictyon reticulatum and Spirogyra spp. formed extensive floating mats near the charophytes. Chara braunif was the dominant charophyte forming a distinct "chara zone" around the southern edge of a large spring-fed lake in Apache County, Arizona (64-8-30-1). The zone extended out from the bank to about $2.5 \mathrm{~m}$ and to a depth of $1 \mathrm{~m}$. Small tufts of $\underline{\mathrm{C}}$. Blobularis, Nitella clavata, and to a lesser extent N. missouriensis occurred throughout the zone. Several 
isolated stands of Potamogeton pectinatus occurred in the deeper water but only occasionally merged with the chara zone. Epiphytes on Chara braunii included Bulbochaete sp., Oedogonium sp., Cymbella sp., and Cocconeis placentula. Palmodictyon varium was very common among the charophytes. Only a single habitat did not appear to have a flowing water source. A small earthen tank in Coconino County, Arizona (64-9-7-2), displayed a mixed association of Chara braunii, ‥ globularis, Nitella missouriensis, Potamogeton foliosus, and Ranunculus aquatilis. It is interesting to note that this habitat supported the only population of Chara braunii $f$. schweinitzii that was observed in the study area.

MORPHOLOGY, CYTOLOGY, AND TAXONOMY: Considerable variation was observed among the specimens of Chara braunii from the study area. These variations are discussed below with regard to infraspecific taxa.

A chromosome number of 14 was observed in specimens from collections 61-4-1-4, 63-8-9-2, 64-8-30-1, 64-9-1-5, and 64-9-7-2. Although Chara braunii is a very variable species, it displays one of the most consistent chromosomal systems known in the Characeae. A chromosome number of 14 has also been reported for the species from Japan (Kasaki, 1960; Imahori and Kato, 1961), Indiana (Hotchkiss, 1963), and Massachusetts (Tindall and Sawa, 1964). The same number has been observed in the species from Kentucky and Tennessee (Hotchkiss, unpublished). No variation from the normal chromosome number, as has been reported for several species of Characeae, has been observed in Chara braunii.

Braun and Nordstedt (1882) and Allen (1882) were among the first workers to discuss the difficulty in distinguishing the various forms of the Chara braunii complex as separate species. Both authors concluded that separation should be limited to the variety or forma level under one species, Chara coronata. In a revision of this group, Zaneveld (1940) 
established several varieties and forma under the name $\underline{C}$. braunii which has priority over $\underline{C}$. coronata. However, Zaneveld's treatment has not proved entirely satisfactory for the North American representatives of the species (Wood, 1947, 1949; Daily, 1953; and others). In the most recent monographic treatment of the Characeae, infraspecific categories of $\underline{C}$. braunif are limited to forma of a single variety (Wood, 1962).

The study area includes type localities for forms which at one time or another were ranked as separate species, varieties, and/or forma. As mentioned above, Chara coronata var. braunii f. novi-mexicana and $\underline{C}$. coronata var. braunii f. tenera appear to represent a single taxon. Furthermore, it is quite probable that these two forma were described from specimens of the same collection (Wright, No. 980, 1851) or even from the same specimen. Allen (1882) described $\underline{\mathrm{C}}$. coronata var gracilis based on specimens collected by Rusby near Silver City, New Mexico. Robinson (1906) elevated the latter variety along with formae novi-mexica.la and tenera to the species level under the name of . . pallida. Wood (1962) included all the above-named forms under $\underline{\text { c. braunii }}$ f. pallida but more recently (Wood and Imahori, 1964) concluded that the name novi-mexicana has priority for the forma. Analyses of specimens from the study area indicate that further distinction at the forma level should be made.

In addition to forms discussed above, $\underline{c}$. braunii $f$. schweinitzii (A.Br) R.D.W. has been collected from three localities in the study area. However, the single collection examined during this study shows many characters similar to those of typical $\underline{\mathrm{C}}$. braunii.

Specimens observed from the study area form three more or less distinct categories (A, B, and C; Table 22). Previously described specimens which appear to represent similar forms are also included in the table. It is concluded that the classification of these specimens should be as follows: 
Tab1. 22. A comparison of forms of Chara braunil frow the atudy area; including specimens examined during the present atudy and those reported 1n the literature:

(A) P. novi-mexicana, (B) f. gracilis, and (C) f. Bchweinitzil.

\begin{tabular}{|c|c|c|c|c|c|c|c|c|c|c|c|c|c|c|c|c|c|c|}
\hline SPECIMENS & $\begin{array}{l}\operatorname{MaIN} A X] \\
\text { beight } \\
(\mathrm{cm})\end{array}$ & XES & $\begin{array}{l}\text { B R A } \\
\text { no. }\end{array}$ & $\begin{array}{l}\text { N } C \text { H } L \\
\text { length } \\
(\mathrm{cm})\end{array}$ & $\begin{array}{l}\text { E T S } \\
\text { no. } \\
\text { segs. }\end{array}$ & $\begin{array}{l}\text { BRACTEOLES } \\
\text { length }\end{array}$ & $\begin{array}{l}\text { STIPULODES } \\
\text { length }\end{array}$ & & $\begin{array}{l}\text { OOG O N } \\
\text { length }\end{array}$ & $\begin{array}{l}\text { N I A } \\
\text { width }\end{array}$ & $\begin{array}{l}C \circ R \circ \mathrm{N} \\
\text { height }\end{array}$ & 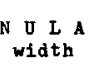 & character & $\begin{array}{l}\text { O O S P } \\
\text { length }\end{array}$ & $\begin{array}{l}O \mathrm{RES} \\
\text { width }\end{array}$ & ridges & D.E.A. & $\begin{array}{l}\text { ANTHERIDIA } \\
\text { diame ter }\end{array}$ \\
\hline WM 927 & -20 & - & $\begin{array}{l}8-10 \\
(-11) \\
\end{array}$ & -1.6 & $\begin{array}{c}(4-) \\
5\end{array}$ & -375 & -300 & $\begin{array}{l}N \\
R\end{array}$ & - & - & 一 & - & - & $\begin{array}{l}25 \\
510-600 \\
553 * 4.7 \\
\end{array}$ & $\begin{array}{l}240-315 \\
281+3.8 \\
\end{array}$ & $8-9$ & 一 & - \\
\hline $64-9-1-5$ & -35 & - & $8-9$ & -1.5 & $\begin{array}{c}(4-) \\
5\end{array}$ & -500 & -300 & $\begin{array}{l}\mathrm{N} \\
\mathrm{R} \\
\mathrm{M}\end{array}$ & - & $\longrightarrow$ & - & - & - & $\begin{array}{l}30 \\
435-570 \\
515 \pm 5.7\end{array}$ & $\begin{array}{l}200-300 \\
266 \div 3.9\end{array}$ & $8-10$ & - & - \\
\hline $64-8-30-1$ & -40 & -835 & $\begin{array}{l}(7-) \\
8-9 \\
(-10)\end{array}$ & -2.4 & $\begin{array}{l}(4-) \\
5 \\
(-6)\end{array}$ & $\begin{array}{l}315- \\
675\end{array}$ & $\begin{array}{l}225- \\
405\end{array}$ & $\begin{array}{l}-T \\
R \\
M \\
M\end{array}$ & $\begin{array}{l}16 \\
780-937 \\
861+11.7\end{array}$ & $\begin{array}{l}405-465 \\
428 \pm 4.8\end{array}$ & $\begin{array}{l}105-165 \\
149 \pm 4.1 \\
\end{array}$ & $\begin{array}{l}180-230 \\
207 * 4.0\end{array}$ & spreading & $\begin{array}{l}31 \\
420-575 \\
532+6.4\end{array}$ & $\begin{array}{l}210-350 \\
280+5.5\end{array}$ & $8-10$ & $\begin{array}{l}45-67 \\
58 \pm 2.5 \\
\end{array}$ & $\begin{array}{l}26 \\
262-335 \\
302 \pm 3.7\end{array}$ \\
\hline 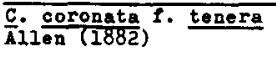 & - & - & - & - & $5-6$ & short & short & & & (2) & - & - & spreading & $420-460$ & 250 & 7 & - & - \\
\hline 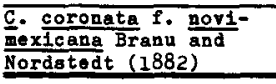 & 一 & -900 & $8-11$ & -2.0 & 一 & 一 & - & & - & - & - & $\longrightarrow$ & - & $420-480$ & - & - & - & $210-220$ \\
\hline $61-4-1-4$ & -30 & -700 & $\begin{array}{l}(8-) \\
9-10 \\
(-11) \\
\end{array}$ & -4.7 & $4-5$ & $\begin{array}{l}700- \\
825 \\
\end{array}$ & -700 & $\begin{array}{l}\mathrm{N} \\
\mathrm{R}\end{array}$ & $\begin{array}{l}10 \\
750-840 \\
789 \\
\end{array}$ & $\begin{array}{c}495-555 \\
528\end{array}$ & $\begin{array}{c}110-165 \\
136\end{array}$ & $\begin{array}{c}185-230 \\
213\end{array}$ & $\begin{array}{l}\text { spreading } \\
\text { \& tight }\end{array}$ & $\begin{array}{l}20 \\
465-510 \\
487 \pm 2.6\end{array}$ & $\begin{array}{l}330-360 \\
343 * 2.3 \\
\end{array}$ & $7-8$ & $\begin{array}{l}60-75 \\
70 \pm 1.5 \\
\end{array}$ & - \\
\hline $63-2-1-1$ & $\begin{array}{l}-10 \\
\text { tufted }\end{array}$ & -725 & $\begin{array}{c}(7-) \\
8 \\
(-9)\end{array}$ & -3.0 & $\begin{array}{l}(3-) \\
4 \\
(-5) \\
\end{array}$ & -600 & -1000 & $\begin{array}{r}\mathrm{N} \\
\mathrm{R} \\
\mathrm{M} \\
\end{array}$ & & 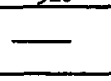 & - & - & tight & $\begin{array}{l}25 \\
450-525 \\
493+3.8 \\
\end{array}$ & $\begin{array}{r}330-380 \\
355 \pm 2.9 \\
\end{array}$ & $7-8$ & $\begin{array}{l}60-85 \\
72 \pm 1.8 \\
\end{array}$ & - \\
\hline $63-8-9-2$ & -20 & -650 & $9-10$ & -2.2 & $\begin{array}{c}(4-) \\
5 \\
\end{array}$ & $\begin{array}{l}560- \\
775 \\
\end{array}$ & $\begin{array}{l}430- \\
1376 \\
\end{array}$ & $\begin{array}{r}\mathrm{N} \\
\mathrm{R} \\
\mathrm{M} \\
\end{array}$ & $825-885$ & $540-585$ & $112-125$ & $195-215$ & tight & $\begin{array}{l}27 \\
480-585 \\
541 \pm 4.5 \\
\end{array}$ & $\begin{array}{l}315-405 \\
363 \pm 4.6 \\
\end{array}$ & $7-8$ & - & - \\
\hline $\begin{array}{l}\text { Pringle coll. } 1890 \\
\text { C. braugif } \mathrm{f} \text {. pallida } \\
\text { det. By B. D. Wood }\end{array}$ & -21 & ca.700 & $7-10$ & - & - & short & short & & - & - & - & - & spreading & $450-480$ & $300-345$ & $7-8$ & 一 & - \\
\hline $\begin{array}{l}\text { C. Cosonata var. } \\
\text { gracilis Allen (1882) }\end{array}$ & -20 & - & $9-10$ & - & $\begin{array}{c}(3-) \\
4\end{array}$ & short & short & & - & - & - & - & - & $480-520$ & - & $5-6$ & - & - \\
\hline $\begin{array}{l}\text { c. pallida Type des- } \\
\text { cription, Robinson } \\
(1906)\end{array}$ & -20 & $\begin{array}{l}600- \\
1000\end{array}$ & $7-10$ & -2.5 & $4-6$ & $\begin{array}{l}300- \\
900\end{array}$ & $\begin{array}{l}210- \\
750 \\
\end{array}$ & & $700-1000$ & $400-480$ & $120-210$ & $200-250$ & - & $420-520$ & $310-350$ & $5-7$ & - & $260-320$ \\
\hline $\begin{array}{l}\text { C. pelilida HoLOTYPE } \\
\text { Wood and Imahori } \\
(1964)\end{array}$ & -25 & -1000 & $6-8$ & -4.0 & $4-5$ & -450 & $\begin{array}{l}550- \\
750\end{array}$ & & - & - & - & 一 & - & $510-540$ & $360-390$ & $6-7$ & 75 & $255-300$ \\
\hline $64-9-7-1$ & -45 & -690 & $8-10$ & -3.0 & $\begin{array}{l}(4-) \\
5 \\
(-6)\end{array}$ & -1290 & -2580 & $\begin{array}{l}\bar{N} \\
\mathrm{R} \\
\mathrm{M}\end{array}$ & $\begin{array}{l}12 \\
825-900 \\
859 \pm 7.0 \\
\end{array}$ & $\begin{array}{r}510-570 \\
542+5.8 \\
\end{array}$ & $\begin{array}{l}110-165 \\
135 * 4.9 \\
\end{array}$ & $\begin{array}{l}200-240 \\
223 * 3.4 \\
\end{array}$ & tight & $\begin{array}{l}25 \\
510-555 \\
531 \pm 2.8 \\
\end{array}$ & $\begin{array}{l}335-390 \\
367 \pm 3.3 \\
\end{array}$ & $8-9$ & - & $\begin{array}{l}30 \\
330-390 \\
360 \pm 3.1 \\
\end{array}$ \\
\hline C. Schwoinitzil & -150 & -1300 & $8-11$ & -5.0 & $5-7$ & -2500 & -3500 & & $800-920$ & $490-530$ & $150-180$ & - & - & $520-650$ & $330-400$ & $9-11$ & - & $280-320$ \\
\hline
\end{tabular}


(A) Chara braunii f. novi-mexicana (A. Br.) Wood. I

C. coronata var. braunii f. novi-mexicana A. Br.

C. coronata var. braunii f. tenera $\mathrm{A} . \mathrm{Br}$.

This forma is characterized by short bracteoles and stipulodes, narrow oospores with 8-10 closely arranged ridges and widely spreading crown-cells on the oogonia (Fig. 29, Table 22A).

(B) Chara braunii f. gracilis (T.F.A.) comb. nov.

C. coronata var. gracilis T.F.A.

C. pallida Robinson

This more or less intermediate forma is characterized by bracteoles and stipulodes of medium length, relatively wide oospores with 7-8 widely separated ridges, and tight to somewhat spreading crown-cells on the oogonia (Table 22B).

(C) Chara bramii f. schweinitzii (A. Br.) Wood.

C. coronata subsp. schweinitzii A. Br.

C. schweinitzii (A. Br.) Kutz.

C. braunii var. schweinitzii (A. Br.) Zanev.

This forma is characterized by very long and well-developed anterior bract cells and stipulodes, relatively wide oospores with 8-9 ridges, and rather tight crown cells on the oogonia (Fig. 30, Table 22C).

1. Does not include the description of the holotype of Chara pallida presented by Wood and Imahori (1964) under the name $\underline{\text { C. braunii f. }}$ novi-mexicana. 
CHARA HYDROPITYS Reichenbach

Figure 32

Chara hydropitys Reichenbach in Mössler (1829:1600).

C. robbinsii Halsted (1879:183).

C. schneckii Robinson (1906:271).

C. mexicana (T.F.A.) Robinson (1906:274).

C. Iiebmannii Robinson (1906:274).

C. fibrosa Ag. ex Bruz. var. hydropitys (Reich.) Wood (1962:14).

LITERATURE FOR THE STUDY AREA: Braun and Nordstedt (1882), Allen (1888, 1893), Robinson (1906), Zaneveld (1940), Horn af Rantzien (1950), and Griffin (1963). See also Wallman (1853), Braun (1859), Groves and Groves (1911), Daily (1953, 1958), and Wood and Muenscher (1956).

DESCRIPTION OF SPBCIMENS (including 10 specimens from collection 61-9-3-1): Plants monoecious, to $38 \mathrm{~cm}$ high, appearing very lax, feathery, and rather delicate but actually quite sturdy, yellow-green to dark green, not incrusted with lime. Main axes 500-600 $\mu$ in diameter; cortex basically diplostichous but frequently appearing triplostichous, primary and secondary rows about equal or displaying slightly tylacanthous condition; spine cells well developed on upper internodes but deciduous on older ones, $430-1160 \mu$ long, narrow and acuminate. Stipulodes haplostephanous, twice as numerous as branchlets, 860-2150 $\mu$ long, narrow and acuminate. Branchlets spreading, straight or slightly curved, (12-) $13(-14)$ in a whorl, $1.0-1.9 \mathrm{~cm}$ long, narrowing considerably toward distal end, $1 / 3-1 / 2 \mathrm{X}$ internode length on older parts of plants but usually much longer than internode on younger parts of plants; consisting of (6-) $7(-8)$ segments of which the basal one is always uncorticate, the next (1-) $2(-3)$ are corticated, the remaining distal ones are uncorticated. Bract cells verticillate, well developed at all branchlet nodes, posteriors and anteriors identical, numbering 7-8 
Fig. 32. Chara hydropitys (61-9-3-1). A. Whorl of mature branchlets, X 10. B. Mature oogonium with coronula; also showing outline of mature oospore, X 66. C. Habit sketch of mature plant, X 1/2. 


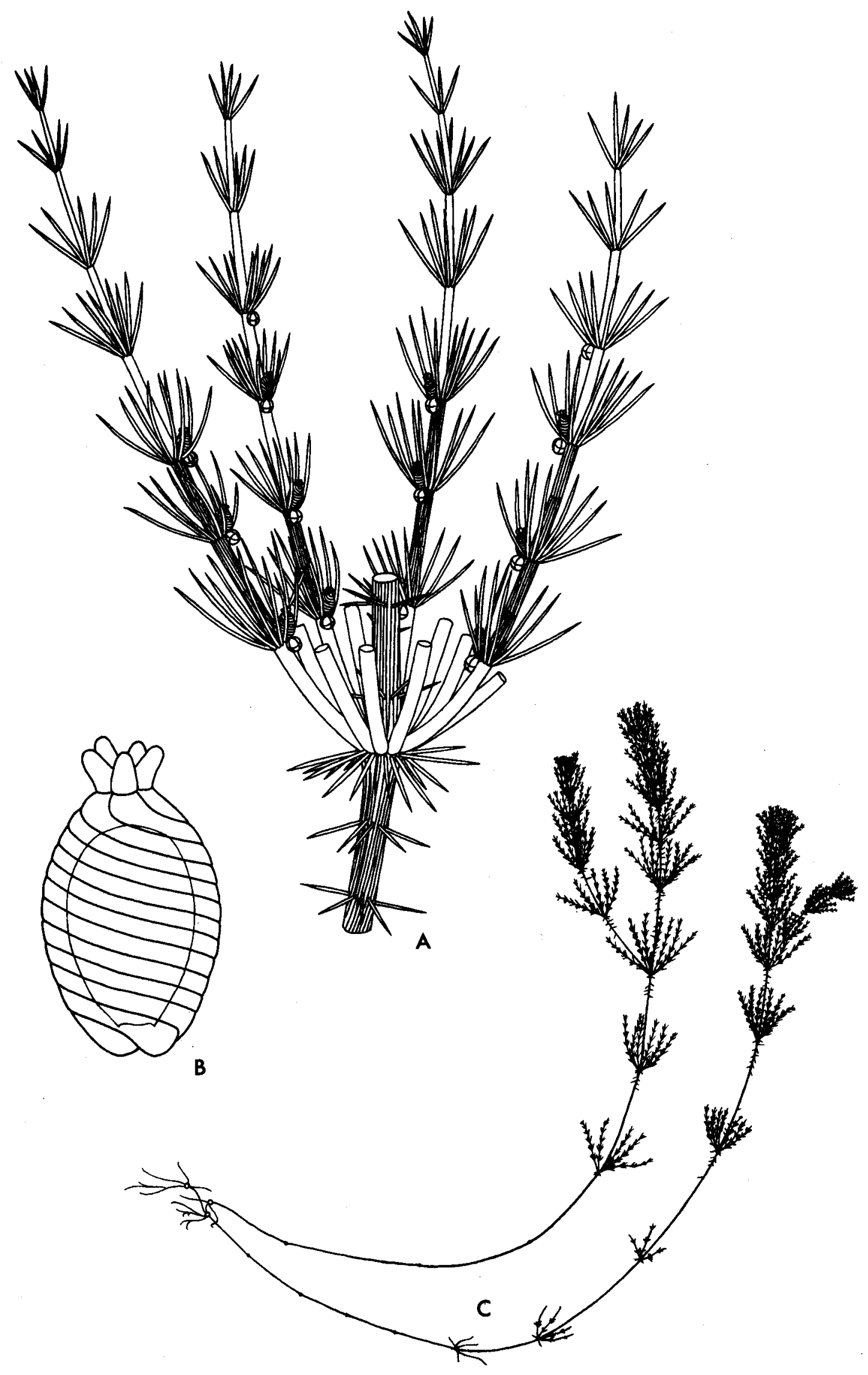


at first node, 860-2795 $\mu$ long, narrow and acuminate. Bracteoles 2, similar to, but shorter than, bract cells. Gametangia conjoined at first 3-4 branchlet nodes. Oogonia ( $N=15)$ solitary, (710-) $747 \pm 7.7(-795) \mu$ long, (374-) $416 \pm 7.9$ (-470) $\mu$ wide; coronulae spreading, (105-) $116 \pm 2.5$ $(-135) \mu$ high, (150-) $157 \pm 2.1(-165) \mu$ wide. Oospores ( $N=30)$ dark brown to black, (450-) $485 \pm 3.3(-540) \mu$ long, (270-) $302 \pm 3.6(-335) \mu$ wide; striae of (11-) $12(-13)$ ridges; D.E.A. (32-) $38 \pm 0.6(-43) \mu$; membrane very dark and opaque, covered with closely arranged papillae, ca. $1 \mu$ in diameter at base and $1-2 \frac{1}{2} \mu$ high, evenly distributed across fossa. Antheridia $(N=30)$ solitary, (270-) $289-2.0(-300) \mathrm{u}$ in diameter, 8-scutate. SPEC IMENS EXAMINED: MICHIGAN: $(64-7-23-2)$ In shallow water and emersed on saturated peat of boggy area at edge of Fish Lake, Barry Co., Michigan, A. Hotchkiss, D. Tindall, and T. Sawa, July 23, 1964.

INDIANA: (6I-8-20-4) In shallow water and on saturated mud at edge of Starve Hollow Lake, near Valonia, Jackson Co., Indiana, A. Hotchkiss and D. Tindall, Aug. 20, 1961.

MISSOURI: (62-8-6-1) Pond in woods, $1 \mathrm{mi}$. E Doniphan, U.S. Hwy 160, Ripley Co., Missouri, A. Hotchkiss and R. Prins, Aug. 6, 1962. ARKANSAS: (62-8-6-2) Pond, in town of Camp, Fuzton Co., Arkansas, A. Hotchkiss and R. Prins, Aug. 6, 1962. (62-8-6-4) Pond, 5 mi. N Camp, E side of State Hwy 9, Fulton Co., Arkansas, Aug. 6, 1962.

TEXAS: (61-9-3-1) Shallow roadside ditch, $3 \mathrm{mi}$. N Cleveland, U.S. Hwy 59, Liberty Co., Texas, D. Tindall, A. Hotchkiss, and R. Goodyear, Sept. 3, 1961.

TYPE LOCALITY: Dutch Guiana (Reichenbach in Mossler, 1829). DISTRIBUTION: Before proceeding further, it is necessary to briefly summarize some of the past and present taxonomic treatments of Chara hydropitys. Braun and Nordstedt (1882) proposed several varieties for 
the species. Robinson (1906) elevated some of the varieties to specific level and described several new species from similar material collected in North America. Zaneveld (1940) reestablished the original varietal classification and considered many of Robinson's species to be synonymous with some of the previously described varieties. Wood (1962) concluded that all

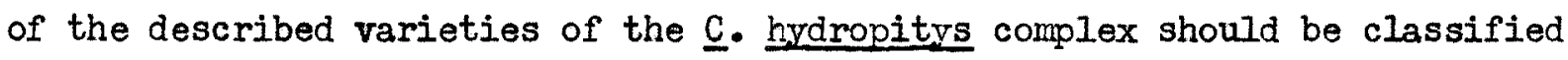
as a single variety of $\underline{\mathrm{C}}$. fibrosa. For the present, the discussion will be limited to the $\underline{C}$. hydropitys complex.

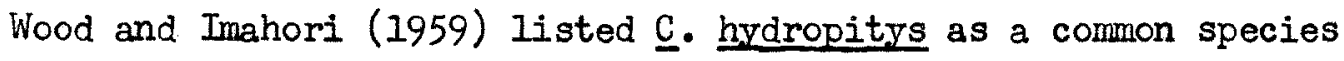
occurring in Africa, Asia, North America, and South America. A review of the literature on the species does suggest a rather wide distribution but does not indicate a common occurrence in any particular area. The following list of localities includes all known records of the species and its synonyms for North, Central, and South America: NEW YORK: Chara

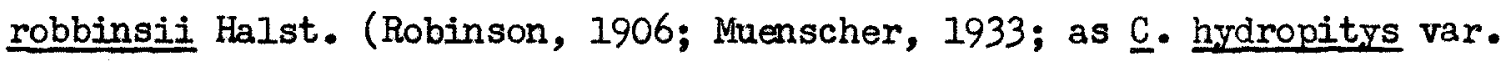
septentrionalis Nordst. ex T.F.A. Wood and Muenscher, 1956; both $=\underline{\text { C. }}$ hydropitys var. majuscula Nordst. Zaneveld, 1940). RHODE ISLAND and

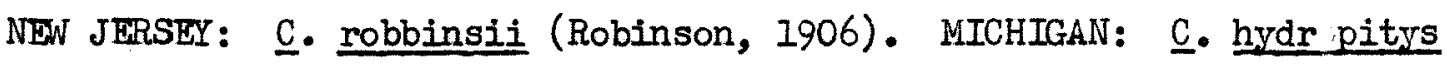
(present study). INDIANA: ‥ hydropitys var. septentrionalis (Daily, 1953; present study). ILLINOIS: $\underline{\text { C. robbinsii }}$ and $\underline{\mathrm{C}}$. schneckii Robinson (1906; both $=\underline{C}$. hydropitys var. majuscula Zaneveld, 1940). MISSOURI and

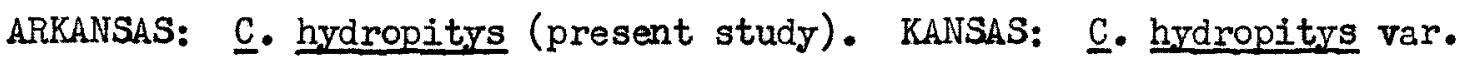
septentrionalis (Daily, 1958). TEXAS: C. hydropitys (Griffin, 1963; present study). "NORTH MEXICO": C. hydropitys var. mexicana Allen (1893; as C.. mexicana Robinson, 1906; both $=\underline{\mathrm{C}}$. hydropitys var. majuscula Zaneveld, 1940). "NEAR MIRADOR," MEXICO: c. hydropitys var. perfecta $\mathrm{A} . \mathrm{Br}$. (Braun and Nordstedt, 1882; as C. 1iebmannii Robinson, 1906). VERA CRUZ: C. hydropitys var. majuscula (Braun and Nordstedt, 1882). CHIAPAS: C. hydropitys (Griffin, 
1963). GUATEMALA: ‥ mexicana (Robinson, 1906). DUTCH GUTANA: C. hydropitys, TYPE (Reichenbach in Mossler, 1829; as var. genuina Braun, 1859). FRENCH GUIANA: C. hydropitys (Wallman, 1859). BRAZIL: $\underline{\text { C. hydropitys var. genuina }}$ (Braun, 1859), var. perfecta, and var. brachvpitys A. Br. (Braun and Nordstedt, 1882). CUBA: ‥ hydropitys (Groves and Groves, 1911).

The distribution of Chara hydropitys in the study area is shown in Figure 33. The Mexican records of the species listed by Allen (1893) and Braun and Nordstedt (1882) are not included because the precise localities are unknown.

As is presently known, Chara hydropitys is more or less limited to a unique geographical range on the continents discussed above; occupying lowland areas extending from midwestern United States south through eastern Mexico, Central America, Guiana, and into Brazil. It is interesting that the distribution of the species follows the same general pattern as the Mississippi flyway which is periodically transversed by numerous species of migratory waterfowl. The occurrence of $\underline{c}$. hydropitys in the West Indies and in northeastern United States may be only an extension of the above range. However, if there is a true correlation between migration routes and the distribution of the species, the latter may represent the route extending from northeastern United States south along the east coast through the West Indies and into northern South America.

One other species described by Robinson (1906), Chara keukensis (C. gymopitys var. keukensis Allen), shows marked similarities to $\underline{\mathrm{C}}$. hydropitys. The known geographical range of $\underline{\mathrm{C}}$. keukensis overlaps the northern limits of the $\underline{\mathrm{C}}$. hydropitys range; being found in New York, Ontario, Indiana, and southern Illinois (Robinson, 1906; Daily, 1953; Wood and Muenscher, 1956). 


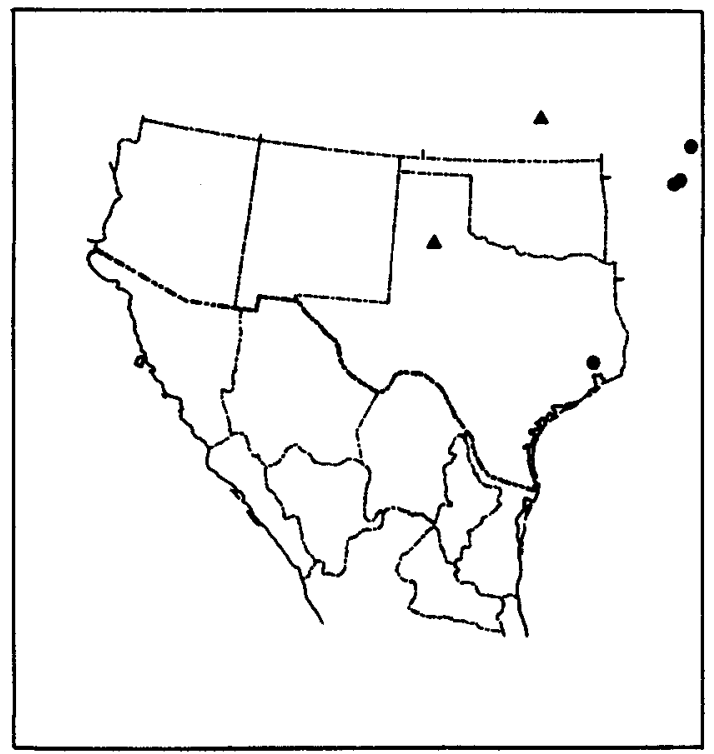

Fig. 33. Distribution of Chara hydropitys in the study area; localities examined during the present study, $\Delta$ localities reported in the Iiterature. 
was collected from two general types of habitat. Each type supported a particular growth form of the species. The single population examined in the study area (Iiberty Co., Texas) and the plants from the Arkansas and Missouri localities occurred as luxuriant stands completely submerged at depths up to $1 \mathrm{~m}$ in relatively small bodies of water. In contrast, the populations observed in Indiana and Michigan occurred as small isolated tufts emersed on saturated soil or submerged in $3-5 \mathrm{~cm}$ of water along edges of rather large lakes (Table 23).

The substrates of the habitats varied considerably, ranging from a silt-sand composition to nearly pure peat (Table 23). In general the various substrates appeared quite rich and all of them supported welldeveloped plants. Water level appeared to be the only direct growth deterrent factor.

Water temperature appears to be an important factor with regard to the distribution of the species. Daily (1958) regarded the shallow waters supporting $\underline{\mathrm{C}}$. hydropitys in Indiana as being conducive to greater light penetration and warmer conditions for which the species appeared to be particularly adapted. My observations on such habitats in Indiana and Michigan, as well as those made on the deeper but wamer southem habitats, support this generalization. Terperatures of the waters in the Arkansas and Missouri localities (22 and $23.5 \mathrm{C}$, respectively, Table 23) were recorded at a time when the species was not present. The absence of the species in the Arkansas locality in April 1962 and its presence in August of that year indicates a seasonal occurrence that is correlative with warmer temperatures.

Since data on the chemical nature of the waters supporting $\underline{C}$. hydropitys are not in the literature, only gross generalities can be made as to the types of water which may be most suitable for the species. The 
Table 23. Physicochemical features of habitats supporting Chara hydropitys.

\begin{tabular}{|c|c|c|c|c|c|c|c|c|c|c|c|}
\hline Specimens & Locality & Habitat & Substrate & Depth & $\begin{array}{l}\text { Tur- } \\
\text { bidity }\end{array}$ & Iight & $\begin{array}{l}\text { Tempe } \\
\text { air }\end{array}$ & $\begin{array}{l}\text { ature } \\
\text { water }\end{array}$ & $\mathrm{pH}$ & Alk. & $\mathrm{CO}_{2}$ \\
\hline $64-7-23-2$ & Michigan & $\begin{array}{l}\text { shallow edge } \\
\text { of lake }\end{array}$ & peat & -0.05 & 0 & shaded & 29.7 & 25.5 & 7.5 & 185 & 10.1 \\
\hline $61-8-20-4$ & Indiana & $\begin{array}{l}\text { shallow edge } \\
\text { of lake }\end{array}$ & sand-silt & -0.03 & 0 & open & 21.0 & 26.0 & 8.8 & 43.8 & 0.0 \\
\hline $62-8-6-1$ & Missouri & pond & mud-sand & $\begin{array}{l}0.20- \\
1.0\end{array}$ & + & $\begin{array}{l}\text { open \& } \\
\text { shaded }\end{array}$ & 26.0 & 23.5 & 7.6 & 49 & 2.0 \\
\hline $62-8-6-2$ & Arkansas & pond & silt-mud & $\begin{array}{l}0.30 \\
1.0\end{array}$ & 0 & open & 27.0 & 22.0 & 8.0 & 189 & 3.0 \\
\hline $61-9-3-1$ & Texas & ditch & $\begin{array}{l}\text { silt- } \\
\text { organic }\end{array}$ & $\begin{array}{l}0.30- \\
0.8\end{array}$ & 0 & open & 31.0 & 31.0 & 7.8 & 40 & 1.5 \\
\hline
\end{tabular}


limited data collected during the present study show a general trend toward nonturbid waters with a moderately alkaline pH, a low to medium alkalinity, and a low chloride content (Table 23). The species was also found to be tolerant to a complete lack of free carbon dioxide.

The general ecology and known distribution of $\underline{\mathrm{c}}$. hydropitys suggest that it is of tropical origin and that it invades more northern areas when dispersal mechanisms are available anc when habitat conditions are suitable. Plant communities.--Other macrophytes were not directly associated

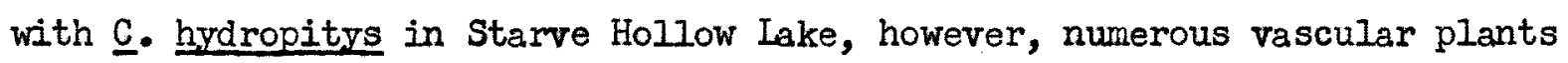
occupied the deeper areas of the lake. Plants directly associated with the species in Fish Lake included the green alga Dichotomosiphon tuberosa and the emergent vascular plant Sagittaria latifolia. Chara hydropitys appeared to be in danger of being smothered by the latter species. Fish Lake is a rather large but shallow, spring-fed larl lake confronted at one edge by a large sand dune. The renainder of the lake shore is characterized by various soil types. The main body of the lake is uniform in character but the numerous marshy areas around the lake vary considerably in physical and chemical character. Chara hydropitys occurred in such an area characterized by a peat substrate, whereas, $\underline{\mathrm{C}}$. braunii occurred in a shallow slough on a sandy substrate. Small beds of very compact $\underline{\mathrm{C}}$. vulgaris and very sparse tufts of $\underline{\text {. }}$ zeylanica and Nitella tenuissima as well as numerous vascular plants occurred on the marl substrate in the main body of the lake.

There are no records of vascular plants from the Arkansas and Missouri localities when $\underline{C}$. hydropitys was collected. The pond in Camp, Arkansas supported a luxuriant stand of Tolypella sp. in April 1962, but Chara hydropitys was the only charophyte in the habitat in August of that year. The Missouri locality was examined about two years (Sept. 13, 1964) 
after the original collection of $\underline{\mathrm{C}}$. hydropitys was made. Chara hydropitys was not present, but Potamogeton $\mathrm{sp}$. and other vascular plants completely dominated the habitat. This along with observations in other areas suggest that Chara hydropitys may be an early colonizing species which rapidly gives way to the next level in plant succession.

Chara sejuncta occurred as isolated plants sparsely distributed throughout the stand of $\underline{\mathrm{C}}$. hydropitys in the Texas locality. No vascular plants were observed in direct association with the charophytes. A massive epiphytic flora occurred on the charophytes in this locality. The more conmon epiphytes included species of Bulbochaete, Oedogonium, Cymbella, Gomphonema, and Imgbya. Various species of Cosmarium also were common in the habitat.

MORPHOLOGY, CYTOLOGY, AND TAXONOMY: Only specinens from the Texas locality were examined in detail (see description). However, some gross variations were observed between plants from different localities. Specimens from Michigan and Indiana were small and compact, whereas, the specimens from Missouri, Arkansas, and Texas were elongate. The various habits resulted from the type of habitat which the species occupied. When placed in soilwater culture, plants from northern localities grew to a size comparable to that of plants from southern localities. More significant variations were noted in branchlet segment number and cortication. Specimens from Michigan were characterized by 4-5 branchlet segments of which the second one was very rarely corticated. The Indiana specimens displayed 5-6 segments of which the second one was usually corticated. Plants from Missouri and Arkansas were quite similar to those of the Texas locality. Their branchlets were characterized by $6-8$ segments of which $1-3$ (usually 2) were regularly corticated.

One very consistent feature of specimens from all localities was that 
of chromosome number. Counts made by A. T. Hotchkiss revealed $\mathbb{1}_{4}$ chromosornes, exclusively.

The separation of $\underline{\mathrm{C}}$ hydropitys into varieties by Braun and Nordstedt (1882) and its further separation into several species by Robinson (1906) illustrates the marked variation that occurs in the species complex. The observations made during the present study support the maintenance of but a single species. It also is evident that $\underline{\underline{C}}$. hydropitys intergrades with forms such as $\underline{\text { C. keukensis }}$ (T.F.A.) Rob. which is separated from the former species by its complete lack of branchlet cortication. A more selective sampling of the Michigan locality could have revealed a form referable to c. keukensis. This intergradation may be construed as being indicative of a complete merger of $\underline{\mathrm{C}}$. hydropitys and $\underline{\mathrm{C}}$. fibrosa as concluded by Wood (1962). An inclusion of $\underline{\mathrm{C}}$. keukensis in the $\underline{\mathrm{C}}$. hrdropitys complex would be a logical approach to the problem. However, I am not presently convinced that $\underline{\mathrm{C}}$. fibrosa and $\underline{\mathrm{c}}$. hydropitys consitute but a single species, especially if the latter form is to be regarded only as a variety.

Certain specimens collected in North America do appear to represent the Chara fibrosa complex (C. fibrosa f. curtissi (Rob.) Wood). The known disbribution of this form is limited to freshwater localities on the southeastern coast of the United States. It was first observed in Volusia County, Florida, by A. H. Curtiss, May 25, 1879 (Robinson, 1906). A. T. Hotchkiss, T. Sawa, and I collected specimens referable to this species in June and October 1961 from two localities near Kitty Hawk, North Carolina. These plants are easily separated from $\underline{C}$. hydropitys both morphologically and cytologically. The plants from North Carolina display 42 chromosomes exclusively, whereas $\underline{C}$. hydropitys has only 14 .

Chara curtissii Robinson (1906) was first identified by Allen (1888)

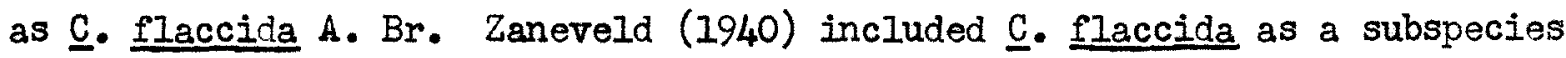


of $\underline{\underline{C}}$. fibrosa and hesitantly included $\underline{\mathrm{C}}$. curtissii as its synonym. Zaneveld (1942) recorded "immature specimens" of $\underline{C}$. fibrosa ssp. flaccida from Dutch Guiana, thus bringing together the geographical ranges of that species and $\underline{\mathrm{C}}$. hydropitys. However, comparisons of various descriptions of $\underline{\mathrm{C}}$. curtissii and $\underline{\mathrm{C}}$. flaccida do not support a complete synonymy. Moreover, C. flaccida shows greater similarity to $\underline{\mathrm{C}}$. keukensis and possibly $\underline{\mathrm{C}}$. hydropitys than it does to typical $\underline{\mathrm{C}}$. fijrosa or $\underline{\mathrm{C}}$. fibrosa $f$. curtissii

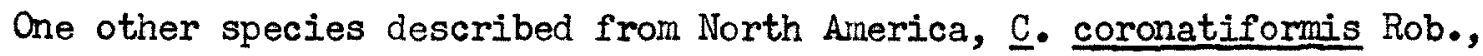
also is referable to the $\underline{\text {. fibrosa }}$ complex (Wood, 1962). According to Wood this plant represents a morphological form similar to that of the type specimen of $\underline{C}$. fibrosa. It also is nearly identical to the plants collected in North Carolina (f. curtissif). The actual locality of $\underline{\text {. coronatiformis }}$ is somewhat doubtful, but Robinson believed it to be from southern Michigan (Van Buren County). If that form of $\underline{\mathrm{C}}$. fibrosa is from southern Michigan, it constitutes the only good record of the species occurring in the same geographical range as $\underline{\mathrm{C}}$. hydropitys. 
Figure 34

Chara hormemannii Wallman $(1853: 60)$.

C. hormemannii var. nordhoffiae Allen (1900:299).

C. nordhoffiae (Allen) Robinson (1906:277).

C. hornemannii f. nordhoffiae (Allen) Wood (1962:14).

LITERATURE FOR THE STUDY AREA: Braun and Nordstedt (1882), Allen (1900), Robinson (1906), Proctor (1961), and Wood and Imahori (1964). See also Wallman (1853), Nordstedt (1889), Groves and Groves (1911), Britton and Millspaugh (1920), and Hasslow (1940).

DESCRIPTION OF SPECIMENS (including 10 specimens each from collections $61-9-7-1,63-1-24-4$, and 64-9-10-8): Plants dioecious (male and female plants similar, $30-213 \mathrm{~cm}$ high, very spiny and somewhat brittle, medium green to reddish gray, lightly to heavily incrusted with lime. Main axes rigid, 1,250-1,600 $\mathrm{p}$ in diameter; cortex diplostichous but sometimes appearing triplostichous, distinctly tylacanthous; spine cells abundant, sometimes deciduous on older internodes, $2,000-8,000 \mu$ long, acute or acuminate. Stipulodes haplostephanous, twice as numerous as branchlets, 4,000-20,000 $\mu$ long, acute or acuminate. Branchlets rigid, straight or slightly curved, (8-) 10-12 in a whorl, $2.0-8.3 \mathrm{~cm}$ Iong, usually $1 / 2$ to over $1 \mathrm{X}$ internode length, consisting of (5-) 6-8 uncorticated segments, terminal one short and acuminate. Bract cells (not differentiable from bracteoles) verticillate, well developed at all branchlet nodes, 5-6 (excluding 1 bractlet on female plants) at fertile nodes; when sterile the number per node is as follows: (1st) 7-8, (2nd) 6-7, (3rd) 6-7, (4th) 5-6, (5th) 5-6, (ultimate) 4-5; posteriors and laterals similar, 2,000$4,225 \mu$ long, acute or acuminate; anteriors 2,000-13,500 $\mu$ long, acute or acuminate; one short bractlet below each oogonium. Large unicellular 
Fig. 34. Chara hornemannii. A. Details of stipulodes (64-9-10-8), X 5. B. Habit sketch of terminal part of main axis of a mature plant (64-9-10-8), X 1/2. C. Mature branchlet displaying an antheridium (64-9-10-8), X 5. D. Details of axial cortex and spine cells $(63-1-24-4), \times 25$. 


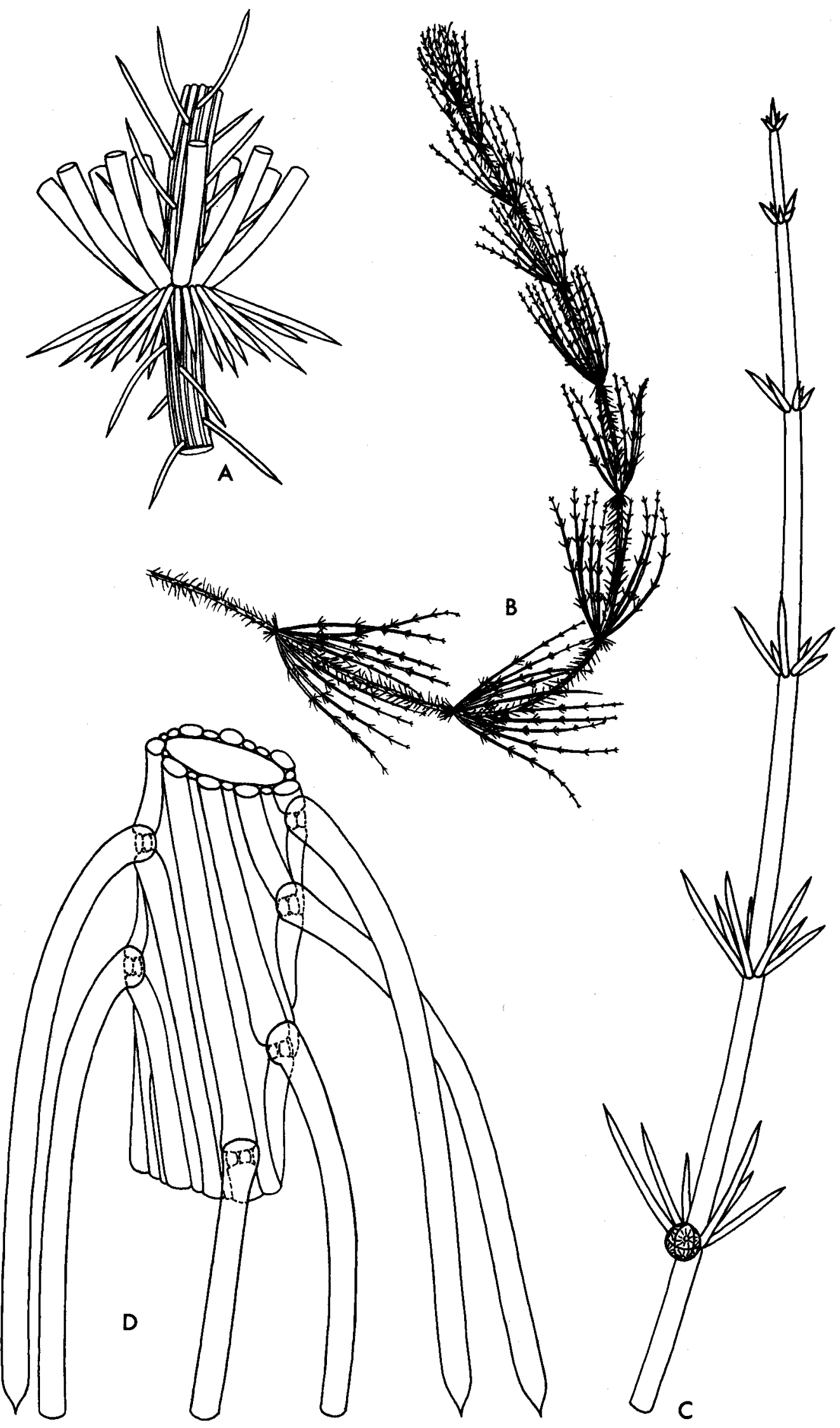


bulbils present on some specimens, 1720-2,000 $\mu$ in dianeter. Gametangia-male and female on separate plants. Oogonia solitary (rarely geminate) at first 3 branchlet nodes, 1010-1330 $\mu$ long, 555-735 $\mu$ wide; coronulae 150-225 $\mu$ high, 195-260 $\mu$ wide. Oospores dark brown to black, frequently incrusted, $585-750 \mu$ long, 350-435 $\mu$ wide; striae of 8-10 ridges; D.E.A. 6I-95 $\mu$; membrane very dark and opaque, smooth to very finely granulate (?), appearing glossy. Antheridia solitary at first 2 nodes, 945-1170 $\mu$ in diameter, 8-scutate.

SPEC IMENS EXAMINED: FIORIDA: (F46107 Univ. Fla. Herb.) Dade Co., Florida, Bay in West Lake, Everglades National Park, marl bottom, $2 \mathrm{ft}$ deep, Jan. 23, 1955, Coll. D. M. Swindle.

NEW MEXICO: (63-8-12-2) Figure Eight Lake, Bottomless Lakes State Park, E Roswell, Chaves Co., New Mexico, D. and Patricia Tindall, Aug. 12, 1963. (64-9-10-8) Locality same as above, D. Tindall and A. Hotchkiss, Sept. 10, 1964. (64-9-10-7) Earthen tank (pumped ground water E side of road to Bitter Lake, $2.5 \mathrm{mi}$. N U.S. Hwy 380, E Roswell, Chaves Co., New Mexico, D. Tindall and A. Hotchkiss, Sept. 10, 1964.

VERA CRUZ: (61-9-7-1) Large laguna, N side of Mex. Hwy 110, 2 mi. W Rio Tamesi, jus' W Tampico, Vera Cruz, Mexico, D. Tindall, A. Hotchkiss, and R. Goodyear, Sept. 7, 1961. (63-1-24-4) Shallow pool along S side of Mex. Hwy 110, 2 mi. W Rio Tamesi, just W Tampico, Vera Cruz, Mexico, D. Tindall and A. Hotchkiss, Jan. 24, 1963.

TYPE LOCALITY: Crab Island (Vieques), West Indies (Wallman, 1853). DISTRIBUTION: The literature contains a rather brief account of the distribution of Chara hornemannii. Presently, the known distribution of the species is limited to tropical and subtropical regions of North and South America, including the West Indies. The published records of the species are as follows: Florida (Allen, 1900; Robinson, 1906; H. and J. Groves, 
1911; present study); New Mexico (Braun and Nordstedt, 1882; Chaves Co., Proctor, 1961; and present study); San Diego County, California (Allen, 1900; as C. nordhoffiae Robinson, 1906); Bahama Islands (Britton and Millspaugh, 1920); Cuba (Braun and Nordstedt, 1882; H. and J. Groves, 1911); Vieques (WaIIman, 1853); Mexico (Braun and Nordstedt, 1882; Sonora or possibly Durango, Wood and Imahori, 1964; Vera Cruz, present study); Caracas, Venezuela (Allen, 1900); and Brazil (Nordstedt, 1889; Hasslow, 1940). Precise localities for the species were not included in many of the earlier works, thus an accurate interpretation of its distribution cannot be presented at this time. However, the distribution of the species in the study area, with estimates for some older localities, is included in Figure 35.

Chara hormemannii appears to be primarily a tropical or subtropical lowland species. The apparent requirement for brackish waters may, in part, account for its limited northern distribution.

ECOLOGY: Physicochemical features of the habitats.--A brief account of the physical and chemical conditions of the habitats from which Chara hornemannii was collected is included in Table 24. Data on Figure Bight Lake and the earthen tank locality near Roswell, New Mexico are supplemented by data recorded from Mirror Lake and Lake St. Francis by Hood, Mower, and Grogin (1960 vide Proctor, 1961). All of these localities apparently receive water from the Chalk Bluff Formation which discharges water characterized by high concentrations of calcium, sulfates, and chlorides (Table 24). Proctor (1961) recorded C. hornemannil from several habitats receiving water from this formation. Chloride content of the water was measured in only one of the Mexican localities but both appeared to be of similar origin. Among the chemical factors recorded $\mathrm{pH}$ showed the greatest diversity, ranging from $7.2-9.8$. The $\mathrm{pH}$ value of 9.8 and the associated low alkalinity value 


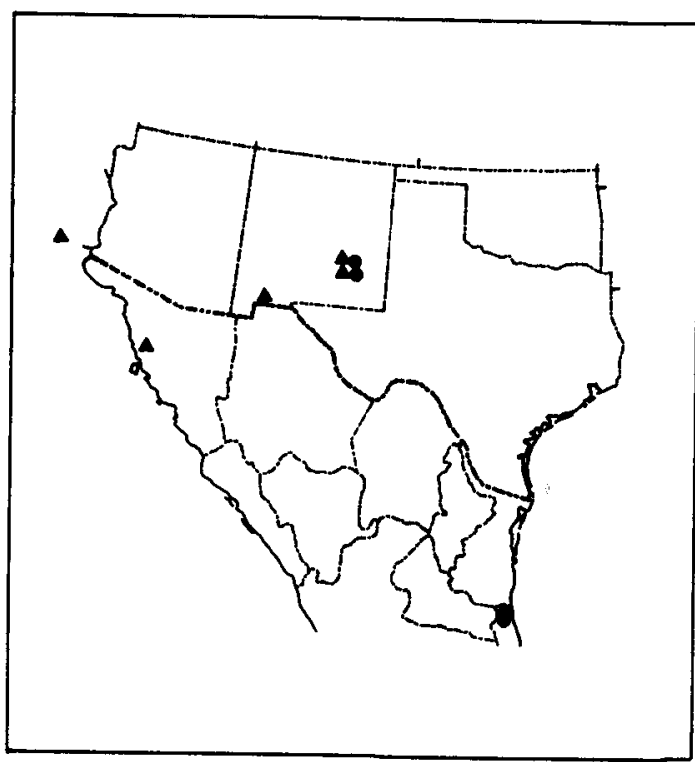

Fig. 35. Distribution of Chara hornemannii in the study area; localities examined during the present study, $\Delta$ localities reported in the Iiterature. 
Table 24. Physicochemical features of the habitats supporting Chara hornemannif. Data from Mirror Iake and Lake St. Francis (Proctor, 1961) are included as supplements to data from Figure Eight Iake. All three lakes receive water from the same formation.

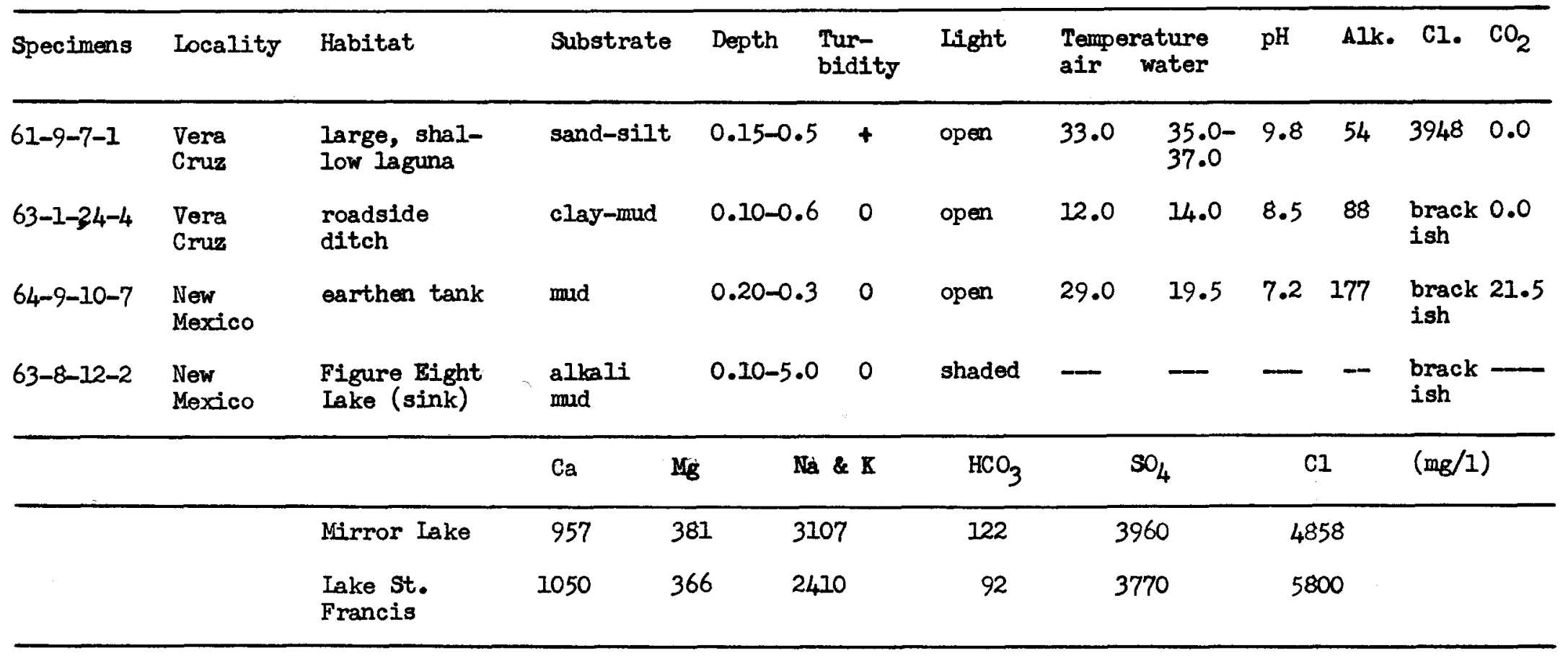


of $54 \mathrm{mg} / \mathrm{l}$ indicate that the species is capable of withstanding a conplete lack of free carbon dioxide and only minimal amounts of bicarbonate carbon dioxide.

Physical characteristics of the habitats varied considerably. This was especially evident with regard to temperature $(14.0-37.0 \mathrm{C})$ and depth $(3-6 \mathrm{~cm}$ to $5 \mathrm{~m})$ of the waters. The species showed no preference to particular light conditions, being found in well-lighted open areas as well as heavily shaded areas.

Based on the known distribution of the species in coastal areas and in inland areas characterized by brackish waters, it can be concluded that C. hornemannif is a distinctly halophytic member of the Characeae.

Although there is a definite correlation between brackish conditions and the occurrence of $\underline{\mathrm{C}}$. hormemannij, several other bodies of water similar to those discussed above were observed elsewhere in the study area and the United States that did not support the species.

Plant communities.-Chara hormemannii occurred as a large monospecific stand in the center of the large laguna in Vera Cruz, Mexico (61-9-7-1). Chara zey anica occurred as isolated plants scattered around the periphery of the above population and near the banks. Ruppia maritima was abundant near the banks and in large isolated tufts throughout the central part of the laguna but did not merge with the Chara hornemannii population. No charophytes were observed in this habitat in January 1963. However, the nearby sha110w-pool locality (63-1-24-4) supported numerous large isolated tufts of $\underline{\mathrm{C}}$. hormemannii intermixed with similar tufts of Nitella hyalina. Sparse amounts of Chara zexlanica occurred in shallower waters near the banks in close association with species of Najas, Potamogeton, and Sagittaria. This Iocality did not support charophytes in September 1961. Figure Eight Lake, Chaves County, New Mexico was observed in August 
1963 and September 1964. On both occasions the lake was separated into two parts due to low water level. Chara hornemannil completely dominated the northerm part of the lake, forming a bed which extended from an emersed position at the banks to a depth of at least $5 \mathrm{~m}$. Chara aspera occupied a small area in the shallower waters of this habitat. The southern part of the lake supported a luxuriant growth of Batophora oerstedii (vide Proctor, 1961). No charophytes were recorded from this part of the lake but they may have been present. Other lakes of the same series as Figure Eight Lake supported dense beds of Ruppia maritima.

Chara homemannii was rare and immature in the earthen tank locality in Chaves County, New Mexico (64-9-10-7). Other charophytes in this habitat included $\underline{\text { C. contraria, }}$ C. hispida, and Nitellopsis bulbillifera.

MORPHOLOGY, CYTOLOGY, AND TAXONOMY: Specimens of Chara hornemanni1 were quite consistent in particular localities. However, collection 64-9-10-8 displayed marked variations in height, ranging from a few centimeters to $2.13 \mathrm{~m}$. This size range appeared to be a direct result of the variation in water depth. Marked variation did occur between specimens from different localities. Such variation is demonstrated by a comparison of specimens from Vera Cruz, Mexico and Chaves County, New Mexico (Table 25). Both collections were made in September but they were separated by three years and about 1000 miles. In general, the New Mexico plants were larger (vegetative and reproductive structures) and displayed a greater number of parts (branchlet and segment number). The only apparent reduction in the New Mexico plants as compared with the plants from Mexico was the number of oospore striae. One major difference between the specimens was the presence of large unicellular bulbils on the New Mexico plants and the lack of them on the Mexico plants. This difference may be of considerable importance, but at present it is not known for certain that bulbils did 
Table 25. A comparison of Chara hornemannif from Vera Cruz, Mexico and from Chaves County, New Mexico (including 5 plants of each sex from each collection).

\begin{tabular}{|c|c|c|c|c|c|}
\hline SPECMMNS & $\begin{array}{l}\text { MAIN AXES } \\
\text { height }\end{array}$ & diam. & $\begin{array}{l}\text { BR A N C H I E T S } \\
\text { no. length no. }\end{array}$ & seg. & $\begin{array}{l}\text { ANTHERIDIA } \\
\text { diameter }\end{array}$ \\
\hline $\begin{array}{l}61-9-7-1 \\
(\text { Vera Cruz) }\end{array}$ & $\begin{array}{c}\text { to } 35 \\
\text { cm }\end{array}$ & to 1250 & $\begin{array}{l}(8-) \\
9-10 \\
(-11)\end{array} \quad$ cm $6.5 \quad(5-)$ & $6-7$ & $\begin{array}{l}945-1120 \\
\text { M } 1032\end{array}$ \\
\hline $\begin{array}{l}64-9-10-8 \\
\text { (New Mexico) }\end{array}$ & $\begin{array}{l}\text { to } 213 \\
\mathrm{~cm}\end{array}$ & to 1600 & $\begin{array}{ll}(9-) & \text { to } 6.2 \quad(6-) \\
10-12 & \mathrm{~cm}\end{array}$ & $7-8$ & $\begin{array}{l}1075-1170 \\
\text { M } 1117\end{array}$ \\
\hline
\end{tabular}

OOGONIA CORONULA OOSPORES

\begin{tabular}{lccccccc} 
length & width & height & width & length & width & striae & D.E.A. \\
\hline $\begin{array}{l}1010-1095 \\
\text { M 1067 }\end{array}$ & $\begin{array}{c}555-630 \\
597\end{array}$ & $\begin{array}{c}150-185 \\
164\end{array}$ & $\begin{array}{c}195-225 \\
208\end{array}$ & $\begin{array}{c}585-705 \\
642\end{array}$ & $\begin{array}{c}350-410 \\
385\end{array}$ & $9-10$ & $\begin{array}{c}61-76 \\
71\end{array}$
\end{tabular}

$\begin{array}{lccccccc}1160-1330 & 690-735 & 180-225 & 210-260 & 675-750 & 390-435 & 8-9 & 68-95 \\ \text { M } 1264 & 713 & 230 & 241 & 713 & 414 & & 80\end{array}$

$M=$ mean 
not occur on some plants in the Mexican population.

Although there are significant differences between the specimens, no separation into infraspecific taxa can be made. These differences, however, can be interpreted as being indicative of minor evolutionary tendencies which may be correlative with the northern advancement of the species.

A chromosome number of 28 was determined for specimens from each collection except 64-9-10-7. The chromosome number of 28 is contrary to the $I_{4}$ number found in most dioecious species of Chara.

Presently Chara hornemannil presents no major taxonomic problem. The species is well separated morphologically, cytologically, and ecologically from its nearest relatives. However, a more complete understanding of this species will doubtlessly uncover taxonomic problems below the species level. 
Chara aspera Detharding ex Willdenow (1809:298). C. globularis var. aspera $f$. aspera Wood (1962:11).

LITERATURE FOR THE STUDY AREA: Braun and Nordstedt (1882), Allen (1882), Robinson (1906), and Proctor (1961). See also Daily (1944), Daily and Kiener (1956), and Allen (1951).

DESCRIPTION OF SPECTMENS (including 5 specimens from each collection): Plants dioecious (male and female plants similar), 10-30 cm high, appearing rather delicate and spiny, medium green to gray-green, moderately to heavily incrusted with lime. Main axes 450-700 $\mu$ in diameter; cortex triplostichous but very irregular, frequently appearing diplostichous, primary and secondary series of variable thickness; spine cells abundant, macroscopic, solitary but occasionally fasciculate, 300-1500 $\mu$ long (rarely occurring as papillae), straight or curved, narrow and acuminate, but not always sharp. Stipulodes diplostephanous, 2 sets alternating with branchlets, both tiers equally developed, 500-1075 $\mu$ long (sometimes aberrant), variously curved, narrow, and acuminate. Branchlets usually curved, 8-9 in a whorl, 1.0-2.5 cm long; consisting of 6-8 segments, all of which are corticated except 1 or $2(-3)$ distal ones, uncorticated penultimate segment usually short but sornetimes elongate, terminal segment short and acuminate. Bract cells well developed above all corticated segments, anteriors 2, 600-1290 $\mu$ long; posteriors (including laterals) 3-5, 300-990 $\mu$ long (rarely reduced to papillae). Bracteoles (associated with oogonium only) 800-1720 $\mu$ long, narrow and acuminate. Bractlet 700-1505 $\mu$ long, similar to bracteoles. Gametangia-male and female on separate plants. Oogonia (no mature ones seen) solitary at first 3 branchlet nodes; coronulae spreading. Oospores (none seen). Antheridia solitary at first 4 nodes, frequently aborted at first node, 645-795 $\mu$ in diameter, 8-scutate. 
Fig. 36. Chara aspera (61-4-7-8 male plant). Whorl of mature branchlets; also showing details of stipulodes and axial cortex, X. 20 . 


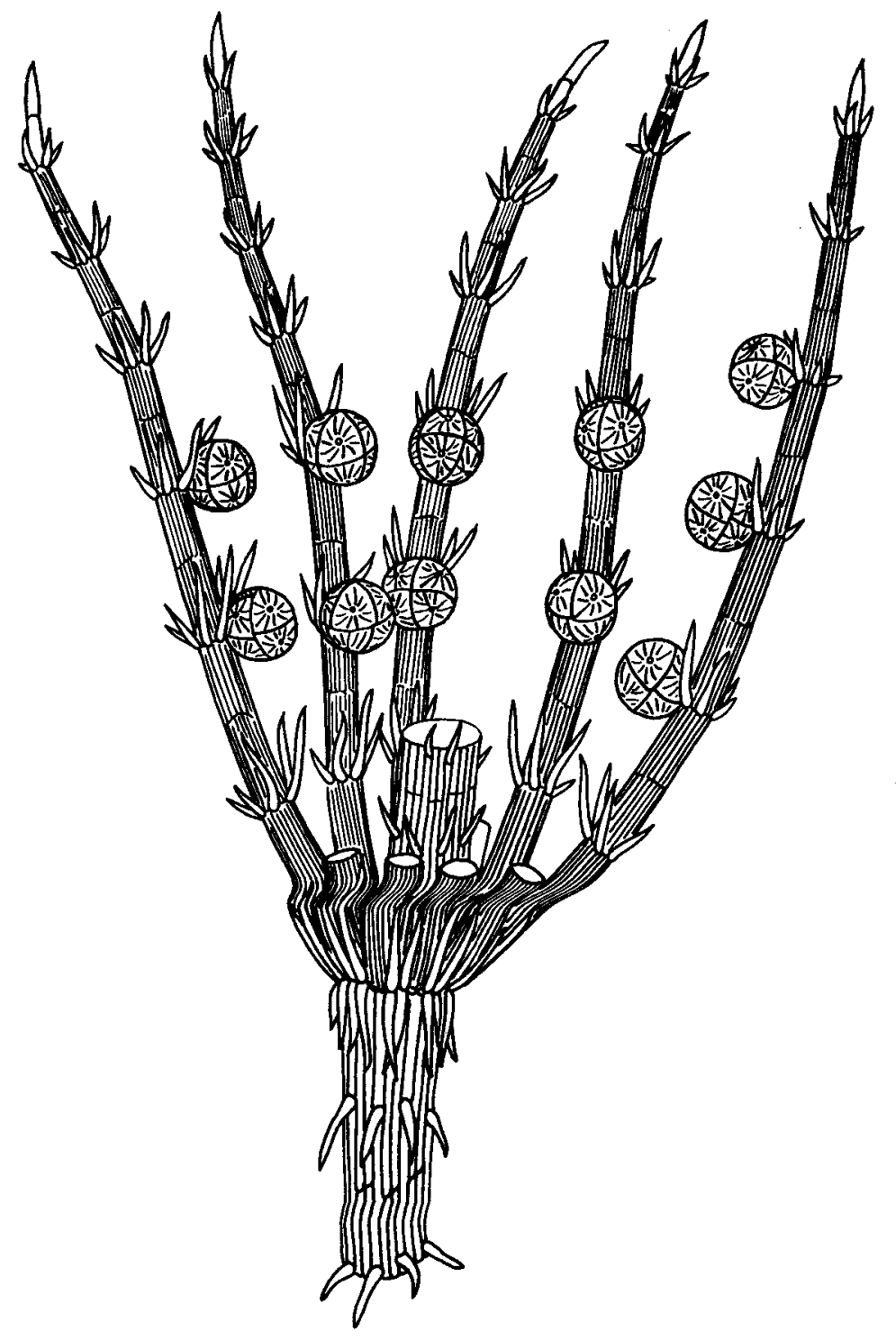


Measurements of oogonia and oospores of $\underline{C}$. aspera (including specimens from the study area) given by Robinson (1906) are as follows: Oogonia $750-900 \mu$ long, 400-575 $\mu$ wide; coronulae $140 \mu$ high, 160-180 $\mu$ wide; and oospores black, 440-650 $\mu$ long, 280-400 $\mu$ with striae of 11-16 ridges. SPECIMENS EXAMINED: NEW MEXICO: (63-8-12-3) Figure Bight Lake, Bottomless Lakes State Park, E Roswell, Chaves Co., New Mexico, D. and Patricia Tindall, Aug. 12, 1963.

COAHUIIA: (6I-4-7-3) Shallow temporary pool (extremely alkaline and rapidly evaporating), $15 \mathrm{~m}$ in diameter, $3 \mathrm{mi}$. S Cuatro Cienegas, Coahuila, Mexico, D. Tindall and W. Minckley, April 17, 1961. (61-4-7-8 and 61-4-7-10B) In Laguma San Pablo, at mouth of cave stream, $8.5 \mathrm{mi}$. SSW Cuatro Cienegas, Coahuila, Mexico, D. Tindall and W. Minckley, April 7, 1961. (61-4-8-1B) Canal de La Angóstura, $1.6 \mathrm{mi}$. SW Cuatro Cienegas, Coahuila, Mexico, D. Tindall and W. Minckley, April 8, 1961. (61-4-8-4) In swift current of Canal de Ia Angostura, 9 mi. SW Cuatro Cienegas, Coahuila, Mexico, D. Tindall and W. Minckley, April 8, 1961.

TYPE IOCALITY: Germany (Willdenow, 1809).

DISTRIBUTION: Chara aspera appears to be limited to the northern hemisphere; being found in Europe, northern Africa, northern Asia, and North America between $70^{\circ} \mathrm{N}$ and $25^{\circ} \mathrm{N}$ (Zaneveld, 1940; Olsen, 1944; Wood and Imahori, 1959). Iocalities from which the species has been recorded in North America include Newfoundland (Braun and Nordstedt, 1882; Robinson, 1906), Saskatchewan (AI’en, 1882; Allen, 1951), British Columbia (Allen, 1.c.), New York (Allen 1871, 1882; Braun and Nordstedt, 1882; Robinson, 1906; Wood and Muenscher, 1956), Michigan and Missouri (Braun and Nordstedt, 1882), Indiana (Daily, 1953), Nebraska (Daily, 1944; Daily and Kiener, 1956), and New Mexico (Proctor, 1961). Braun and Nordstedt (1882) cited specimens of C. aspera collected by C. Wright during the United States Mexican Boundary 
Survey, 1851-1852. The collection was referred to as Wright 569, "Coll [ection] nov[i] Mex[icana].... in saline pools south of EI Paso...." This probably constitutes the record of $\underline{\mathrm{C}}$. aspera from New Mexico included in Allen (1882) and Robinson (1906). However, the collection data given by Braun and Nordstedt indicate that the species may have been collected in northern Chihuahua or possibly in Texas. The exact locality is of little consequence; a thorough examination of the same general area probably will reveal several habitats supporting the species.

The known distribution of Chara aspera in the study area is shown in Figure 37. The species was observed only in arid regions at elevations between 600 and $1200 \mathrm{~m}$. The species occurs at much lower elevations (to sea level) at more northern latitudes in North America. Examination of several habitats in both eastern and western coastal regions of the study area did not yield the species.

\section{BCOIOGY: Physicochemical features of the habitats. - Chara aspera} displayed a tolerance to both still and swiftly flowing waters. The species flourished in both situations but reached its greatest heights in the swiftcurrent habitats. The species usually occurred on alkaline mud substrates in less than $0.50 \mathrm{~m}$ of clear water. Temperatures were not measured in each locality but cooler waters (19-25 C) appeared to be more suitable for the species. Chara aspera usually occurred in well-lighted open areas. In such areas, the species was at least partially fertile, whereas, in the New Mexico locality where it was heavily shaded only sterile specimens were observed.

Chemical analyses were not carried out on the waters supporting $\underline{C}$. aspera; however, all of the localities appeared quite alkaline. Figure Eight Lake (Chaves Co., New Mexico) is discussed above under $\underline{\text {. }}$ hornemannif. The water in that locality is characterized by high concentrations of calcium, magnesium, sodium, chlorides, and sulfates. 


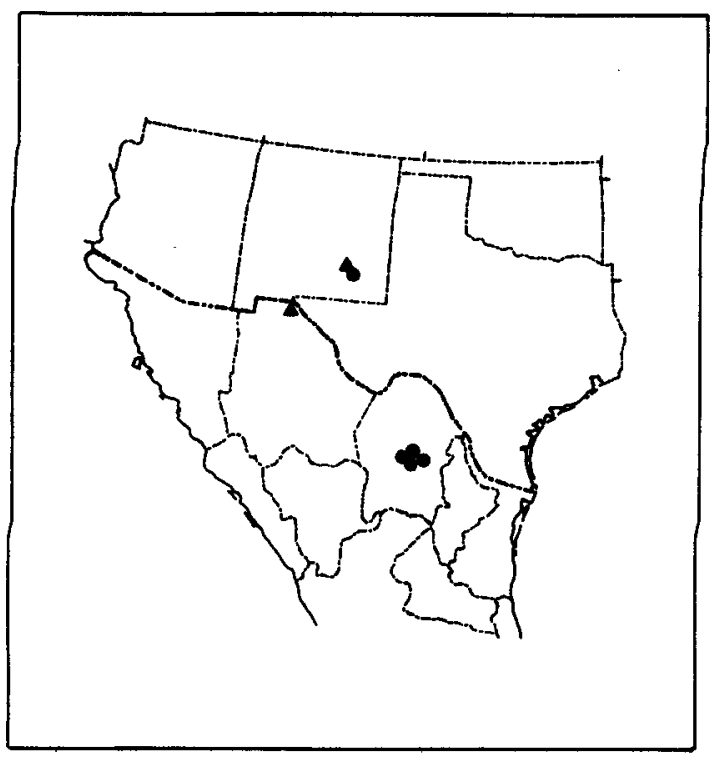

Fig. 37. Distribution of Chara aspera in the the study area; - localities examined during the present study, $\Delta$ localities reported in the Iiterature. 
Plant communities.--Smell beds of $\underline{\text {. }}$ aspera occurred in close association with $\underline{\mathrm{C}}$. hispida in the shallow waters of Figure Eight Lake. Chara homemannii was the dominant plant in the habitat and completely surrounded both species. The shallow pool locality near Cuatro Cienegas, Mexico (61-4-7-3), supported a large, mixed association of $\underline{C}$. aspera (female) and $\underline{C}$. contraria (?). In the nearby Laguna San Pablo, $\underline{\text {. aspera }}$ (male) occurred with $\underline{\text {. }}$ zeylanica and C. contraria. Chara aspera (male) was collected at two points on Canal de Ia Angostura, occurring as isolated tufts in the swiftest part of the canal (64-4-84-), and in association with C. contraria in an area of less current $(61-4-8-1 B)$.

MORPHOLOGY AND CYTOLOGY: Chara aspera was very consistent throughout the study area. Minor variations were observed in length of spine cells, stipulodes, and bract cells. None of the specimens showed a high degree of fertility, and the New Mexico plants were completely sterile. Male and female plants were not collected from the same locality, but in each instance the opposite sex could have been overlooked. Chara aspera is well known for its production of bulbils; however, none was seen on the present specinens.

Chromosome counts of $\mathbb{H}_{4}$ were made on specimens from collections 61-4-7-8, 61-4-7-10B, and 61-4-8-4. This chromosome number is the same as that counted in $\underline{\text {. }}$ aspera from other parts of North America and from Burope (Gillet, 1959; Guerlesquin, 1961, 1963; Hotchkiss, unpublished). Chara aspera does not present a major taxonomic problem; however, Wood (1962) concluded that the species represents only a variety in a large polytypic species, $\underline{\mathrm{C}}$. globularis. Chara leptosperma, which occurs in the study area and also has been considered a variety of $\underline{\mathrm{C}}$. globularis by Wood, occupies an intermediate position between the latter species and C. aspera. A discussion of the relationships between the three species is included below. 
CHARA IEPTOSPERMA A. Braun

Figure 38

Chara leptosperma Braun and Nordstedt (1882:278).

C. globularis var. Ieptosperma Wood (1962:10).

LITERATURE FOR THE STUDY AREA: Braun and Nordstedt (1882), Robinson (1906), Horn af Rantzien (1950), and Cole and Whiteside (1965, as C. globularis).

DESCRIPTION OF SPBCIMENS (including 10 specimens from collection 64-9-3-1): Plants monoecious, to $70 \mathrm{~cm}$ high, yellow-green to medium bright green, lightly incrusted with lime. Main axes to $525 \mu$ in diameter; cortex triplostichous (rarely appearing diplostichous), primary and secondary series equal in width or slightly tylacanthous; spine cells reduced, spherical, 32-54 $\mu$ in diameter. Stipulodes diplostephanous, well developed, never wanting; upper tier 180-630 $\mu$ long; lower tier 60-450 $\mu$ long (frequently a third or fourth stipulode is evident at a single node). Branchlets straight or slightly curved, $1 / 3$ to $1 X$ internode length, (7-) $8(-9)$ in a whorl, (0.9-) $2.2(-3.2) \mathrm{cm}$ long, consisting of (7-) $8(-9)$ segments all of which are corticated except 1 or 2 distal ones, terminal segment conical. Bract cells well developed, narrow and acurninate but not sharp; posteriors 3, 37-525 $\mu$ long; anteriors 2, 375-885 $\mu$ long. Bracteoles 2, 295-975 $\mu$ long. Oogonia $(N=20)$ solitary, $(735-) 774 \pm 5.5(-825) \mu$ long, (315-) $342 \pm 3.5(-367) \mu$ wide; coronulae (120-) $138 \pm 3.8(-172) \mu$ high, (165-) $174 \pm 2.2(-195) \mu$ wide at base. Oospores ( $N=30)$ golden brown, more or less transparent, without a distinct cage, (427-) $465 \pm 3.7(-502)$ $\mu$ long, (195-) $246 \pm 3.3(-285) \mu$ wide; striae of $10-13$ low ridges; D.E.A. (31-) $39 \pm 0.6(-45) \mu$; membrane covered with coarse irregularly shaped granules. Antheridia $(N=38)$ solitary, $(247-) 281 \pm 2.8(-315) \mu$ in diameter, 8-scutate, sheath 29-36 $\mu$ thick. 
Fig. 38. Chara leptosperma $(64-9-3-1)$. A. Whorl of mature branchlets, X 10. B. Details of stipulodes, X 60 . 


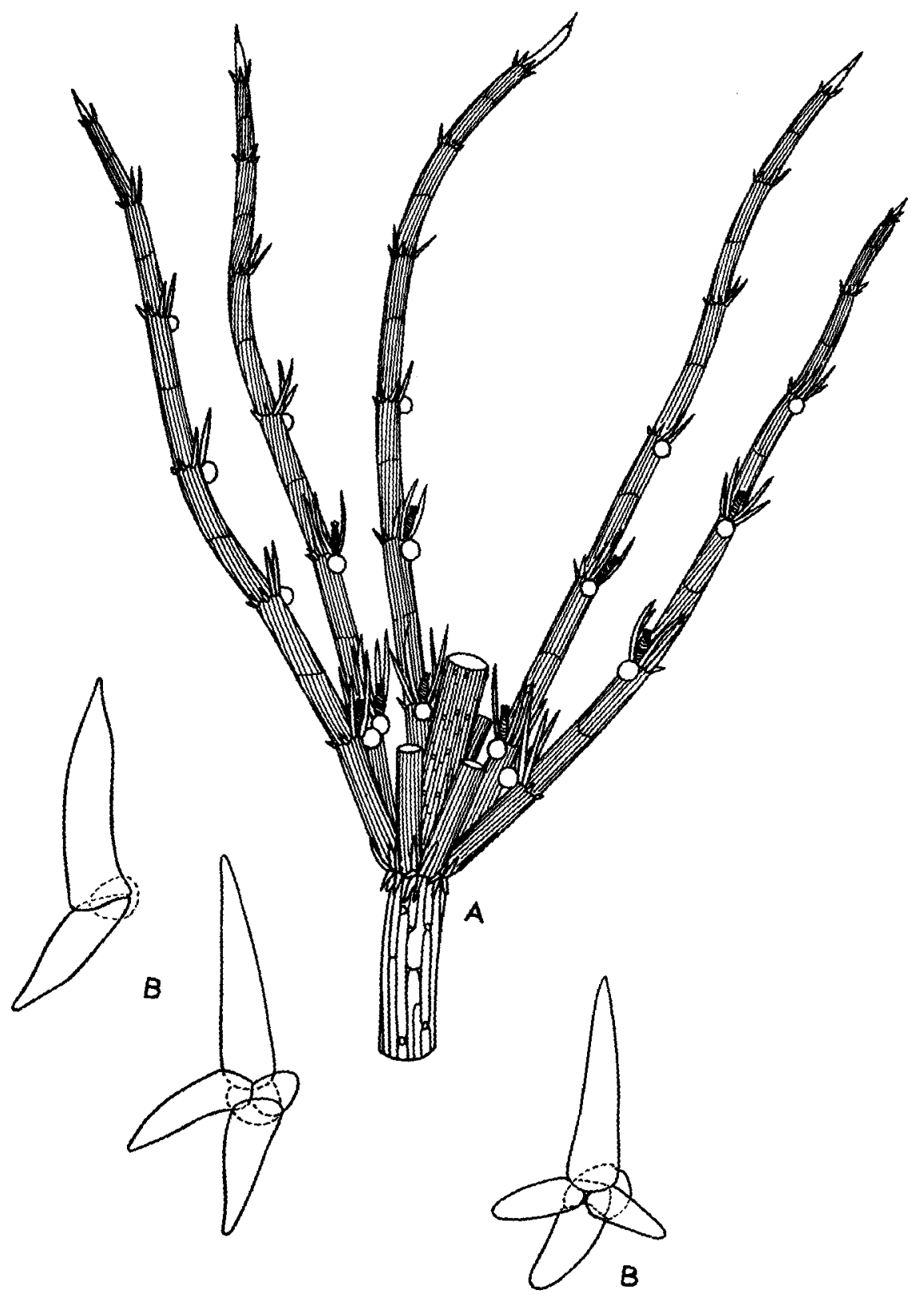


SPBCIMENS EXAMINED: ARIZONA: (64-9-3-1) SmaII earthen tank, fed by artesian sources, San Bernardino Ranch (present owner Warner Glen), $18 \mathrm{mi}$. E D ${ }_{h}^{\circ}$ glas, $2 \mathrm{mi}$. E ranch house, near U.S. -Mexico boundary, Cochise Co., Arizona, D. Tindall, A. Hotchkiss, and W. Minckley, Sept. 3, 1964. (64-6-25-1) Quitobaquito Spring pool, Organ Pipe Cactus National Monument, near U.S.-Mexico boundary, Pima Co., Arizona, G. A. Cole, June 25, 1964. Collection 64-6-25-1 was sent to me by Dr. Gerald Cole, Arizona State University. My original determination was Chara globularis which Dr. Cole subsequently included in a paper on the ecology of Quitogaquito Spring (Cole and Whiteside, 1965). Inasmuch as the collection consisted of young plants which bore no mature gametangia, it can only tentatively be regarded as $\underline{\mathrm{C}}$. leptosperma. However, the specimens are not referable to C. globularis of the present study.

TYPE IOCALITY: Between Mo ro and Rancho nuevo, Vera Cruz, Mexico (Braun and Nordstedt, 1882; coll. by Liebmann, March 1851).

DISTRIBUTION: The collections from Arizona represent the only records of $\mathrm{C}$. leptosperma other than that of the TYPE. The known geographical distribution of the species is included in Figure 39. Although the range is quite large, extensive collecting within the area has not revealed the species. However, specimens from Little Maschaug Pond, Washington County, Rhode Island (Coll. and det, as C. delicatula by R. Wood, in herb. Univ. Louisville) show remarkable similarities to the specimens of the present study.

BCOIOGY: Physicochemical features of the habitats.--Chare leptosperma occurred in somewhat contrasting habitats in Arizona. The species formed a dense bed in about $1 \mathrm{~m}$ of water in the Cochise County locality. Water sampled just above the plants displayed the following features ( $8: 30 \mathrm{AM})$ : temperature, $23 \mathrm{C}$ (air temp., $25 \mathrm{C}$ ); pH 8.3; total alkalinity $299 \mathrm{mg} / \mathrm{l}$; 


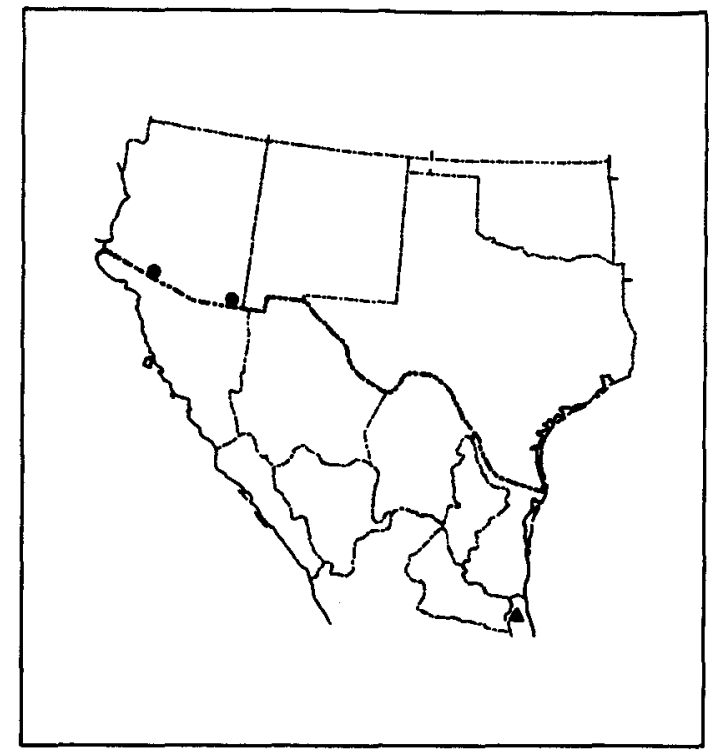

Fig. 39. Distribution of Chara leptosperma in the study area; localities examined during the present study, $\Delta$ locality reported in the literature (TYPE). 
free carbon dioxide, negligible; total chlorides $18.5 \mathrm{mg} / 1$. The substrate on which the Chara grew consisted of firm sand and gravel co ered with a thin layer of mud and organic debris. Part of the population was shaded by extensive riparian vegetation at the time of collection.

A preliminary ecological survey of Quitobaquito Spring has been reported by Cole and Whiteside (1965). Water samples taken from the pool at the time of collection of $\underline{\mathrm{C}}$. leptospema displayed the following features: somewhat turbid; temperature $31.1 \mathrm{C}$ at surface and $30.6 \mathrm{C}$ at bottom (2:30 $\mathrm{PM}$ ), uniformly $27.2 \mathrm{C}$ at dawn (at spring, 23.9 C); $\mathrm{pH}$ measured at sunset and at dawn, 7.8 and 7.6, respectively; total alkalinity, $411 \mathrm{mg} / 1$; free carbon dioxide, ca. $10-20 \mathrm{mg} / 1$; total chlorides, $383 \mathrm{mg} / \mathrm{l}$.

Although there are marked differences in water conditions of the habitats, they are similar in that both receive water from a spring source. Both habitats are characterized by high alkalinity but actual similarities and differences between the two cannot be evaluated on the basis of present data.

Plant commuities.--Other plants associated with $\underline{\text { C. Leptosperma at }}$ the Cochise County locality included Nymphaea odorata, Potamogeton pectinatus, Sagittaria rigida(?), and Heteranthera Iimosa. Oedogonium sp., Bulbochaete sp., Coleochaete nitellatum (rare), Calothrix sp., Rhopolodia gibba (abundant), and Gomphonema sp. occurred as epiphytes on the Chara.

Fragments of young $\underline{\underline{C}}$. contraria and numerous sporelings of $\underline{\underline{C}}$. zeylanica

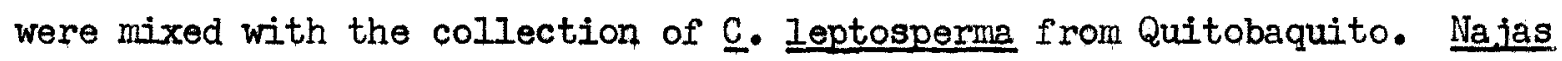
marina also occurred in the pool.

MORPHOLOGY AND CYTOLOGY: The range of variation observed in mature specimens of the species is included in the description. A comparison of Chara leptosperma of the present study with the type description of the species is shown in Table 26. The plants are quite similar in respect to 
Table 26. A comparison of 10 specimens of Chara leptosperma of the present study (A) with the description of the TYPE specimen

(B) from Braun and Nordstedt (1882).

MAIN AXES STIPULODES B R A N C H L E T S BRACTEOLES

height width length no. length no. cort. length

seg. seg.

\begin{tabular}{cccccccc}
\hline A. $\quad \begin{array}{l}\text { to } 70 \\
\mathrm{~cm}\end{array}$ to 525 & $(180-)$ & $(7-)$ & $(0.9-)$ & $(7-)$ & $(5-)$ & $(225-)$ \\
& & 254 & 8 & 2.2 & 8 & 6 & 588 \\
& $(-630)$ & $(-9)$ & $(-3.2)$ & $(-9)$ & $(-7)$ & $(-975)$ \\
& & & & & &
\end{tabular}

$\begin{array}{lllllllll}450- & 350- & 7-9 & \text { c. } 1 & 7-8 & 6-7 & \text { c. } 850 \\ 620 & 360 & & \mathrm{~cm} & & & \mathrm{~cm}\end{array}$

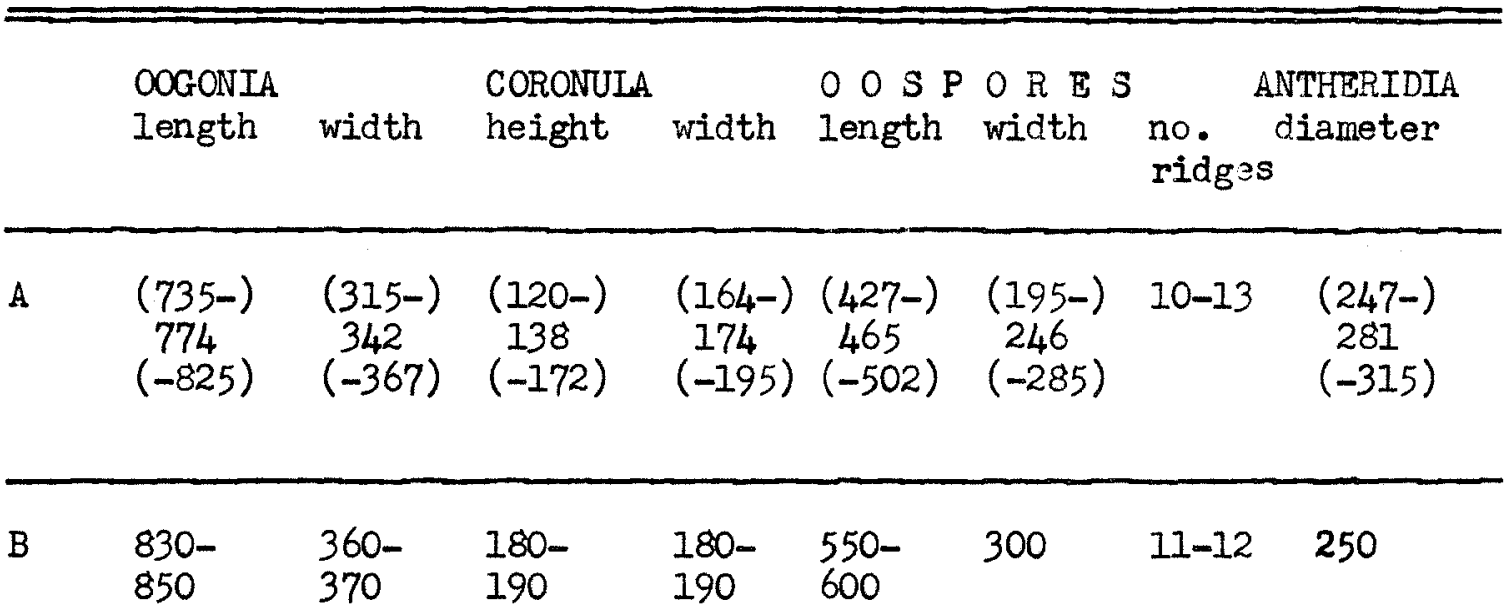


vegetative morphology. Probably the most important similarity is that of stipulode character, which inmediately separates $\underline{\text { C. Ieptosperma from }}$ most of the closely related species in North America. The abnormalities in stipulode development in collection 64-9-3-1 are of no apparant taxonomic importance.

The comparison of gametangial elements shows some marked differences in size. These differences cannot be evaluated until further collections are made. One conspicuous feature of both collections is the golden brown oospore. The color readily distinguishes $\underline{C}$. leptosperma from related species, which for the most part are characterized by dark brown to black oospores.

A chromosome number of 28 was determined for specimens from collection 64-9-3-1. This number is similar to that counted in $\underline{\text {. globularis but }}$ it is also very common throughout the genus.

A discussion of the relationships of $\underline{C}$. leptosperma and closely related species from the study area is included below. 
Figure 40

Chara vulgaris Linnaeus ex parte (1753:1156).

C. globularis Thuillier (1799:472).

C. capillacea Thuillier (1799:474).

C. fragilis Desvaux in Loiseleur (1810:137).

C. fra ilis ssp. capillacea Wallman (1856:85).

C. fragilis B. subverrucosa Braun and Nordstedt (1882:182).

C. globularis var. capillacea Zaneveld (1940:195).

C. globularis forma globularis em. Wood (1962:10).

IITERATURE FOR THE STUDY AREA: Braun and Nordstedt (1882), Robinson (1906), Zaneveld (1940), Horn af Rantzien (1950), Ophel (1952), McCleary (1957), and Hevly (1961). See also Allen (1951), Daily and Kiener (1956), and Daily and Porter (196I).

DESCRIPTION OF SPECIMENS (including 5 specimens from each collection): Plants monoecious, 10-190 $\mathrm{cm}$ high, medium to dark bright green, very lightly to moderately incrusted with lime. Main axes 450-600 $\mu$ in diameter; cortex triplostichous, primary and secondary series equal in width or displaying slightly tylacanthous condition; spine cells obscure, not elongate and flattened horizontally, $30-35 \mu$ wide. Stipulodes usually forming 2 rather disorganized, indistinct tiers; occasionally forming 2 distinct tiers but always reduced and closely appressed to axis. Branchlets straight or slightly curvey, (6-) 7-8 (-9) in a whorl, $1.2-4.3 \mathrm{~cm}$ long, $1 / 3$ to $1 \mathrm{l} / 2 \mathrm{X}$ internode length, consisting of 6-13 segments of which all are corticated except 1-3 short distal ones. Bract cells developed at fertile nodes; anteriors $2(-3), 90-825 \mu$ long; posteriors (3-) $4(-5)$, always obscure. Bracteoles 2, 150-1075 $\mu$ long. Multicellular bulbils present on some specimens. Gametangia conjoined at first $2-4(-5)$ branchlet nodes. Oogonia very rarely 
Fig. 40. Chara globularis. A.-D. Mature oogonia with coronulae; also showing outlines of mature oospores: A. 64-9-8-3A(I), B. $64-9-3-3(2)$, C. $64-9-3-3(1)$, D. 64-9-8-3A(2), X 60. F.-G. Habit sketches of mature plants: F. 64-9-8-3B, G. 64-9-8-3A, X $1 / 2$. H. Terminal segments of mature branchlet $(64-8-29-2), X 30$. I. Sterile branchlet node $(64-8-29-2)$, X 30. J. Details of stipulodes and axial cortex $(64-8-29-2)$, X 30 . 

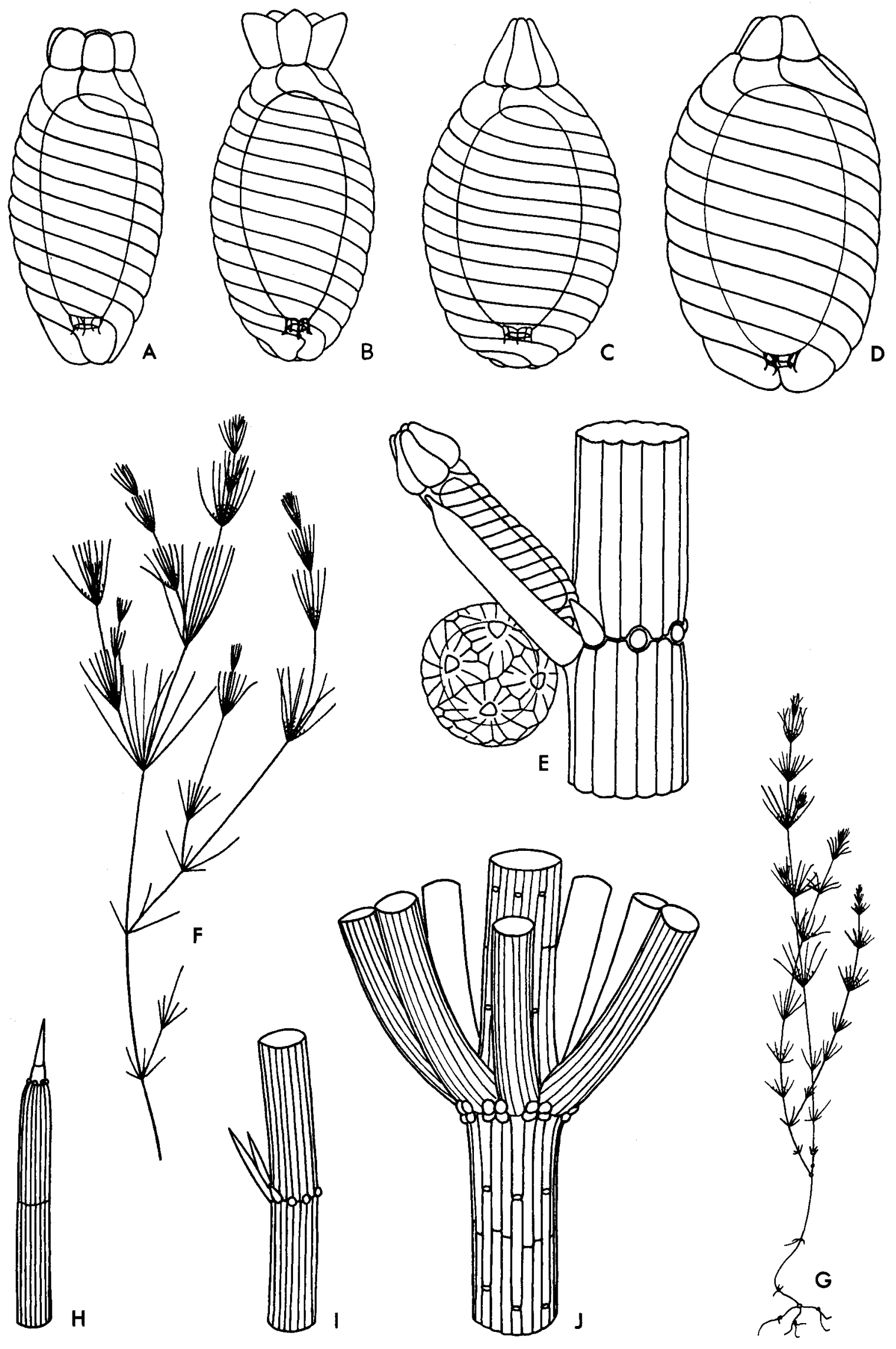
geminate, 820-1075 $\mu$ long, 345-620 $\mu$ wide; coronulae 105-225 $\mu$ high, 165-285 $\mu$ wide. Oospores medium-dark brown to dark brown, frequentIy appearing black, sometimes incrusted, $540-750 \mu$ long, $225-450 \mu$ wide; striae of 11- 14 ridges; D.E.A. 38-65 $\mu$; membrane finely granulate, sometimes appearing smooth. Antheridia solitary, 255-420 $\mu$ in diameter, 8-scutate.

SPECIMENS EXAMINED: KANSAS: $(62-4-26-5)$ Small stripmine pond, Crawford Co. State Park, Crawford Co., Kansas, D. Tinda17, A. Hotchkiss, and W. Minckley, April 26, 1962.

OKIAHOMA: (62-4-27-8) Pond, 4 mi. S Stillwater, State Hwy 40, Payne Co., Oklahoma, D. Tindall, A. Hotchkiss, and W. Minckley, April 27, 1962. (62-4-28-11B) City Lake, 3.1 mi. N Ardmore, U.S. Hwy 77, Carter Co., Oklahoma, D. Tindall, A. Hotchkiss, and W. Minckley, April 28, 1962 .

TEXAS: (63-2-1-2) San Marcos River, in swift current near public swimming area, San Marcos, Hays Co., Texas, D. Tindall and A. Hotchkiss, Feb. 1, 1963.

NEW MEXICO: (64-8-29-2A) Large spring-fed earthen tank on La Cienega Ranch, ca. 17 mi. Sw Santa Fe, U.W. Hwy 85, Santa Fe Co., New Mexico, D. Tindall and A. Hotchkiss, Aug. 29, 1964. (64-8-29-5A) Sma11, recent earthen tank, second tank $W$ of ranch house, Ia Cienega Ranch, ca. 17 mi. SN Santa Fe, U.S. Hwy 85, Santa Fe Co., New Mexico, D. Tindall and A. Hotchkiss, Aug. 29, 1964. (64-9-3-5) Cienega Lake, New Mexico Game Management Area, 2 mi. W U.S. Hwy 80,4 mi. NW Separ, Grant Co., New Mexico, D. Tindall, A. Hotchkiss, and W. Minckley, Sopt. 3, 1964. (64.9-4-1) Barthen tank (pumped ground water), 11.9 mi. W Deming, U.S. Hwy 80, Luna Co., New Mexico, D. Tindall, A. Hotchkiss, and W. Minckley, Sept, 4, 1965. (64-9-9-2) Roberts Lake (large reservoir), $25 \mathrm{mi}$. NNB Silver City, State Hwy 25, Grant Co., New Mexico, D. Tindall and A. Hotchkiss, Sept. 9, 1964. (64-9-9-4) Golf Course Pond at entrance to Rio Mimbres Country Club, E Deming, U.S. Hwy 70, Luna Co., New Mexico, D. Tindall and A. Hotchkiss, Sept. 9, 1964. 
ARIZONA: (64-8-30-2) Large spring-fed lake, $1 \mathrm{mi}$. E Vernon intersection on U.S. Hwy 60, Apache Co., Arizona, D. Tindall and A. Hotchkiss, Aug. 30, 1964. (64-9-1-1B) Canoa Iake, 7 mi. N Amade, off U.S. Hwy 89, Pima Co., Arizona, D. Tindall, A. Hotchkiss, and W. Minckley, Sept. 1, 1964. (64-9-3-3) Middle Fork of Cave Creek (small reservoir) at Herb Martyr Forest Camp, Coronado National Forest, Cochise Co., Arizona, D. Tindall, A. Hotchkiss, and W. Minckley, Sept. 3, 1964. (64-9-7-3) Two small earthen tanks, E side of State Hwy 79, just S Schnebly Hill Road intersection (ca. 15 mi. S Flagstaff), Coconino Co., Arizona, D. Tindall and A. Hotchkiss, Sept. 7, 1964. (64-9-8-1) Small earthen tank (overflow of Apache Cove Lake), 1 mi. N Lakeside, State Hwy 173, Navajo Co., Arizona, D. Tindall and A. Hotchkiss, Sept. 8, 1964. (64-9-8-7) Luna Lake, head waters of the San Franscisco River, $5 \mathrm{mi}$. B Alpine, Apache Co., Arizona, D. Tindall and A. Hotchkiss, Sept. 8, 1964.

CHIHUAHUA: (WM939) Small drying pool of Rio Santa Maria, $5.8 \mathrm{mi}$. W, I mi. N Galeana, Chihuahua, Mexico, W. Minckley, May 29, 1964. (WM943) Rio Piedras Vordes, $10.7 \mathrm{mt}$. by road W Colonia Juarez, Chihuahua, Mexico, W. Minckley, May 30, 1964.

DURANGO: (63-8-9-1) Stream, in swift current below large reservoir, $2 I$ mi. N Durango, Mex. Hwy 45, Durango, Mexico, D. and Patricia Tindall, Aug. 9, 1963.

TYPE IOCALITY: France (Thwi]lier, 1799).

DISTRIBUTION: Chara globularis is a cosmopolitan species occurring on all major continents (Wood and Imahori, 1959). The species is widely distributed throughout North America but only those records of interest in respect to the study area are included below.

Braun and Nordstedt (1882) reported the species from Texas, New Mexico, Nevada (var. capillacea), California, and Mexico (north of Mexicc City). 
Ophel (1952) reported a single collection (var. capillacea) from near Ardmore, Carter County, Oklahoma. Single collections of the species were reported from Apache and Navajo Counties, Arizona (McCleary, 1957), and from Pena Blanca Iake, Santa Cruz County, Arizona (Hevly, 1961). Other collections from North Anerica which are of interest with regard to the study area include those reported from British Columbia (var. capillacea, Allen, 1951), Wyoming (Daily and Porter, 1961), and Nebraska (Daily and Kiener, 1956). South American countries from which the species has been reported include Uruguay, Argentina, Peru, Bolivia, and Chile (Horn af Rantzien, 1950).

The known distribution of $\underline{C}$. globularis in the study area is included in Figure 41. The species occurs in greatest concentration in highland areas. Extensive examination of habitats in desert and coastal areas did not yield the species.

ECOLOGY: Physicochemical features of the habitats.--Various data from the habitats found to support Chara globularis are included in Table 27. These data indicate that the species occupies a relatively narrow range of environmental conditions in the study area. The species shows a particular preference to quiet bodies of water, but it was observed on two occasions in swiftly flowing waters. In the swift water, the species was well developed vegetatively but was conpletely sterile. The occurrence of $\underline{\text {. globularis }}$ was distinctly correlated with sandy-bottomed areas of cool bodies of water which were characterized for the most part by a moderate to high alkalinity and a moderately to highly alkaline $\mathrm{pH}$. In direct relation to the latter conditions, the species regularly occurred in waters void of free carbon dioxide. High concentrations of chloride were not recorded for the waters supporting the species. The various waters not tested for chlorides showed no signs of being brackish. The data in Table 27 for New Mexico and Arizona illustrate the general conditions which characterized 


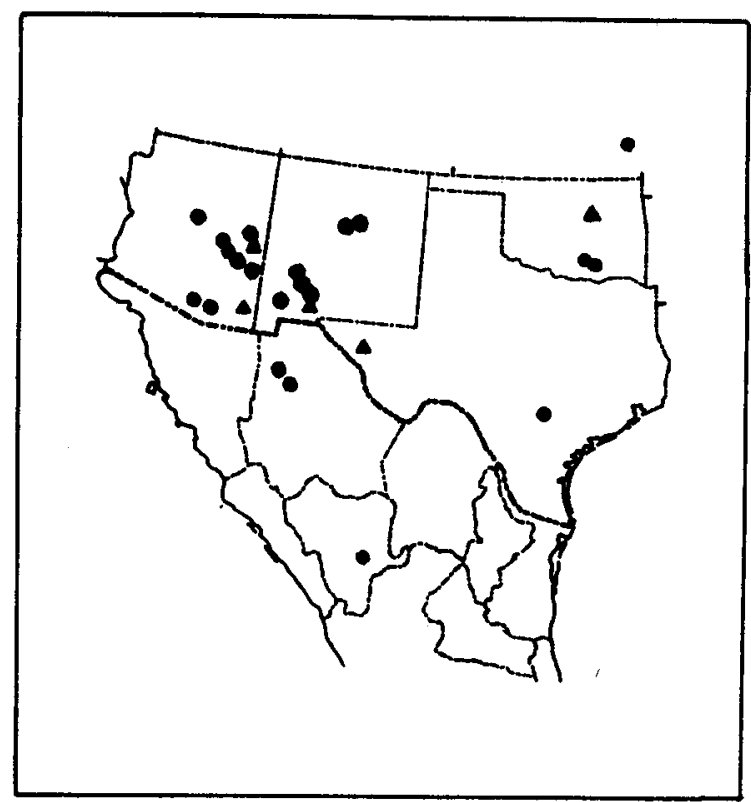

Fig. 41. Distribution of Chara globularis in the study area; localities examined during the present study, $\Delta$ localities reported in the Iiterature. 
Table 27. Physicochemical features of habitats supporting Chara globularis.

\begin{tabular}{|c|c|c|c|c|c|c|c|c|c|c|c|c|}
\hline Specimens & Locality & Habitat & Substrate & Depth & $\begin{array}{l}\text { Tur- } \\
\text { bidity }\end{array}$ & Light & $\begin{array}{l}\text { Teinpe } \\
\text { ajr }\end{array}$ & $\begin{array}{l}\text { rature } \\
\text { water }\end{array}$ & $\mathrm{pH}$ & Alk. & $\mathrm{CO}_{2}$ & Cl. \\
\hline $62-4-26-5$ & Kansas & $\begin{array}{l}\text { stripmine } \\
\text { pond }\end{array}$ & $\begin{array}{l}\text { sand-clay- } \\
\text { mud }\end{array}$ & 0.5 & 0 & open & 29.0 & 23.0 & 7.65 & 294 & 13.0 & - \\
\hline $62-4-27-8$ & Oklahoma & large pond & sand-rnud & 0.5 & 0 & open & - & 29.0 & 9.0 & 117 & 0.0 & - \\
\hline $63-2-1-2$ & Texas & swift river & sand-gravel & 0.4 & 0 & open & - & 23.2 & 7.5 & 260 & 16.0 & - \\
\hline $64-8-29-2 A$ & $\begin{array}{l}\text { New } \\
\text { Mexico }\end{array}$ & $\begin{array}{l}\text { large spring- } \\
\text { fed tank }\end{array}$ & sand-mud & -1.0 & 0 & open & 26.0 & 20.0 & 9.2 & 280 & 0.0 & 15.0 \\
\hline $64-8-29-5 A$ & $\begin{array}{l}\text { New } \\
\text { Mexico }\end{array}$ & $\operatorname{sma} 11$ tank & sand-nadd & -0.2 & 0 & open & 27.0 & 20.0 & 8.5 & 122 & 0.0 & 8.5 \\
\hline $64-9-3-5$ & $\begin{array}{l}\text { New } \\
\text { Mexico }\end{array}$ & small lake & $\begin{array}{l}\text { marl- } \\
\text { organic }\end{array}$ & -0.3 & + & $\begin{array}{l}\text { open \& } \\
\text { shaded }\end{array}$ & 32.5 & 30.0 & 9.0 & - & 0.0 & - \\
\hline $64-9-4-1$ & $\begin{array}{l}\text { New } \\
\text { Niexico }\end{array}$ & small tank & sand-mud & -1.0 & + & shaded & 29.0 & $24 \cdot 5$ & 8.3 & 160 & 0.0 & 20.5 \\
\hline $64-9-9-2$ & $\begin{array}{l}\text { New } \\
\text { Mexico }\end{array}$ & $\begin{array}{l}\text { large reser- } \\
\text { voir }\end{array}$ & sand-mid & -0.45 & + & open & 23.0 & 21.5 & 8.4 & 140 & 0.0 & - \\
\hline $64-9-9-4$ & $\begin{array}{l}\text { New } \\
\text { Hexico }\end{array}$ & small tank & mud & -1.0 & 0 & $\begin{array}{l}\text { open \& } \\
\text { shaded }\end{array}$ & 27.0 & 27.0 & 8.9 & 127 & 0.0 & - \\
\hline $64-8-30-2$ & Arizona & lake & sand-rnud & -0.3 & 0 & open & 26.0 & 20.0 & 9.4 & 102 & 0.0 & 6.5 \\
\hline $64-9-1-18$ & Arizona & small lake & mud & -1.0 & + & open & 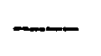 & 23.0 & 7.8 & - & - & - \\
\hline $64-9-3-3$ & Arizona & $\begin{array}{l}\text { stream } \\
\text { reservoir }\end{array}$ & $\begin{array}{l}\text { sand- } \\
\text { gravel }\end{array}$ & -4.0 & 0 & $\begin{array}{l}\text { open \& } \\
\text { shaded }\end{array}$ & 28.0 & 21.0 & 8.2 & 123 & 1.0 & 18.5 \\
\hline $64-9-7-3$ & Arizona & small tank & sand-mud & -1.0 & 0 & open & 23.0 & 20.0 & 7.85 & 109 & 2.5 & - \\
\hline $64-9-8-1$ & Arizona & $\operatorname{sma} 11 \operatorname{tank}$ & sand-mud & -1.0 & + & open & 24.0 & 24.0 & 7.8 & 148 & 3.5 & 15.0 \\
\hline $64-9-8-3$ & Arizona & $\begin{array}{l}\text { sma11 reser- } \\
\text { voir }\end{array}$ & sand-mud & -0.4 & + & open & 26.5 & 24.0 & 8.2 & 129 & 1.0 & 12.5 \\
\hline $64-9-8-7$ & Arizona & $\begin{array}{l}\text { large reser- } \\
\text { voir }\end{array}$ & $\begin{array}{l}\text { sand-mud- } \\
\text { organic }\end{array}$ & -3.0 & + & open & 18.5 & 18.5 & 9.6 & 137 & 0.0 & $\ldots$ \\
\hline $63-8-9-1$ & Durango & swift stream & sand & -0.1 & 0 & $\begin{array}{l}\text { open \& } \\
\text { shaded }\end{array}$ & 23.0 & 20.0 & 7.8 & 93 & 2.5 & 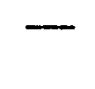 \\
\hline
\end{tabular}


the majority of medium-sized bodies of water which supported extensive vegetation in the highland areas examined during this study.

P1ant communities.--Chara globularis usually occurred in association with various algae, vascular plants, and with one or more of the following charophytes; C. braunii, ․ contraria, ․ vulgaris, Nitella clavata, and N. missouriensis. The prominence and distribution of Chara globularis in the habitats varied considerably.

A mixed association of charophytes occurred as a dense "chara zone" around the southerm edge of one large spring-fed lake (Apache Co., Arizona, 64-8-30-2). The zone extended out from the bank to about $2.5 \mathrm{~m}$ and to a depth of $1 \mathrm{~m}$. The dominant charophyte in the zone was $\underline{\mathrm{C}}$. braunii. Chara globularis, Nitella clavata, and to a lesser degree $\underline{\text { N. missouriensis, occurred }}$ as single plants or small tufts sporadically distributed throughout the dense stand of Chara braunii. Although $\underline{C}$. globularis was greatly overshadowed by $\underline{\mathrm{C}}$. braunii, the species was well developed and displayed numerous ripe oospores. The predominant higher plant associated with the charophytes was Potamogeton pectinatus which occurred as large isolated stands in the deeper water but occasionally merged with the chara zone. The principal epiphytes on . . globularis were Bulbochaeta sp., Dedogonium sp., Cymbella sp., Denticula sp., Gompnonema sp., and Cocconeis placentula. Palmodictyon varium was very common in the chara zone. A somewhat similar association was observed in Apache Cove Lake (Navajo Co., Arizona, 64-9-8-3). However, no distinct chara zone had developed. Small isolated tufts of Chara globularis, Nitella clavata, and $\underline{N}$. missouriensis were irregularly distributed in shallow water

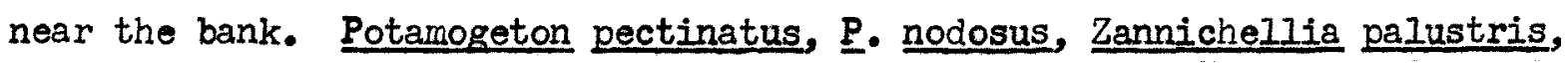
Blodea canadensis, and Myriophyllum $\mathrm{sp}$. occurred in the near vicinity of the charophytes. Energent forms (not in direct association with the charophytes) included species of Alisma, Typha, Sparganium, and Eleocharis. A mixed 
association of Chara globularis, $\underline{C}$. braunii, Nitella missouriensis, Potamogeton foliosus, and Ranunculus aquatilis was observed in a small, shallow earthen tank (Coconino Co., Arizona, 64-9-7-3). In stream habitats where Chara globularis was observed in swift current areas (Hays Co., Texas, 63-2-1-2 and Durango, Mexico, 63-8-9-1), C. braunif also was observed but usually in quieter water. Sagittaria sp., Najas guadalupensis, Batrachospernum sp., Thorea sp., and small tufts of Chara brunifi oc: urred on riffles near C. globularis in the Texas locality.

One other association which included $\underline{\mathrm{C}}$. globularis and $\underline{\mathrm{C}}$. braunij was observed in Roberts Iake (Grant Co., New Mexico, 64-9-9-2). Chara contraria also occurred in close association with these species. All three species were sparsely distributed and were not observed in any definite arrangement. Higher plants observed in direct association with the charophytes included Potamogeton sp., P. pectinatus, P. foliosus, Zannichellia palustris, and Myricphyllum sp. Nasturtium officinale was abundant near small spring areas. Hydrodictyon reticulatum and Spirogyra spp. formed small floating mats near the Chara.

In contrast to the chara zone described above, Myriophyllum sp. formed a thick zone around the edge of a medium size lake in southern Arizona (Canoa Iake, Pima Co., 64-9-1-IB). Chara globularis and C. contraria was sparingly distributed throughout extensive beds of Potamogeton spp. In the central portion of the lake. Similarly, Potamogeton foliosus formed a distinct zone around the edge of a small earthen tank in southern New Mexico (Luna Co., 64-9-9-4); whereas, C. globularis occurred as a dense pure stand covering the entire central bottom area. However, in a similar habitat in the same county $(64-9-4-1)$, C. globularis occurred as isolated beds in deeper water with Potamogeton pectinatus and Najas guadaIupensis distributed randomly throughout the tank. Bpiphytes on C. globularis 
included Calothrix sp., Dedogonium sp., Cymbella tumida, Denticula, and an extensive growth of Gomphonema spp. Several earthen tanks observed in the same area lacked any charophytic flora but maintained nearly pure stands of Najas guadalupensis.

Associations including $\underline{\mathrm{C}}$. globularis and $\underline{\mathrm{C}}$. vulgaris were observed in contrasting habitats. In a large spring-fed earthen tank in Santa $\mathrm{Fe}$ County, New Mexico $(64-8-29-2 A)$, C. Rlobularis occurred in isolated tufts

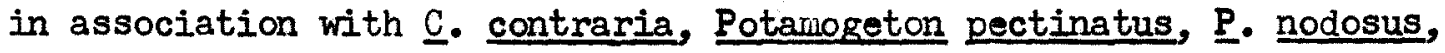
Ranunculus aquatilis, and Ceratophyllum demersum in the shallow, mud-bottomed areas around the edge, whereas $\underline{G}$. vulgaris was the dominant vegetation covering the entire bottom in the deeper water. Nasturtium officinale occurred near the spring source. A small recent tank near the above locality supported $\underline{\text {. }}$ globularis, $\underline{\text {. }}$ vulgaris, and $\underline{\mathrm{C}}$. contraria (?) as small isolated tufts in shallow water. The small (deep) reservoir of Cave Creek (Cochise

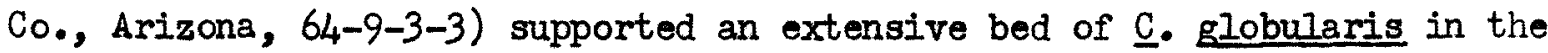
deep channel and dense beds of $\underline{\mathrm{C}}$. vulgaris along the banks in shallower water. Both species were very well developed and did not appear to be competing for bottom area. The major epiphytic flora associated with $\underline{\mathrm{C}}$. globularis included Rhopolodia gibba, Epithemia sp., Denticula sp., and Coleochaete sp.

In a small portion of Luna Iake (Apache Co., Arizona, 64-9-8-7), C. globularis was observed in $3 \mathrm{~m}$ of water along a steep rocky bank in association with Myriophyllum sp., Ranunculus aquatilis, and floating mats of Spirogyra spp. Abundant epiphytes included Oedogonium spp., Coleochaete sp., Synedra spp., Gomphonema sp., Rhopolodia gibba, Cocconeis placentula, and Denticula sp. Several species of Cosmarium and a tetrasporine alga also were associated with $\underline{\mathrm{C}}$. globularis.

In the one locality where a temperature was recorded as high as 
30 C (Cienega Lake, Grant Co., New Mexico, 64-9-3-5), C. globularis was being completely covered by Dedogonium sp., Gomphonema sp., and Cocconeis placentula. Most of the water surface was covered by mats of Spirogyra spp. The stripmine pone in southern Kansas (Crawford Co., 62-4-26-5) maintained a nearly pure stand of $\underline{\mathrm{C}}$. globularis and associated epiphytes. However, similar habiats in the same area supported luxuriant stands of other charophytes. The species occurred as sparse young plants in beds of C. Schaffneri in City Lake near Ardmore, Oklahoma (Carter Co., 62-4-28IIB), and as a pure stand in a pond south of Stillwater, Oklahoma (Payne Co., 62-4-27-8).

MORPHOLOGY AND CYTOLOGY: AII of the specimens examined from the study area appear to represent a single taxon, Chara globularis var. capillacea. The specimens were quite consistent with regard to axis cortication, spine cells, stipulodes, bracteoles, bract cells, and number of branchlets. The most conspicuous differences between populations include height of plants, number of branchlet segments, and size and shape of gametangia and oospores. The arrangement of specimens in Table 28 according to number of branchlet segments forms a more or less continuous series. However, the inclusion of size and shape of gametangia and oospores results in a segregation of specimens into five general categories (A-B, Table 28). Collections $64-9-8-3 \mathrm{~A}(1$ and 2$)$ and $64-9-8-3 B$ represent three distinct morphs from a single population. Specimens $A$ and $B$ were separated at the time of collection because of their somewhat contrasting habits (Fig. 40). Specimens representing morphs 1 and 2 of collection 3A were separated in the laboratory because of consistent differences in the size of their gametangia and oospores. These morphs occurred on separate plants of the same vegetative form. Collection 64-9-3-3 also displayed two distinct gametangial morphs on separate plants of a single vegetative type. 
Table 28. A comparison of specimens of Chara globularis examined from the study area. Specimens are arranged in five groups which are considered to represent distinct morphs.

\begin{tabular}{|c|c|c|c|c|c|c|c|c|c|c|c|c|c|c|c|c|c|c|}
\hline & SPECIMERS & $\begin{array}{l}\text { MAIN AXE } \\
\text { height } \\
\text { (ca) }\end{array}$ & diam. & $\begin{array}{l}\text { B R A } \\
\text { no. }\end{array}$ & $\begin{array}{l}\text { A N C H L } \\
\text { length } \\
\text { (cu) }\end{array}$ & $\begin{array}{l}\text { E T S } \\
\text { no. } \\
\text { segs. }\end{array}$ & $\begin{array}{l}\text { no. cort. } \\
\text { segs. }\end{array}$ & & $\begin{array}{l}\text { OOG O N } \\
\text { length }\end{array}$ & I A & $\begin{array}{l}\text { COR } 0 \\
\text { height }\end{array}$ & $\begin{array}{l}\text { N } 0 \text { I } A \\
\text { width }\end{array}$ & character & $\begin{array}{l}\text { OOSP ORES } \\
\text { length width }\end{array}$ & ridges & D.E.A. & cage & $\begin{array}{l}\text { ANTHERIDIA } \\
\text { diameter }\end{array}$ \\
\hline \multirow[t]{2}{*}{ I } & $64-9-3-5$ & - & - & $7-8$ & -3.8 & $\begin{array}{l}(6-) \\
9\end{array}$ & $\begin{array}{r}(4-) \\
6-7\end{array}$ & & IMMATURE & GAMETANGIA & & & & & & & & \\
\hline & $64-9-8-3 A-1$ & -25 & -525 & $7-8$ & -1.7 & $\begin{array}{c}(7-) \\
9 \\
(-10) \\
\end{array}$ & $\begin{array}{r}(5-) \\
7-8 \\
\end{array}$ & 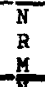 & $\begin{array}{l}20 \\
840-945 \\
887+7.3 \\
\end{array}$ & $\begin{array}{l}375-4.35 \\
403 * 4.9 \\
\end{array}$ & $\begin{array}{l}105-135 \\
218 \pm 6.0 \\
\end{array}$ & $\begin{array}{r}180-225 \\
205 \pm 2.7 \\
\end{array}$ & spreading & $\begin{array}{ll}20 & \\
585-645 & 225-285 \\
616 \pm 4.1 & 256 * 3.3 \\
\end{array}$ & $12-13$ & $\begin{array}{l}42-54 \\
47 \pm 0.9 \\
\end{array}$ & delicate & $\begin{array}{l}50 \\
277-360 \\
325 \pm 2.6 \\
\end{array}$ \\
\hline \multirow[t]{3}{*}{ II } & $64-9-8-7$ & -190 & -600 & $7-8$ & -4.3 & $\begin{array}{c}(6-) \\
9-10 \\
\end{array}$ & $\begin{array}{r}(4-) \\
7-8 \\
\end{array}$ & $\begin{array}{l}\mathrm{N} \\
\mathrm{R} \\
\mathrm{M} \\
\end{array}$ & $\begin{array}{l}13 \\
860-950 \\
918+7.6 \\
\end{array}$ & $\begin{array}{r}345-425 \\
390 \pm 5.7 \\
\end{array}$ & $\begin{array}{l}150-195 \\
177 \pm 4.1 \\
\end{array}$ & $\begin{array}{l}185-225 \\
208+3.9 \\
\end{array}$ & $\begin{array}{l}\text { spreading } \\
\text { slightily }\end{array}$ & $\begin{array}{ll}13 & \\
555-605 & 245-300 \\
594-4.8 & 273 \pm 4 . ? \\
\end{array}$ & $12-13$ & - & thick & $\begin{array}{l}25 \\
315-375 \\
337+3.2 \\
\end{array}$ \\
\hline & $64-9-3-3(2)$ & same as & $64-9-3$ & $-3(1) b$ & below & & & $\begin{array}{r}\mathrm{N} \\
\mathrm{R} \\
\mathrm{M} \\
\end{array}$ & $\begin{array}{l}20 \\
840-990 \\
914+9.8 \\
\end{array}$ & $\begin{array}{l}375-480 \\
430 \pm 6.0 \\
\end{array}$ & $\begin{array}{l}115-165 \\
138+3.3 \\
\end{array}$ & $\begin{array}{l}180-270 \\
230 \pm 5.9 \\
\end{array}$ & spreading & $\begin{array}{ll}20 & \\
562-652 & 270-337 \\
612 \pm 6.3 & 300 \pm 5.0 \\
\end{array}$ & $12-14$ & $\begin{array}{l}38-47 \\
43 \pm 0.5 \\
\end{array}$ & thick & $\begin{array}{c}20 \\
285-330 \\
315\end{array}$ \\
\hline & $64-9-4-1$ & -70 & -510 & $7-8$ & -3.0 & $\stackrel{9}{(-10)}$ & $7-8$ & $\begin{array}{l}N \\
R \\
M \\
\end{array}$ & - & - & - & - & - & $\begin{array}{ll}10 & \\
592-645 & 270-345 \\
619 * 4.8 & 301 \star 8.5 \\
\end{array}$ & $11-13$ & $\begin{array}{l}43-50 \\
46 \pm 0.9\end{array}$ & thick & - \\
\hline \multirow[t]{10}{*}{ III } & $64-8-29-21$ & -19 & -500 & $\begin{array}{r}(6-) \\
7-8 \\
(-9) \\
\end{array}$ & -2.4 & $\begin{array}{c}(8-) \\
9 \\
(-10) \\
\end{array}$ & $\begin{array}{r}(6-) \\
7-8\end{array}$ & $\begin{array}{l}\mathrm{N} \\
\mathrm{R} \\
\mathrm{M} \\
\end{array}$ & $946-990$ & $480-510$ & $202-225$ & $240-285$ & $\begin{array}{l}\text { forming } \\
\text { pyramid }\end{array}$ & $\begin{array}{ll}14 & \\
555-600 & 300-342 \\
581-11.1 & 323+11.2 \\
\end{array}$ & $2^{11-12}$ & $\begin{array}{l}3 \\
45-50 \\
\end{array}$ & delicate & $\begin{array}{l}10 \\
315-345 \\
329+3.3 \\
\end{array}$ \\
\hline & $64-8-29-5 A$ & -12 & -525 & $\begin{array}{r}(6-) \\
7-8 \\
\end{array}$ & -2.2 & $\begin{array}{l}(7-1) \\
9 \\
(-20) \\
\end{array}$ & $\begin{array}{r}(5-) \\
7-8 \\
\end{array}$ & $\begin{array}{l}\mathrm{N} \\
\mathrm{R} \\
\mathrm{M}\end{array}$ & $930-946$ & $502-516$ & $147-150$ & $210-255$ & $\begin{array}{l}\text { forming } \\
\text { pyramid }\end{array}$ & 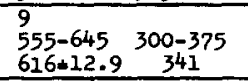 & 12 & $48-50$ & delicate & $\begin{array}{l}18 \\
330-412 \\
376+4.6\end{array}$ \\
\hline & $64-9-8-3 B$ & -32 & -510 & $7-8$ & -3.5 & $\begin{array}{c}(8-) \\
9 \\
(-10) \\
\end{array}$ & $\begin{array}{r}(6-) \\
7-8 \\
(-9) \\
\end{array}$ & $\begin{array}{l}\mathrm{N} \\
\mathrm{R} \\
\mathrm{H} \\
\end{array}$ & 930 & 495 & 155 & 225 & $\begin{array}{l}\text { forming } \\
\text { pyramid }\end{array}$ & $\begin{array}{ll}5 & \\
575-615 & 315-360 \\
598 \pm 8.9 & 338+8.2 \\
\end{array}$ & 12 & $\begin{array}{l}43-50 \\
47 \pm 1.5 \\
\end{array}$ & delicate & $\begin{array}{l}20 \\
315-420 \\
369=4.7\end{array}$ \\
\hline & $64-8-30-2$ & -35 & -450 & $\begin{array}{l}(6-) \\
7 \\
(-8) \\
\end{array}$ & -4.2 & $\begin{array}{l}(9-) \\
11 \\
(-12)\end{array}$ & $\begin{array}{r}(5-) \\
8-9 \\
\end{array}$ & $\begin{array}{r}N \\
R \\
M \\
\end{array}$ & $\begin{array}{l}10 \\
850-920 \\
885 \pm 2.8 \\
\end{array}$ & $\begin{array}{r}375-450 \\
419 * 7.5 \\
\end{array}$ & $\begin{array}{l}150-195 \\
168+5.2 \\
\end{array}$ & $\begin{array}{l}195-225 \\
205 \times 3.1 \\
\end{array}$ & $\begin{array}{l}\text { forming } \\
\text { pyramid }\end{array}$ & $\begin{array}{ll}12 \\
540-630 & 280-360 \\
588+10.2 & 320+6.8 \\
\end{array}$ & 12 & - & delicate & $\begin{array}{l}20 \\
255-330 \\
279+3.4 \\
\end{array}$ \\
\hline & $63-2-1-2$ & -11 & -475 & $7-8$ & -1.2 & $\begin{array}{l}(9-) \\
10-12 \\
\end{array}$ & $\begin{array}{l}(7-) \\
8-10 \\
(-11) \\
\end{array}$ & & STERILE & & & & & & & & & \\
\hline & $63-8-9-1$ & -27 & -500 & 8 & -3.0 & $\begin{array}{l}(10-) \\
11 \\
(-12) \\
\end{array}$ & $\begin{array}{r}(8-) \\
9-10 \\
\end{array}$ & & IMMATURE & GAMETANGIA & & & $\begin{array}{l}\text { forming } \\
\text { pyramid }\end{array}$ & & & & & \\
\hline & $62-4-27-8$ & -10 & - & $7-8$ & -1.5 & $\begin{array}{l}(9-) \\
11-12\end{array}$ & $\begin{array}{l}(8-) \\
9-10 \\
\end{array}$ & & IMMATURE & GAMETANGIA & & & $\begin{array}{l}\text { forming } \\
\text { pyramid }\end{array}$ & & & & & \\
\hline & $64-9-7-3$ & -40 & -465 & $7-8$ & -4.0 & $\begin{array}{l}(8-) \\
10-12 \\
(-13)\end{array}$ & $\begin{array}{l}(6-) \\
7-10 \\
\end{array}$ & & IMMATURE & GAMETANGIA & & & $\begin{array}{l}\text { forming } \\
\text { pyramid }\end{array}$ & & & & & \\
\hline & $64-9-3-3(1)$ & -70 & -500 & $7-8$ & -3.3 & $\begin{array}{l}(9-) \\
12-13\end{array}$ & $\begin{array}{l}(8-) \\
10-11 \\
\end{array}$ & $\begin{array}{l}\mathrm{N} \\
\mathrm{R} \\
\mathrm{M} \\
\end{array}$ & $\begin{array}{l}20 \\
820-950 \\
889+7.5 \\
\end{array}$ & $\begin{array}{l}442-555 \\
494.6 .7 \\
\end{array}$ & $\begin{array}{l}120-165 \\
145 \times 2.7 \\
\end{array}$ & $\begin{array}{r}165-225 \\
200 \times 3.3 \\
\end{array}$ & $\begin{array}{l}\text { forming } \\
\text { pyramid } \\
\end{array}$ & $\begin{array}{ll}20 & \\
562-630 & 300-390 \\
595 \pm 4.7 & 347 \pm 5.4 \\
\end{array}$ & $13-14$ & $\begin{array}{l}40-47 \\
42 \pm 0.5 \\
\end{array}$ & delicate & $\begin{array}{l}30 \\
285-330 \\
315+2.7 \\
\end{array}$ \\
\hline & $62-4-26-5$ & -70 & -490 & $\stackrel{8}{(-9)}$ & -3.0 & $\begin{array}{l}(11-) \\
12-13\end{array}$ & $\begin{array}{l}(9-) \\
10-11\end{array}$ & & IMMATURE & GAMETANGIA & & & variable & & & & & \\
\hline IV & $64-9-8-3 A-2$ & same as & c $64-9$ & $8-3 A-1$ & above & & & $\begin{array}{l}\mathrm{N} \\
\mathrm{R} \\
\mathrm{M} \\
\end{array}$ & $\begin{array}{l}20 \\
900-1075 \\
993+10.9\end{array}$ & $\begin{array}{r}487-570 \\
540=5.6 \\
\end{array}$ & $\begin{array}{l}105-150 \\
132+3.8 \\
\end{array}$ & $\begin{array}{l}225-270 \\
245+3.2 \\
\end{array}$ & $\begin{array}{l}\text { forming } \\
\text { pyramid }\end{array}$ & $\begin{array}{ll}20 & \\
630-750 & 330-390 \\
701+8.2 & 360 * 4.2 \\
\end{array}$ & $12-14$ & $\begin{array}{l}47-61 \\
53 \pm 1.3\end{array}$ & thick & $\begin{array}{l}20 \\
277-360 \\
325\end{array}$ \\
\hline $\mathbf{v}$ & WM 943 & -27 & -550 & ${ }_{8}^{(7-)}$ & -2.3 & $\begin{array}{l}(7-) \\
10-11\end{array}$ & $\begin{array}{l}(5-) \\
8-9\end{array}$ & $\begin{array}{l}\text { N } \\
R \\
M\end{array}$ & $\begin{array}{l}5 \\
990-1030 \\
1000+8.7\end{array}$ & $\begin{array}{l}585-620 \\
602-6.3 \\
\end{array}$ & $\begin{array}{l}150-180 \\
162+6.3\end{array}$ & $\begin{array}{l}225-245 \\
235 * 4.7\end{array}$ & variable & $\begin{array}{ll}10 & \\
637-705 & 390-450 \\
670 \pm 8.9 & 429.6 .2\end{array}$ & $11-12$ & $49-65$ & delicate & $\begin{array}{l}17 \\
345-400 \\
367 \pm 4.0\end{array}$ \\
\hline
\end{tabular}


All of the morphs discussed above fall into one of the categories in Table 28. The categories can be interpreted as representing distinct morphs that occur separately or together, but on separate plants, in the part of the species population examined during the present study. Oogonia and oospores representing each of the five morphs are illustrated in Figure 40.

The extent to which such morphs can be interpreted will depend on further collecting and analysis of specimens. The data presented here offer only a preliminary indication of certain tendencies occurring within the species. These findings do, however, suggest that greater care be taken in the collection and analysis of the various gametangial elements. This is especially true when gametangia are collected in large numbers without regard to precise vegetative type or possible segregation of gametangial types. Measurements made on samples taken in such a manner show a very wide range in size of the various structures and would, therefore, mask any polymorphic tendencies that might occur in a population.

A chromosome number of 28 was determined for specimens from collections $62-4-26-5,62-4-27-8,64-9-3-3,64-9-4-1$, and 64-9-9-4. However, limited observations on specimens from collection 64-9-9-2 revealed 42 chromosomes. Recent cytological studies have reported 28 chromosomes for the species (Hotchkiss, 1958; Sasaki, 1960; Tindall and Sawa, 1964). The same number has been observed in the species from Kentucky and Indiana (Hotchkiss, unpublished). A chromosome number of 42 has not been previously reported for the species, but TindaIl and Sawa (1964) reported that number for the very closely related species, . delicatula. However, specimens of collection 64-9-9-2 did not vary from other specimens of $\underline{\mathrm{C}}$. globularis from the study area.

DISCUSSION: Chara aspera, $\underline{C}$. Ieptosperma, and $\underline{C}$. Globularis form a group of closely related species occurring in the study area. The close 
relationship of these species is illustrated by their treatment as a single species (‥ globularis) by Wood (1962). A comparison of the descriptions and illustrations of these species included here also reveals their marked similarities. However, each species is easily distinguished in the study area. Chara leptosperma occupies an internediate position between $\underline{\mathrm{C}}$. aspera and $\underline{C}$. globularis. This is especially evident in respect to numbers of branchlet segments and lengths of stipulodes and spine cells. Gametangial and oospore morphology does not confirm this assumption but vegetative morphology appears to be the more important criterion for determining relationships. The marked contrast in oospore morphology of $\underline{\mathrm{C}}$. leptosperma further distinguishes the three forms.

One other species, $\underline{\text {. }}$ delicatula Ag., reported from North America but not from the study area also belongs to this species group. This species was also included under C. globularis by Wood (loc. cit.). On the basis of vegatative morphology $\underline{\mathrm{C}}$. delicatula appears to occupy an intermediate position between $\underline{\mathrm{C}}$. aspera and $\underline{\mathrm{C}}$. globularis, thus being situated alongside $\underline{\text {. }}$ leptosperma. Chara delicatula and $\underline{\text { C. Ieptosperma }}$ show marked similarities in various vegetative characters. However, the former species is readily distinguished by its rather large dark brown to black oospores as compared with the relatively small golden brown oospores of $\underline{\mathrm{C}}$. leptosperma. The precise relationships between the four species cannot be concluded at this time but it appears that $\underline{\mathrm{C}}$. aspera, $\underline{\mathrm{C}}$. Ieptosperma, and $\underline{\text {. }}$ globularis of the present study represent the products of three independent lines of evolution. Therefore, it is concluded that until further data are available they should be maintained as separate species. 


\section{$-183-$ \\ CHARA SEJUNCTA A. Br.}

Figure 42

Chara sejuncta Braun (1845:264).

C. compacta Robinson (1906:297).

C. zeylanica var. sejuncta Wood (1962:11).

LITHRATURE FOR THE STUDY AREA: Allen (1894), Robinson (1906), H. and J. Groves (1911), and Horn af Rantzien (1950).

DESCRIPTION OF SPECIMENS: (including 5 mature plants from collection 61-9-3-2): Plants monoecious but male and female gametangia at different branchlet nodes, to $45 \mathrm{~cm}$ high, medium green, not incrusted with lime. Main axes to $540 \mu$ in diameter; cortex triplostichous, primary and secondary series ca. equal in width, spine cells developed, 85-430 $\mu$ long, acuminate, sometimes decidous. Stipulodes diplostephanous; upper tier 560-740 $\mu$ long, acuminate; lower tier 250-325 $\mu$ long, acuminate. Branchlets straight or slightly curved, 9-10 in a whorl, $1.7-3.6 \mathrm{~cm}$ long, 345-390 $\mu$ in diameter at lst corticated segment, narrowing considerably toward distal end, 1/3$11 / 3 \mathrm{X}$ internode length; consisting of 15-17 segments of which the basal one and terminal one are uncorticated; basal segment shorter than upper stipulodes, 400-700 $\mu$ long; terminal segment 300-430 $\mu$ Iong, acuminate. Bract cells well developed at fertile nodes; anteriors 2, 400-1075 $\mu$ long, acuminate; posteriors (including laterals) 5, shorter than anteriors, acuminate. Bracteoles (associated with oogonium only) 2, to $1200 \mu$ long, acuminate. Gametangia sejoined, at $2 \mathrm{nd}-6 \mathrm{th}$ ( $-7 \mathrm{th}$ ) branchlet nodes (not observed at Ist node). Oogonia ( $N=12)$ solitary, (989-) 1042 $\pm 12.1(-1118)$ $\mu$ long, (515-) $553 \pm 8.9(-600) \mu$ wide; coronulae tight or slightly spreading, (180-) $192 \pm 3.2(-210) \mu$ high, (225-) $241 \pm 4.1(-270) \mu$ wide. Oospores $(\mathrm{N}=20)$ dark brown to black, (585-) $636 \pm 5.7(-690) \mu$ Iong, (360-) 401 $\pm 6.9(-450) \mu$ wide; striae of 10-11 ridges; D.E.A. ( $N=3$ ) 54-61 $\mu$; membrane 
Fig. 42. Chara sejuncta $(61-9-3-2)$. A. Whorl of mature branchlets (all branchlets similarly corticated), X 5. B. Mature oogonium with coronula; also showing outline of nature oospore, X 66. C. Habit sketch of mature plant, X $1 / 2$. 


$$
y_{2}
$$


covered with closely arranged granules, ca. $1 \mathrm{u}$ in diameter at base and 1-2 u high. Antheridia $(N=20)$ solitary, (375-) $416-4.0(-435)$ u in diameter, 8-scutate.

SPECIMENS EXAMINED: TEXAS: (61-9-3-2) Shallow roadside ditch, 3 mi. N Cleveland, U.S. Hwy 59, Liberty Co., Texas, D. Tindall, A. Hotchkiss, and R. Goodyear, Sept. 3, 1961.

Nearly identical specimens of Chara sejuncta have been examined from Dare County, North Carolina, Meade County, Kentucky, Union County, Tennessee, and Douglas County, Kansas (in herb., Univ. of Louisville).

TYPE LOCALITY: Brazil (Braun, 1845 vide Hom af Rantzien, 1950). DISTRIBUTION: Chara sejuncta is a common species in various regions of North America, South America, and the West Indies (Horn af Rantzien, 1950; Wood and Imahori, 1959). Records of the species in North America include those from "New England" (Braun and Nordstedt, 1882), Massachusetts (Robinson, 1906), New York (Allen, 1894; Wood and Muenscher, 1956), North Carolina (present study, Wood, 1947), Indiana (Daily, 1953), Illinois (Braun and Nordstedt, 1882), Minnesota (Robinson, 1906), Missouri (Braun and Nordstedt, 1882), Kentucky (Hotchkiss, 1958; Geiling and Krumholz, 1964), Tennessee (present study), Alabama (Robinson, 1906), Nebraska (Daily, 1944), Kansas (present study), Oklahoma (Proctor, unpublished, Comanche and McCurtain Counties), Texas (present study; Proctor, unpublished, Archer, Washington, and Grimes Counties), Arizona (Hevly, 1961, Pima Co.), and Mexico (Allen, 1894; Robinson, 1906; see under varieties). South American and West Indian countries from which the species has been recorded include Columbia, Brazil, Bolivia, Puerto Rico, Guadeloupe, and Barbados (Hom af Rantzien, 1950).

The known distribution of Chara sejuncta in the study area, including Proctor's unpublished records, is shown in Figure 43. Since collections 


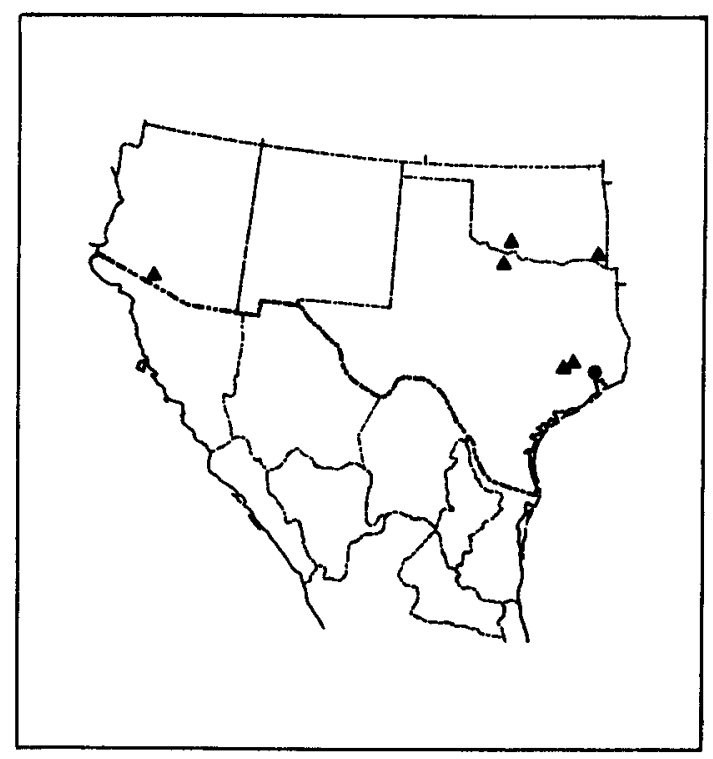

Fig. 43. Distribution of Chara sejuncta in the study area; locallty examined during the present study, $\Delta$ localities reported in the literature. 
of this species are quite limited, no distinct pattern of distribution can be determined in the study area.

BCOLOGY: Physicochemical features of the habitats.-Various data from habitats supporting Chara sejuncta in North Carolina, Kentucky, and Texas are included in Table 29. All of the habitats were basically similar in respect to physical features, being characterized by clear, shallow, and open waters, and sand and/or silt substrates. All of the temperature and chemical data from the various habitats do not represent optimal conditions for the maintenance of Chara sejuncta. The species was sparse but well developed and in good condition in the North Carolina and Texas localities. The species formed large beds in the three sinkhole ponds in Meade County, Kentucky. On July 15, 1960, the species was observed in a young but well-developed state in Pond 6 (Geiling and Krumholz, 1964). It continued to flourish through August, September, and early October. On October 23, 1960, the species had nearly disappeared from the pond. of the factors recorded, temperature displayed the greatest contrast in comparison with previous samples from the pond. Chara sejuncta was observed in Pond 2 on October 9, 1961, at which time the water was quite cold and the plants were beginning to break up. Pond I displayed a large

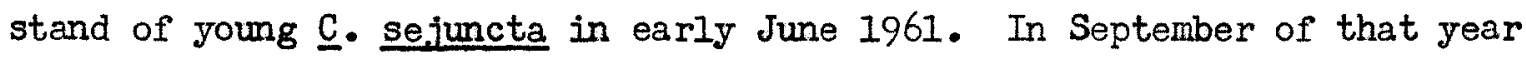
the plants were well developed and flourishing but by October 17 only small fragments of tre Chara were found. Although the temperature recorded on the latter date was not extremely low, it is reasonable to assume, on the basis of recordings from the other ponds, that lower temperatures had been reached prior to the October 17 sample.

Based on all available data, Chara sejuncta appears to require shallow, warm, and open waters which are low in alkalinity. Variations in $\mathrm{pH}$ and carbon dioxide content of the water appears to be of little significance with regard to the occurrence and abundance of the species. 
Table 29. Physicochemical features of habitats supporting Chara sejuncta.

\begin{tabular}{|c|c|c|c|c|c|c|c|c|c|c|c|}
\hline Specimens & Locality & Habitat & Substrate & Depth & $\begin{array}{l}\text { Tur- } \\
\text { bidity }\end{array}$ & Iight & $\begin{array}{l}\text { Tempe: } \\
\text { air }\end{array}$ & $\begin{array}{l}\text { rature } \\
\text { water }\end{array}$ & $\mathrm{pH}$ & Alk. & $\mathrm{CO}_{2}$ \\
\hline $61-10-7-3$ & $\begin{array}{l}\text { North } \\
\text { Carolina }\end{array}$ & pond & sand & 0.35 & $t$ & open & 22.0 & 23.0 & 7.6 & 25 & 1.0 \\
\hline $60-7-15$ & Kentucky & pond 6 & sand-silt & 0.40 & 0 & open & - & - & 6.8 & 51 & 16.0 \\
\hline $60-9-8$ & $"$ & n $n$ & $n$ & $"$ & $"$ & $"$ & - & $32.8-24.4 *$ & 6.4 & 48 & 38.0 \\
\hline $60-10-8$ & $n$ & " & $"$ & $"$ & $n$ & $"$ & - & $35.6-23.3$ & 7.0 & 51 & 10.0 \\
\hline $60-10-23$ & $"$ & $" 1 "$ & $"$ & $n$ & $n$ & $"$ & - & $28.5-7.8$ & 7.0 & 70 & 13.5 \\
\hline $61-6-6-1$ & Kentucky & pond 1 & silt-sand & 0.50 & 0 & open & - & 31.0 & 8.3 & 60 & 0.0 \\
\hline $61-9-23-2$ & $"$ & $" \quad "$ & $n$ & $"$ & $"$ & $"$ & 33.0 & 28.0 & 9.62 & 43 & 0.0 \\
\hline $61-10-17-1$ & $"$ & " " & $"$ & $n$ & $"$ & $n$ & 25.0 & 19.0 & 10.2 & 42 & 0.0 \\
\hline $61-10-9-1$ & Kentucky & pond 2 & sand-silt & 0.30 & 0 & open & - & 11.0 & 8.4 & 26 & 0.0 \\
\hline $61-9-3-2$ & Texas & ditch & $\begin{array}{l}\text { silt- } \\
\text { organic }\end{array}$ & $\begin{array}{l}0.30- \\
1.0\end{array}$ & 0 & open & 31.0 & 31.0 & 7.8 & 40 & 1.5 \\
\hline
\end{tabular}

*maximum-minimum water temperatures of pond 6 for periods between samples. 
Plant communities.--The North Carolina locality supported small tufts of Nitella tenuissima and Chara sejuncta sparsely distributed throughout a large stand of $\underline{\mathrm{C}}$. fibrosa. Nuphar $\mathrm{sp}$. was the most abundant vascular plant in this habitat but was not directly associated with the charophytes. Chara sejuncta formed dense stands in limited areas of several sinkhole ponds in Meade County, Kentucky. Ceratophyllum demersum and Potamogeton diversifolius commonly occurred in the same ponds (Geiling and Krumholz, 1964). Chara sejuncta occurred as isolated plants sparsely distributed throughout a large stand of $\underline{C}$. hydropitys in the Texas locality. MORPHOLOGY, CYTOLOGY, AND TAXONOMY: Only specimens from the Texas locality were examined in detail. These specimens are very uniform in all morphological features (description). Compared with specimens from North Carolina, Kentucky, Tennessee, and Kansas, the Texas plants displayed more numerous branchlet segments but were otherwise quite similar.

Hotchkiss (1958, 1963) reported a chromosome number of 14 for Chara sefuncta from Meade County, Kentucky. The same number has been determined for the species from Rhode Island, North Carolina, (from several localities including that of collection 61-10-7-3), Tennessee (61-6-15-1), Kansas $(60-8-13-4)$, Oklahoma (from two localities [see above] supplied by $V$. Proctor), and Texas (specimens from three localities [see above] supplied by V. Proctor, and from collection 61-9-3-2) (Hotchkiss, unpublished). The specimens described above represent an attenuated form of typical Chara sejuncta. In comparison with the typical form, the present specimens have more numerous branchlet segments, slightly smaller oospores, and somewhat larger antheridia. 
Figure 44

Chara zeylanica var. sejuncta fo drouetii Wood (1962:12), Wood and Imahori (1964, Icon, 102), Wood and Imahori (1965:242)。 C. drouetii (Wood) Wood (Wood and Inahori, 1965:768).

DESCRIPTION OF SPECIMENS (including 5 mature plants from collection 61-9-9-5): Plants monoecious but male and female gametangia at different branchlet nodes, to $15 \mathrm{~cm}$ high, small and appearing delicate, tufted, medium green (grayish before lime was removed), heavily incrusted with lime. Main axes 225-300 $\mu$ in diameter; cortex triplostichous, primary and secondary series ca. equal in width; spine cells all reduced, globular or slightly flattened horizontally. Stipulodes diplostephanous, well developed and neatly arranged; upper tier 225-360 $\mu$ long, acuminate; lower tier 165-285 p long, acuminate. Branchlets straight or slightly curved, 8-9 in a whorl, 3-5 (-9) mm long, 1/3-2/3 $\mathrm{X}$ internode length; consisting of 6-8 segments of which the basal one and terminal 1-3 (-4) are uncorticated; basal segment longer than upper stipulodes, (500-) ca. 700 (-940) $\mu$ long; terminal segment short and acuminate; penultimate segment variable, up to $1800 \mu$ long, sometimes slightly swollen. Bract cells developed at fertile nodes; anteriors 2, 150-225 $\mu$ long, acuminate; posteriors 2-3, 75-150 $\mu$ long, longer ones acuminate. Bracteoles (associated with oogonium only) 2, 225-375 $\mu$ long, acuminate. Bractlet 1, 300-375 $\mu$ long, acuminate. Gametangia sejoined, at 1st-4th branchlet nodes. Oogonia (N-11) solitary (rarely 2 at a node), (560-) 593 $\$ 5.8$ (-622) $\mu$ long, (330-) $342 \pm 5.5(-360) \mu$ wide; coronulae spreading, (45-) $63 \pm 3.6(-75) \mu \mathrm{high},(120-) 128 \pm 2.4(-142) \mu$ wide. Oospores (N=25) dark brown, (335-) 362 $\pm 3.8(-390) \mu$ long, (210-) 232 $\pm 2.1(-255) \mu$ wide; striae of 10-12 low but distinct ridges; D.E.A. $(\mathrm{N}=16)(29-) 34 \pm 0.8(-40) \mu$; 
Fig. 44. Chara drouetii $(61-9-9-5)$. A. Details of axial cortex and stipulodes, $X$ 66. B. Habit sketch of mature plant, $X I / 2$. C. Mature oogonium with coronula; also showing outline of mature oospore, X 66. D. Nature branchlets, X 25. 


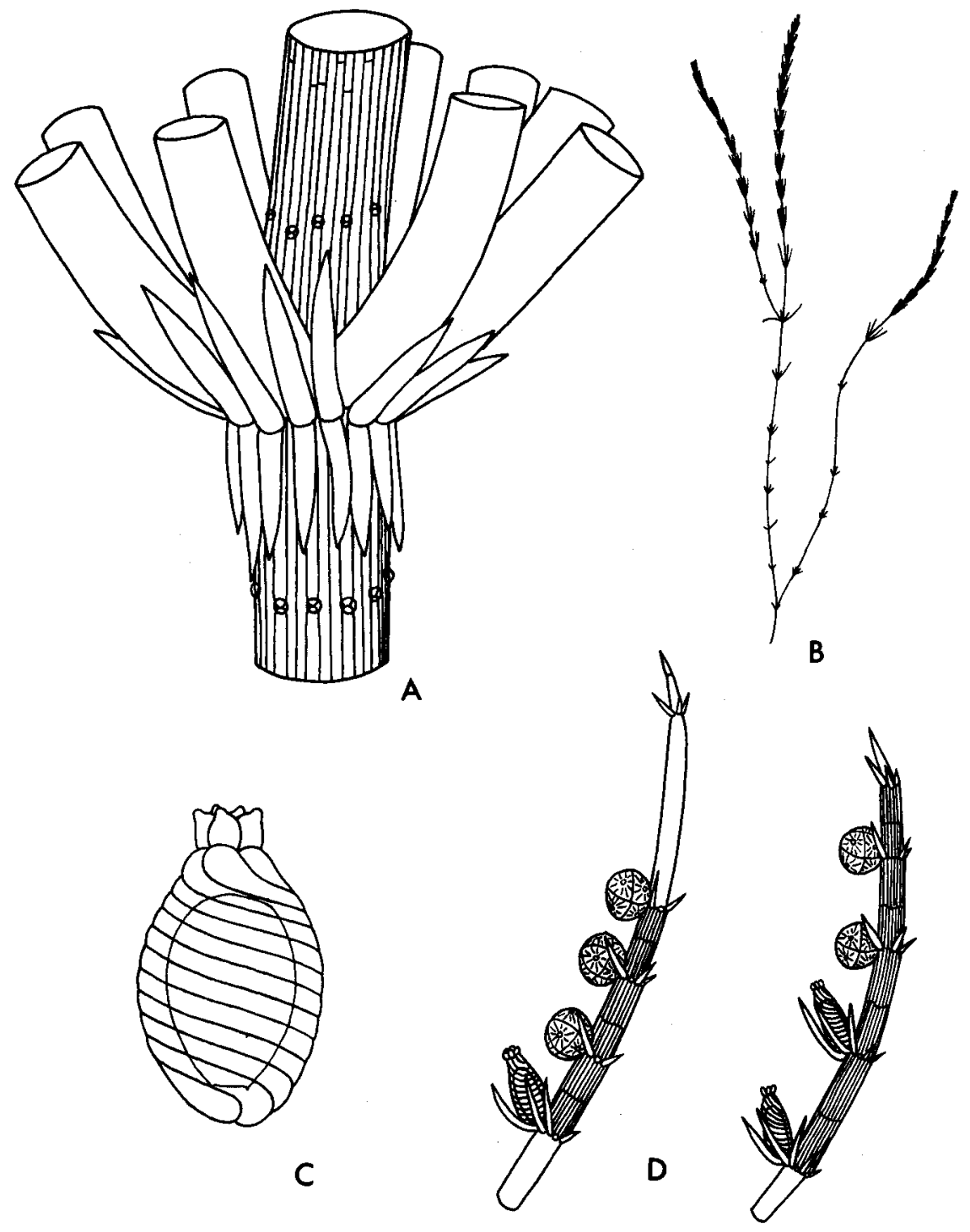


membrane smooth to very finely granulate. Antheridia (N=25) solitary (rarely 2 at a node), (240-) 269 $\pm 2.9(-292) \mu$ in diameter, 8-scutate.

SPECIMENS EXAMINED: SAN LUIS POTOSI: (61-9-9-5) Small limestone stream flowing W, $31 \mathrm{mi}$. S Cd. Mante, Mex. Hwy 85, San Luis Potosi, Mexico, D. Tindall, A. Hotchkiss, and R. Goodyear, Sept. 9, 1961.

TYPE IOCALITY: "In shallow water of pond at base of dunes, Urubri, Municipio de Fortaleza, Ceara, Brazil..."; collected by F. Drouet, August 1, 1935 (Wood, 1962).

DISTRIBUTION: The type locality and the single locality in Mexico respresent the known distribution of Chara drouetii. Since the two collections are widely separated, the form can be expected to display a more conmon occurrence in North, Central, and South America, at least in the tropical regions.

ECOLOGY: Small compact tufts of Chara drouetii occurred in shallow water near the banks of a pool in a slowly flowing limestone stream. The water was characterized by the following conditions: temperature $30 \mathrm{c}$ (air temp. $34 \mathrm{C}$ ), $\mathrm{pH} 7.85$, alkalinity $193 \mathrm{mg} / 1$, and free carbon dioxide ca. $5 \mathrm{mg} /$. The species formed a relatively insignificant part of a well-developed charophyte community comprised of $\underline{\text {. }}$ zevlanica, Nitella hyalina, ‥ acuminata, N. tenuissima, and N. oligospira (see N. tenuissima). MORPHOLOGY, CYTOLOGY, AND TAXONOMY: Mature specimens of Chara drouetii from the Mexican locality have very uniform morphological features (description, Fig. 4h). The specimens are nearly identical to the HOLOTYPE described by Wood but the Mexican specimens possess 8 -scutate antheridia, whereas the type specimen shows 4-scutate antheridia (Wood and Imahori, 1964, 1964). Wood and Imahori also reported 4-scutate antheridia in several other sejoined members of the $\underline{C}$. zeylanica complex. These findings are contrary to my observations of only 8-scutate antheridia on numerous 
specimens of $\underline{\underline{C}}$. sejuncta from various parts of North America (including the study area). Griffin and Proctor (1964) concluded that certain specimens of $\underline{C}$. zeylanica could consistently be distinguished on the basis of antheridial shield number (4- or 8-scutate). However, the taxonomic significance to be attributed to this character has not been determined.

A chromosome number of 14 was determined for specimens from the single collection in the study area. This number is characteristic of all other members of the $\underline{\mathrm{C}}$. zeylanica complex with sejoined gametangia thus far counted from North America.

Taxonomically, the present specimens can be referred only to the taxon described by Wood (1962) and Wood and Imahori (1964, 1965) as Chara zeylanica var. sejuncta f. drouetii. Wood and Imahori (1965) presented an appendix (Microspecies Appendix) to their rather drastic revision of the Characea, in which all forma described in the revision were raised to species rank. Thus $\underline{C}$. drouetii is a validly published species. It should be pointed out at this time that the appendix presented by Wood and Imahori results in weakening the main arguments of the revision in general. 


\section{CHARA CIENEGAENSIS sp. nov.}

Figure 45

DESCRIPTION OF SPECIMENS (including the HOLOTYPE AND 4 ISOTYPES 60-8-23-1, and 3 specimens from each of the following collections: $60-8-18-1 B, 60-8-21-1 B, 60-8-20-2$, and $60-8-21-1 B):$ Plantae monoeciae, 7-19 cm altae. Axes -700 $\mu$ in diam.; triplosticha, tylacantha; diplostephana. Verticillorum ramuli (9-) 10-11 (-12), (1.0) 1.5-2.0 (-3.1) cm Iongi, segmenti (5-) 6-7 (-8), gumopodi, 0-2 (-4) corticati. Gametangia sejuncta. Oogonia solitaria, 730-754 $\mu$ Ionga, $423-438 \mu$ lata; coronula $120-136 \mu$ alta, $168-180 \mu$ lata. Oosporae 390-440 $\mu$ longae, 275-335 $\mu$ latae; striae 10-11; membrana granulata. Antheridia 245-307 $\mu$ in diam., 8-scutata.

Plants monoecious but male and female gametangia at different branchlet nodes (very rarely at same node), 7-19 cm high, spinescent, light to medium green, heavily incrusted with lime. Main axes to $700 \mu$ in diameter; cortex triplostichous, primary series much more prominent than secondary series (tylacanthous); spine cenns abundant, $340-515 \mu$ long, acuminate. Stipulodes diplostephanous, well developed; upper tier to $946 \mu$ long, acuminate; lower tier to 645 (-817) $\mu$ Iong, acuminate. Branchlets straight or slightly curved, (9-) 10-11 (-12) in a whorl, (1.0-) $1.5-2.0(-3.1) \mathrm{cm}$ Iong, usually $1-11 / 2 \mathrm{X}$ internode length; consisting of (5-) 6-7 (-8) segments of which the basal one is always uncorticated, next $1-2(-3$, rarely 4$)$ may be corticated, frequently none corticated; basal segment usually much longer than upper stipulodes; terminal segment short and acuminate, usually subtended by a whorl of bract cells. Bract cells distinctly verticillate and well developed; anteriors 2 (but laterals closely approaching position of anteriors), 645-865 $\mu$ long, acuminate; laterals 4, 430-735 $\mu$ long, acuminate, 
Fig. 45. Chara cienegaensis. A. Mature fertile branchlet (60-8-23-1), X 10. B. Habit sketch of mature plant $(60-8-23-1), X 1 / 2$. C. Mature oogonium with coronula; also showing outline of mature oospore (60-819-1), X 66. D. Mature sterile branchlet (60-8-23-1), X 10. E. Details of stipulodes and axial cortex (60-8-23-1), X 25. 


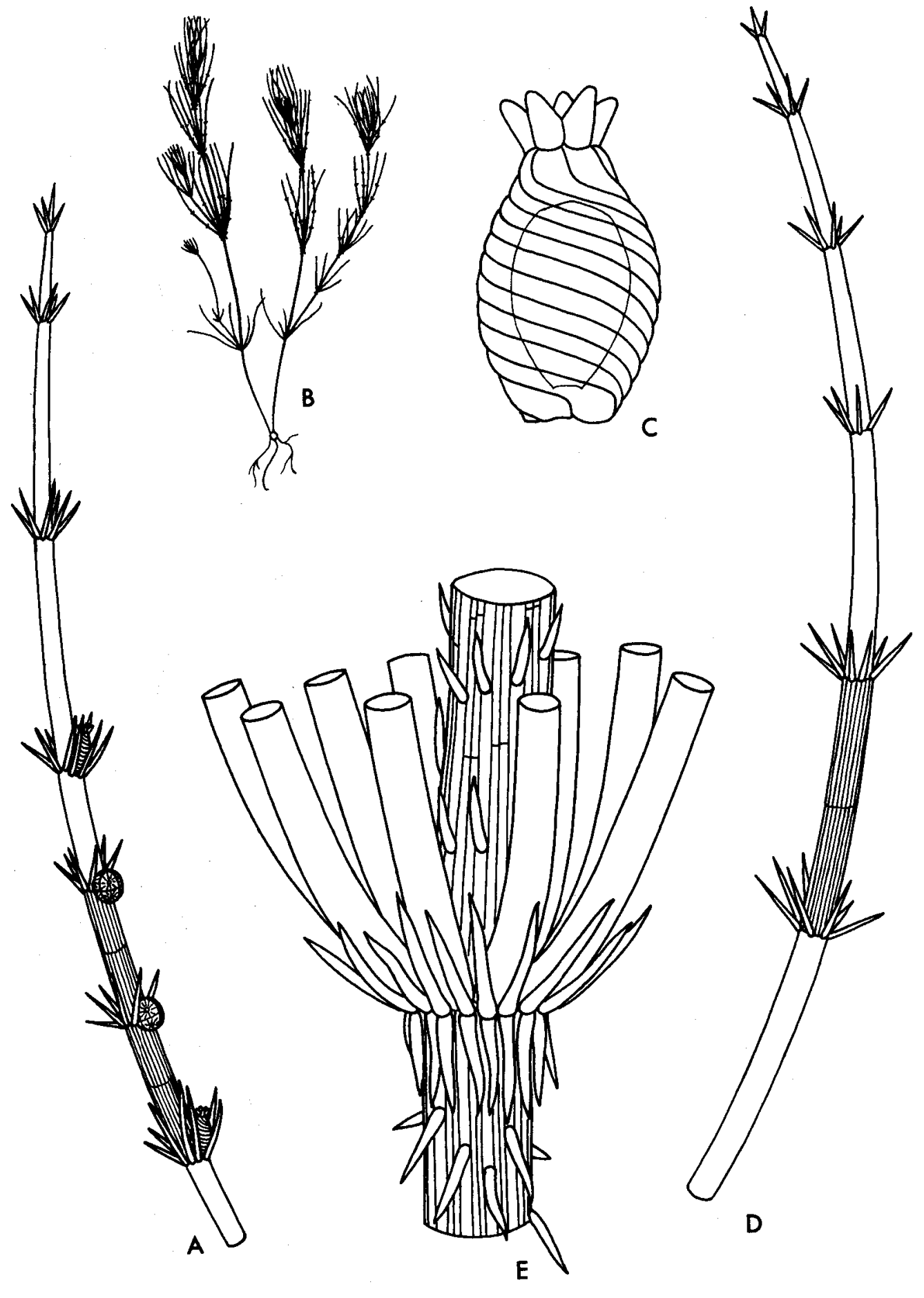


posterior 1, 248-478 $\mu$ long, blunt or acuminate. Bracteoles (associated with oogonium only) 2, 559-775 $\mu$ long, acuminate. Bractlet 1, 516-820 $\mu$ long, acuminate. Gametangia sejoined (very rarely conjoined), at 1st4th branchlet nodes. Oogonia ( $N=2$ ) solitary, 730-745 $\mu$ long, 423-438 $\mu$ wide; coronulae spreading, $120-136 \mu$ high, $168-180 \mu$ wide. Oospores $(N=20)$ medium

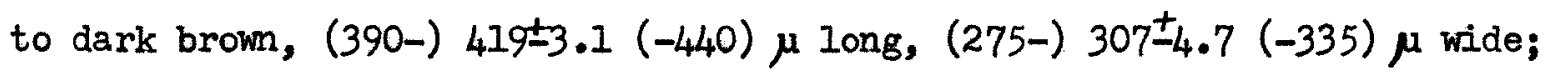
striae of 10-11 low but prominent ridges; D.E.A. (36-) $43 \pm 0.9(-50) \mu$; membrane somewhat irregular but usually coarsely granulate. Antheridia $(N=10)$ solitary, $(245-) 283 \pm 6.8(-307) \mu$ in diameter, 8-scutate.

SPECIMBNS EXAMINED: COAHUILA: (TIPE 60-8-23-1) In one of a series of lagunas, known collectively as Altimira, $10 \mathrm{mi}$. S, 3 mi. E Cuatro Cienegas, Coahuila, Mexico, D. Tindall, W. Minckley and J. Craddock, Aug. 23, 1960. (60-8-18-1B) Ia Angostura Canal, $1.6 \mathrm{mi} s$ Cuatro Dienegas, Coahuila, Mexico, D. Tindall, W. Minckley and J. Craddock, Aug. 18, 1960. (60-8-19-1) Ia Angostura Canal, $4.1 \mathrm{mi}$. SSW Cuatro Cienegas, Coahuila, Mexico, D. Tindall, W. Minckley and J. Craddock, Aug. 19, 1960. (60-8-202) Slow flowing stream, just before emptying into Posos de los Cueros, 11.1 mi. SSW Cuatro Cienegas, Coahuila, Mexico, D. Tindall, W. Minckley and J. Craddock, Aug. 20, 1960. (60-8-21-1B) Saca del Fuente Canal, 3.3 mi. S Cuatro Cienegas, Coahuila, Mexico, D. Tindall, W. Minckley and J. Craddock, Aug. 21, 1960.

DISTRIBUTION: Chara cienegaensis is known only from the intermontane basin of Cuatro Cienegas (hence the name) in central Coahuila, Mexico. BCOLOGY: The species formed an extensive bed in the laguna at Altimira. Utricularia sp. comprised the only significant submerged vascular flora, whereas Typha latifolia was abundant around the shallow edge of the laguna. All of the flowing water habitats were characterized by cool waters and marly substrates. Other plants directly associated 


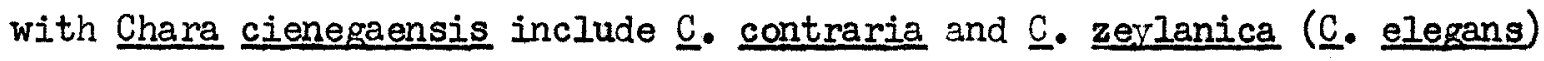
in Saca del Fuente Canal and C. contraria in La Angostura Canal. MORPHOLOGY, CYTOLOGY, AND TAXONOMY: Only minor variations were observed among specimens of Chara cienegaensis. These include degree of fertility, number of corticated branchlet segments, and general habit. Plants which showed a greater degree of fertility also displayed more numerous corticated branchlet segments. Variations in habit were limited to height of plants and length of branchlets. The compact nature of some plants resulted in a conspicuous display of spine cells.

A chromosome number of 14 was determined for specimens from each collection of Chara cienegaensis. This number agrees with that found in the closely related $\underline{\text { C. sejuncta }}$ and $\underline{\mathrm{C}}$. drouetii.

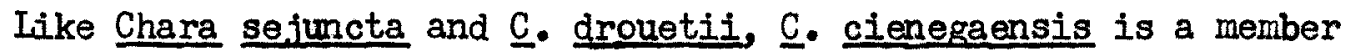
of the $\underline{\mathrm{C}}$. zerlanica complex with sejoined gametangia. Although $\underline{\mathrm{C}}$. cienegaensis is characterized by sejoined gametangia, it shows closer relationships to forms referable to $\underline{\mathrm{C}}$. inconstans (a member of the $\underline{\mathrm{C}}$. zeylanica complex with conjoined gametangia) than it does to $\underline{C}$. sejuncta. Thus, in concurring with previous works which maintain the sejoined forms as separate species, it has been necessary to establish the new species. Both $\underline{\mathrm{C}}$. cienegaensis and $\underline{\mathrm{C}}$. inconstans are characterized by uncorticated or slightly corticated branchlets, well developed spine cells and stipulodes, and distinctly tylacanthous cortex on their axes. Chara cienegaensis is distinguished by its sejoined gametangia, 8-scutate antheridia, and chromosome number of $\mathbb{1}_{4}$, whereas $\underline{C}$. inconstans displays conjoined gametangia, 4-scutate antheridia, and a chromosome number of 28. 
The present treatment of species of Nitella and Chara was based primarily on the work of Braun and Nordstedt (1882) but was supplemented in part by the works of Allen (1882-1900), Robinson (1906), Groves and Bullock-Webster (1920, 1924), Zaneveld (1940), Daily (1953), Allen (1954), and Wood and Imahori (1964, 1965). All of these authors followed a similar approach to the problem of delimiting species, although their respective interpretations of variability differed considerably. None of these authors stated directly his concept of species but it is apparent that these treatments were based on the typological or morphological species concept. The present state of our knowledge of this group necessitates the continued following of this concept. Not until experimental study is carried out on representatives of all sections of the various genera will we be able to apply the genetic and biologic species concepts to members of the Characeae.

Ecological studies of the Characea in the study area had not been carried out prior to the present study. The ecological data presented in the text usually represent results obtained from single samples made at the time of particular collections. The incompleteness of such sampling permits anly general interpretation of the results at this time. The data are intended to represent a starting point for more refined ecological studies.

Nitella.-Prior to the present study less than 30 collections of Nitella representing 16 species had been reported from the study area (Wood, 1948; Horn af Rantzien, 1950; Hevly, 1961). Eighty-three additional collections representing 9 species are reported in the present study. Collections from adjacent areas are also reported. Three species are reported from the area for the first time, namely $\underline{\mathbb{N}}$. hotchkissii sp. nov., 
N. mirabilis, and ․ tenuissima (except for var. compacta). The remaining species reported here, N. missouriensis, N. acuminata, ‥ clavata, N. oligospira, N. hyalina, and those that refer to the N. gracilis species group, are considered to represent 19 species or varieties previously described or reported from western North America, Central America, and northern South America. Much of this synonymy was suggested by earlier workers but several new combinations have resulted from this study. Species previously reported from the area but not treated here include $\underline{N}$. annularis, $\underline{N}$. asagrayana, and N. pygmaea which are known only from their respective type localities in northern Mexico (reviewed by Wood, 1948; Horn af Rantzien, 1950); ‥ praelonga which is known only from single localities in South Carolina, Texas, and Vera Cruz (Wood and Imahori, 1965); and N. mucronata which is known from single localities in Texas, New Mexico, and Mexico (Wood, 1948). The latter species has been reported from Burope, Africa, Asia, South America, and elsewhere in North America (Wood and Imahori, 1959).

The genus Nitella has been variously subdivided in the past, (Braun and Nordstedt, 1882; Groves and Bullock-Webster, 1920; Groves, 1935; Zaneveld, 1940; Allen, 1954; Wood, 1962). The ma Jor subdivisions were based originally on the number of cells in the ultimate rays of the branchlets, i.e. Section 1. Anarthrodactylae (ultimate rays one-celled), Section 2. Arthrodactylae (ultimate rays two-or more-celled, Groves and Bullock-Webster, 1950). However, Groves (1935) proposed a system separating the genus on the basis of presence or absence of accessory branchlets (Sections Homoeoclemae and Heteroclemae respectively). Both systems have failed to produce completely natural arrangements of species. Wood (1962) proposed intricate and for the most part quite natural subdivisions of the genus based on three subgenera. 
According to Wood's subgeneric classification, Nitella missouriensis, N. mirabilis, ‥ hotchkissii, ‥ acuminata, and ‥ clavata of the present study would be included under subgenus Nitella. However, the data presented here indicate that there are two distinct parallel lines comprising this group each of which should receive separate subgeneric status. Nitella missouriensis, N. mirabilis, and N. hotchkissii of the present study together with $\underline{N}$. opaca, ․ syncarpa, and N. flexilis form a continuous series characterized by 1-2-furcate branchlets, blunt to acuminate dactyls, oogonia with deciduous coronulae, oospores ranging from 225-575 $\mu$ long, antheridia ranging from $500-945 \mu$ in diameter, and chromosome numbers of 6 and 12 (the latter number being characteristic of $\underline{N}$. flexilis only). Species including $\underline{N}$. acuminata (consisting of numerous subspecies, varieties, and forma, some of which may represent species), ‥ clavata and probably ․ stuartii, $\underline{N}$. macounii, and N. allenii form a distinct but somewhat broken series characterized by 1-2-furcate branchlets, distinctly acuminate dactyls, oogonia with persistent coronulae, ,oospores ranging from ca. 200 to $380 \mu$ long, antheridia ranging from ca. 190 to $510 \mu$ in diameter, and chromosome numbers of 9 or 18 ( $n=9$ is characteristic of $\underline{N}$. acuminata from the study area, whereas $\mathrm{n}=18$ has been reported for that species from Kentucky, North Carolina, Japan, and India). Chromosome numbers are not available for other members of this series. Marked differences in vegetative morphology are not always apparent between the two groups but gametangial characteristics in association with particular vegetative types readily separate them. The distinctly contrasting series of chromosome numbers serves as one major criterion for separating the two groups at the subgeneric level. The chromosomes of the two groups also differ markedly in size. Species of the $\underline{N}$. missouriensis-flexilis series display relatively large chromosomes ranging from ca. $2-11 \mu$ long, whereas, ‥ acuminata and $\underline{N}$. clavata display small chromosomes 
ranging from $\mathrm{ca} .1 .5-5 \mu$ in length. Further distinction between the two groups is demonstrated by marked differences in their respective axial nodal structure (Sawa, unpublished). It is, therefore, concluded that subgenus Nitella should be limited to species of the $\underline{N}$. missouriensisflexilis series and that a new subgenus be established to include species of the ․ acuminata-clavata series. The actual naming of the subgenus must await examination of all species that are to be included.

Wood designated two additional subgenera, Hyella including species with 2-or more celled dactyle without mucros, and Tieffallenia including species with 2-or more celled dactyls but with mucros. Species of the subgenus Hyella were not examined during this study but several specimens of Taxon A of the Nitella gracilis species group displayed abnormal dactyls which superficially resemble those of species belonging to the subgenus. Based on Wood's treatment the remaining species examined during the present study, including $\underline{N}_{0}$ oligospira, N. tenuissima, Taxon $A$ and Taxon B of the N. gracilis species group, and N. hyalina, belong to the subgenus Tieffallenia. At present, there is no conclusive evidence supporting further subdivision of this group at the subgeneric level. However, observations on the latter mentioned species and their close relatives from elsewhere in North America

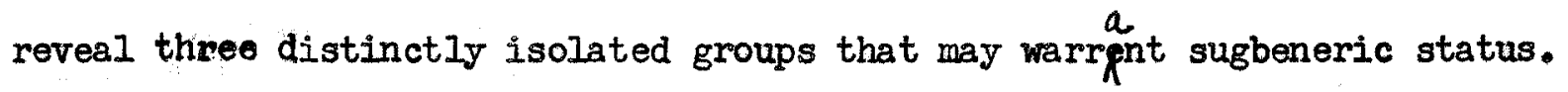
These groups and their representatives include (1) N. oligospira, N. mucronata, and N. megacarpa; (2) N. gracilis, ‥ tenuissima, No transilis, and N. intermedia; and (3) N. hyalina. These groups represent Sections Tieffallenia, Gioallenia, and Decandollea respectively of subgenus Tieffallenia (Wood, 1962), Group 1 and 2 appear to represent independent parallel evolutionary lines.

For the purpose of discussion, the series or groups of species of Nitella reported here will be referred to as species groups. A species group is defined as a group of closely related species, usually with partially 
overlapping ranges (Mayr, 1964). The names which are presently applied to these groups are the oldest named species representing the particular groups in North America.

Nitella missouriensis, № mirabilis, and № hotchkissii are members of the N. flexilis species group. Other representatives of this group known to occur in North America include $\mathbb{N}$. flexilis and N. opaca. The current interpretation of N. missouriensis follows that of Allen (1954) and Daily (in Hevly, 1961) in that N. missouriensis, N. montana, N. blankinshipii, and $\underline{N}$. occidentalis are placed under $\underline{\mathrm{N}}$. acuminata. This treatment emphasizes the close similarities of the $\underline{N}_{0}$ flexilis and $\underline{N}$. acuminata species groups. However, the morphological and cytological data presented here show conclusively that $\underline{N}$. missouriensis is distinctly related to members of the N. flexilis species group. In fact, N. missouriensis shows marked tendencies toward intergradation with $\mathbb{N}$. opaca. The latter species has been reported from single localities in Texas, Nevada, Utah, California, Oregon, Montana, and Mexico (Braun and Nordstedt, 1882; Allen, 1892) which is approximately the samo range as that occupied by $\mathrm{N}$. missouriensis. Although I have not examined the specimens of $\underline{\mathrm{N}}$ opaca from the above localities, the literature suggests that the specimens may well represent forms actually referable to ‥ missouriensis. No specimens were collected from the study area that could definitely be regarded as $\mathbb{N}_{0}$ opaca but forms most closely approaching that species were observed in central lowland areas including parts of Kansas, Oklahoma, and Texas. Specimens of N. missouriensis from the western highlands, including parts of Arizona and Chihuahua, were very uniform and did not show tendencies toward N. opaca. The greatest concentration of $\underline{N}$. opaca in North America appears to be in the northeastern and Great Lakes regions of the United States. The central plains may represent a zone of overlap between $N_{0}$ opaca and $N_{0}$ missouriensis. 
The Nitella missouriensis complex is further complicated by the presence of populations in Okalhoma that display characteristics somewhat intermediate

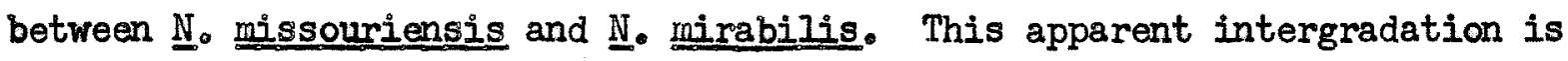
marked primarily by relative sizes of oospores and the character of dactyl apices. Such intergradation may be only superficial, resulting from variations in environnental conditions or it may represent actual hybridization between the two species.

Prior to the present study, the known distribution of Nitella mirabilis was limited to a few widely scattered localities in Asia. The present records of the species represent a major extension of its range. This rather broad range suggests that the similarities between typical $\underline{N}$. mirabilis and the specimens described here may be only superficial.. The name, ‥ mirabilis, is currently applied since no other name is available and from a morphological standpoint the American specimens can not be completely separated from the type specimens from Asia. The present specimens do, however, appear to represent a separate subspecies which in turn may be comprised of two lesser taxa. One of the latter being characterized by rather acuminate dactyls and basal oogonia, whereas, the other displays acute or blunt dactyls and only rarely displays basal oogonia. These rather marked variations could possibly be a result of the supposed hybridization between $\underline{N}$. mirabizis and $\mathrm{N}$. missouriensis. Infraspecific names can not be applied to these variations until the entire complex is more furly understood.

Nitella missouriensis and N. mirabilis were found growing together on one occasion, but the species usually occupied somewhat contrasting environments. This was especially evident in respect to light conditions and water chemistry. Nitella missouriensis usually occurred in quiet waters which received direct sun light, whereas, N. mirabilis occurred in heavily 
shaded areas of slowly flowing streams. The latter species was observed primarily in waters characterized by high alkalinity, moderately alkaline $\mathrm{pH}$, and an abundance of free carbon dioxide. Nitella missouriensis, on the other hand, was most frequently observed in waters which were characterized by rather low alkalinity, high $\mathrm{pH}$, and negligible free carbon dioxide. Both species occurred on rather soft substrates in cool shallow waters.

The new species, Nitella hotchkissii, is closely related to $\underline{N}$. missouriensis and N. mirabilis but is readily distinguished from them by consistently 2-furcate branchlets and relatively small oospores. These characteristics are rare in the ․․ flexilis species group but it is presently

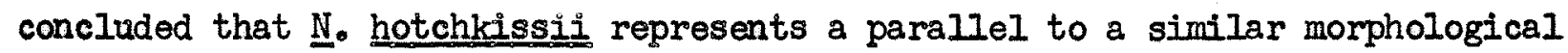
type exemplified by N. stuaritii, N. macounii, and N. allenii in the N. acuminata species group.

Specimens of Nitella acuminata examined during this study form a variable but continuous intergrading series which encompasses seven species previously described or reported from the study area. These include N. acuminata, $\mathbb{N}$. subglomerata, N. lindheimeri, N. gollmeriana, N. mexicana, ‥ subspicata, and IN. stellarig. The inclusion of N. subglomerata is intended to represent only specimens from the study area which have been referred to that species. AII of these species, except N. mexicana, in the past have been variously

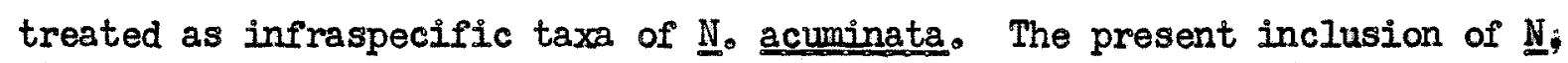
mexicana in the N. acuminata complex represents a new interpretation. Wood (1962) concluded that № mexicana was a form of №flexilis. Collections made during the present study from the vicinity of the only known locality of N. mexicana revealed plants nearly identical to the type description but they doubtlessly represent $\mathbb{N}$. acuminata as described in this study. This treatment was based primarily on the very small gametangia and oospores of typical ‥ mexicana which correspond precisely with those of the other 
members of the $\underline{N}$. acuminata complex collected in the study area. Of considerable importance also is the bact that $\underline{N}$. flexilis is not known to occur in the study area, whereas $\mathbb{N}$. acuminata is quite common. Specimens of $\underline{N}$. acuminata were also collected in the vicinity of the type localities of $\mathrm{N}$. lindheimeri and $\mathrm{N}$. stellaris, and localities reported for $\underline{\mathrm{N}}$. subglomerata. In each instance the specimens were referable to a single taxon, which is presently considered to be $\underline{N}$. acuminata. Nitella gollmeriana and $\mathbb{N}$. subspicata are included in this taxon since their distinguishing features fall well within the range of variation displayed by specimens examined during this study. The principal features characterizing the forms that were originally described as separate species were relative lengths of dactyls and presence or absence of fertile heads. These characters have proved to be of little value for distinguishing species in the N. acuminata species group. However, oospore size, membrane decoration, and size of antheridia, along with general regetative features prove to be valuable taxonomic criteria. One of the most significant characters tying together all of the specimens of $\underline{\mathbb{N}}$. acuminata collected during this study is that of chromosome number. A chromosome number of 9 was determined for specimens from all populations observed during this study. This number has not previously been reported for tile species. A chromosome number of 18 is known for the species in Kentucky (Hotchkiss, 1958), North Carolina (unpublished), Japan (Imahori and Kato, 1961; Sasaki, 1960), and India (Sarma and Khan, 1964).

The regular occurrence of $\mathbb{N}$. acuminata with 9 chromosomes in more southern regions of North America and the occurrence of nearly identical plants in Kentucky and North Carolina and with 18 chromosomes suggest that the 18-chromosome form represents a polyploid that has accompanied the northern advancement of the species. One other alternative is that the 18-chromosome form represents an allopolyploid which has resulted from 
hybridization between the 9-chromosome plants in the south and hypothetical 9-chromosome plants in the north. Cytological examination of the typically northern $\underline{N} \cdot$ glomerulifera $(=\mathbb{N}$. acuminata ssp. glomeruliffera Braun) may resolve the problem.

The second member of the $\underline{N}$. acuminata species group occurring in the study area, N. clavata, is also characterized by 18 chromosomes. However, the species is clearly distinguishable from $\underline{N}$. acuminata on the basis of general morphology. There is a possibility that $\underline{\mathbb{N}}$. clavata is comprised of two taxa, one representing the typical form and the other representing N. clavata var. inflata. It appears at this time, however, that these morphological variations result primarily from variations in environmental conditions.

Nitella acuminata and $\underline{N}$. clavata have distinctly different distribution patterns in the study area. The former species was observed only at lower altitudes of southcentral United States and in tropical regions of northeasterh Mexico. Nitella clavata appears to be limited to the western highlands and Mexican Plateau. Nitella acuminata was most frequently observed in shallow open areas of slowly flowing limestone streams. These waters were usually characterized by rather warm termerature, moderately alkaline pH (7.2-7.85), moderate alkalinity, and an abundance of free carbon dioxide. Nitella clavata occupied quite variable habitats but water conditions were similar throughout the range of the species. The waters were usually derived from spring sources and were characterized by cool temperature, moderate alkalinity, $\mathrm{pH}$ ranging from 7.6-9.4, and negligible or low free carbon dioxide.

Nitella oligospira is the only member of the N. mucronata species group observed in the study area. Nitella mucronata has been reported from single localities in New Mexico and Texas but the descriptions of these specimens are inconclusive and the localities from which they were recorded are the 
the same as those reported here for N. oligospira. Thus, there is a distinct possibility that the ‥ mucronata reported from the area is actually referable to $\mathbb{N}$. oligospira. Good representatives of $\underline{N}$. macronata have been observed elsewhere in North America. Other species of this group occurring in various parts of the Americas include $\mathrm{N}$. microcarpa and $\mathrm{N}$. megacampa. The range of the former species overlaps that of N. 이gospira, especially in Central Anerica. Nitella megacarpa apparently does not occur within the range of $\underline{N}$. oligospira but its range does appear to merge somewhat with that of N. mucronata (mid-Atlantic coast). The available morphological data on representatives of this group from North, Central, and South America suggest that $\underline{\mathrm{N}}$. microcarpa (as described from South America) and $\underline{\mathrm{N}}$. megacarpa (as described from northeastern United States) represent the extremes; Whereas, N. oligospira and N. mucronata display intermediate characteristics. Nitella oligospira was observed only in still or flowing waters of limestone streams. The species appeared to be especially suited to completely open areas of clear flowing waters. Although water temperature varied somewhat $(20-30 \mathrm{C}), \mathrm{pH}(7.2-7.85)$, alkalinity $(162-315 \mathrm{mg} / \mathrm{I})$, and free carbon dioxide $(6.0-38.0 \mathrm{mg} / 1)$ were relatively consistent throughout the range. These conditions and the distribution of $\mathrm{N}$. oligospira being limited to southern regions of North America suggests that the species may be regarded as a tropical form. Of course, when habitat conditions are suitable and dispersal mechanisms are available the species can be expected to occur temporarily in more northern regions.

The Nitella gracilis species group is represented in North America by at least four previously described species, namely N. gracilis, N. intermedia, N. transilis, and $\mathbb{N}$. tenuissima. All of these species show a concentrated distribution in Northeastern United States. A single population of $\underline{\mathrm{N}}$. tenuissima was observed in the study area (San Iuis Potosi). Nitella tenuissima 
var. compacta has been reported from several localities in the area but this form is considered here to represent a taxon completely isolated from N. tenuissima (see below). The record of N. tenuissima from San Iuis Potosi represents a considerable extension of its range in North America. Specimens with morphological features nearly identical to N. tenuissima from the study area have been examined from Massachusetts and North Carolina. Other specimens referable to the species have been examined from midwestern United States.

Nitella tenuissima from the study area shows definite relationships to Taxon $\mathbf{A}$ of the $\underline{\mathrm{N}}$. gracilis species group which is described in the text, but the two forms display sufficiently contrasting morphological features to maintain them as separate species. Taxon $A$ is characterized by two morphological forms which can be attributed to differences in environmental conditions. One form is referable to $\mathbb{N}$. tenuissima var, compacta, whereas the other form is similar to specimens previously reported from the study area as $\mathrm{N}$. gracilis. It is presently concluded that Taxon A does not represent either of these species. Separation from N. tenuissima is based on morphological differences, whereas separation from $N_{\text {. gracilis }}$ is based on differences in morphology and chromosome numbers. A chromosome number of 18 has been reported on several occasions for N. gracilis. Taxon A shows 9 chromosomes exclusively. Taxon $A$ is presently considered to represent an infraspecific taxon of an unnamed species which also includes Taxon B. Taxon B is comprised of two forms which are distinguishable from one another both morphologically and cytologically. Neither of the forms is referable to previously described taxa. Although Taxon A and Taxon B are presently considered to represent a single species, it is quite clear that more data may reveal a complex made up of two or three separate species. The present treatment of these taxa is rather tentative but application of names to them at this time 
would serve only to complicate future work on the complex.

Taxon A and Taxon B can not be differentiated on the basis of their suitability to particular environmental conditions. Both taxa appear to be adapted to clear waters of limestone streams. These waters were characterized by temperatures of about $20 \mathrm{C}$, moderately alkaline $\mathrm{pH}$, medium to high alkalinity, and low to high free carbon dioxide. The variations in specimens of Taxon A which are referable to $\underline{H}$. tenuissima var. compacta at one extreme and to $\underline{N}_{\text {. gracilis }}$ at the other extreme correlate precisely with variations in flow conditions of the various streams. The former type which is characterized by short compacted branchlets was observed only in swiftly flowing waters. The type referable to ‥ gracilis (which is characterized by relatively long, thin, and spreading branchlets) was observed in still or slightly agitated ponded waters. Intermediate morphological types were observed in intermediate flow conditions.

Nitella hyalina is one of a few species of the genus which appears to be completely isolated from other species. This species is most closely related to members of the $\underline{N}_{0}$ gracilis species group but is readily distinguished from that group by its characteristic accessory branchlets. The general branchlet and gametangial characteristics of both groups are quite similar. Nitella hyalina possesses very consistent morphological features throughout its range in North America.

The present study revealed that $\mathbb{N}_{0}$ hyalina is much more common in North America than previously expected. The species was observed in a variety of habitats which were characterized by a wide variety of water conditions. This was especially evident with regard to temperature $(9.5-30.0 \mathrm{C})$, alkalinity $(22-315 \mathrm{mg} / \mathrm{I})$, total chlorides $(12-324 \mathrm{mg} / \mathrm{l})$, and free carbon dioxide $(0.0-$ $38.0 \mathrm{mg} / 1$ ). Consistencies among the various habitats included substrate types (usually containing silt or clay), water depth $(10-60 \mathrm{~cm})$, light conditions (always in open areas), and $\mathrm{pH}(7.1-8.5)$. The ability to withstand a wide range of environmental conditions probably accounts for 
Chara. - As a result of the numerous repeated recordings of the same specimens of Chara, it is impossible to determine the actual number of specimens previously reported from the study area. Members of the C. Nulgaris species group, and certain ones of the $\underline{\mathrm{C}}$. zerlanica species group (see appendix) which are presently omitted, represent over half of the total collections of Chara made during the present study. Species other than those of the above species groups known to occur in the study aree but not examined during the present study include $\underline{C}$. buckelliii, . canescens, and . . evoluta. These throe species have not been reported in the literature but were recently collected from several localities in New Moxico (Vernon Proctor, persconal commication). The number of specimens reported in this study for the rarious species more than doubles the number previously reported. Two species are reported for the first time, namely $\underline{\mathrm{C}}$. drouetii and $\underline{C}$. cienegaensis sp. nov.

Braun (1849) divided the genus Chare into two sections, the Haplostephanae and the Diplostephanae. Representatives of the former section are characterized by a single row of stipulodes, whereas those of the latter section are characterized by a double row of stipulodes. In revising the Characeae, Wood (1962) elevated these sections to subgeneric rank; and in doing so gave new names to these categories. According to Wood, the subgenus Chare is equivalent to section Diplostephanae and subgenus Charopsis is equivalent to section Haplostephanae. Species representing each of these subgenera were collected in the study area. Those treated in the present study include

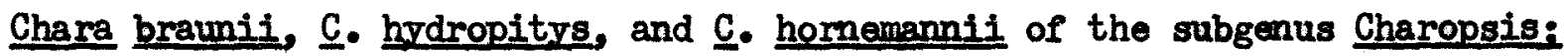
and $\underline{\text {. }}$ aspera, $\underline{\text { C. leptosperma, }}$. globularis, . sejumcta, . drouetii, and . . cienegaensis of the subgenus Chara. The limited number of species 
examined during this study prevents making conclusions regarding their interrelationships. As was the case with species of Nitella, the species of Chare are discussed from the standpoint of relationships within particular species groups. The above species comprise four species groups; however, one group (‥ braunif) is characterized by only a single species in North America.

Chare braunif is a cosmopolitan species not closely related to any other species occurring in North America. Its closest relatives are $\underline{C}$. corellina and $\underline{C}$. australis, both of which are limited to Australasian regions. The Chara braunif complex is comprised of several infraspecific taxa, three of which are reported here. These include f. nori-mexicana, f. gracilis, and f. gchweinitzif. Chara braunif fl gracilis, as defined here, represents a new interpretation of $\underline{C}$. coronata var. gracilis (Allen, 1882) and $\underline{\mathrm{C}}$. pallida (Robinson, 1906). This treatment is a further separation of the species at the forma level than that proposed by Wood (1962). The latter author included var. gracilis and . pallida under C. bramif f. novi-mexicana. The specimens utilized by Robinson (1906) to establish C. pallida are the same as those described as C. coronata var. gracilis by Allen (1882). Iikewise, the specimens typifying C. coronata f. novi-mexicana (Braun and Nordstedt, 1882) are the same as those described as $\underline{C}$. coronata $f$. tenera (credited to Braun by Allen, 1882). Results of morphological study of specimens collected during this study reveal that the two forms are distinct from one another. They are presently included as formae in concurrence with Wood's treatment. Chara braunil f. schweinitzil is easily distinguished from the above on the basis of several morphological features. Although these three morphological types are reported as formae, it is quite clear that this complex is made up of several more or less distinct taxa and 
when they are more fully understood higher infraspecific or even specific rank may be required.

Chara braunil occurs throughout North America in a wide variety of habitats. The species is found primarily in lowland aress in regions of higher latitude, but in more southern regions the species appears to be limited to areas of higher elevation. In the study area the species was observed in swift streams, lakes, quarry ponds, and on one occasion in a spring-fed concrete tank. These habitats usually were characterized by sandy substrates and cool waters $(20.0-25.0 \mathrm{C})$. These conditions appear to be the most critical with regard to maintenance of significant populations. Considerable variation was observed in light conditions and water chemistry ( $\mathrm{pH} 7.3-10.0$, alkalinity $42-270 \mathrm{mg} / 1$, free carbon dioxide $0.0-26.0 \mathrm{mg} / \mathrm{l}$ ). The ability to withstand such extremes probably accounts for the cosmopolitan occurrence of the species.

Chara hydropitys and $\underline{C}$. hornemannii are presently included in the C. fibrosa species group. However, these species appear to be only distantly related. Other species occurring in North America which can doubtlessly be placed in this species group include $\underline{\mathrm{C}}$. flbrose and $\underline{\mathrm{C}}$. keukensis. The former species is clearly defined by $\underline{C}$. keukensis displays marked similarities to $\underline{\mathrm{C}}$. hydropitys. In fact, examination of specimens from Texas, Arkansas, Missouri, Indiana, and Michigan revealed a somewhat variable but intergrading series of morphological forms ranging from typical C. hydropitys in the south to forms similar to $\underline{\mathrm{C}}$. kevkensis in the northern localities. This intergradation was especially evident in respect to branchlet cortication and number of branchlet segments. Specimens from Texas, Arkansas, and Missouri were characterized by 6-8 segments of which (1-) $2(-3)$ were corticated, whereas specimens from southern Indiana displayed 5-6 segments usually with only one corticated, 
and those from Michigan were characterized by 4-5 segments of which one was rarely corticated. Several of the Michigan specimens displayed a complete lack of branchlet cortex which is the principal feature characterizing $\underline{C}$. keukensis. The known geographical range of $\underline{C}$. keukensis includes portions of New York, Ontario, Indiana, and IIlinois. This range overlaps the northern limits of the $\underline{C}$. hydropitys range. Chara keukensis may represent only a growth form of $\underline{\mathrm{C}}$. hydropitrs which is peculiar to certain northern environments or it may actually represent a distinct infraspecific taxon possibly distinguishable at the subspecies level.

The habitats found to support $\underline{C}$. hydropitys varied considerably with regard to size, substrate type, and water depth. The species occurred as scattered tufts in very shallow waters and in some instances on saturated soil at the edges of rather large bodies of water. The species occurred as luxuriant stands at depths of about 1 meter in small bodies of water in Texas, Arkansas, and Missouri localities. As a result of the shallow conditions in the northern localities light and temperature conditions were similar to those of the deeper southern habitats. Chemical conditions of the various habitats were relatively uniform, being characterized by moderately alkaline $\mathrm{pH}$, a low to medium alkalinity, a low chloride content, and on occasion a complete lack of free carbon dioxide.

Chara homemannif is clearly distinguishable from $\underline{\text { C. hydropitys }}$ and other members of the $\underline{C}$. fibrosa species group. The species is characterized by a very robust habit and attains heights of over 2 meters, whereas other members of the $\underline{C}$. fibrosa species group are quite small and delicate. Specimens from all populations of $\underline{C}$. hornemannif examined during this study displayed 28 chromosomes exclusively. Chara hydropitys is characterized by a chromosome number of $I_{4}$ and C. fibrosa from coastal 
regions of North Carolina is characterized by a chromosome number of 42 .

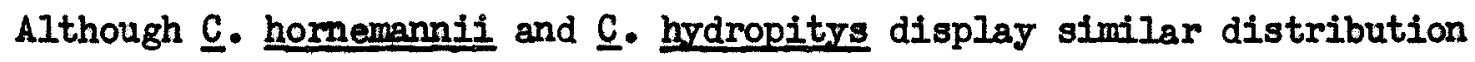
patterns the species occupy completely different habitats. This is especially evident in respect to the brackish conditions and wide range of temperature (14.0-37.0 C) and $\mathrm{pH}(7.2-9.8)$ of the waters supporting C. homemannif. This is the only species of Chare examined from the study area which can be classified as a true halophyte.

The Chara globularis species group is represented in the study area by three species, $\underline{C}$. aspera, $\underline{\mathrm{C}}$. leptosperma, and $\underline{\mathrm{C}}$. globularis. Chara aspera has been observed only rarely in the area, primarily in regions of high salinity other than coastal areas. It is quite probable, however, that the species is abundant and widespread in the area because many habitats characteristic of those found to support the species were not examined. Chara aspera is easily distinguished from other members of the species group by its dioecious condition and distinctive spiny appearance. The species is also distinguishable cytologically, in that it is the only species of the group displaying a chromosome number of $\mathrm{H}_{4}$.

Chara aspera was found in abundance in still and swiftly flowing waters but it reached greatest size and sexual maturity in flowing waters. The species flourished in highly alkaline and brackish waters, and appeared to be particularly adapted to cool waters with maximum light penetration.

The specimens of Chara leptosperma reported here represent the only records of the species other than that of the type specimens from Vera Cruz, Mexico. Thus, the present records from southern Arizona extend the range of the species considerably. This species is distinguished from $\underline{\text { C. }}$ aspera by its monoecious condition, reduced spine-cells, 
golden-brown oospores, and chromosome number of 28. Chara leptosperma and $\underline{\mathrm{C}}$. globularis are similar in respect to sexual condition, general habit, and chromosome number but they are clearly distinguishable on the basis of stipulode and bract-cell development, and oospore character. Chara leptosperma displays well-developed stipulodes and bract-cells and is characterized by a distinctly marked oospore, whereas C. globularis displays very reduced stipulodes and bract-cells and is characterized by dark brown to black oospores. These characters are very consistent in both species.

The two habitats found to support $\underline{C}$. leptosperma were simflar in that both were small bodies of water derived from spring sources. They were also basically similar in respect to alkalinity, $\mathrm{pH}$, temperature, and light conditions. The waters differed primarily in amounts of total chlorides and free carbon dioxide $(18.5-383 \mathrm{mg} / 1$ and $0.0-20.0 \mathrm{mg} / \mathrm{l}$, respectively).

Chara globularis was observed in abundance throughout areas of higher elevation in the study area. All specimens of this species observed in the area are referable to a single infraspecific taxon, c. globularis var. capillacea. These specimens were consistent with regard to axis cortication, spine-cells, stipulodes, bracteoles, and branchlet number. Variations in vegetative morphology were limited to height of plants and number of branchlet segments. These characters were relatively uniform within particular populations. It is presently concluded that this variation resulted primarily from differences in environmental conditions. Considerable variation in oogonia and oospores was observed between specimens from different populations and between specimens from single populations. These variations were observed in size and shape of the oogonia and associated coronulae, and size, shape, and cage character of the oospores. Five rather consistent groups were 
differentiated on the basis of these characters. Representatives of these groups were obtained from separate individuals of single populations as well as from different populations. It is presently concluded that these groups represent five distinct morphs which are controlled genetically rather than by differences in environmental conditions. Thus, ‥ globularis var. capillacea actually displays true polymorphic characters. Such a condition has been attributed to many other species of Chara but the term has been wrongly used in that it has been used to refer to polytypic conditions.

The results obtained from habitats supporting $\underline{\mathrm{C}}$. globularis in the study area indicate that the species is capable of inhabiting a rather narrow range of environmental conditions. The species appears to be particularly adapted to cool, sandy-bottomed, and well-lighted bodies of quiet water. The species was rarely observed in swift waters, and under such conditions the species showed no signs of sexual maturity. The waters were characterized by a moderate to high alkalinity, pH, ranging from 7.3-10.0 (usually above 8.2), low chlorides, and usually a complete lack of free carbon dioxide.

The Chara zexlanica species group is represented in the present study by only those species characterized by sejoined gametangia, namely

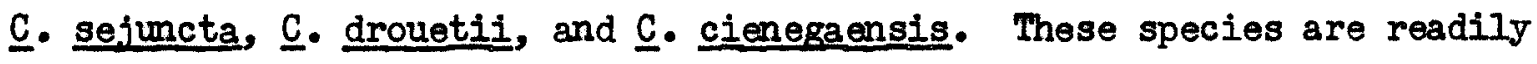
distinguished morphologically. Some of the characters which reveal distinct differences include general habit, number and length of branchlets, branchlet segment number and degree of cortication, degree of spine-cell development, axis cortication (tylacanthous in C. cienegaensis), and size and shape of gametangia and oospores. It is presently concluded that these species represent three independent evolutionary lines with their closest relatives being found among the members of the species group 
characterized by conjoined gametangia. All three species are characterized by a chromosome number of $\mathrm{H}_{4}$ and an antheridial plate number of 8 . Morphological counterparts of $\underline{C}$. sefuncta and $\underline{C}$. cienegaensis which display conjoined gametangia are characterized by a chromosome number of 28 and an antheridial plate number of 4. A similar counterpart of C. drouetif has not been reported. Further relationships between these three species can not be discussed until a complete study is made of the conjoined nembers of the species group.

Chara sefuncta is widely distributed in North and South America but it has not been found in great abundance in the study area. Ecological observations on the species are presently reported from localities in North Carolina, Kentucky, Tennessee, Kansas, and Texas. In these areas the species showed a distinct preference for shallow, warm, and open waters characterized by low alkalinity and moderately acid to highly alkaline pH. Systematic observations on 2 Kentucky ponds revealed rapid deterioration of large populations of the species following marked decreases in water temperature. Further evidence suggesting intolerance to low temperature is that specimens obtained from a Kentucky pond with water temperature of $11.0 \mathrm{C}$ displayed numerous aberrant mitotic divisions in their antheridia.

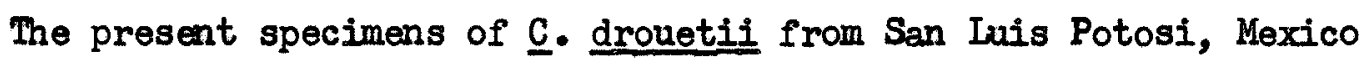
represent the only record of the species other than from the type locality in Ceara, Brazil. The species was first reported from "shallow water of a pond at base of dunes." The present specimens occurred as dense tufts in shallow waters of a ponded area in a slowly flowing limestone stream. The water was characterized by the following conditions at the time of collection: temperature $30 \mathrm{C}, \mathrm{pH} 7.85$, alkalinity 193 $\mathrm{mg} / \mathrm{l}$, and free carbon dioxide about $5 \mathrm{mg} / 1$. 
Chara cienegaensis was observed only in the intermontane besin of Cuatro Cienegas, Coahuila, Mexico. The species formed extensive beds in a small lake and rather large tufts in swiftly flowing canals. Both habitats were characterized by cool waters and marly substrates. Istimates of alkalinity, $\mathrm{pH}$, etc. were not made on these habitats but most of the waters in the same general area displayed high alkalinity and an alkaline $\mathrm{pH}$. 


\section{LITERATURE CIMED}

Agardh, C. A. 1824. Systema Algarum. Irund.

Allen, G. 0. 1951. Notes on charophytes from British Columbia. Proc. Iinn. Soc. Iondon 162 (2):148-152.

- 1954. An annotated key to the Nitelleae of North America. Bull. Torrey Bot. Club 81 (1):35-60.

Sudamericana Bot. $I(3): 87-91$.

Allen, T. F. 1871. Characeae. Bull. Torrey Bot. Club 2(3):9-10.

- 1880. The Characea of America. Part 1:1-8, Part 2:9-14. Boston.

- 1882. Observations on some American forms of Chara coronata. Am. Nat. $16(5): 358-369$.

-18 1888. The Characeae of America. Part 1:1-64. New York.

m. 1892. Notes on some Characeae. Bull. Torrey Bot. Club $19(7): 230$.

1893a. Notes on New Characeae. Ibid. 20(3):119-120.

-1893b. Notes on some Characeae. Ibid. 20(6):258.

- 1894a. Remarks on Chara gymopus A. Br., with descriptions of new species of Chara and Nitella. Ibid. 21(4):162-167.

- 1894b. The Characeae of America. Part 2, Fasc. 2:9-17, New York.

- 1894c. Note on Chara sejuncta A. Br. BuIl. Torrey Bot. Club 21(12):526.

- - 1896a. Nitella subspicata sp. nov. Bull. Torrey Bot. Club $23(1): 6-7$.

-1896b. New species of Nitella belonging to the monoecious acuminata group, with review of the allied species. Bull. Torrey Bot. Club 23(12):534-536. 
-2.- 1896c. The Characeae of America Part 2, Fasc. 3:19-28.

New York.

-_ 1900. Three new Charas from California. Bull. Torrey Bot. Club 27(6):299-304.

Bischoff, G. W. 1828. DHe kryptogamischen gewächse, mit besonderer Berücksichtigung der flora Deutschland und der Schweiz. Vol. I. Die Chareen und Equiseteen. Nümberg.

Braun, A. 1834. Esquisse monographique du genre Chara. Ann. Sci. Nat., Bot., Ser. 2, 1:349-357.

-1845. (Additional notes of the North American Charae) In G. Bngelmann and A. Gray, Plantae Iindheimerianae. Boston J. Nat. Hist. $5(2): 264$.

- 1849. Uebersicht der Schweizerischen Characeen. Ein Beitrag zur Flora der Schweiz. Neue Denkschr. Schweiz. Ges. Naturw. $10(3): 1-23$.

-1859. Ubersicht der Characeen aus Columbien und Guyana. Monatsber. Kon. Akad. Wiss. Berlin, 23, 1858:349-368. Berlin.

- - and C.F. O. Nordstedt. 1882. Fragmente einer Monographie der Characeen. Abh。K. Akad. Wiss. Berlin, 1882:1-211.

Britton, N. L. 1889. Catalogue of plants found in New Jersey. Geol. Survey of New Jersey, Final Rep. St. Geol. 2:356, 357. Trenton. -, and C. F. Millspaugh. 1920. The Bahama Flora. New York. Cole, G. A. 1963. The American Southwest and Middle America. In Limmology of North America, ed. by D. G. Frey. Univ. Wisconsin Press, Madison.

-_-, and M. Whiteside. 1965. An ecological reconnaissance of Quitobaquito Spring, Arizona. J. Arizona Acad. Sci. 3(3):159-163. 
Daily, F. K. 1944. The Characeae of Nebraska. Butler Univ. Bot. Stud. $6: 149-171$.

-1953. The Characea of Indiana. Tbid. 11:5-49.

-1958. Some observations on the occurrence and distribution of Characeae in Indiana. Indiana Acad. Sci. 68:95-107.

- - and W. Kiener. 1956. The Characeae of Nebraska-additions and changes. Butler Univ. Bot. Stud. 13(1):36-46.

- and C. L. Porter. 1961. A key and annotations for some Characeae collected in Wyoming. Ibid. $\mathcal{H}_{4}(1): 29-37$.

Dame, L. L., and F. S. Collins. 1888. Flora of Middlesex County, Massachusetts. Malden.

DeCandolle, A. P. 1915. In J. B. A. P. De Lamarck and A. P. DeCandolle. Flore Francaise. Vol. 5(6), ed. 3. Paris.

Desvaux, A. N. 1809. Essai sur la géographie-botanique du Haut-Poitou (Departemente de la Vienne). J. de Bot. 2:290-318.

Fritsch, F. E. 1935. The Structure and Reproduction of the Algae. Vol. 1. Cambridge。

Geiling, W. T., and L. A. Krumbolz. 1964. A limological survey of sinkhole ponds in the vicinity of Doe Run, Meade County, Kentucky. Trans. Kentucky Acad. Sci. 24(3-4):37-80.

Gillet, C. 1959. Nombres chromosomiques de plusieurs especes de Charophycées (generes Nitella et Chara). Rev. Cyt. et Biol. Véget. 3:229-234.

Gmelin, C. C. 1826. Flora Badensis Alsatica. Vol. 4. Carlsruhe. Griffin, D. G. 1963. Variation in oospores of six species of Chara. Bull. Torrey Bot. Club 90(6):400-402.

-, and V.W. Proctor. 1964. A population study of Chara zeylanica in Texas, Oklahoma, and New Mexico. Am。 J. Bot. 5I(2):130-134. 
Groves, H., and J. Groves. 1911. Characeae. In I. Urban, Symbolae Antillanae, seu fundamenta Florae Indiae Occidentalis, $7(2): 30-$ 44. Iipsiae.

Groves, J. 1924. Notes on Indian Charophyta. J. Iinn. Soc. Bot. London. $46: 359-376$.

- 1935. The primary divisions of the genus Nite12a. J. Bot. $73: 46-49$

-, and G. R. Bullock-Webster. 1920. The British Charophyta. Vo1. I. Nitelleae:1-141. Ray Society, Iondon.

Guerlesquin, M. 1961. Contribution à 1'étude chromosomique des Charophycées diEurope occidentale et d'Afrique du nord. Rev. gen. Bot. $68: 360-372$.

-1963. Contribution a 1étude chromosomique des Charophycées d'Burope occidentale et d'Afrique du nord. II. Rev. Gen. Bot. $70: 355-370$

Halsted, B. D. 1879. Classification and description of the American species of Characeae. Proc. Boston Soc. Nat. Hist. 20:169-190. Hasslow, 0. J. 1940. Einige Characeenbestimmungen. III. Bot. Not. $1940(3): 287-288$.

Hevly, R. H. 1961. Notes on aquatic non-flowering plants of northerm Arizona and adjoining regions. Plateau 33:115-119.

Horn af Rantzien, R. 1950. Charophyta reported from Iatin America. Arkiv. Bot., Ser. 2, I(8):355-411.

-1959. Comparative studies of some modern, Cenozoic, and Mesozoic Charophyte fructifications. Stockholm Contr. Geol. 5(1):1-17. Stockholm.

Hotchkiss, A. T. 1958. Some chromosome numbers in Kentucky Characeae. Trans. Kentucky Acad. Sci. $19(1-2): 14-18$. 
-2. 1963. A first report of chromosome number in the genus Iychnothamus (Rupr.) Leonh, and comparisons with the other charophyte genera. Proc. Iinn. Soc. N.S.W. 88:368-372.

-1. 1965. Chromosome numbers in Characeae from the south Pacific. Pacific Sci. 19(1):31-37.

Imahori, K., and T. Kato. 1961. Notes on chromosome numbers of charophytes in Fukui Prefecture, Japan (I). Sci. Rep. No. 10. Osaka Univ.

Kasaki, H. 1964. The Charophyta from the lakes of Japan. Jour. Hattori Bot. Lab. No. 27:217-314.

Kuttzing, F. T. 1843. Phycologia Generalis, oder Anatomie, Physiologie, und Systemkunde der Tange. Leipzig.

-1849. Species Algarum. Iipsiae.

- - k857. Tabulae Phycologicae, oder Abbildunger der Tange. Nordhausen.

Linnaeus, C. 1753. Species Plantarum, 2. Stockholm. Loiseleur-Deslongchamp, J. L. A. 1810. Notice sur les Plantes á ajouter á la Flore de France. Paris.

Mayr, E. 1963. Animal Species and Evolution. Belknap Press. Massachusetts.

McCleary, J. A. 1957. Notes on Arizona plants. South Western Nat. $2(4): 152-154$.

Moore, E. W. 1939. Graphic determination of carbon dioxide and three forms of alkalinity. J. Am. Water Works Assn. 3I(I):51-66. Muenscher, W. C. 1933. Aquatic vegetation of the upper Hudson watershed. In Biological Survey (1932), No. 7. New York State Conserv. Dept., Albany. Ann. Rep. (1932), Suppl. 22:238.

Nordstedt, 0. 1889. De algis et Characeis. Iunds Univ. Arsskr. 25:1-41. Lund. 
Olsen, S. 1944. Danish Charophyta, chorological, ecological, and biological investigations. Kongel. Danske Vidensk. Selskab. Biol. Skrifter 3:1-240.

Ophel, I. L. 1952. The genus Chara in Oklahoma. Oklahoma Acad. ScI. 33:179-183.

Peck, R. B. 1957. North American Mesoroic Charophyta. U. S. Geol. Survey Prof. Pap. 294-A:1-44. Wash., D. C.

Pieters, A. J. 1901. The plants of western Iake Erie, with observations on their distribution. Bull. U. S. Fish Corm. 21:57-59.

Prescott, G. W. 1931. Iowa Algae. Univ. Iowa Stud. 13(6):1-235.

-1951. Algae of the Western Great Lakes. Cranbrook Inst. Sci. Bull. No. 31:1-977.

Proctor, V. W. 1961. Batophora from central New Mexico. Phycologia $1(4): 160-163$.

Reichenbach, H. G. I. 1829. In Mössler's Handbuch der Gewachskunde. ed. 2. Altona.

Robinson, C. B. 1906. The Chareae of North America. Bull. New York Bot. Garden 4(13):244-308.

Sarma, Y. S. R. K. and M. Khan. 1964. Chromosome numbers in some Indian species of Nitella. Chromosoma 15(3):246-247.

Sasaki, M. 1960. Cytological studies in Charophyta, with special reference to synchronous mitosis in antheridial filaments. St. Paul's Rev. Sci. Nat. Sci. 8-9:1-45.

Sato, D. 1959. The prokaryotype and phylogeny in plants. Sci. Pap. Coll. Gen. Educ. Univ. Tokyo. 9:316.

Smith, G. M. 1950. The Fresh-Water Algae of the United States. MeGraw-Hill, New York.

- 1955. Cryptogamic Botany. Vol. I. Algae and Fungi. McGrawHill, New York. 


\section{$-225-$}

Stewart, L. M. 1937. Studies in the life history of Nitelle hyalina

Agardh. J. Elisha Mitchell Sci. Soc. 53:173-190.

Taylor, W. R. 1921. Additions to the flora of Mount Desert, Maine. Rhodora 23(266):65-68.

Thuillier, J. L. 1799. Ia Flore des Environs de Paris, on distribution méthodique des plantes qui $\mathrm{y}$ croissent Naturellement. Paris. TindaII, D. R., and T. Sawa. 1964. Chromosomes of the Characeae of the Woods Hole (Massachusetts) region. Am. J. Bot. 51(9):943-949. - - and W. I. Minckley. 1964. An integrated application of three kinds of sampling techniques to stream limnology. Limmol. 0ceanogr. $9(2): 270-272$.

Wallman, J. 1853. Försök till en systematisk uppstalinhing av vaxtfamiljen Characeae. Stockholm.

Williams, R. S. 1892. The flora of a Montana Pond. Bull. Torrey Bot. Club 19:192-194.

Willdenow, C. L. 1809. Funf neue Pflanzen Deutschland. Ges. Naturf. Freunde Berlin Mag. 3:296-298.

Wood, R. D. 1947. Characeae of the Put-in-Bay Region of Lake Brie (Ohio). Ohio J. Sci. 47:240-258.

- A review of the genus Nitella (Characeae) of North America. Farlowia 3:331-398.

--.. The Characeae of the Woods Hole region, Massachusetts. Biol. Bull. 96(2): 179-203.

-1954. The Characeae of Iake Mattamuskeet, North Carolina.

J. Blisha Mitchell Sci. Soc. 70:60-74.

-1.. 1962. New combinations and taxa in the revision of the Characeae. Taxon 11:7-25.

-2. 1963. Characeae of Samoa. Bull. Torrey Bot. Club 90(4):225-229. 
-_-1964. A synopsis of the Characeae. Ibid. 91(1):35-46.

--, and W. C. Muenscher. 1956. The Characeae of the state of New York. Mem. Comell Univ. Agr. Exp. Sta., No. 338:1-77.

Characeae. Bull. Torrey Bot. Club 86(3):172-183.

--, and -. 1964. Monograph of the Characeae. Vol. II. V. von J. Cramer, Germany.

-, and - 1965. Monograph of the Characeae. Vol. I. V. von J. Cramer, Germany.

Zaneveld, J. S. 1940. The Charophyta of Malaysia and adjacent countries. Blumes 4:1-224.

-1 1942. Some notes on Charophyta collected in the Netherlands West Indies, North Venezuela and Columbia. Rec. Trav. Bot. Neer1. 38:141-146. Amsterdam. 


\section{APPENDIX}

\section{CHARA VUIGARIS SPECIES GROUP}

This species group constitutes one of the most baffling taxonomic problems of the Characeae. Several species comprise the group but they are not always easily distinguishable from one another on the basis of current specific criteria. As mentioned above the various species of this group are not treated separately. However, my inclusion of the species under one group name should not be construed as meaning that I concur with Wood's (1962) treatment of the group as a single species. Rather, the numerous collections of species of this group from the study area and the extremely variable morphological systems of most of them constitute a problem which is beyond the scope of the present study. Chromosome numbers, general ecology and distribution, and tentative conclusions regarding taxonomy and relationships of specimens of this group collected in the study area are included in Table 30. Final conclusions regarding the group will be presented in a separate paper.

\section{CHARA ZEYLANICA SPECIES GROUP (excluding sejoined types)}

The Chara zeylanica species group is comprised of several more or less distinct forms which have been classified at various levels ranging from species to forma (Robinson, 1906; H. and J. Groves, 1911). In the most recent monographic treatment of the Characeae (Wood, 1962; Wood and Imahori, 1964, 1965) all forms of this group (including C. sejuncta, C. drouetii, all forms referable to $\underline{C}$. zevlanica, and a very distinct uncorticated species, ‥ brittonii $A l l e n$ ex Rob.) were regarded as a single species. Griffin and Proctor (1964) demonstrated that at least 2 distinct taxa can be distinguished among members of the group with 
Table 30. Tentative list of probable species of the Chara vulgaris species group collected in the study area; including possible relationships, chromosome numbers, and general ecology and distribution.

SPECIES

C. hispida-like Kütz.

C. Echaffnerif (A. Br.) Rob.

c. kleneri Daily

C. contraria A. Br. ex Kütz.

C. inconnexa-like Allen

C. contraria-typical

C. excelsa-like Allen

C. vulgaris L.

Undetermined taxon

(delicate)

C. vulgaris-typical

CHROMOSOME NO.

42

28

28

$28,42,56$

28,42

28

14

\section{BCOLOGY AND DISTRIBUTIOR}

Observed only in quiet brackish waters in New Mexico.

Rare but observed in quiet alkaline waters throughout the area.

Observed only in quiet neutral waters in Kansas.

Typical inhabitor of cool, flowing, alkaline waters in desert areas.

Dbiquitous, abundant throughout the area.

Typical inhabitor of warm intermittent desert pools.

Both characteristic of cool flowing waters in highland areas of Oklahoma and Arizona. 
conjoined gametangia but did not suggest the taxonomic level at wich the taxa should be ranked. Their findings indicate that specific status should be granted these forms. Both authors are currently carrying out experimental study on several members of the group obtained primarily from the present study area.

Fifty-one collections of this group were made during the present study from southern Texas, southern Arizona, Tamaulipas, San Iuis Potosi, Vera Cruz, Coahuila, Chihuahua, and Sinaloa. All representatives of the group appear to prefer warm alkaline waters. Some occur in brackish waters, whereas others appear to be limited to fresh waters. Preliminary observations on the specimens reveal a marked consistency in certain types. Morphological types which appear to represent distinct species include those referable to the following names: Chara zeylanica Klein ex Wild., C. elegans (A. Br.) Rob., and C. inconstans A. Br. Final conclusions regarding these forms must await the outcome of the experimental studies mentioned above. 